\title{
NEUROPLASTICIDADE INDUZIDA PELO EXERCÍcIO: EFEITOS SOBRE O HIPOCAMPO E REGIÕES MOTORAS DO ENCÉFALO DE RATOS
}

Tese apresentada ao Programa de PósGraduação em Fisiologia Humana do Instituto de Ciências Biomédicas da Universidade de São Paulo, para obtenção do Título de Doutor em Ciências. 
ANA FRANCISCA BARROS FERREIRA

\section{NEUROPLASTICIDADE INDUZIDA PELO EXERCÍCIO: EFEITOS SOBRE O HIPOCAMPO E REGIÕES MOTORAS DO ENCÉFALO DE RATOS}

Tese apresentada ao Programa de PósGraduação em Fisiologia Humana do Instituto de Ciências Biomédicas da Universidade de São Paulo, para obtenção do Título de Doutor em Ciências.

Área de Concentração: Fisiologia Humana

Orientador:

Prof. Dr. Luiz Roberto Giorgetti de Britto

Versão Corrigida

São Paulo

2011 
DADOS DE CATALOGAÇÃO NA PUBLICAÇÃO (CIP)

Serviço de Biblioteca e Informação Biomédica do

Instituto de Ciências Biomédicas da Universidade de São Paulo

reprodução não autorizada pelo autor

\section{Ferreira, Ana Francisca Barros.}

Neuroplasticidade induzida pelo exercício: efeitos sobre o hipocampo e regiões motoras do encéfalo de ratos / Ana Francisca Barros Ferreira. -- São Paulo, 2011.

Orientador: Luiz Roberto Giorgetti de Britto.

Tese (Doutorado) - Universidade de São Paulo. Instituto de Ciências Biomédicas. Departamento de Fisiologia e Biofísica. Área de concentração: Fisiologia Humana. Linha de pesquisa: Comunicação celular no sistema nervoso.

Versão do título para o inglês: Exercise-induced neuroplasticity: effects on the hippocampus and motor regions of the rat brain.

Descritores: 1. Exercício físico 2. Plasticidade neuronal 3. Córtex motor 4. Cerebelo 5. Cálcio 6. Endotelinas I. Britto, Luiz Roberto Giorgetti de II. Universidade de São Paulo. Instituto de Ciências Biomédicas. Programa de Pós-Graduação em Fisiologia e Biofísica. III. Título. 


\section{UNIVERSIDADE DE SÃO PAULO \\ INSTITUTO DE CIÊNCIAS BIOMÉDICAS}

Candidato(a):

Ana Francisca Barros Ferreira.

Título da Tese:

Neuroplasticidade induzida pelo exercício: efeitos sobre o hipocampo e regiões motoras do encéfalo de ratos.

Orientador(a): $\quad$ Luiz Roberto Giorgetti de Britto.

A Comissão Julgadora dos trabalhos de Defesa da Tese de Doutorado, em sessão pública realizada a considerou

\section{( ) Aprovado(a) ( ) Reprovado(a)}

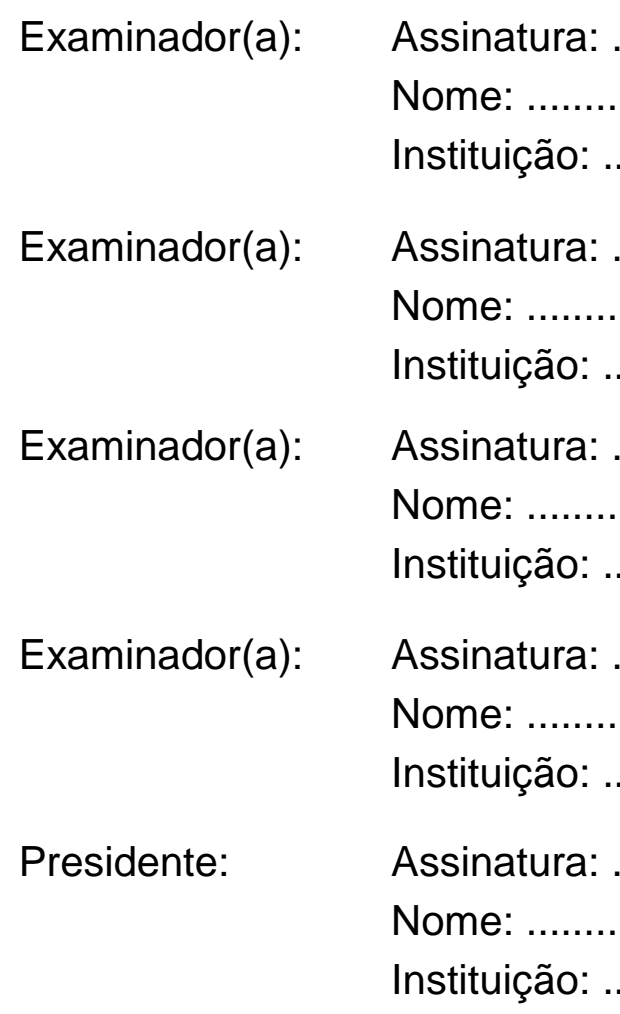




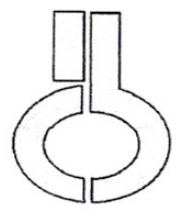

UNIVERSIDADE DE SÃO PAULO INSTITUTO DE CIÊNCIAS BIOMÉDICAS

Cidade Universitária "Armando de Salles Oliveira"

Av. Prof. Lineu Prestes, 2415 - CEP. $05508-000$ Săo Paulo, SP - Brasil

Telefone :(55) (011) 3091.7733 - telefax : (55) (011) 3091.7438

e-mail: cep@icb.usp.br

\section{Certificado}

Certificamos que o protocolo registrado sob $n^{\circ} 013$ nas fls. 29 do livro 2 para uso de animais em experimentação, sob a responsabilidade do(a) Prof.(a) Dr.(a) Luiz Roberto G. de Britto, Coordenador(a) da Linha de Pesquisa "Efeitos plásticos agudos do exercício e da eletroestimulação no encéfalo de ratos" do qual participou(aram) o(s) alunos Ana Francisca Barros Ferreira, está de acordo com os Princípios Éticos de Experimentação Animal adotado pelo Colégio Brasileiro de Experimentação Animal (COBEA) e foi aprovado pela COMISSÃO DE ÉTICA EM EXPERIMENTAÇÃO ANIMAL (CEEA) em 23.02.2006.

São Paulo, 06 de março de 2006.

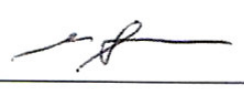

Profa. Dra. Marília C.L.Seelaender Coordenadora -CEEA - ICB/USP

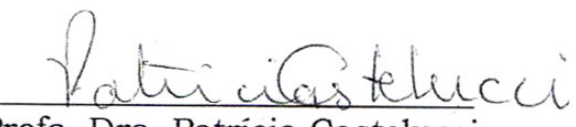

Profa. Dra. Patrícia Castelucci Secretária Suplente CEEA - ICB/USP 
Aos meus pais Luiz e Adélia, à minha irmã clarissa aos meus avóse, principalmente, ao carlos, pelo amor incondicional, dedicação, companheirismo, apoio... enfim... por existirem e serem parte da minha vida! 


\section{AGRADECIMENTOS}

Aos meus pais pelo amor, incentivo, apoío e por sempre fazerem tudo que podem $e$ que não podem para me proporcionar tudo de melhor na vida sem pedir nada em troca.

A minha querida irmãzinha clarissa, pelo amor, palavras amigas e por estar sempre perto mesmo estando longe.

Ao carlos, men maridinho, amigo, companheíro de todas as horas, pelo amor $e$ incentivo, sem ele eu não tería chegado até aquí...

Às minhas avós e ao meu avô pelo amor, carinho, apoío, conselhos, broncas, lições de vida, e porter me dado pais maravilhosos.

Ao Prof. Britto por ter me permítido seguir este caminho, abrindo as portas para mim, pelo seu inestimável apoío, paciência, inúmeras correções, conselhos e ensinamentos.

A Profa. Andréa por estar sempre disponivel para nos ajudar, pelo carinho, contribuições e sugestões.

A Profa. Jessica Fillosa por todo o apoio, por me receber e acolher, e por seus constantes ensinamentos.

Aos professores Rui curi e Francesco Langone pelo apoí, incentivo e sugestões.

Aos professores, técnicos e alunos do departamento de Fisiología e Biofisica, e também dos departamentos de Farmacología e Anatomia por estarem sempre dispostos a ajudar.

Ao Adílson, não sei por onde começar, mas um amigo, companheiro, prestatívo, sempre disposto, sorrindo on gritando, pronto para fazer os problemas desaparecerem! obrigada por tudo!

A Erika, Taisa e Gabi, amigonas do peito que sempre sabem o que dizer para me fazer uma melhor pessoa e pesquisadora e que nunca me deixam na mão.

À carol por todas as conversas, ajuda e belo trabalho em equipe!

Ao Dani, o nosso anjo salvador para todos os momentos.

A Maru e Ro (Marucia Chacur e Rosana Pagano), minhas queridas amiguinhas, que ja seguiram seus caminhos tão sonhados, mas que estão sempre presentes ajudando no que podem, e aos seus alunos Dani, Mi, Fábio, Pri, Joyce... 
A Rhows e ao Alê (Rhowena Matos e Alexandre Kihara) que também já seguiram seus caminhos, mas que foram muito importantes para os meus primeiros passos no lab. obrigada por todas as conversas, sugestões, críticas, palavras amigas...

A Alice por estar sempre sorrindo e nos puxando para frente com seu ritmo alucinante!

Ao Mauro por sua calma e por estar sempre por perto para tírar toda e qualquer dúvida, e com paciência!

Ao caio, geniozinho ambulante, sempre sorridente, de bem com a vida e com uma ótima pergunta e/ou resposta.

Aos queridos amigos (alunos, ex-alunos, agregados) dos laboratórios do Prof. Britto e da Profa. Andréa por tornarem meus dias muito mais felizes e iluminados: Kallene, Marina, cecília, Vívian, Angélica, vera, Rafaela, Renata, carol Alencar, Paula, Guilherme, carol, Rodrigo, Luciana, Monalisa, samuel, Natália, Ivana, André, Danílo, Raquel...

Aos mens professores, orientadores, amigos e colegas do Medical college of Georgia: Dr. Javier Stern, Dra. Rita Tostes, Dra. Adviye Ergul, Dr. Clinton Webb, Vinicia, Haruki, Aleshia, Mrs. Beverly Tarver, Nick, Wagner, Tiffany, Sookjin, Krishna, Ki Jung, Evgeniy, Fernanda, Victor, Fernando, Zidonia, Fernandinho, Nubia, Safia, vera, Roshini, Edson, Brandi, Hicham, Kyan, Quênia, Domítila, María Alicía...

Ao pessoal das secretarias, da biblioteca, funcionarios do departamento e ICB: Zé, Leíla, claudia, Monica, Eva, Paloma, Sidney, Teca, Maristela, Aninha...

Às minhas queridas amigas de infância, carol e Fernanda, por mílhões de momentos de alegria e amizade.

Às minhas amigas da faculdade, em especial à Débora, cecílía e Bruna, que pela distância eu quase nunca vejo, mas sempre farão parte da minha vida.

Aos meus lindos cãezinhos por me ensinarem um novo significado da palavra amor.

A FAPESP, CNPq e CAPES pelo apoío financeiro.

A DEUS por tudo que esta à minha volta e por colocar todas essas pessoas no meu caminho!

OBRIGADA! 


\section{SUMÁRIO}

\section{* CAPÍTULO 1}

\section{PLASTICIDADE NO SISTEMA NERVOSO CENTRAL E BENEFÍ́CIOS DO EXERCÍCIO FÍSICO................................................................ 16}

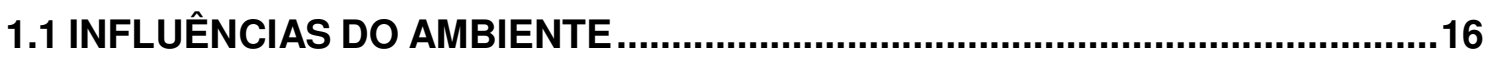

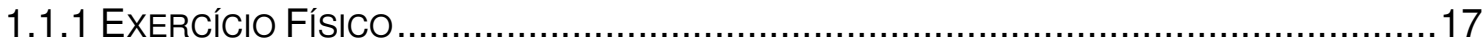

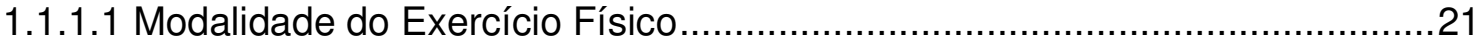

1.1.1.2 Intensidade do Exercício Físico ........................................................22

1.1.1.3 Duração do Protocolo de Exercício Físico.................................................24

* CAPÍTULO 2

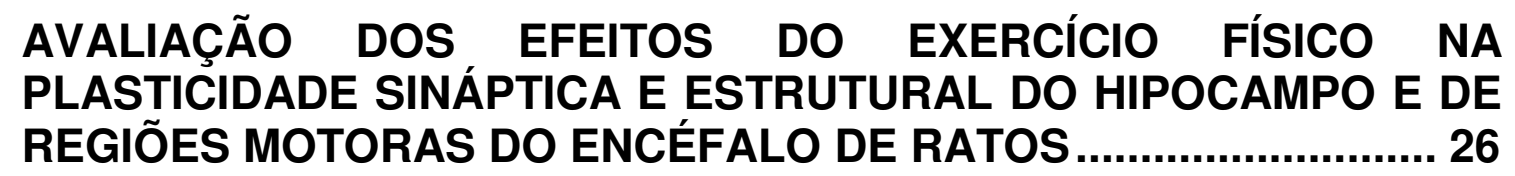

2.1 MARCADORES DE PLASTICIDADE ESTUDADOS …...................................26

2.1.1 FATOR NEUROTRÓFICO DERIVADO DO ENCÉFALO (BDNF) ................................27

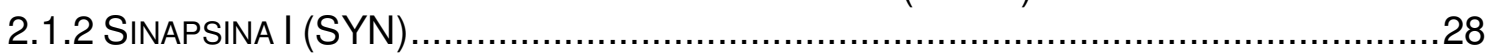

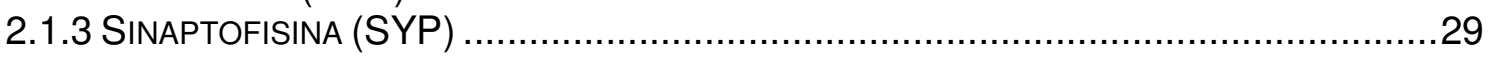

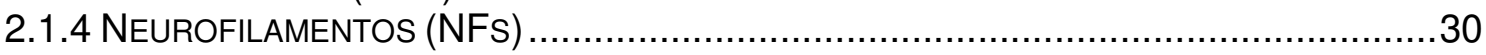

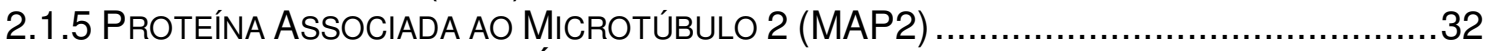

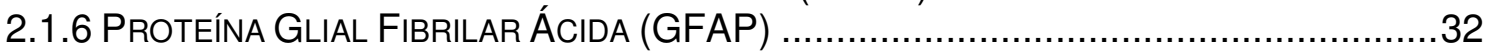

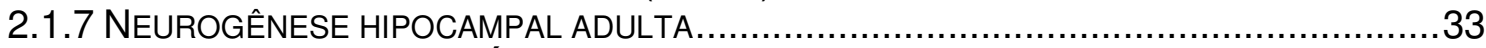

2.2 ESTRUTURAS ENCEFÁLICAS ESTUDADAS ...........................................34

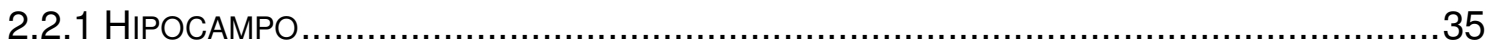

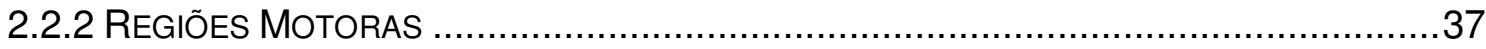

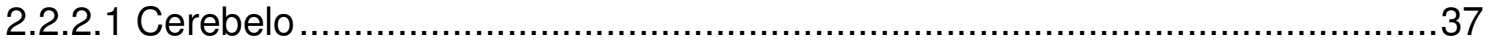

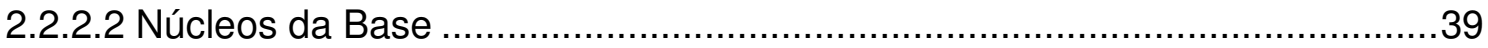

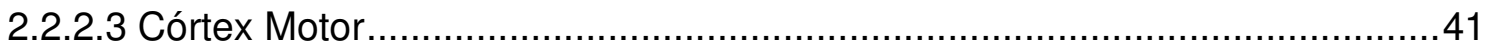

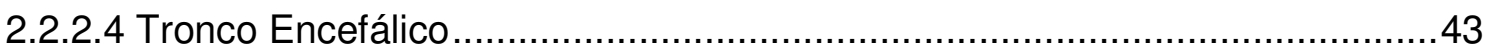

2.3 JUSTIFICATIVA E OBJETIVOS ....................................................................45

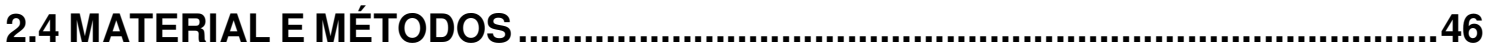

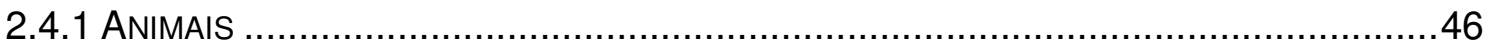

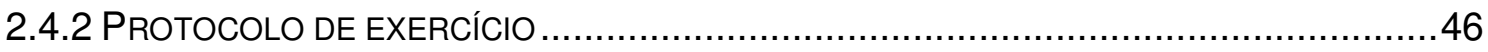

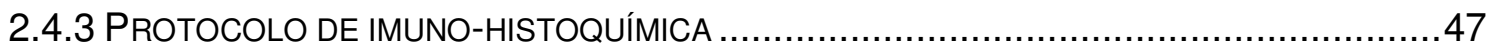

2.4.4 PROTOCOLO DE WESTERN BLOTTING ........................................................ 49

2.4.5 PROTOCOLO DE EXTRAÇÃO DO RNA TOTAL, SíNTESE DE CDNA E PCR EM TEMPO

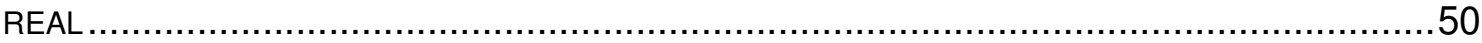


2.4.6 PROTOCOLO PARA AVALIAÇÃO DE NEUROGÊNESE HIPOCAMPAL ADULTA ....................52

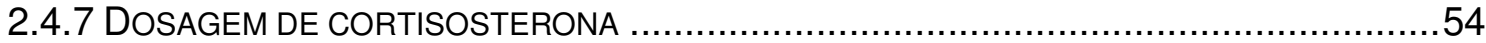

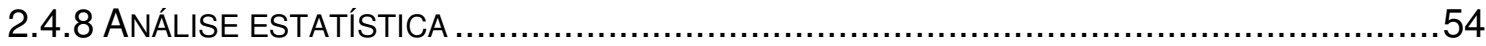

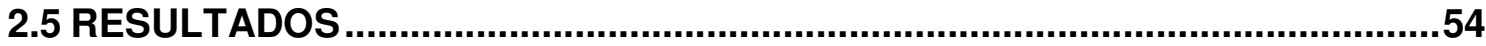

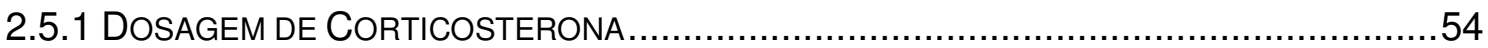

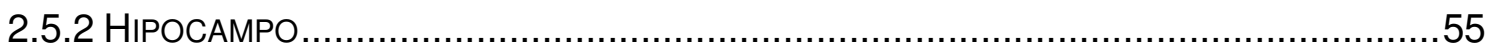

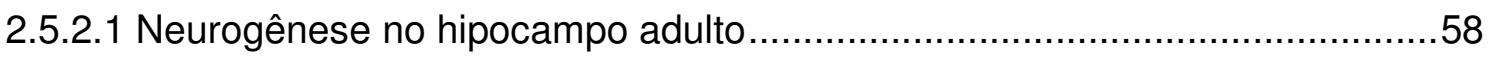

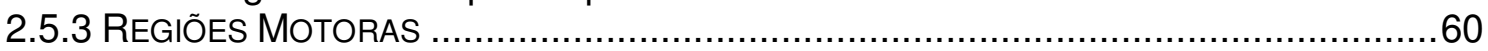

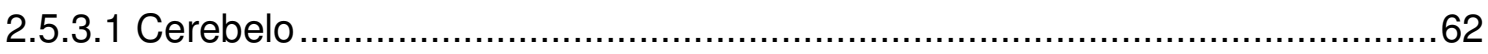

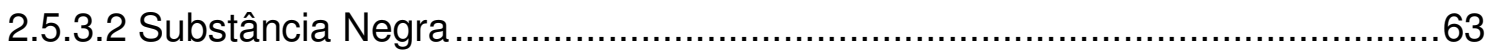

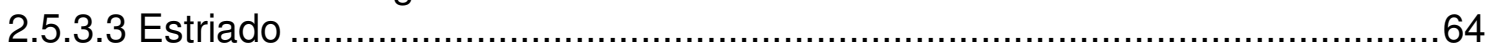

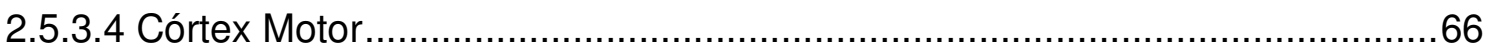

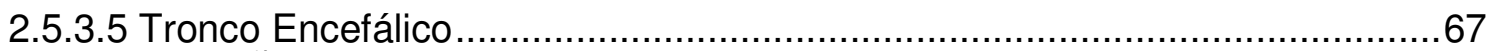

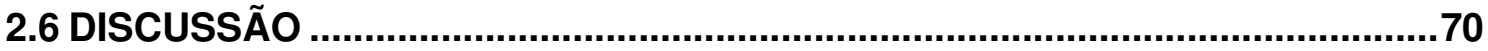

2.6.1 Protocolo de EXERcício e CoRTICOSTERONA PlasmÁtICA ............................... 70

2.6.2 EFEITOS DO EXERCÍCIO NO HIPOCAMPO DE RATOS .......................................... 72

2.6.3 EFEITOS DO EXERCÍCIO EM REGIÕES MOTORAS DO ENCÉFALO DE RATOS................76

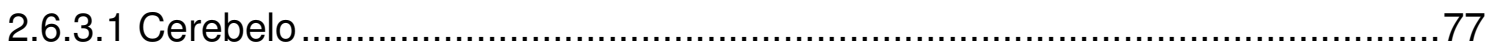

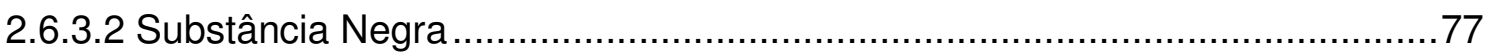

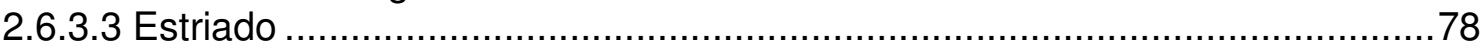

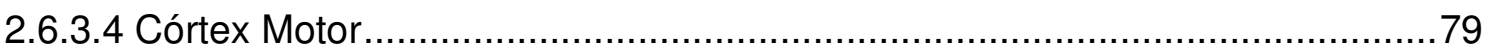

2.6.3.5 Formação reticular do tronco encefálico............................................... 79

\section{* CAPÍtULO 3}

\section{AVALIAÇÃO DOS EFEITOS DO EXERCÍCIO FÍSICO SOBRE A UNIDADE/COMUNICAÇÃO NEUROVASCULAR NO ENCÉFALO DE RATOS........................................................................................... 81}

3.1 ATIVAÇÃO NEURONAL E O FLUXO SANGUÍNEO CEREBRAL (FSC) ............81

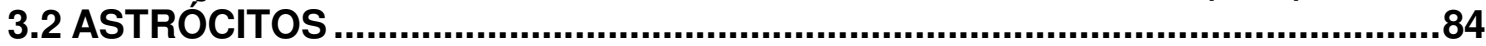

3.3 SISTEMA ENDOTELINÉRGICO NOS ASTRÓCITOS .....................................85

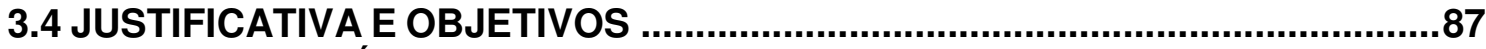

3.5 MATERIAL E MÉTODOS .....................................................................................88

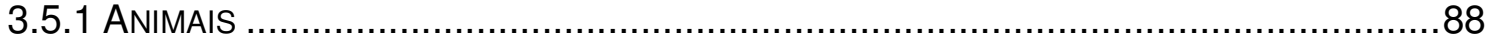

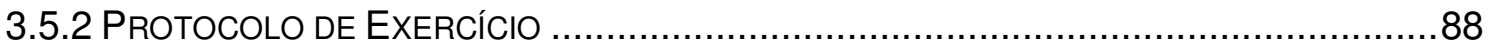

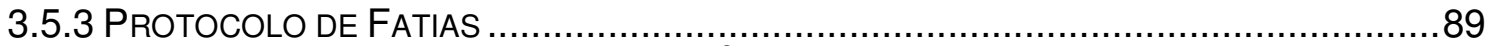

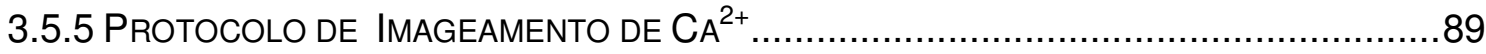

3.5.6 INJEÇÕES DE FLUORESCEIN ISOTHIOCYANATE-DEXTRAN (FITC-DEXTRAN)..............91

3.5.7 IMUNOFLUORESCÊNCIA PARA ESTUdO DE DENSIDADE VASCULAR E DE PROCESSOS

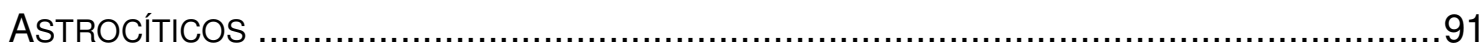

3.5.8 IMUNOFLUORESCÊNCIA PARA ESTUDO DE COLOCALIZAÇÃO DO RECEPTOR ET $\mathrm{B}_{\mathrm{B}} \mathrm{R}$ COM

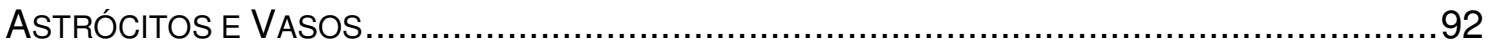

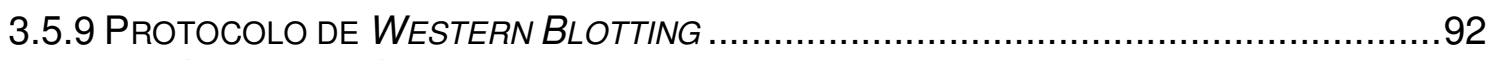

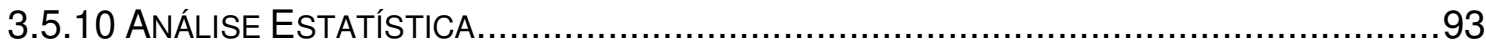

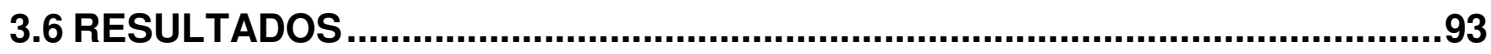


3.6.1 IMAGEAMENTO DE CA ${ }^{2+}$

* CAPÍTULO 4

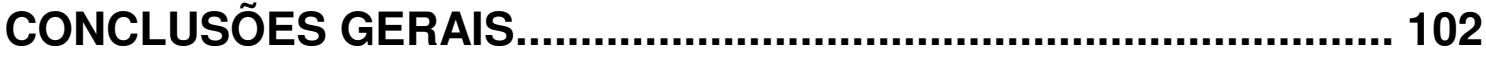

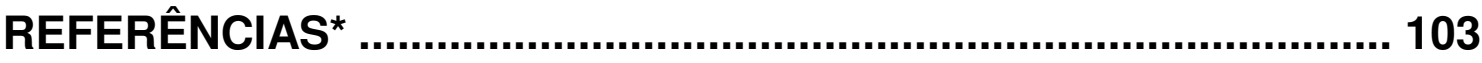

ANEXO A - ARTIGO PUBLICADO ……............................................ 131

ANEXO B - ARTIGO SUBMETIDO ……......................................... 144

ANEXO C - ARTIGO EM FASE DE PREPARAÇÃO...........................146 


\section{RESUMO}

Ferreira AFB. Neuroplasticidade Induzida pelo Exercício: Efeitos sobre o Hipocampo e Regiões Motoras do Encéfalo de Ratos [tese (Doutorado em Fisiologia Humana)]. São Paulo (Brasil): Instituto de Ciências Biomédicas da Universidade de São Paulo; 2011.

O exercício físico traz inúmeros benefícios para o sistema nervoso central, dentre eles a melhora da memória e cognição, o aumento da plasticidade e aprendizado, além de um efeito protetor em relação ao declínio mental decorrente do envelhecimento e de lesões do sistema nervoso. Este estudo teve como objetivo observar os efeitos plásticos do exercício moderado de curta duração no hipocampo e em regiões motoras do encéfalo de ratos, frequentemente afetadas por lesões ou doenças neurodegenerativas. As metodologias empregadas nestas análises foram a imuno-histoquímica, o Western blotting e o PCR em tempo real. Avaliamos também os níveis de neurogênese pela injeção de BrdU associada à marcação de doublecortin (DCX) e os efeitos do exercício sobre os eventos intracelulares de $\mathrm{Ca}^{2+}$ de astrócitos corticais por imageamento de $\mathrm{Ca}^{2+}$. Os resultados encontrados mostram que o protocolo de exercício utilizado promoveu alterações plásticas específicas em todas as regiões estudadas, variando na dependência do marcador utilizado e do decurso temporal do exercício. No hipocampo observamos aumento dos níveis protéicos de sinapsina I (SYN), neurofilamento 68kDa (NF68), proteína associada ao microtúbulo 2 (MAP2) e proteína glial fibrilar ácida (GFAP), além do aumento dos níveis de neurogênese hipocampal. Para as regiões motoras, observamos que no cerebelo houve aumento dos níveis de SYN e NF68, na substância negra de NF68 e NF160, no estriado de SYN, sinaptofisina (SYP) e NF68, no córtex motor de NF68 (apesar da redução que o precedeu) e na formação reticular dos NFs de todos os pesos moleculares. Além disso, observamos também efeitos do exercício sobre a expressão de RNAm para alguns destes marcadores, apesar dos níveis de BDNF (fator neurotrófico derivado do encéfalo), importante mediador de plasticidade induzida pelo exercício, permanecerem inalterados. Os experimentos de imageamento de $\mathrm{Ca}^{2+}$ revelaram que o exercício provocou um aumento da resposta dos astrócitos corticais ao agonista do receptor de endotelina tipo $B\left(E T_{B} R\right)$, possivelmente devido à sensibilização do receptor, além de provocar um atraso da resposta dos astrócitos ao peptídeo endotelina 1. A regulação do 
sistema endotelinérgico astrocítico favorecendo o $\mathrm{ET}_{\mathrm{B}} \mathrm{R}$ sugere um papel protetor do exercício devido às funções deste receptor na comunicação entre astrócitos e na regulação da vasoconstricção promovendo vasodilatação. Foi observado também um aumento da densidade de processos astrocíticos na camada cortical II na ausência de alteração da densidade vascular. Diante deste conjunto de achados em diferentes regiões do encéfalo, acreditamos que o exercício moderado de curta duração é suficiente para promover plasticidade difusa no sistema nervoso, que pode ser parte do substrato do efeito benéfico do exercício no sistema nervoso.

Palavras-chave: Exercício. Hipocampo. Cerebelo. Substância Negra. Estriado. Córtex motor. Tronco encefálico. Plasticidade sináptica. Plasticidade estrutural. Neurogênese. Astrócitos. Sinalização de cálcio intracelular. Endotelinas. 


\begin{abstract}
Ferreira AFB. Exercise-induced Neuroplasticity: Effects on the Hippocampus and Motor Regions of the rat brain [Ph. D. thesis (Human Physiology)]. São Paulo (Brasil): Instituto de Ciências Biomédicas da Universidade de São Paulo; 2011.
\end{abstract}

Evidence shows that physical exercise is neuroprotective and enhances brain function by improving cognition, learning and memory. Exercise has also been associated with structural changes such as angiogenesis, synaptogenesis and neurogenesis. However, it remains unclear which effects can be achieved with each of the various protocols that have been proposed. The aim of this study was to observe the effects of a moderate, short-term exercise protocol on the hippocampus and brain regions related to motor function, commonly affected by neurodegenerative diseases. The methods used for these analyses were immunohistochemistry, Western blotting and real-time PCR. We also evaluated the levels of hippocampal neurogenesis with injections of BrdU followed by staining for doublecortin (DCX), the effects of exercise on intracellular $\mathrm{Ca}^{2+}$ events of cortical astrocytes by $\mathrm{Ca}^{2+}$ imaging and the density of astrocytic processos and blood vessels by immunofluorescence. Our results show that the present exercise protocol induced specific plastic changes in all regions studied, which varied depending on the marker and time course of exercise. In the hippocampus, we observed increased levels of synapsin I (SYN), neurofilament 68kDa (NF68), microtubule-associated protein 2 (MAP2) and glial fibrilary acidic protein (GFAP), accompanied by increased neurogenesis. As for the motor regions, we observed increases of SYN and NF68 in the cerebellum, of NF68 and NF160 in the substantia nigra, of SYN, synaptophysin (SYP) and NF68 in the striatum, of NF68 (preceded by a decrease) in the motor cortex and of all neurofilaments in the reticular formation. We also observed exercise-induced changes of mRNA expression for some of these markers, even though the levels of BDNF (brain-derived neurotrophic factor), an important mediator of exercise-induced plasticity, remained unchanged. The $\mathrm{Ca}^{2+}$ imaging experiments revealed that exercise induced increased responsiveness to the endothelin receptor type $B\left(E T_{B} R\right)$, likely via sensibilization of the receptor, and induced a delay in the response to the peptide endothelin 1. The modulation of the astrocytic endothelin system in favor of $E T_{B} R$ suggests a protective effect of exercise. We also observed increased density of astrocytic processes in the cortical layer II and the absence of changes of vascular 
density. These results for the various brain regions suggest that short-term moderate physical exercise is enough to modulate synaptic and structural elements of neurons as well as astrocytes, playing an important role in the diffuse exercise-dependent plasticity of the hippocampus and of brain regions related to motor control. That plasticity process may underlie the beneficial effects of exercise in the brain.

Key-words: Exercise. Hippocampus. Cerebellum. Substantia nigra. Striatum. Motor cortex. Brainstem. Synaptic plasticity. Structural plasticity. Neurogenesis. Astrocytes. Intracellular calcium signaling. Endothelins. 


\section{* CAPÍTULO 1}

\section{PLASTICIDADE NO SISTEMA NERVOSO CENTRAL E BENEFÍCIOS DO EXERCÍCIO FÍSICO}

\subsection{INFLUÊNCIAS DO AMBIENTE}

Aspectos da vida diária modulam a capacidade cognitiva e a evolução do cérebro (Gomez-Pinilla, 2008). Estudos das últimas duas décadas indicam que o encéfalo e outros tecidos excitáveis são maleáveis e mudam em resposta a interações com o ambiente (Azizi e Vendrame, 2007). Atividades fisiológicas e patológicas regulam a neurogênese no encéfalo adulto em todos os seus níveis, incluindo a proliferação de células tronco neurais, diferenciação, migração, sobrevivência, maturação e integração de novos neurônios na circuitaria local (Zhao et al., 2008). O fluxo sanguíneo cerebral (FSC) também é influenciado pelo nível de atividade neuronal em resposta a estímulos, uma vez que neurônios em atividade precisam receber um aporte adequado de oxigênio e glicose (Filosa et al., 2004; Nishijima e Soya, 2006; Roy e Sherrington, 1890).

A exposição a ambientes enriquecidos pode modular a plasticidade sináptica no hipocampo, aumentando tanto a potenciação de longo prazo (LTP), quanto a depressão de longo prazo (LTD). O estresse agudo, por sua vez, reduz a capacidade de indução de LTP, podendo esta redução ser revertida com ambiente enriquecido (Artola et al., 2006). Ambientes ditos enriquecidos oferecem diversos estímulos de variados graus de dificuldade. Estes tipicamente consistem de componentes como interação social (ex. gaiolas com 14 ratos), estímulos ao comportamento exploratório (ex. com brinquedos e túneis que podem ser rearranjados) e exercício (ex. roda de correr). Em modelos animais, geralmente estes estímulos são trocados periodicamente para manter o caráter de novidade dos estímulos (van Praag et al., 1999). O tipo de atividade, ou tarefa, e a forma como esta é realizada tem diferentes efeitos sobre o encéfalo (Holschneider et al., 2007). Uma tarefa pode ser definida por exigir uma grande quantidade de guia atencional ou não; ou pode ser definida por ser guiada interna ou externamente, o que sugere o recrutamento de diferentes circuitos motores (Lewis et al., 2007). Movimentos 
motores guiados internamente, ou seja, iniciados voluntariamente, apresentam um domínio do circuito núcleos da base-talâmico-cortical (BTC), enquanto que movimentos guiados por pistas externas apresentam um domínio do circuito cerebelar-talâmico-cortical (CbTC) (Lewis et al., 2007). Estes circuitos parecem estar em equilíbrio. Durante o aprendizado inicial, os movimentos são mais guiados internamente, havendo predomínio do circuito BTC, e quando os movimentos vão se tornando mais automáticos e guiados externamente, a influência deste circuito diminui, havendo então predomínio do circuito CbTC (Holschneider et al., 2007). A tarefa por exemplo de caminhar sobre uma escada horizontal tendo que controlar a passada para pisar apenas onde se encontra um degrau aumenta a atividade de neurônios do córtex motor (incluindo os de origem no trato piramidal) e do cerebelo (como as células de Purkinje e neurônios dos núcleos cerebelares) de gatos (Armstrong e Marple-Horvat, 1996).

Até mesmo hábitos alimentares são capazes de influenciar a função do sistema nervoso, prevenindo e protegendo contra doenças. A influência de sinais viscerais sobre a função mental pode ser estimulada por fatores alimentares, agindo sobre sistemas moleculares específicos e mecanismos que mantêm a função mental (Gomez-Pinilla, 2008). Há evidências de que, por exemplo, uma dieta rica em omega-3 dá suporte a processos cognitivos em humanos (McCann e Ames, 2005) e regula positivamente genes importantes para a função e plasticidade sináptica em roedores (Wu et al., 2007).

\subsubsection{EXERCícIo Físico}

Diversas evidências mostram que exercícios físicos, independente da modalidade, trazem inúmeros benefícios ao sistema nervoso de humanos (Dustman et al., 1990; Kramer et al., 1999; Lupinacci et al., 1993) e animais (Gomez-Pinilla et al., 2002; Marin et al., 2003; Molteni et al., 2002; Vaynman et al., 2004b; Ying et al., 2005). Estudos comprovam melhoras no aprendizado, na memória e na plasticidade do sistema nervoso como resposta ao exercício (Lambert et al., 2005; Molteni et al., 2002; Molteni et al., 2004b; Neeper et al., 1995; van Praag et al., 2005; Vaynman et al., 2004b), sendo este responsável também por aumentar a vascularização (angiogênese) cerebral (Isaacs et al., 1992; Swain et al., 2003) e atenuar o declínio mental decorrente do envelhecimento (Laurin et al., 2001). Técnicas de 
neuroimagem como ERP (event-related brain potentials) e ressonância nuclear magnética estrutural e funcional têm sido utilizadas para avaliar a relação do exercício com a cognição (Hillman et al., 2008). Testes de memória como o de habituação em campo aberto, reconhecimento de objetos e o teste de memória espacial (como o labirinto aquático de Morris) também são amplamente utilizados em animais para avaliar esta relação (Mello et al., 2008).

Foi observado um efeito protetor do exercício no sistema nervoso, aumentando a resistência a lesões (Ding et al., 2004; Cotman e Berchtold, 2002; Gentile et al., 1987) e facilitando a recuperação funcional pós-lesão (Edgerton et al., 2004; Grealy et al., 1999; Mattson, 2000). O exercício protege o sistema nervoso minimizando o dano por lesão por falta de glicose e oxigênio em fatias (Cechetti et al., 2007). In vivo, o exercício reduz o dano neuronal em gerbos submetidos a isquemia (Stummer et al., 1994) e apresenta redução do volume do infarto em ratos treinados submetidos a isquemia focal (Wang et al., 2001).

As adaptações que o exercício causa no sistema nervoso têm implicações na prevenção e tratamento de obesidade, câncer, depressão, declínio cognitivo associado ao envelhecimento e com distúrbios neurológicos como doença de Parkinson, doença de Alzheimer, acidente vascular isquêmico e lesões medulares ou encefálicas (Dishman et al., 2006; Sutoo e Akiyama, 2003).

Em um modelo experimental da doença de Parkinson, induzido pela injeção intrastriatal de 6-hidroxidopamina, foi observado que os animais submetidos a 2 semanas de exercício em esteira (30 min/dia) apresentavam redução significativa da assimetria rotacional (observada após injeção de apomorfina) e maior sobrevivência de neurônios dopaminérgicos na substância negra (e de suas fibras que se projetam ao estriado) em relação aos controles sedentários (Yoon et al., 2007). Já em humanos (Chen et al., 2005), um estudo prospectivo com pacientes apresentando estágios iniciais da doença de Parkinson mostrou que 24 sessões de exercício em esteira, além de normalizarem a excitabilidade córtico-motora, provocaram melhora na performance funcional, aumentando a velocidade da marcha, alargando a passada, aumentando a excursão dos movimentos do quadril e tornozelo e melhorando a distribuição de peso durante tarefas senta-levanta (Fisher et al., 2008).

Já em um modelo experimental da doença de Alzheimer induzida pela injeção intracerebroventricular (icv) de estreptozotocina (STZ), observou-se que o exercício 
em esteira realizado após a injeção preveniu parciamente a redução da memória de longo prazo induzida pela STZ e em algumas regiões do hipocampo de ratos preveniu parcialmente a redução do número de células positivas para c-Fos após injeção de STZ (Jee et al., 2008). O exercício após a STZ também se mostrou capaz de evitar déficits cognitivos espaciais, estresse oxidativo e a redução da proteína glial $\mathrm{S} 100 \beta$ no flúido cérebroespinal (CSF), além de aumentar GFAP (proteína glial fibrilar ácida) e glutationa na região CA1 (Rodrigues et al., 2010). Exercício em roda de correr também melhorou o desempenho cognitivo de modelos transgênicos de doença de Alzheimer (Nichol et al., 2007). A falta de exercício por sua vez parece estar associada a níveis mais altos de tau, tau fosforilada e à tendência a menores níveis de $A \beta_{42}$ em adultos cognitivamente normais (Liang et al., 2010).

Há também estudos clínicos, com doenças como a epilepsia, que mostram um efeito benéfico do exercício na frequência e na severidade das crises epilépticas (Denio et al., 1989; Eriksen et al., 1994), sugerindo que o exercício eleva o limiar das crises e pode desempenhar um papel protetor também nestes pacientes (Gotze et al., 1967; Livingston 1978). Em modelos animais é observada uma redução do número de crises em animais submetidos a treinamento físico (Arida et al., 2007). Estudos eletrofisiológicos mostraram uma redução da hiperresponsividade da região CA1 do hipocampo e aumento da magnitude da potenciação de longo prazo no hipocampo em ratos epilépticos treinados (Arida et al., 2004a). Foi observado um número maior de células marcadas para parvalbumina tanto em animais controles que corriam, quanto em animais epilépticos que corriam, quando comparados aos seus respectivos controles sedentários. Parvalbumina é um marcador sensível de células hipocampais, particularmente de uma população de interneurônios inibitórios (Freund e Buzsaki, 1996). Este aumento de células marcadas para parvalbumina, contudo, foi observado nos animais epilépticos apenas para os que realizaram protocolos agudos de corrida (tanto voluntária quanto forçada), enquanto que os controles que corriam apresentaram aumentos tanto para protocolos agudos (10 dias) quanto crônicos (45 dias) (Arida et al., 2007).

$\mathrm{Na}$ lesão medular, o exercício pode ser utilizado como facilitador da recuperação funcional. Foi observado que, após 4 semanas de exercício em esteira com suporte gravitacional, camundongos com hemissecção torácica baixa apresentaram melhoras significativas do uso do membro parético. Estes animais apresentaram menor atrofia muscular, aumento da regeneração axonal e 
brotamento colateral próximo à lesão com manutenção de marcadores sinápticos nos neurônios motores do corno ventral da medula. Acredita-se que estas melhoras se devem, pelo menos em parte, ao aumento da atividade neuronal acima da lesão (Goldshmit et al., 2008). Outros estudos demonstram também que o uso do membro comprometido (por acidente vascular ou doença de Parkinson) pode alterar a atividade do encéfalo pela reorganização de aferências, ativando áreas alternativas do encéfalo (Cohen et al., 2003; Liepert et al., 2004; Ramanathan et al., 2006).

Acreditava-se que doenças neurológicas, como Alzheimer e Parkinson, e lesões como acidente vascular, resultavam na perda permanente de neurônios sem qualquer possibilidade de regeneração celular (van Praag et al., 1999). Hoje já se sabe que algumas regiões do encéfalo (sabidamente a zona subventricular dos ventrículos laterais e a zona subgranular do giro denteado do hipocampo) são capazes de gerar neurônios novos por toda a vida adulta de mamíferos (Azizi e Vendrame, 2007; Zhao et al., 2008). Processos como a neurogênese encontram-se aumentados após exercício físico, assim como a complexidade dendrítica e a sinaptogênese no giro denteado (Eadie et al., 2005; Redila e Christie, 2006; Redila et al., 2006; van Praag et al., 1999; van Praag et al., 2002). O exercício físico pode afetar a neuroquímica hipocampal (Fordyce e Wehner, 1993), a atividade neuronal (Vissing et al., 1996), a expressão de fatores tróficos (Gomez-Pinilla et al., 1997; Neeper et al., 1996) e a proliferação e sobrevivência de células granulares (van Praag et al., 1999). Foi observado que o exercício voluntário por 2 semanas aumentou o número de células novas no hipocampo de ratas submetidas a ovariectomia, portanto privadas de estrógeno, o que sugere que o exercício também pode beneficiar a função cerebral de mulheres no climatério (Jin et al., 2008).

O exercício atenua respostas neurais ao estresse, possivelmente contribuindo para a redução de patologias clínicas como hipertensão, insuficiência cardíaca, estresse oxidativo e imunodepressão (Dishman et al., 2006). A associação do exercício físico ao menor risco de infarto agudo do miocárdio e acidente vascular encefálico (Haheim et al., 1993; Salonen et al., 1982) se deve em parte ao fato de que exercícios aeróbicos regulares atenuam o espessamento da camada íntima média, o enrijecimento das artérias e a disfunção endotelial, e por outro lado, parecem aumentar o número e a função de células progenitoras endoteliais (Witkowski e Hagberg, 2007). 
A falta do exercício, por sua vez, diminui a auto-estima, aumenta a ansiedade e agrava a depressão (American College of Sports Medicine, 2000). O sedentarismo está relacionado a transtorno de humor, imunossupressão, piora do perfil lipídico, glicêmico e da qualidade do sono (McArdle, 1998; Nieman, 1999; Wilmore, 2001). Este estilo de vida de inatividade física está associado a outros fatores de risco como tabagismo, etilismo, hábitos alimentares inadequados e estresse emocional (Nieman, 1999). O exercício melhora a performance acadêmica em crianças e a falta deste, particularmente em crianças de países desenvolvidos ou em desenvolvimento, é uma das principais causas de obesidade (Hillman et al., 2008). O surgimento precoce de outras doenças crônicas, como o diabetes tipo II, também está envolvido com este estilo de vida (Secretary of Health na Human Services and the Secretary of Education, 2007). No diabetes, a plasticidade pré-sináptica parece estar afetada no giro denteado de ratos, porém exercícios em esteira de intensidade moderada por 12 semanas previnem este efeito (Reisi et al., 2008).

Portanto, o exercício físico é uma valiosa abordagem terapêutica para prevenir doenças neurodegenerativas relacionadas com o envelhecimento (Mattson 2000), além de doenças que podem ocorrer durante toda a vida adulta, como doenças cardiovasculares, câncer de mama e cólon, obesidade, depressão e ansiedade (US Department of Health and Human Services, 2000). As recomendações para esta prática são de um mínimo de 30 minutos de atividade física moderada na maioria dos dias da semana (US Department of Health and Human Services, 2000; Centers for Disease Control and Prevention, 2003).

\subsubsection{Modalidade do Exercício Físico}

Uma das modalidades de exercício físico mais utilizadas para ratos é a corrida. Para alguns autores, a corrida forçada (em esteira, por exemplo) causa estresse físico e psicológico, diferente da corrida voluntária (Sherwin, 1998). Entretanto, o exercício em si é considerado uma forma de estresse, pois desafia a homeostase e se torna benéfico apenas quando feito adequadamente (Mastorakos et al., 2005; Rozman e Doull, 2003). Foi observado que após serem removidos de suas gaiolas com rodas de correr, quando testados em labirinto em cruz elevado, ratos apresentavam mais comportamentos indicativos de ansiedade (Grace et al., 2009). 
Exercício em esteira é um componente chave para muitos programas de reabilitação neurológica (Holschneider et al., 2007). Sendo o exercício em esteira uma tarefa de endurance guiada externamente, alguns autores hipotetizam que esta provoque alterações no circuito CbTC (Holschneider et al., 2007). Após treinamento no Rota-rod foi observada uma redução da ativação do estriado e córtex associada ao aumento da ativação do globo pálido (pars interna), o que é consistente com a diminuição da atividade das projeções inibitórias do estriado para o globo pálido (Holschneider et al., 2007). O treinamento no Rota-rod neste trabalho resultou no aumento da eficiência do processamento neural (córtex sensório-motor, estriado, vermis) e na maior influência do circuito CbTC (Holschneider et al., 2007). Treinamento diário em esteira também pode promover fortalecimento das sinapses pela ativação repetida da transmissão neuronal glutamatérgica (Chang et al., 2009). No estudo de Ding et al., (2002) foram comparados os efeitos de protocolos de exercício em Rota-rod e em esteira convencional e foi observado que ambos aumentaram a imunorreatividade para sinaptofisina em núcleos do lado direito do tálamo de ratos, porém apenas o Rota-rod promoveu a melhora da performance motora em uma série de testes motores (Ding et al., 2002).

O exercício em esteira também promove efeito neuroprotetor. Foi observado por Sim et al. (2005) que o exercício em esteira uma vez por dia por $30 \mathrm{~min} / \mathrm{dia}$ durante 10 dias promove melhoras da memória e reduz a morte neuronal provocada por isquemia no giro denteado de gerbos (Sim et al., 2005). Também foi mostrado que o exercício em esteira protege contra agentes excitotóxicos, prevenindo dano e perda neuronal (Carro et al., 2001).

\subsubsection{Intensidade do Exercício Físico}

É dito que o efeito protetor do exercício físico forma uma curva em "U" invertido em relação à intensidade do exercício: intensidade baixa é ineficaz, moderada protege e alta aumenta a vulnerabilidade (Cechetti et al., 2007). No entanto, muitos fatores têm que ser levados em conta ao avaliar o real efeito protetor do exercício, que pode variar em função do órgão em questão.

Ao avaliar a indução de c-fos (marcador de ativação neuronal) e a expressão de BDNF (brain-derived neurotrophic factor) no hipocampo de ratos como resposta ao exercício forçado agudo (7 dias de corrida) de diferentes intensidades, Soya et al. 
(2007) observaram que o RNAm para c-fos estava aumentado mesmo nos ratos submetidos a corrida de baixa intensidade (30 min/dia a $15 \mathrm{~m} / \mathrm{min})$. Contudo, os aumentos do RNAm e da proteína BDNF foram vistos apenas nos ratos que correram com intensidade baixa. A corrida com intensidade moderada $(25 \mathrm{~m} / \mathrm{min})$, que provocou elevação do lactato sanguíneo e dos níveis de corticosterona, induziu a redução do RNAm para BDNF (Soya et al., 2007b). Com este estudo, Soya et al. (2007) mostraram que pode-se obter mais benefícios para a função hipocampal com exercícios agudos de baixa intensidade (minimamente estressantes) quando comparados com exercícios mais extenuantes (Soya et al., 2007b). Esta hipótese é confirmada pelos achados de Lou et al. (2008) que demonstraram o aumento da expressão do RNAm de BDNF em ratos de 5 semanas de idade apenas no grupo que realizou exercícios em esteira de baixa intensidade (Lou et al., 2008).

A corrida aumenta a demanda metabólica e com maiores velocidades podese ultrapassar o limiar de lactato (ponto a partir do qual passa-se a acumular lactato no sangue) (von Duvillard, 2001; Wasserman et al., 1973). Exercícios que ultrapassam o limiar de lactato ativam o sistema hormonal e o sistema nervoso simpático, inclusive a resposta ao estresse (Galbo, 1992). Um marco do estresse no exercício é o limiar de lactato acima do qual o nível de ACTH (hormônio adenocorticotrófico) no plasma se eleva (Farrell et al., 1983), sendo a secreção de ACTH um indicativo de estresse (Pacak, 2000). Áreas específicas do hipotálamo parecem estar envolvidas na resposta ao estresse durante o exercício (Galbo, 1992).

Foi observado por Soya et al. (2007) que durante a corrida realizada acima do limiar de lactato (supra-LL: $25 \mathrm{~m} / \mathrm{min}$ ), o nível de ACTH aumentou significativamente. A corrida abaixo do limiar de lactato (sub-LL: $15 \mathrm{~m} / \mathrm{min}$ ), no entanto, apresentou níveis de ACTH similares aos níveis basais. A concentração plasmática de adrenalina aumentou apenas com intensidade de corrida supra-LL, mostrando sensibilidade relativa entre a ativação dos eixos hipotalâmico-pituitário-adrenal (HPA) e hipotalâmico-simpato-adrenal (HSA) e o estresse provocado pela corrida. $O$ aumento de glicose plasmática com a corrida supra-LL é consistente com o aumento de adrenalina pelo eixo HSA que resulta na mobilização de estoques hepáticos de glicogênio (maior demanda metabólica) (Soya et al., 2007a).

No hipotálamo destes animais, a marcação com c-fos mostrou um número significativamente maior de neurônios marcados em diversas regiões do hipotálamo 
no grupo de animais que realizou 30 minutos de corrida com intensidade supra- LL em comparação com o grupo controle e o grupo sub-LL. A corrida com intensidade sub-LL, por sua vez, não provocou ativação de $c$-fos em região alguma do hipotálamo (Soya et al., 2007a). Neste modelo de corrida com mínimo de estresse pôde-se observar também uma ativação rápida do FSC (Nishijima e Soya, 2006).

Intensidades moderadas de exercício também têm mostrado um efeito protetor quando analisado em fatias de hipocampos de rato da linhagem Wistar. Foi observada uma redução da liberação de LDH (lactato desidrogenase) causada pela privação de oxigênio e glicose em slices de hipocampo ratos que haviam sido submetidos a um protocolo de exercício de intensidade moderada (2 semanas, 20min/dia), enquanto que intensidades mais altas (2 semanas, 60min/dia) exacerbavam os danos cerebrais (Scopel et al., 2006).

A maioria dos modelos experimentais de exercício em animais utiliza programas diários, porém humanos raramente se exercitam com esta frequência. Humanos geralmente se exercitam esporadicamente, o que representa níveis modestos de atividade física (Folsom et al., 2000).

\subsubsection{Duração do Protocolo de Exercício Físico}

A determinação da duração do exercício nos estudos que avaliam seu potencial terapêutico é uma dúvida que persiste. Em seu trabalho de 2002, Molteni et al. demonstraram que, para alguns parâmetros, os exercícios agudos geravam maiores alterações que exercícios crônicos (Molteni et al., 2002).

Foi observado que corrida por períodos prolongados (24 dias) reduziu a proliferação de células progenitoras hipocampais em ratas hipertensas espontâneas (SHR) à metade dos valores encontrados para os controles que não correram. Em contrapartida, corrida por períodos mais curtos (9 dias) provocaram um aumento da proliferação de até 5x nos valores encontrados nos controles (Naylor et al., 2005). Corrida por períodos prolongados aumentou a resposta do eixo hipotalâmicopituitário-adrenal com hipertrofia da glândula adrenal (65\%) e aumentou os níveis plasmáticos de corticosterona, além de reduzir o peso do timo. A involução do timo ocorre quando os níveis de corticosterona são elevados cronicamente (Hori et al., 1993), portanto indicando que este protocolo prolongado induz resposta relacionada ao estresse. Estas respostas relacionadas ao estresse não foram observadas nos 
ratos que correram por períodos mais curtos (Naylor et al., 2005). Contudo, os efeitos negativos da corrida prolongada foram prevenidos pela restrição da distância percorrida por dia (Naylor et al., 2005). A depender da linhagem de rato que está sendo estudada, muitas vezes esta restrição se torna necessária. Fêmeas SHR, por exemplo, chegam a correr até $23 \mathrm{~km} /$ dia em rodas de corrida após 3 semanas, enquanto que machos SHR correm cerca de $9 \mathrm{~km} / \mathrm{dia}$. Machos Wistar e SpragueDawley, contudo, correm apenas cerca de $3 \mathrm{~km} /$ dia após 3 semanas (Jonsdottir e Hoffmann, 2000; Tong et al., 2001; Yamamoto et al., 2003). 


\section{AVALIAÇÃO DOS EFEITOS DO EXERCícIO FísICO NA PLASTICIDADE SINÁPTICA E ESTRUTURAL DO HIPOCAMPO E DE REGIÕES MOTORAS DO ENCÉFALO DE RATOS}

\subsection{MARCADORES DE PLASTICIDADE ESTUDADOS}

Mudanças na expressão gênica de sinalizadores celulares e proteínas de membrana têm sido amplamente observadas em resposta ao exercício. Os efeitos do exercício no sistema glutamatérgico são pesquisados desde 1955 (Vrba 1955). Já os estudos buscando avaliação de mediadores como o ácido gamaaminobutírico, o óxido nítrico e outros neuromediadores surgiram um pouco mais tarde (Chiodera et al., 1993; Ishide et al., 2000). Estudos mais recentes deram início a uma sequência de pesquisas avaliando o envolvimento de proteínas de vesículas sinápticas, como sinapsinas (Gomez-Pinilla et al., 2002; Griesbach et al., 2004a; Griesbach et al., 2004b; Molteni et al., 2004a; Vaynman et al., 2003, 2004a, b; Ying et al., 2005) e sinaptofisinas (Ding et al., 2002; Lambert et al., 2005; Marin et al., 2003) na plasticidade do sistema nervoso decorrente do exercício físico. A avaliação de elementos estruturais também tem mostrado efeitos plásticos de intervenções como o exercício e/ou ambientes enriquecidos, além de mostrar os efeitos da falta destes, como a redução do número de sinapses e de espinhos dendríticos em regiões envolvidas com a cognição (Kozorovitskiy et al., 2005). Pode haver também em decorrência do exercício mudanças na atividade e concentração de determinados subtipos de receptores (Sarbadhikari e Saha, 2006).

Exercício voluntário aumenta a capacidade do giro denteado do hipocampo de induzir LTP in vitro e in vivo (Christie et al., 2005; Farmer et al., 2004; van Praag et al., 1999). Vasuta et al. (2007) encontraram indução elevada de LTP nos potenciais provocados da via perforante em fatias de hipocampo de animais com acesso a exercício voluntário e o aumento do envolvimento da subunidade NR2A dos receptores de glutamato tipo NMDA (N-metil D-Aspartato) na LTD (Vasuta et al., 2007). O exercício também ativa diretamente os receptores glutamatérgicos tipo 
NMDA e estes aumentam a produção de BDNF e a neurogênese (Kitamura et al., 2003).

O exercício utiliza processos do metabolismo de energia e da plasticidade sináptica para promover a saúde do encéfalo, uma vez que o estudo de Ding et al. (2006) mostrou a regulação positiva de diversas proteínas no hipocampo de ratos pelo exercício, sendo a maioria delas envolvidas na função cognitiva (Ding et al., 2006b). Já o estudo de Kirchner et al. (2008) mostrou que o exercício em esteira alterou níveis protéicos de diversas proteínas relacionadas com a função mitocondrial (Kirchner et al., 2008).

É sugerido que o exercício aumenta fatores tróficos pelo incremento da atividade que o neurotransmissor serotonina exerce sobre a expressão gênica de alguns destes fatores (Cowen, 2007). Aumentos de fatores neurotróficos como BDNF, NGF (nerve growth factor) e FGF (fibroblast growth factor) no hipocampo e no córtex cerebral de ratos (Gomez-Pinilla et al., 1997; Neeper et al., 1995; Neeper et al., 1996; Russo-Neustadt et al., 1999; Russo-Neustadt et al., 2000) após o exercício têm sido observados. O IGF-I (insulin-like growth factor-I), por exemplo, é um fator de crescimento envolvido no processo de neurogênese e atua como neuroprotetor em animais submetidos a protocolos de exercício (Carro et al., 2001). O fator de crescimento endotelial vascular (VEGF) também parece estar envolvido com a neurogênese em ratos corredores (Fabel et al., 2003).

A seguir fazemos uma breve descrição dos marcadores de plasticidade aqui estudados.

\subsubsection{Fator Neurotrófico Derivado do EncÉfalo (BDNF)}

Neurotrofinas são fundamentais para muitas funções do sistema nervoso desempenhando papéis críticos na diferenciação celular, sobrevivência neuronal, migração, arborização dendrítica, sinaptogênese e plasticidade sináptica dependente de atividade. Uma das neutrofinas mais bem estudadas é o fator neurotrófico derivado do encéfalo (BDNF). Pequenas alterações dos níveis de BDNF ou um polimorfismo no gene do BDNF podem ocasionar comportamento alimentar anormal, alterações na memória episódica e aumento da susceptibilidade para desordens neuropsiquiátricas como ansiedade e depressão. Alterações estruturais, cognitivas e comportamentais sugerem que a expressão do BDNF é altamente 
regulada in vivo, com um controle temporal, espacial e estímulo-dependente (revisado por Greenberg et al., 2009).

A sinalização estimulada pelo BDNF através do seu receptor TrkB (tirosina kinase B) é necessária para a sobrevivência e morfogênese de neurônios do sistema nervoso. Além disso, é amplamente aceito que o BDNF tem papel crucial na plasticidade neuronal, regulando a plasticidade sináptica e a liberação de neurotransmissores (revisado por Numakawa et al., 2010). BDNF guia os axônios e, consequentemente, a formação e a plasticidade de sinapses. Também foi reportado que o BDNF induz mudanças na densidade de espinhos dendríticos e na morfologia dendrítica (revisado por Shen e Cowan, 2010). O BDNF também está envolvido nos mecanismos responsáveis pela indução e manutenção da LTP e o proBDNF facilita a LTD hipocampal (Numakawa et al., 2010).

Em humanos com lesão medular, exercícios por curtos períodos e intensidade moderada provocaram aumento da concentração plasmática de BDNF (Rojas Vega et al., 2008) e segundo Vaynman e Gómez-Pinilla (2005), o BDNF promove plasticidade sináptica e neurogênese no sistema nervoso adulto lesionado (Vaynman e Gomez-Pinilla, 2005).

\subsubsection{SINAPSINA I (SYN)}

As sinapsinas regulam a liberação de neurotransmissores (NT) pelos terminais nervosos e representam uma família de quatro fosfoproteínas associadas a vesículas: sinapsinas la e lb (chamadas de sinapsina I) e sinapsinas lla e Ilb (Nestler e Greengard, 1999). Acredita-se que a proteína sinapsina I, a mais abundante de todas as fosfoproteínas neuronais, é mediadora de interações de vesículas sinápticas com o citoesqueleto (Chin et al., 1995; Hart, 1999). Em seu estado basal, a sinapsina I desfosforilada está ligada à vesícula sináptica e ancora a vesícula ao citoesqueleto do terminal nervoso (Nestler e Greengard, 1999), formando uma reserva de vesículas de extrema importância para evitar um esgotamento de vesículas durante uma estimulação de alta frequência (Hilfiker et al., 2005; Vaynman et al., 2006). A condução do impulso nervoso estimula a fosforilação da sinapsina I, que se solta da vesícula, deixando esta disponível para exocitose e liberação do NT. A fosforilação da sinapsina I está envolvida em vários mecanismos dependentes de $\mathrm{Ca}^{2+}$ que regulam a liberação de NT, incluindo o fenômeno de 
potenciação pós-tetânica. Alguns NT estimulam ou inibem a fosforilação da sinapsina I ligando-se a receptores pré-sinápticos, alterando, portanto, as concentrações de $\mathrm{Ca}^{2+}$. Este processo explica em parte o mecanismo pelo qual NTs agem em receptores pré-sinápticos de terminais axônicos para modular a liberação de NT. As sinapsinas também desempenham um papel na sinaptogênese no desenvolvimento e no sistema nervoso adulto (Nestler e Greengard, 1999). Essas proteínas regulam o desenvolvimento neural, a formação e manutenção da estrutura pré-sináptica, o alongamento axonal e novas formações sinápticas (Vaynman et al., 2006).

Mudanças nas concentrações de sinapsinas foram observadas em estudos que avaliaram efeitos do exercício na plasticidade do sistema nervoso. Molteni et al. (2002) documentaram o aumento de sinapsina I no hipocampo de ratos em resposta a exercício agudo e crônico (Molteni et al., 2002). Nos anos seguintes, outros estudos, mostraram resultados semelhantes com variações no protocolo de exercício e com a interferência de outros fatores como a dieta dos ratos, lesão medular ou lesão encefálica traumática (Gomez-Pinilla et al., 2002; Griesbach et al., 2004a; Griesbach et al., 2004b; Molteni et al., 2004a; Molteni et al., 2004b; Vaynman et al., 2003, 2004a, b; Ying et al., 2005).

A função da sinapsina I e os efeitos do exercício sobre esta proteína estão intimamente relacionados ao importante fator trófico BDNF (Ding et al., 2006a; Elmariah et al., 2005; Vaynman et al., 2006). A fosforilação da sinapsina I ocorre após a ativação de componentes intracelulares (MAPK) mediada pelo BDNF, promovendo assim a mobilização de vesículas e aumentando a liberação de NT (Ding et al., 2006a; Elmariah et al., 2005; Numakawa et al., 2010).

O estudo de Vaynman et al. (2006) demonstrou que há um aumento de sinapsina I após 3 dias de exercício e em outro grupo experimental, com a função do BDNF bloqueada, este aumento não ocorreu. O BDNF, portanto, parece regular os níveis de RNAm, o estado de fosforilação e os níveis da proteína sinapsina I durante o exercício (Vaynman et al., 2006).

\subsubsection{SINAPTOFISINA (SYP)}

Outra proteína capaz de alterar a liberação de NT é a sinaptofisina, uma proteína associada a vesículas que é fosforilada em tirosina (Lau, 1999). Segundo 
Lodish et al. (2000), a sinaptofisina pode formar parte do poro de fusão entre a vesícula sináptica e a membrana plasmática (Lodish et al., 2000). Contudo, esta proteína parece estar mais relacionada com mecanismos de formação da vesícula sináptica e resgate de proteínas da vesícula sináptica por endocitose, importante para uma neurotransmissão rápida e eficiente (Vaynman et al., 2006). Há indícios de que a sinaptofisina pode estar relacionada também com a ancoragem da vesícula no terminal sináptico (Vaynman et al., 2006). O aumento de sinaptofisina indica a formação de vesículas sinápticas, que pode significar o aumento de vesículas nas sinapses existentes, ou a formação de novos terminais (Cotman, 1999; Vaynman et al., 2006).

As alterações da sinaptofisinas em resposta ao exercício também têm sido alvo de pesquisas. Ding et al. (2002) avaliaram, por imuno-histoquímica para sinaptofisina, as variações das sinapses no tálamo de ratos após treinamento com exercícios em esteira, sendo observada uma intensa reação naquela região encefálica (Ding et al., 2002). Já em 2003, Marin et al. observaram alteração não significante nos níveis de sinaptofisina em ratos com lesão isquêmica do encéfalo, apesar da melhora comportamental (Marin et al., 2003). Foram relatados aumentos da sinaptofisina em resposta ao exercício em regiões do neocórtex, hipocampo, estriado, cerebelo e córtex fronto-parietal (Lambert et al., 2005).

A sinaptofisina também tem relação importante com o BDNF. Em estudo realizado em 2005, Elmariah et al., demonstraram que ratos com deficiência de BDNF apresentavam níveis sinaptossomais reduzidos de proteínas de vesícula, como a sinaptofisina (Elmariah et al., 2005), e o bloqueio da função do BDNF nos ratos de Vaynman et al. (2006) também anulou os efeitos do exercício sobre os níveis de sinaptofisina (Vaynman et al., 2006).

\subsubsection{NEUROFILAMENTOS (NFS)}

O citoesqueleto neuronal é composto por três filamentos interconectados: os microfilamentos de actina, os microtúbulos e os filamentos intermediários (revisado por Julien, 1999). Os neurofilamentos, filamentos intermediários específicos de neurônios, são uns dos principais elementos estruturais dos neurônios e são muito mais numerosos nos axônios, especialmente nos axônios grandes. Diferentemente dos outros filamentos intermediários, NFs isolados são compostos morfologicamente 
por duas partes: o filamento central (10nm de diâmetro) e finos filamentos que se estendem lateralmente do filamento central chamados de projeções (4-5nm de diâmetro e 70-80nm de comprimento) (revisado por Gotow, 2000). Neurofilamentos são compostos por três tipos de proteínas: NF-L ou NF68, NF-M ou NF160 e NF-H ou NF200 (polipeptídeos com pesos moleculares baixo, médio e alto, respectivamente) (Alberts et al., 2002) que formam obrigatoriamente heteropolímeros, sendo necessária a co-polimerização do NF68 com pelo menos uma das subunidades mais pesadas em roedores. Em humanos, contudo, o NF68 sozinho pode formar homopolímeros. Na ausência do NF68, NF160 e NF200 não são capazes de formar filamentos de $10 \mathrm{~nm}$, resultando em hipotrofia axonal em camundongos (Julien, 1999). As subunidades dos NFs são bem fosforiladas e organizadas nos axônios, porém não no corpo celular ou nos dendritos, onde se encontram de forma irregular e/ou aleatória (Gotow, 2000).

Durante o crescimento axonal, subunidades de neurofilamentos são incorporadas em toda a extensão do axônio. Após o crescimento, quando o axônio já se conectou a sua célula-alvo, o diâmetro deste axônio pode ser aumentado. No entanto, o acúmulo anormal ou a má-formação destes neurofilamentos podem afetar o transporte axonal normal, como ocorre, por exemplo, na esclerose lateral amiotrófica (Julien, 1999; Alberts et al., 2002). Visto que estes elementos garantem o suporte estrutural do axônio, a interrupção desta estrutura ou das proteínas que ligam os neurofilamentos aos microtúbulos e aos filamentos de actina ao longo do axônio pode levar a desorganização axonal ou eventual degeneração (Alberts et al., 2002). Agregados anormais de NFs também são observados em doenças como a demência por corpos de Lewy e a doença de Parkinson, mas o aumento da proporção do NF68 restaura o crescimento radial e a árvore dendrítica. A redução da expressão de RNAm NF68, contudo, está associada à degeneração de neurônios vista na esclerose lateral amiotrófica e pode contribuir para o aumento do dano oxidativo a outros componentes celulares, agravando a progressão da doença (Julien, 1999).

Alterações nos neurofilamentos foram observadas na junção neuromuscular do músculo sóleo de ratos em resposta a diferentes intensidades de exercício. Altas intensidades de treinamento geraram maior brotamento no terminal nervoso do que intensidades mais baixas (Deschenes et al., 1993). Até pouco tempo atrás, alterações dos neurofilamentos no sistema nervoso central como resposta ao 
exercício não haviam sido pesquisadas. Porém, mais recentemente, foram observadas alterações na fosforilação de algumas proteínas em animais que haviam realizado exercícios em comparação com controles sedentários, e uma delas foi o neurofilamento NF68. Estas proteínas eram fosforiladas mais intensamente com o exercício quando comparadas com controles (Ding et al., 2006b).

\subsubsection{Proteína Associada ao Microtúbulo 2 (MAP2)}

Os microtúbulos e suas proteínas associadas (MAPs) têm papel fundamental no desenvolvimento de axônios e dendritos. No encéfalo adulto, MAP2a e MAP2b são as MAPs mais abundantes nos dendritos e estas participam do crescimento e arborização dendrítica, remodelamento dendrítico pós-lesão e estabelecimento e manutenção da sinaptogênese (Johnson e Jope, 1992; Matus, 1988; Sánchez et al., 2000; Tucker, 1990). Acredita-se que MAP2 regula o crescimento e polaridade neuronal por regular a dinâmica dos microtúbulos, determinando assim o formato do neurônio e controlando o equilíbrio entre a rigidez e a plasticidade em processos neuronais (Sánchez et al., 2000). O RNAm para MAP2 é transportado para os dendritos proximais para ser traduzido no local, tanto in vitro (Garner et al., 1988; Steward e Wallace, 1995) quanto in vivo em células granulares do giro denteado (Tucker et al., 1989).

Foi observado que o exercício físico é capaz de alterar a citoarquitetura neuronal aumentando a complexidade dendrítica e a densidade de espinhos dendríticos do giro denteado do hipocampo (Eadie et al., 2005; Redila e Christie, 2006), além de aumentar o comprimento dos dendritos nesta região (Stranahan et al., 2007).

\subsubsection{Proteína Glial Fibrilar Ácida (GFAP)}

A proteína glial fibrilar ácida é o principal filamento intermediário de astrócitos maduros (Messing e Brenner, 2003). Esta proteína foi descoberta por Larry Eng cerca de 40 anos atrás enquanto analisava placas de pacientes com esclerose múltipla (Eng et al., 1971). Pela abundancia desta proteína em astrócitos de vertebrados, acredita-se que ela seja de importância crítica para o sistema nervoso, porém esta importância ainda é pouco compreendida. Por outro lado, já foi observado que camundongos knock-out para GFAP são viáveis. Hipóteses levam a 
crer que GFAP determina a morfologia complexa dos astrócitos que inclue os múltiplos processos que fazem contato com a parede de vasos sanguíneos, recobrem sinapses neuronais, margeam nódulos de Ranvier e se interdigitam na superfície da artéria pial formando a glia limitante (revisado por Messing e Brenner, 2003). Estudos mais recentes têm mostrado a expressão de GFAP em células progenitoras neuronais, porém não se sabe o papel desta proteína nestas células (Johansson et al., 1999; Doetsch et al., 1999; Laywell et al., 2000; Malatesta et al., 2000; Noctor et al., 2001; Campbell e Gotz, 2002; Zhu e Dahlström, 2007).

Astrócitos parecem estar envolvidos em diversas patologias do sistema nervoso como trauma, isquemia, e neurodegeneração, onde se encontram alteradas sua morfologia e expressão de variados genes, como os que codificam GFAP, vimentina e nestina (revisado por Pekny e Pekna, 2004). Mutações nos genes que codificam GFAP levam, por exemplo, à doença de Alexander, porém os mecanismos pelos quais isto acontece são desconhecidos (revisado por Quilan et al., 2007).

Há evidências de que o exercício em esteira aumenta o número de astrócitos e os níveis de GFAP no córtex frontoparietal e no estriado de ratos exercitados (Li et al., 2005) e estimula a proliferação de astrócitos na zona subgranular (Uda et al., 2006).

\subsubsection{NEUROGÊNESE HIPOCAMPAL ADULTA}

A descoberta de neurogênese no encéfalo de mamíferos adultos derrubou o dogma de que o encéfalo adulto não tem a capacidade de gerar novos neurônios. Hoje em dia já é bem aceito que neurônios são continuamente adicionados em poucas regiões do encéfalo durante toda a vida adulta. A neurogênese adulta se origina de células progenitoras neurais que se encontram na zona subventricular (SVZ) do ventrículo lateral e na zona subgranular (SGZ) do giro denteado (DG) do hipocampo. Neurônios nascidos na SVZ migram até o bulbo olfatório e se tornam neurônios granulares e periglomerulares. Neurônios nascidos na SGZ se diferenciam e integram a rede local de neurônios como células granulares do DG (revisado por Deng et al., 2010). A integração ao circuito do DG depende de um processo de seleção atividade-dependente (van Praag et al., 2002; Kempermann et al., 2004) e então estas células se tronam indistinguíveis das células granulares nascidas durante o desenvolvimento embrionário (Kempermann et al., 2004). 
Sabe-se que a atividade física voluntária induz a neurogênese hipocampal adulta, aumentando a proliferação e sobrevivência de células (Ehninger e Kempermann, 2003; van Praag et al., 1999a, b; van Praag et al., 2005). Este aumento da neurogênese, contudo, é dependente da fase circadiana e do volume diário de exercício. Foi observado que camundongos tiveram níveis de neurogênese aumentados apenas quando faziam exercício em roda de correr por 3 horas e no meio do pedíodo ativo (ciclo escuro) (Holmes et al., 2004). É importante ressaltar que o efeito benéfico do exercício sobre a neurogênese hipocampal adulta é observado tanto em animais jovens, quanto em animais idosos (van Praag et al., 2005). Há, no entanto, a hipótese de que não é simplesmente o exercício que promove benefícios para o encéfalo, mas sim o exercício com desafios cognitivos (Fabel e Kempermann, 2008).

\subsection{ESTRUTURAS ENCEFÁLICAS ESTUDADAS}

Diversas regiões do sistema nervoso são alvo de pesquisa dos efeitos do exercício. As regiões mais estudadas são a medula espinal (Ishide et al., 2000; Ishide et al., 2003; Ishide et al., 2005; Kajekar et al., 2002; Nauli et al., 2001a; Nauli et al., 2001b; Reidman et al., 2000; Williams et al., 1995), a substância negra do mesencéfalo (Mabandla et al., 2004), o estriado (Dishman, 1997; Li et al., 2005; Liste et al., 1997; Mabandla et al., 2004; Meeusen et al., 1997; Poulton e Muir, 2005), o giro denteado (Farmer et al., 2004; Uysal et al., 2005) e o hipocampo de forma geral (Berchtold et al., 2005; Berchtold et al., 2002; Holmes et al., 2004; Molteni et al., 2002; Radak et al., 2001), o tálamo (Ding et al., 2002), o hipotálamo (Andersson et al., 2005; Kramer et al., 2000; Overton et al., 1994) e o córtex (Chu e Jones, 2000; Gentile et al., 1987; Leggio et al., 2005).

As regiões a serem analisadas foram escolhidas por serem frequentemente afetadas por doenças neurodegenerativas ou por lesões, por estarem envolvidas direta ou indiretamente com o planejamento e/ou execução do movimento, ou por sofrerem influência direta dos efeitos do exercício físico. Estas regiões são o hipocampo e regiões motoras como o cerebelo, os núcleos da base (especificamente a substância negra e o estriado), o córtex motor, e formação reticular do tronco encefálico. Segue uma breve descrição funcional e neuroanatômica destas regiões. 


\subsubsection{HIPOCAMPO}

Grande parte da informação disponível sobre a organização celular e conectividade intrínseca do hipocampo tem origem nos estudos clássicos de Ramon y Cajal e Lorente de Nó utilizando a técnica de Golgi. O hipocampo tem um grande número de regiões com citoarquiteturas distintas. A formação hipocampal é composta pelo giro denteado, pelo hipocampo propriamente dito que é subdividido em três campos do Corno de Ammon (CA1, CA2 e CA3), e pelo subiculum. Todas estas regiões da formação hipocampal apresentam três camadas, o que caracteriza - alocórtex. Elas também apresentam uma conectividade considerada preferencialmente unidirecional. As células granulares do giro denteado projetam suas fibras musgosas para o campo CA3 que por sua vez projeta axônios colaterais para a camada profunda ou polimórfica do giro denteado, sem inervar, contudo, as células granulares. Conexões unidirecionais também ocorrem entre CA3 e CA1 e entre CA1 e o subiculum. As principais projeções recebidas pelo hipocampo são provenientes do córtex entorrinal pela via perfurante e tem como destino o giro denteado, CA1 e o subiculum. O córtex entorrinal junto com o córtex perirrinal, o córtex pós-rinal e as áreas do presubiculum e parasubiculum formam a região chamada de parahipocampal (Paxinos, 2004). Contudo, as áreas consideradas como formação hipocampal podem variar entre autores. Muitos autores consideram a formação hipocampal como sendo composta pelo giro denteado, o hipocampo, o subiculum, presubiculum, parasubiculum e córtex entorrinal (Andersen et al., 2007).

O giro denteado é composto por três camadas de células: a camada molecular (relativamente desprovida de células e ocupada basicamente pelos dendritos das células granulares, em cesto e polimórficas), a camada de células granulares (principal camada de células que apresenta empacotamento denso de células granulares e uma população de células em cesto na sua camada mais profunda) e a camada de células polimórficas (também chamada de hilo e onde se encontram as células musgosas). A camada polimórfica é chamada por alguns autores de CA4, como se fosse a porção terminal da camada de células piramidais do hipocampo por sua justaposição a esta camada e pela dificuldade de distinção entre os grupos celulares de ambas (Paxinos, 2004).

O hipocampo propriamente dito é dividido em duas regiões. A região proximal de células grandes compreende CA2 e CA3, enquanto que a região distal de células 
menores compreende CA1. A distinção entre CA3 e CA1 se dá pelo fato de que apenas CA3 recebe projeções das fibras musgosas do giro denteado. CA2, por sua vez, se distingue dos dois campos anteriores, pois ainda apresenta células grandes, como CA3, porém não recebe projeções das fibras musgosas, como CA1. A principal camada de células do hipocampo é a camada de células piramidais. As demais camadas que compõem a organização laminar do hipocampo são as camadas stratum oriens (relativamente desprovida de células), stratum lucidum (onde se encontram os axônios das fibras musgosas), stratum radiatum (onde se localizam as conexões associativas CA3-CA3 e as conexões do colateral de Schaffer entre CA3 e CA1) e stratum lacunosum-moleculare (por onde passa e termina a via perfurante). Já o subiculum margeia CA1 e o presubiculum. Este se distingue de CA1 por se notar um alargamento da camada de células piramidais, a ausência do stratum oriens e do stratum radiatum que é substituído pela larga camada molecular do subiculum (Paxinos, 2004).

De forma resumida, o hipocampo recebe aferências principalmente do córtex entorrinal através da via perfurante, cujas fibras fazem sinapses com neurônios do giro denteado. Os neurônios do giro denteado projetam seus axônios, as fibras musgosas, para fazerem sinapses com os neurônios da área $\mathrm{CA} 3$, que por sua vez se ramificam para sair do hipocampo pelo fórnix ou para estabelecerem sinapses com células de CA1 (Bear et al., 2002). As fibras que saem do hipocampo pelo fórnix se bifurcam em torno da comissura anterior para formar o componente precomissural (que seguirá para estruturas do prosencéfalo basal) e o póscomissural (que seguirá para o hipotálamo posterior no diencéfalo). Por fim, estas conexões originadas em CA1 irão retornar informação para o córtex entorrinal (Paxinos, 2004) (Fig.2-1).

O hipocampo desempenha importante papel em algumas formas de aprendizado e memória (Zhao et al., 2008). Outro aspecto que confere extrema importância a esta região seria a população de células tronco neurais nela encontrada. Além da zona subventricular dos ventrículos laterais, a zona subgranular do giro denteado do hipocampo é a única outra área onde foram identificadas estas células progenitoras no encéfalo de mamíferos adultos (Zhao et al., 2008). 


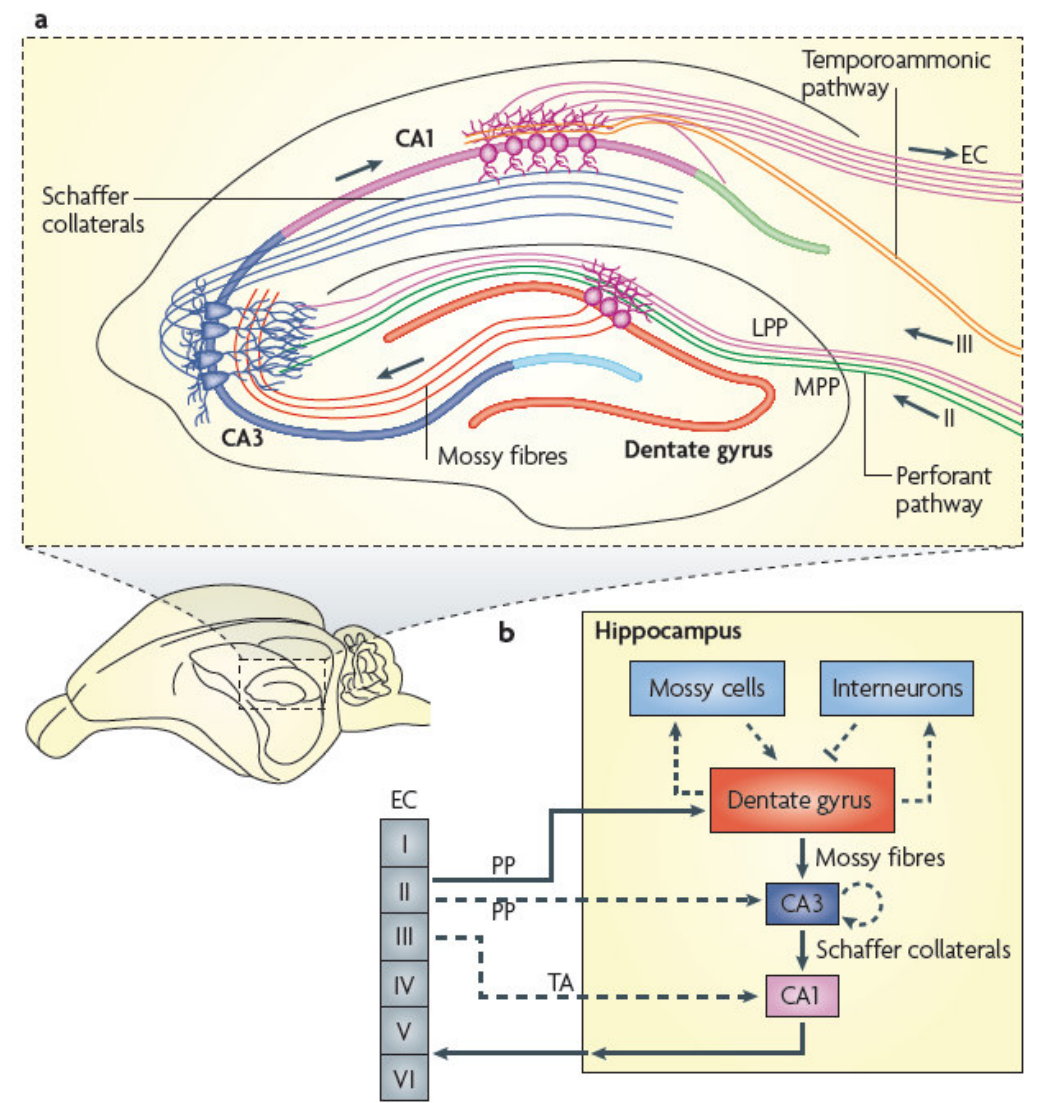

Figura 2-1. Ilustração dos principais circuitos da formação hipocampal de roedores. EC: córtex entorrinal; PP: via perfurante; LPP: via perfurante lateral; MPP: via perfurante medial. FONTE: Deng et al., 2010.

\subsubsection{REGIÕES MOTORAS}

\subsubsection{Cerebelo}

O cerebelo foi escolhido para esta análise por suas funções motoras, estando envolvido na manutenção do equilíbrio, tônus muscular e postura, além da coordenação dos movimentos (Machado, 1993). Sem a sua integridade, os movimentos ficam descoordenados e imprecisos (Bear et al., 2002).

O cerebelo é constituído pelo córtex cerebelar e pelo centro medular onde se encontram os núcleos centrais (Kiernan, 2003). Este se liga ao tronco encefálico por três pares de pedúnculos cerebelares (Bear et al., 2002; Kiernan, 2003). O cerebelo é dividido em 10 lóbulos rostro-caudalmente e fissuras rasas na superfície dos lóbulos 4 e 5 indicam as bordas entre o vermis e os hemisférios cerebelares. Funcionalmente, a continuidade médio-lateral do córtex cerebelar depende da 
presença de fibras paralelas da camada molecular (Paxinos, 2004). O vermis e os hemisférios representam importantes divisões funcionais. Enquanto o vermis envia eferências para as estruturas do tronco encefálico (contribuindo para as vias espinhais ventromediais que controlam a musculatura axial), os hemisférios se relacionam com outras estruturas, particularmente com 0 córtex cerebral (contribuindo para as vias laterais) (Bear et al., 2002).

Os núcleos cerebelares são divididos em dois grupos de núcleos interconectados. O grupo caudal consiste do núcleo cerebelar medial ou núcleo fastigial e do núcleo interposto posterior. O grupo rostral consiste do núcleo interposto anterior e do núcleo cerebelar lateral ou núcleo denteado. Fibras mielinizadas ocupam os espaços entre os dois grupos de núcleos. Nos núcleos cerebelares há uma população de neurônios inibitórios GABAérgicos que se projetam preferencialmente para a oliva inferior, e uma população de neurônios excitatórios, cujos colaterais dos seus axônios podem descer até a medula ou ascender até o tálamo. Células GABAérgicas dos núcleos cerebelares também emitem projeções para o córtex cerebelar, mas de forma geral são as células glutamatérgicas que fazem tais projeções pelas fibras musgosas. Além destas duas populações de células, foram encontrados nos núcleos cerebelares pequenos interneurônios glicinérgicos (Paxinos, 2004).

O córtex cerebelar tem como camada mais interna a camada granular, ficando abaixo da camada de células de Purkinje a da camada molecular. $\mathrm{Na}$ camada granular encontram-se os corpos celulares das células granulares cujos axônios sobem até a camada molecular para formar as fibras paralelas. A camada molecular é basicamente uma área de sinapses e nela se encontram além das fibras paralelas, os dendritos das células de Purkinje (formando sinapses com as fibras trepadeiras), os dendritos das células de Golgi e as células em cesto, todos fazendo sinapses com as fibras paralelas. As células granulares recebem sinapses de fibras musgosas (uma das portas de entrada para o cerebelo) e das células de Golgi, cujos corpos celulares também se encontram na camada granular e recebem sinapses de colaterais dos axônios de células de Purkinje. Portanto, é através das fibras paralelas das células granulares que as fibras musgosas exercem suas influências sobre as células de Purkinje (principal eferência do córtex cerebelar para os núcleos cerebelares centrais) (Kiernan, 2003) (Fig.2-2). Esta região do cerebelo contém a 
maioria das células do encéfalo, todas fazendo inúmeras sinapses com o intuito de regular o movimento (Bear et al., 2002).

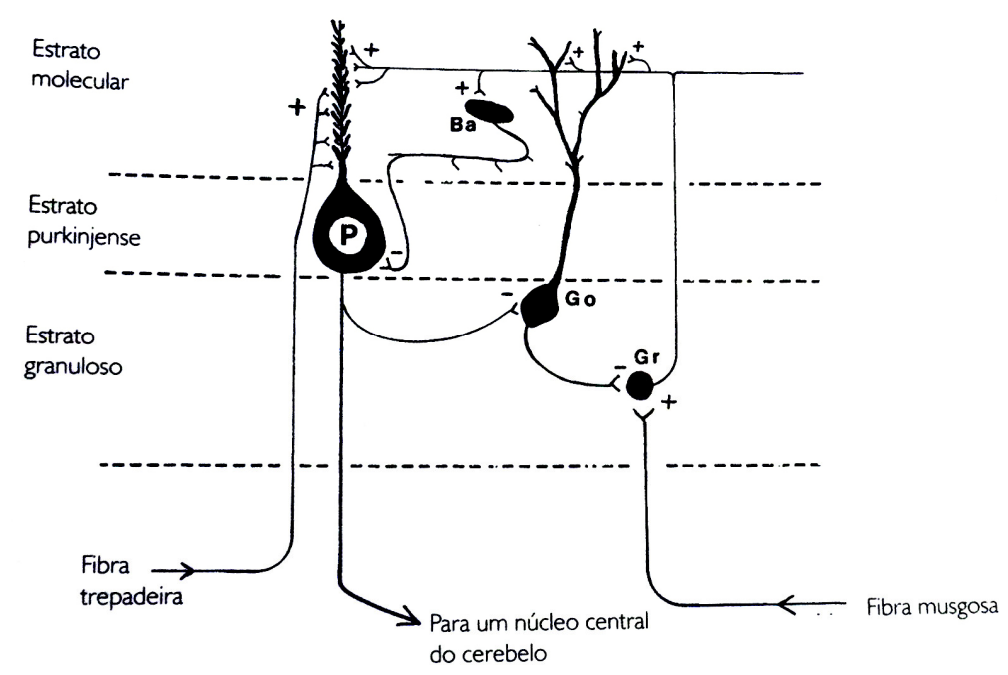

Figura 2-2. Neurônios no córtex cerebelar mostrandosinapses excitatórias e inibitórias. P: células de Purkinje; Go: células de Golgi; Gr: células granulares; Ba: células em cesto. FONTE: Kiernan, 2003.

\subsubsection{Núcleos da Base}

Os núcleos da base conectam o córtex cerebral a sistemas neurais que afetam o comportamento. A maioria das áreas neocorticais projeta, através de neurônios glutamatérgicos da camada 5, para os núcleos da base e estes mandam projeções de neurônios GABAérgicos para sistemas geradores de comportamento. Os núcleos talâmicos são alguns destes sistemas, projetando para áreas do córtex frontal envolvidas no planejamento e execução do movimento, assim como para o núcleo pedúnculopontino, envolvido na orientação de movimentos. A principal aferência dos núcleos da base é o estriado, formado pelo caudado-putamen e accumbens; e as principais eferências dos núcleos da base são o globo pálido medial e a substância negra pars reticulata (Paxinos, 2004).

Cerca de $90 \%$ do estriado é composto por neurônios GABAérgicos espinhosos de tamanho médio e que se encontram distribuídos de forma homogênea, configurando ao estriado uma citoarquitetura sem variação organizacional. Os demais neurônios encontrados no estriado são interneurônios que não se projetam para fora do estriado. Os neurônios GABAérgicos espinhosos 
são divididos em dois tipos: os que compõem o sistema de projeção estriatal direto e o indireto. A via direta é composta pelo globo pálido medial e pela substância negra pars reticulata, ambos compostos, em parte, por neurônios GABAérgicos; e a via indireta inclui conexões com o globo pálido lateral e o núcleo subtalâmico. O estriado também recebe aferência do sistema dopaminérgico nigrostriatal vinda de neurônios dopaminérgicos do mesencéfalo localizados na área tegmental ventral e na substância negra pars compacta (Paxinos, 2004).

A substância negra é composta por dois tipos principais de neurônios. Os neurônios dopaminérgicos encontram-se na sua maioria na pars compacta, região densa em neurônios, e uma minoria na pars reticulata. Nesta última se encontra a maioria dos neurônios GABAérgicos. Os neurônios dopaminérgicos da substância negra se projetam para o estriado e os GABAérgicos se projetam para o tálamo, colículo superior e núcleo pedunculopontino. Os neurônios desta região apresentam corpos celulares de formato irregular e tamanho variando de médio a grande; e possuem dois a quatro dendritos principais que se ramificam. A substância negra recebe aferências inibitórias do estriado e globo pálido lateral, e excitatória do núcleo subtalâmico. Em roedores, o principal alvo da substância negra é o tálamo ventromedial. Distúrbios de movimento como hipocinesia e hipercinesia têm sido atribuídas a desequilíbrios na atividade destas duas vias de eferência estriatal (Paxinos, 2004).

Em linhas gerais, a organização funcional dos núcleos da base se inicia com uma aferência cortical ao corpo estriado. A substância negra aferenta então o corpo estriado fazendo sinapses dopaminérgicas com neurônios que contêm GABA e encefalina para formar a alça direta, e com neurônios que contêm GABA e substância $P$ para formar a alça indireta. A alça direta retira a inibição que o globo pálido teria sobre o núcleo ventrolateral do tálamo, permitindo então que este estimule o córtex cerebral (liberando o movimento). Já a alça indireta, da qual participa o núcleo subtalâmico, produz uma inibição do tálamo e consequentemente uma estimulação reduzida do córtex (inibindo o movimento) (Kiernan, 2003) (Fig.23). Uma das funções desse sistema parece ser a de escolha e iniciação de movimentos voluntários. Entretanto, os núcleos da base participam de um grande número de circuitos paralelos, sendo apenas uns poucos de função estritamente motora (Bear et al., 2002). 


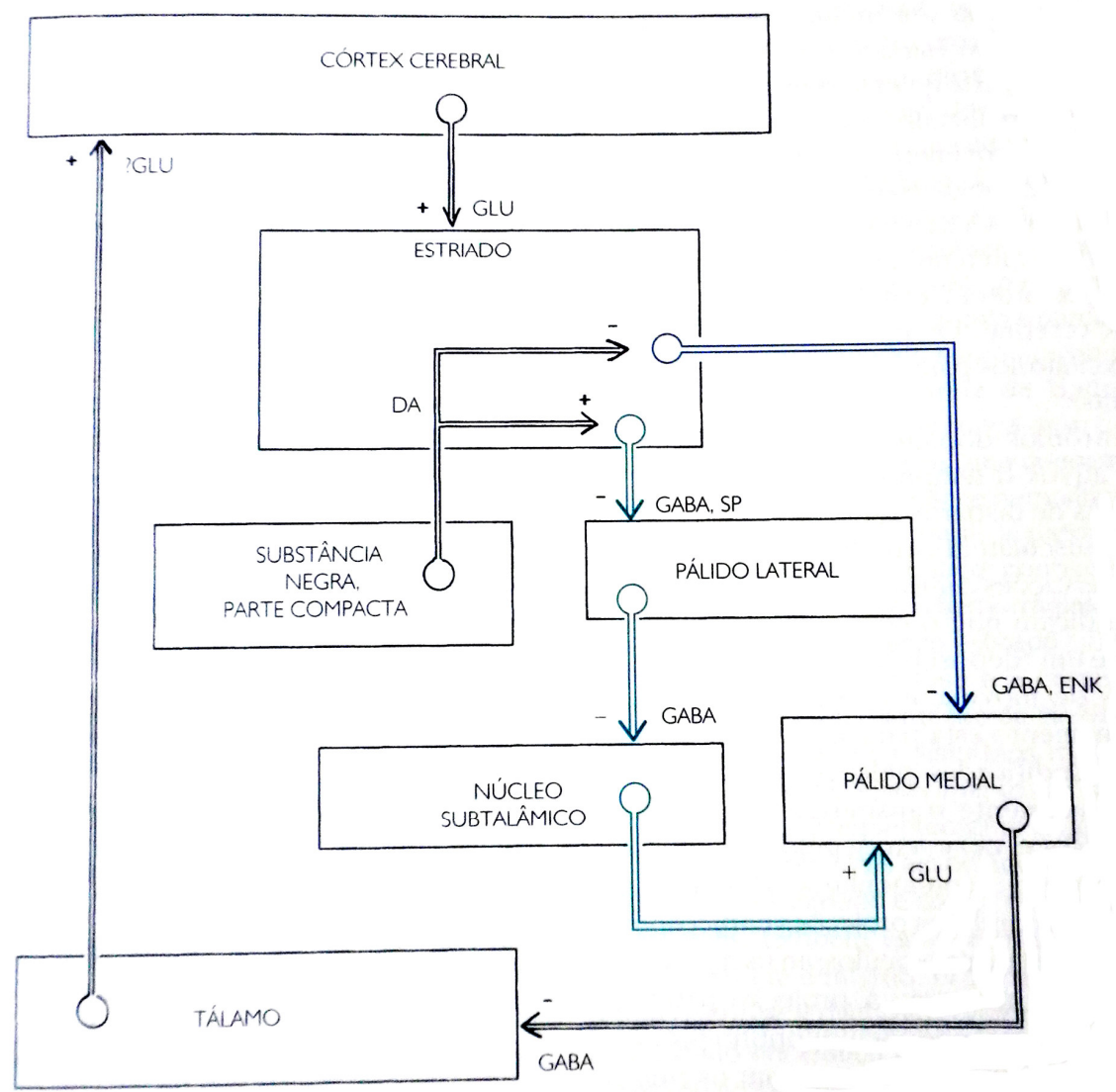

Figura 2-3. Diagrama esquemático de algumas conexões dos núcleos da base mostrando as sinapses excitatórias, inibitórias e os neurotransmissores.

FONTE: Kiernan, 2003.

\subsubsection{Córtex Motor}

O controle do movimento voluntário envolve a participação de quase todo o neocórtex. Foi o trabalho de Penfield que definiu as áreas do córtex motor humano e a organização somatotópica no giro pré-central. O córtex motor compreende, portanto, a área cortical 4 e a área cortical 6 (dividida em área pré-motora e área motora suplementar), considerada uma área motora "superior" em humanos por ser responsável por movimentos complexos (Bear et al., 2002).

$O$ isocórtex frontal representa o córtex motor do rato e é uma região arquitetonicamente heterogênea quando se refere a citoarquitetura, a mieloarquitetura, a quimioarquitetura, a utilização cerebral local de glicose e a padrões de conectividade. Esta região pode ser dividida em Fr1, Fr2 e Fr3. O Fr1 seria o córtex motor primário, o Fr3 seria uma área somatotópica e o Fr2 seria 
equivalente ao córtex pré-motor do primata, o córtex motor suplementar e a área do campo visual frontal. O padrão laminar das regiões frontais se caracteriza pela ausência de uma camada IV proeminente e pela presença de células piramidais grandes e densamente empacotadas (Paxinos, 2004).

As camadas corticais frontais apresentam distribuição heterogênea de receptores para neurotransmissores clássicos. Os receptores glutamatérgicos tipo e AMPA e NMDA apresentam densidades mais altas nas camadas I-III, enquanto que os do tipo cainato apresentam maior densidade nas camadas V-VI. Já os receptores GABAérgicos e sítios de ligação para benzodiazepínicos apresentam padrões de distribuição iguais entre as camadas nas três regiões do córtex frontal. Com relação à distribuição dos receptores colinérgicos, os receptores muscarínicos $M_{1}$ e $M_{3}$ apresentam maior densidade nas camadas I-III, enquanto que $\mathrm{M}_{2}$ é mais abundante nas camadas V-VI e os receptores nicotínicos alternam a distribuição entre as camadas, sendo mais abundante nas camadas II e V. Aparentemente, apenas o receptor noradrenérgico $\alpha_{1}$ apresenta distribuição laminar diferenciada entre as regiões frontais. O receptor $\alpha_{2 h}$ apresenta densidade mais alta nas camadas I-II e V sem diferença regional. O córtex frontal do rato possui a maior concentração de receptor $\alpha_{1}$, assim como de noradrenalina, das áreas corticais. O córtex frontal também possui a maior concentração de serotonina das áreas corticais, sendo a maior densidade de receptor para serotonina encontrada na camada $\mathrm{V}$ (Paxinos, 2004).

As principais células corticais são os células piramidais com corpos celulares de 10 a 50um e axônios longos. Cada célula piramidal possui dendritos apicais e laterais evidentes, com seus ramos cobertos por espinhas dendríticas. As células fusiformes se localizam na camada mais profunda do córtex e apresentam corpos celulares elípticos. Além das células principais, os neurônios de projeção recebem axônios das células fusiformes e transmitem impulsos aos centros subcorticais, os neurônios de associação estabelecem conexões entre outras células do mesmo hemisfério e os neurônios comissurais dirigem-se ao córtex do hemisfério oposto. Alguns dos interneurônios corticais são as células estreladas (interneurônios excitatórios da quarta camada cortical), as células em cesto (cujos axônios se ramificam e fazem contatos com o corpo celular das células piramidais), as células horizontais (encontradas na camada cortical mais superficial) e as células de 
Martinotti (dispostas mais profundamente com axônios que se projetam em direção à superfície pial) (Fig.2-4).

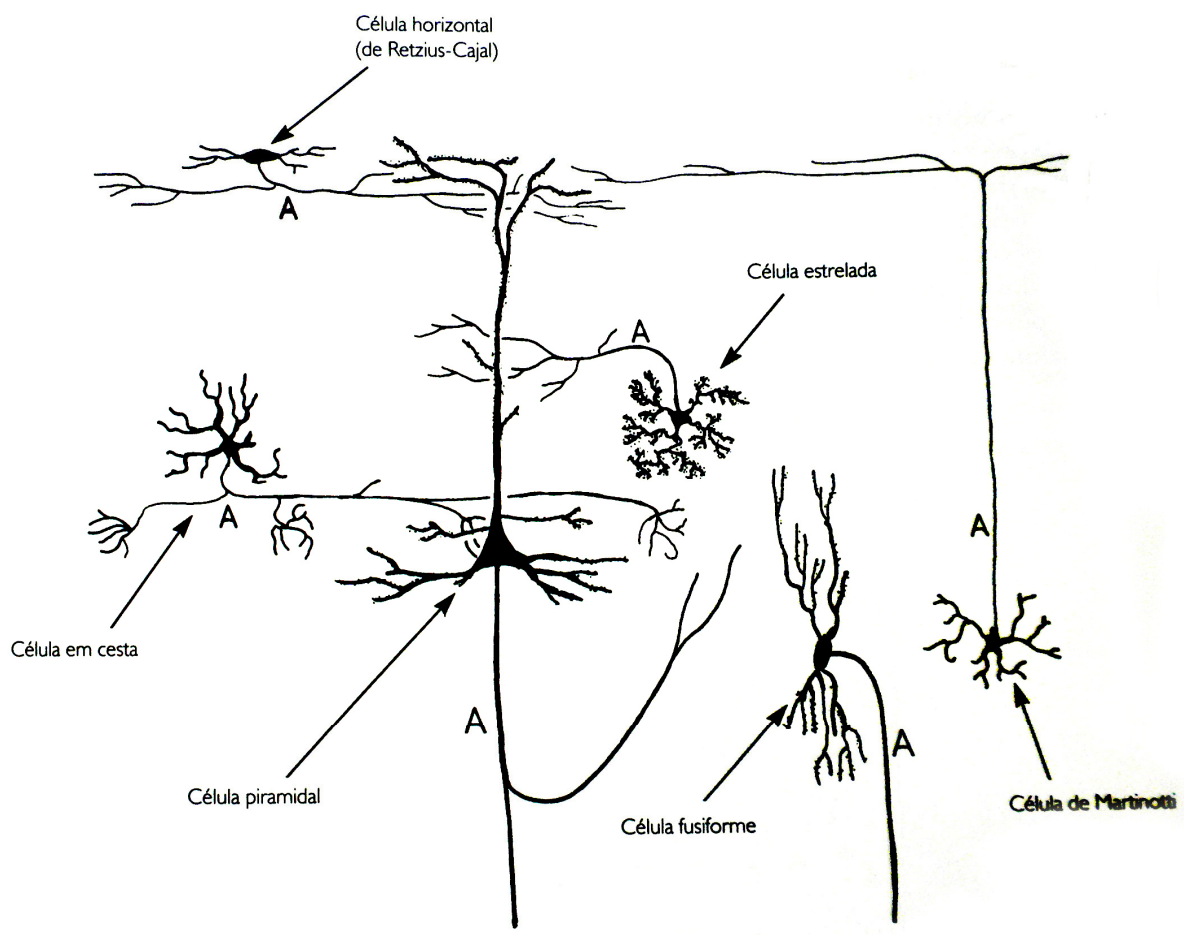

Figura 2-4. Neurônios corticais com seus dendritos simplificados e axônios indicados pela letra A. FONTE: Kiernan, 2003.

\subsubsection{Tronco Encefálico}

Pelo tronco passam todos os tratos espinais descendentes. As colunas lateral e ventromedial da medula formam as duas vias pelas quais os axônios do encéfalo descem para a medula. As vias laterais estão envolvidas com movimentos voluntários (músculos distais) enquanto que as ventromediais estão envolvidas com o contole da postura e locomoção. As vias ventromediais são controladas pelo tronco encefálico.

As vias laterais são formadas pelo trato córtico-espinhal e pelo trato rubroespinhal. O trato córtico-espinhal é o mais longo do sistema nervoso e se origina no neocórtex. Seus axônios têm origem no córtex motor (2/3) e no córtex sômatosensorial e se unem na base do bulbo formando uma protuberância ao formar o trato também conhecido com trato piramidal. Logo em seguida o trato piramidal decussa. 
O trato rubro-espinhal, por sua vez, é bem menor, tem origem no núcleo rubro do mesencéfalo e sua principal aferência é o córtex frontal. Os axônios deste trato decussam mais acima que os do trato piramidal, ainda na ponte. A partir do final do bulbo estes seguem juntos pela medula.

As vias ventromediais utilizam informações do ambiente (estímulos visuais) e do próprio corpo (equilíbrio, posição do corpo no espaço) para manter o equilíbrio e a postura. Estas vias se originam no tronco encefálico e são formadas pelos tratos vestíbulo-espinhal, tecto-espinhal, retículo-espinhal pontino e retículo-espinhal bulbar. Os tratos vestíbulo-espinhal e tecto-espinhal mantém o equilíbrio da cabeça, tendo origens nos núcleos vestibulares do bulbo e no colículo superior do mesencéfalo, respectivamente. Já os tratos retículo-espinhal pontino e bulbar têm origem na formação reticular do tronco encefálico. Estes tratos, no entanto, desempenham funções opostas: o primeiro aumenta os reflexos antigravitacionais da medula e o segundo libera os músculos antigravitacionais de controle reflexo. $O$ controle de ambos os tratos retículo-espinhais se dá por sinais descendentes oriundos do córtex e um fino equilíbrio é necessário para o controle motor (Bear et al., 2002).

A formação reticular consiste em uma porção substancial da parte posterior do tronco encefálico (Fig.2-5) onde os grupos de neurônios e feixes de fibras entrelaçados (na sua maioria) apresentam em cortes transversais um aspecto semelhante a uma rede. Os neurônios dos núcleos reticulares apresentam longos dendritos e sua arquitetura permite-lhes receber e integrar influxos sinápticos da maioria dos axônios que atravessam ou se projetam para o tronco encefálico (Kiernan, 2003). Através de suas conexões diretas ou indiretas com diversos níveis do sistema nervoso central, a formação reticular contribui para funções como a coordenação do ciclo sono-vigília (Kiernan, 2003; Lent, 2008), o controle da excitabilidade das regiões corticais (Lent, 2008), o controle do movimento e a regulação da atividade visceral (Kiernan, 2003). 


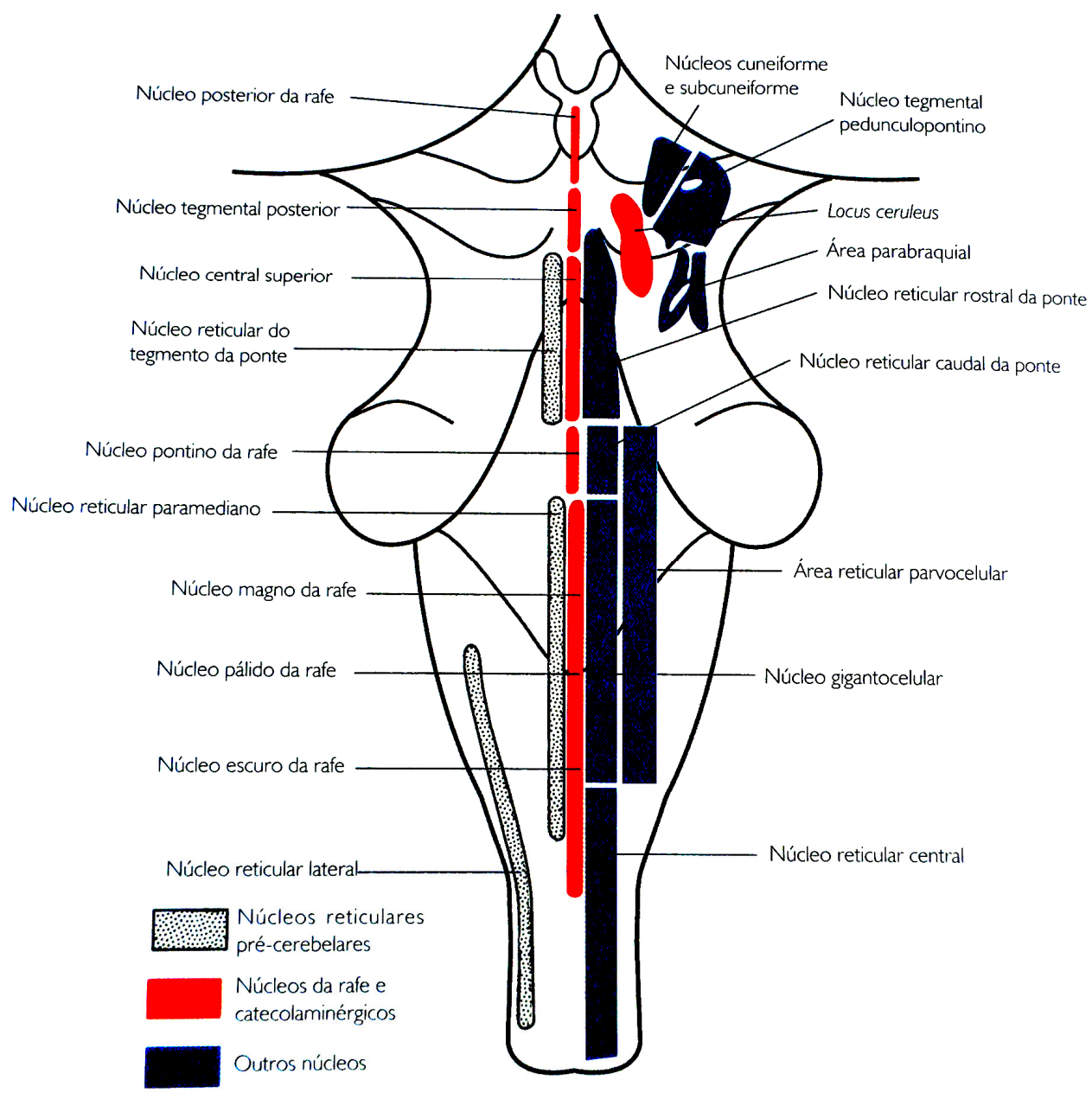

Figura 2-5. Diagrama mostrando as posições dos maiores núcleos da formação reticular do tronco encefálico.

FONTE: Kiernan, 2003.

\subsection{JUSTIFICATIVA E OBJETIVOS}

Considerando que para humanos a recomendação da prática de exercícios é de 30 minutos de atividade moderada por dia na maioria dos dias da semana (Hillman et al., 2008), usamos aqui um modelo animal de exercício moderado em esteira para investigar os efeitos deste protocolo em regiões motoras do encéfalo, comumente afetadas por doenças neurodegenerativas, e no hipocampo de ratos, região associada à memória, aprendizado e processos cognitivos. Estudar os efeitos do exercício em situações fisiológicas pode sugerir mecanismos preventivos, assim como elucidar como estes efeitos ocorrem simultaneamente nas diferentes regiões do encéfalo. Utilizamos marcadores de plasticidade como o fator neurotrófico BDNF, 
que tem sido repetidamente associado à plasticidade hipocampal induzida pelo exercício (Vaynman et al., 2003, 2004a, b, 2006; Griesbach et al., 2004b; Ding et al., 2006a), marcadores de densidade sináptica (SYN e SYP); proteínas estruturais neuronais preditoras de crescimento ou remodelamento axonal ou dendrítico (NFs e MAP2), o amplamente utilizado marcador de astrócitos GFAP, o marcador de proliferação celular BrdU, e o marcador de neurogênese DCX. Para monitorar os níveis de estresse induzidos pelo protocolo de exercício, dosamos a corticosterona plasmática.

\subsection{MATERIAL E MÉTODOS}

\subsubsection{ANIMAIS}

Foram utilizados nos experimentos ratos machos da linhagem Wistar de 2 meses de idade (pesando ca. $250 \mathrm{~g}$ ) fornecidos pelo biotério central do Instituto de Ciências Biomédicas da USP. Os animais foram mantidos em grupos de 4 em caixas de polietileno em uma sala com temperatura constante de $23^{\circ} \mathrm{C}$ e ciclo controlado claro / escuro invertido artificialmente de 12/12h, com água e alimentação ad libitum. Todos os protocolos foram aprovados pela Comissão de Ética em Experimentação Animal (CEEA) (protocolo $n^{0}$ 013/2006) e os procedimentos experimentais foram realizados de acordo com o Colégio Brasileiro de Experimentação Animal (COBEA) e o guia de cuidados com o animal do National Institutes of Health (NIH/EUA).

\subsubsection{PRotocolo DE EXERCí́cIo}

Os animais foram treinados em uma esteira ergométrica programável (KT 3000 - IMBRAMED) adaptada para ratos (Fig.2-6). A esteira é constituída de 10 raias de acrílico transparente pintadas de preto em sua extremidade anterior. A parte anterior das raias mais escura cria um ambiente para o qual os ratos são atraídos durante o treinamento, evitando a necessidade de choques elétricos.

Inicialmente todos os animais passaram por um período de adaptação à esteira por 2 dias. Após um tempo de exploração da esteira, esta era ligada por 15 minutos a uma velocidade de $0,3 \mathrm{~km} / \mathrm{h}$ nos primeiros 5 minutos, $0,4 \mathrm{~km} / \mathrm{h}$ nos 5 minutos seguintes e $0,5 \mathrm{~km} / \mathrm{h}$ nos 5 minutos finais. Os animais que apresentaram qualquer dificuldade durante o período de adaptação foram excluídos do protocolo. 
A partir deste momento os animais restantes foram divididos em 4 grupos: sedentários (S), 3 dias de exercício (EX3), 7 dias de exercício (EX7) e 15 dias de exercício (EX15). O treinamento consistiu de 40 minutos de corrida a cerca de $60 \%$ do $\mathrm{VO}_{2}$ máximo (Felix e Michelini, 2007), sendo o primeiro minuto a $0,4 \mathrm{~km} / \mathrm{h}$, o segundo minuto a $0,5 \mathrm{~km} / \mathrm{h}$ e os demais minutos a $0,6 \mathrm{~km} / \mathrm{h}(10 \mathrm{~m} / \mathrm{min}$ ) (Ferreira et al., 2010; Real et al., 2010). Com o intuito de minimizar o estresse dos animais, optamos por não realizar teste de esforço e considerar os valores de $\mathrm{VO}_{2}$ máximo já obtidos em outros projetos do nosso departamento (Felix e Michelini, 2007). Todos os treinamentos foram realizados no meio do ciclo ativo dos animais (entre $11 \mathrm{am}$ e $1 \mathrm{pm}$ ) enquanto os animais sedentários eram apenas manuseados, permanecendo em suas caixas ao lado da esteira. Durante o treinamento, os animais dos grupos experimentais que apresentaram dificuldade foram excluídos do protocolo.
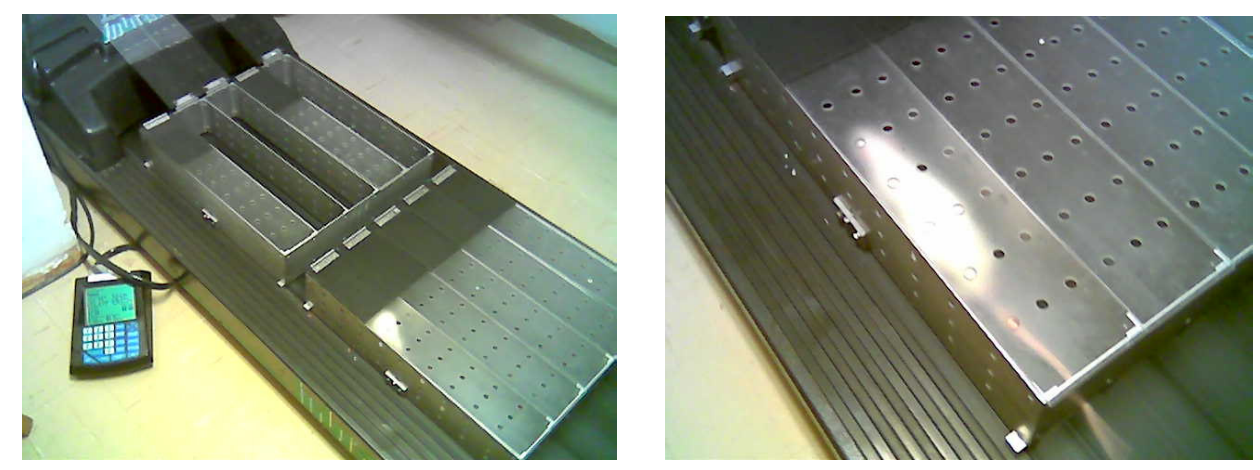

Figura 2-6. Esteira ergométrica adaptada para ratos (KT 3000 - IMBRAMED).

\subsubsection{PROTOCOLO DE IMUNO-HISTOQUímiCA}

Os animais (8 animais por grupo) foram profundamente anestesiados (ketamina, $20 \mathrm{mg} / 100 \mathrm{~g}$ de peso corporal; xilazina, $2 \mathrm{mg} / 100$, i.m.) e submetidos à perfusão transcardíaca, com $300 \mathrm{ml}$ de solução salina tamponada (PBS, $0.1 \mathrm{M}$ ), seguidos de $300 \mathrm{ml}$ de solução fixadora constituída de paraformaldeído $2 \%$ dissolvido em tampão fosfato $0,1 \mathrm{M}$ (PB, pH 7,4). Após a perfusão, os encéfalos foram coletados e pós-fixados na solução fixadora durante 4 horas a $4^{\circ} \mathrm{C}$. Após este período, o material foi transferido para uma solução contendo sacarose a $30 \%$ em PB para crioproteção a $4^{\circ} \mathrm{C}$. Após 48 horas, os tecidos foram cortados (espessura de 
$30 \mu \mathrm{m})$ em um micrótomo deslizante de congelamento e os cortes foram coletados em placa de cultivo de 6 unidades e armazenados a $4^{\circ} \mathrm{C}$.

Após três lavagens (10 minutos cada) em PB os cortes foram incubados com a seguinte série de anticorpos primários: anticorpo policlonal de coelho dirigido contra a proteína SYN (1:1000) (Chemicon, Temecula, CA, EUA), anticorpo policlonal de coelho dirigido contra a proteína SYP (1:250) (DakoCytomation, Glostrup, Dinamarca), anticorpo monoclonal de camundongo dirigido contra NFs (PAN; reconhece os neurofilamentos de 68kDa, 160kDa e 200kDa) (1:2000) (Zymed Laboratories, San Francisco, CA, EUA), anticorpo policlonal de coelho dirigido contra a proteína BDNF (1:500) (Chemicon, Temecula, CA, EUA), anticorpo monoclonal de camundongo dirigido contra a proteína MAP2 (1:1000) (Chemicon, Temecula, CA, EUA), e anticorpo monoclonal de camundongo dirigido contra a proteína GFAP (1:1000) (Immunon, Pittsburg, PA, EUA). Os anticorpos secundários biotinilados utilizados foram anti-coelho feito em cabra para o anti-SYN e o anti-BDNF, anticoelho feito em burro para o anti-SYP, anti-camundongo feito em cabra para o antiNFs e anti-camundongo feito em burro para o anti-MAP2 e o anti-GFAP (Jackson Immuno Research Lab., West Grove, Pennsylvania, EUA). Os anticorpos primários foram diluídos em PB contendo 0,3\% de Triton X-100 e 5\% de soro normal de cabra (NGS) (para anti-SYN, anti-BDNF e anti-NFs) ou soro normal de burro (NDS) (para anti-SYP, anti-MAP2 e anti-GFAP). As incubações com os anticorpos primários foram conduzidas por 14-20 horas à temperatura ambiente (ca. $24^{\circ} \mathrm{C}$ ). Após lavagens em PB ( $3 \times 10 \mathrm{~min})$, os cortes foram incubados com os respectivos anticorpos secundários diluídos a 1:200 em PB contendo 0,3\% de Triton X-100 por 2 horas à temperatura ambiente. Os cortes foram então lavados em PB (3 x 10min) e incubados com o complexo avidina-biotina-peroxidase (ABC Elite Kit, Vector Labs) por 2 horas à temperatura ambiente. Em seguida, após lavagens PB (3 x 10min), foi feita a reação com 0,05\% de 3-3'-diaminobenzidina e uma solução de peróxido de hidrogênio a 0,03\% em PB. Após mais seis lavagens em PB (10 minutos cada), os cortes foram montados em lâminas gelatinizadas, intensificados por 0,05\% de tetróxido de ósmio em água, desidratados à temperatura ambiente e cobertos com lamínulas utilizando Permount (Fisher). O material foi então analisado em microscópio óptico e imagens digitais foram coletadas e montadas com o programa Adobe Photoshop (Adobe Systems Inc., Mountain View, CA, EUA). Para confirmar a 
especificidade dos anticorpos, alguns cortes foram incubados apenas com 0 respectivo anticorpo secundário, condição na qual não observamos marcação.

\subsubsection{Protocolo de Western blotting}

Os animais (8 animais por grupo) foram decapitados e as áreas do encéfalo a serem avaliadas foram rapidamente coletadas, congeladas em nitrogênio líquido e armazenadas a $-70^{\circ} \mathrm{C}$ até o uso. As amostras foram homogeneizadas a $4^{\circ} \mathrm{C} \mathrm{em}$ tampão de extração (Tris pH 7,4 100mM, EDTA 10mM, PMSF 2mM e aprotinina 0,01 $\mathrm{mg} / \mathrm{ml}$ ). Os homogenatos foram centrifugados por 20 minutos a $12.000 \mathrm{rpm}$ em uma centrífuga refrigerada a $4^{\circ} \mathrm{C}$. O sobrenadante foi separado do "pellet", uma pequena amostra deste foi utilizada para determinação do conteúdo protéico, e o restante tratado com tampão Laemmli contendo DTT 100mM (Laemmli, 1970), fervido em banho-maria por 5 minutos e armazenada. O conteúdo protéico do material isolado dos animais foi dosado pelo método de Bradford (Amresco, U.S.A) (Bradford, 1976) utilizando um kit para ensaio de proteínas (Bio-Rad; Hercules, CA, EUA).

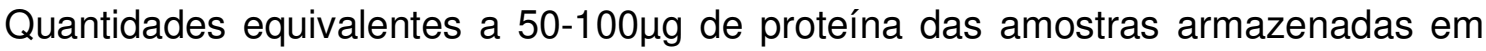
Laemmli foram submetidas à separação por eletroforese com corrente constante de $25 \mathrm{~mA}$ em géis de acrilamida de 6,5\%, $8 \%$ e 12\% contendo dodecil sulfato de sódio (SDS) (Bio-Rad, EUA) utilizando uma cuba para mini-gel (Mini-Protean 3; Bio-Rad do Brasil, Rio de Janeiro, Brasil). Após a separação eletroforética, as proteínas foram eletro-transferidas para membranas de nitrocelulose $(0,45 \mu \mathrm{m}$ de diâmetro) (Millipore) utilizando um sistema de transferência (Trans-Blot cell system; Bio-Rad) em tampão contendo SDS. Após a transferência, as membranas foram incubadas em solução de bloqueio contendo $5 \%$ de leite desnatado em salina tamponada contendo Tween 20 (TTBS: 0,01M de Tris-HCL, pH 7,4, 0,15M de $\mathrm{NaCl}, 0,05 \%$ de Tween 20) durante pelo menos 2 horas sob agitação leve. Após este período as membranas foram lavadas 3 vezes de 10 minutos com TTBS e incubadas com os mesmos anticorpos primários utilizados para imuno-histoquímica a uma concentração de 1:1000 a $4^{\circ} \mathrm{C}$, sob leve agitação, durante toda a noite. Em seguida, as membranas foram lavadas com TTBS e incubadas por 2 horas com anticorpos secundários marcado com peroxidase (Amersham; Little Chalfont, Buckinghamshire, UK) diluídos a 1:10.000 em solução contendo 1\% de leite desnatado em TTBS. Foram utilizados anti-coelho IgG -HRP para SYN, SYP e BDNF e anti-camundongo 
IgG -HRP para NFs, MAP2 e GFAP. Após lavar por 3 vezes de 10 minutos em TTBS, as membranas foram reveladas utilizando um kit quimioluminescente (ECL, Amersham Biosciences, NJ, EUA) A reação foi visualizada por meio de filmes radiográficos colocados em contato com as membranas e em seguida revelados $\mathrm{e}$ fixados. As membranas foram então incubadas com solução de stripping por 20 minutos a temperatura ambiente e um anticorpo contra $\beta$-actina (Sigma, St. Louis, $M O, E U A)$ foi utilizado para quantificar esta proteína como controle da concentração de proteína total aplicada nos géis. A intensidade das bandas marcadas foi analisada por densidade óptica utilizando o programa Scion Image 4.0.2 (Scion Corporation, Frederick, MD, EUA).

\subsubsection{Protocolo de extraçÃo do RNA total, síntese de CDNA e PCR em tempo REAL}

O RNA das estruturas coletadas (8 animais por grupo) foram extraídos a partir de 100mg de tecido, homogeneizados com Polytron® (Brinkmann, Mississauga, CAN) em $1 \mathrm{~mL}$ do Reagente TRIzol® (Invitrogen-Life Technologies, Carlsbad/CA, EUA) conforme recomendações do fabricante. Ao homogenenato foram adicionados $0,2 \mathrm{~mL}$ de clorofórmio, seguido de agitação por $15 \mathrm{~s}$ e centrifugação a $12.000 \times \mathrm{g}$ por $15 \mathrm{~min}$, a $4^{\circ} \mathrm{C}$. O RNA total presente na fase aquosa foi precipitado com isopropanol gelado, centrifugado a $10.000 \times \mathrm{g}$, por $10 \mathrm{~min}$, a $4^{\circ} \mathrm{C}$ e lavado com etanol a $70 \%$ (v/v). Em seguida, o RNA foi seco a temperatura ambiente e ressuspendido em 25 $\mu \mathrm{L}$ água estéril tratada com dietilpirocarbonato (DEPC) (Sigma, Saint Louis, MO, EUA), incubado por 10 min a $56^{\circ} \mathrm{C}$, e armazenado a $-70^{\circ} \mathrm{C}$ para posterior análise.

O RNA total isolado foi quantificado $\left(A_{260} \mathrm{~nm}\right)$ e seu grau de pureza $\left(A_{260} / A_{280 \mathrm{~nm}}\right)$ foi avaliado por espectrofotometria no UV (Biophotometer, Eppendorf, Hamburg, ALE). A integridade do RNA das amostras foi avaliada por eletroforese em gel de agarose a 1,0\%, contendo formaldeído a 2,2M e tampão MOPS (MOPS a 20 $\mathrm{mM})(\mathrm{pH} 7,0)$, acetato de sódio a $8 \mathrm{mM}$ e EDTA a $1 \mathrm{mM}(\mathrm{pH} 8,0)$ preparado com água esterilizada preparada com DEPC (Sigma, Saint Louis, MO, EUA), por 60 min a 100V (Sambrook, 2001). O gel foi corado com brometo de etídio a $0,5 \mathrm{mg} / \mathrm{mL}$ e examinado sobre luz UV em transiluminador, utilizando-se como referência um marcador de RNA (Invitrogen-Life Technologies, Carlsbad/CA, EUA). 
O equivalente a $4 \mu \mathrm{g}$ de RNA total de cada amostra foi tratado com a enzima Deoxyribonuclease I (DNAse I, Amp Grade, Invitrogen-Life Technologies, Gathersburg, MD, EUA) para remoção de DNA genômico contaminante. Em seguida, foi realizada a síntese de cDNA utilizando-se $500 \mathrm{ng}$ de oligo dT, tampão de enzima $1 \mathrm{X}$ (Tris- $\mathrm{HCl}$ a $25 \mathrm{mM} \mathrm{pH} 8,3, \mathrm{KCl}$ a $75 \mathrm{mM}$ e $\mathrm{MgCl}_{2}$ a $3 \mathrm{mM}$ ), DTT a 20 mM, dNTP a 0,5 mM e $200 \mathrm{U}$ da enzima a enzima SuperScript ${ }^{\mathrm{TM}}$ III RT (InvitrogenLife Technologies, Gathersburg, MD, EUA). O cDNA obtido foi armazenado a $-20^{\circ} \mathrm{C}$ para futura realização do PCR em tempo real .

A reação de PCR em tempo real incluiu o seguinte: 200 a $400 \mathrm{nM}$ de primers, $5 \mathrm{ng}$ de amostras de CDNA e 1X SYBR® Green PCR Master Mix (Applied Biosystems, Foster City, CA, EUA). Utilizando sistema de detecção Rotor-Gene 3000 Real-Time PCR (Corbett Research, Mortlake, NSW, Australia), os ciclos foram realizados nas seguintes condições: após ativação inicial a $50^{\circ} \mathrm{C}$ por 2 min e a $95^{\circ} \mathrm{C}$ por $10 \mathrm{~min}, 40$ ciclos a $95^{\circ} \mathrm{C}$ por 15 segundos e $60^{\circ} \mathrm{C}$ por 1 min seguidos da analise da curva de derretimento foram completados aquecendo as amostras de $65^{\circ} \mathrm{C}$ até $99^{\circ} \mathrm{C}$ (aumentos de $1^{\circ} \mathrm{C}$ a cada $5 \mathrm{~min}$ ) para avaliação da especificidade do primer. Todas as medidas das amostras foram feitas em duplicata. Os primers utilizados como controle interno (housekeeping genes), hidroximetilbilano sintase (HMBS) e hipoxantina fosforibosil transferase 1 (HPRT1), foram descritos por Depreter et al. (2002) e os primers para os genes de interesse foram desenhados através do programa Primer Express v3.0 (Applied Biosystems). A eficiência dos primers utilizados variou de 98 a $118 \%(106 \pm 7 \%)$ e suas propriedades estão descritas na Tabela 1.

A quantificação relativa dos genes de interesse foi conduzida utilizando o método do CT comparativo, como descrito em detalhes em Medhurst et al. (2000). O valor do $\triangle \mathrm{CT}$ foi determinado subtraindo os valores do CT de cada amostra da média dos respectivos valores do CT dos housekeeping genes. O cálculo do $\Delta \Delta \mathrm{CT}$ se deu pela subtração de cada $\Delta \mathrm{CT}$, da constante arbitrária determinada pelo cálculo da média dos valores de $\triangle \mathrm{CT}$ do grupo sedentário. As mudanças na expressão gênica dos genes de interesse são equivalentes a $2^{-\Delta \Delta C T}$. 
Tabela 1 - Descrição dos primers utilizados para estudar os genes de interesse e os housekeeping genes*.

\begin{tabular}{|c|c|c|c|}
\hline Gene & Refseq & Sequência dos Primers (5’ a 3’) & $\begin{array}{l}\text { Comprimento } \\
\text { do Amplicon } \\
\text { (bp) }\end{array}$ \\
\hline NF68 & NM_031783.1 & $\begin{array}{l}\text { FW: AGA CAT CAG CGC CAT GCA } \\
\text { RV:TTC GTG CTT CGC AGC TCA T }\end{array}$ & 60 \\
\hline NF160 & NM_017029.1 & $\begin{array}{l}\text { FW: GGC TCC AGA CAT TGT ATT TTC CTT } \\
\text { RV: GGC ACC CTG AGC TTG CAT }\end{array}$ & 63 \\
\hline NF200 & NM_012607.2 & $\begin{array}{l}\text { FW: AGA GGA GTG GTT CCG AGT GAG A } \\
\text { RV: GCG CAT AGC ATC CGT GTT C }\end{array}$ & 70 \\
\hline SYN & $\begin{array}{l}\text { NM_001110782.1 } \\
\text { and NM_019137.1 }\end{array}$ & $\begin{array}{l}\text { FW: TTC AGC ATG GCA CGT AAT GG } \\
\text { RV: CCA GCA TAC TGC AGC CCA AT }\end{array}$ & 59 \\
\hline SYP & NM_012664.1 & $\begin{array}{l}\text { FW: CCC TTC AGG CTG CAC CAA } \\
\text { RV: TTG GTA GTG CCC CCT TTG AC }\end{array}$ & 62 \\
\hline BDNF & NM_007540.4 & $\begin{array}{l}\text { FW: CAC TTT TGA GCA CGT GAT CGA } \\
\text { RV: CGT TGG GCC GAA CCT TCT }\end{array}$ & 59 \\
\hline MAP2 & NM_013066.1 & $\begin{array}{l}\text { FW: AGA TCA GAA AGA CTG GTT CAT CGA } \\
\text { RV: CAG CTA AAC CCC ATT CAT CCT T }\end{array}$ & 65 \\
\hline GFAP & NM_017009.2 & $\begin{array}{l}\text { FW: CCT TGA CCT GCG ACC TTG AG } \\
\text { RV: GCG CAT TTG CCT CTC CAA }\end{array}$ & 62 \\
\hline HMBS* & NM_013168 & $\begin{array}{l}\text { FW: TCT AGA TGG CTC AGA TAG CAT GCA } \\
\text { RV: TGG ACC ATC TTC TTG CTG AAC A }\end{array}$ & 76 \\
\hline HPRT1* & X62085 & $\begin{array}{l}\text { FW: GCG AAA GTG GAA AAG CCA AGT } \\
\text { RV: GCC ACA TCA ACA GGA CTC TTG TAG }\end{array}$ & 76 \\
\hline \multicolumn{4}{|c|}{$\begin{array}{l}\text { NF68: neurofilamento 68kDa; NF160: neurofilamento 160kDa; NF200: neurofilamento 200kDa; SYN: } \\
\text { sinapsina I; SYP: sinaptofisina; BDNF: brain-derived neurotrophic factor; MAP2: proteína associada } \\
\text { ao microtúbulo 2; GFAP: proteína glial fibrilar ácida; HMBS: hidroximetilbilano sintase; HPRT1: } \\
\text { hipoxantina fosforibosil transferase 1. }\end{array}$} \\
\hline
\end{tabular}

\subsubsection{Protocolo PARA AVALIAÇÃo dE NEUROGÊNESE HIPOCAMPAL ADULTA}

Animais do grupo sedentário e 3 dias de corrida (6 animais por grupo) foram injetados intraperitonealmente após a última sessão de exercício com uma dose de $50 \mathrm{mg} / \mathrm{kg}$ de BrdU (5-bromo-2'-deoxyuridine) (Amersham Cell Proliferation Kit, Little Chalfont, Buckinghamshire, UK) dissolvido a $50 \mathrm{mg} / \mathrm{mL}$ em água deionizada. $\mathrm{O} \mathrm{BrdU}$ é análogo à timidina, que marca o DNA durante fase $\mathrm{S}$ do ciclo celular (Azizi e Vendrame, 2007). Três horas após receberem a injeção os animais treinados e 
controles foram anestesiados e submetidos à perfusão transcardíaca como descrito acima. Após três lavagens (10 minutos cada) em PBST (salina tamponada com $0,1 \%$ Triton $\mathrm{X}-100$ ), os cortes de $30 \mu \mathrm{m}$ foram submetidos à metodologia de imunoperoxidase para detecção de BrdU. $O$ material foi inicialmente tratado/denaturado com $2 \mathrm{~N} \mathrm{HCl}$ por 1 hora. Após 3 lavagens de 10 minutos cada em PBST, o material foi tratado com tetraborato de sódio $\left(\mathrm{Na}_{2} \mathrm{~B}_{4} \mathrm{O}_{7}\right) 0,1 \mathrm{M}$ a $4^{\circ} \mathrm{C}$ por 10 minutos e lavado com PBST ( $3 \times 10 \mathrm{~min}$ ) (Girardi et al., 2002). Os cortes foram então incubados com o anticorpo monoclonal anti-BrdU de camundongo diluído a 1:1000 em PBST e soro normal de burro a 5\%. As incubações com os anticorpos primários foram conduzidas por 14-20 horas à temperatura ambiente. Após três lavagens em PBST $(3 \times 10 \mathrm{~min})$, os cortes foram incubados com anticorpo secundário anticamundongo feito em burro (Jackson Immuno Research Lab., Pennsylvania, EUA) diluído a 1:200 em PBST por 2 horas.

Para marcação de DCX, os cortes foram pre-incubados em soro normal de burro a $10 \%$ e incubados por 48 horas a tamperatura ambiente com o anticorpo policlonal anti-DCX de cabra diluído a 1:100 (Santa Cruz Biotechnology, Inc., Santa Cruz, CA, EUA) e soro normal de burro a 10\%. Após três lavagens em PB ( $3 \times$ $10 \mathrm{~min}$ ), os cortes foram incubados por 2 horas com anticorpo secundário anti-cabra feito em burro (Jackson Immuno Research Lab., Pennsylvania, EUA) diluído a 1:200.

O protocolo de imunoperoxidade seguiu como descrito acima. O material foi analisado em microscópio óptico e imagens digitais coletadas e montadas com o programa Adobe Photoshop (Adobe Systems Inc., Mountain View, CA, EUA). Células da SGZ positivas para BrdU e do DG positivas para DCX foram contadas em áreas de $54.000 \mu \mathrm{m}^{2}$ a partir de $5-7$ cortes ( 3 a $4 \mathrm{~mm}$ posterior ao bregma) (Paxinos e Watson, 2005) de cada animal com o programa Image J (NIH/EUA).

Para identificar a colocalização destes dois marcadores, os cortes foram préincubados com soro normal de burro a $10 \%$ por 1 hora, incubados com anticorpo monoclonal anti-BrdU de camundongo conjugado com Alexa Fluor 488 (Caltag Laboratories, Invitrogen Corporation, Carlsbad, CA, EUA) por 14-20 horas a temperatura ambiente e com o anticorpo policlonal anti-DCX de cabra diluído a 1:100 (Santa Cruz Biotechnology, Inc., Santa Cruz, CA, EUA) e soro normal de burro a $10 \%$ por 48 horas a temperatura ambiente. Após três lavagens em PB ( $3 \times 10 \mathrm{~min})$, os cortes foram incubados por 2 horas com anticorpo secundário anti-cabra feito em burro conjugado com TRITC (Jackson Immuno Research Lab., Pennsylvania, EUA) 
diluído a 1:50. Imagens digitais foram obtidas utilizando uma objetiva de imersão em óleo (40X) em um microscópio confocal invertido (Zeiss Axiovert LSM510 - Carl

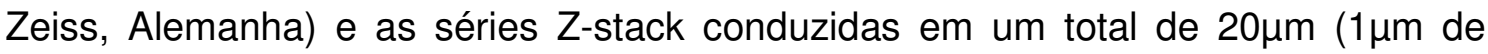
intervalo).

\subsubsection{DOSAGEM DE CORTISOSTERONA}

Para a dosagem de corticosterona plasmática, os animais ( $\mathrm{n}=8$ por grupo) foram decapitados e o sangue coletado em vacutainers contendo heparina sódica. As amostras foram centrifugadas a 1.000 x g por 15 min a $4^{\circ} \mathrm{C}$ para separação do plasma. As amostras de plasma foram armazenadas a $-70^{\circ} \mathrm{C}$ até o momento da dosagem hormonal com kit ELISA (500651 Corticosterone EIA kit - Cayman Chemical Co., Ann Arbor, MI, EUA). Todas as amostras foram processadas em duplicata e diluídas a 1:10. Os métodos utilizados aqui foram descritos por Pradelles et al. (1985).

\subsubsection{ANÁlise EStATística}

Os dados foram expressos como média „SEM. A análise estatística foi realizada utilizando ANOVA de uma via associada ao pós-teste de Tukey para os dados de proteínas, RNAm e contagem de células BrdU- e DCX-positivas, e ANOVA de uma via associada ao pós-teste de Bonferroni para a dosagem de corticosterona plasmática. Foram considerados estatisticamente significantes valores de $p<0,05$.

\subsection{RESULTADOS}

\subsubsection{Dosagem de Corticosterona}

Os resultados das medidas dos níveis plasmáticos de corticosterona revelaram aumentos em EX3 (ca. 73\%, 3742 4431 pg/ml, p<0,05) e EX7 (ca. 174\%, $5901 \pm 721 \mathrm{pg} / \mathrm{ml}, \mathrm{p}<0,01)$, enquanto que os níveis em EX15 encontravam-se semelhantes aos do grupo sedentário $(2151 \pm 276 \mathrm{pg} / \mathrm{ml})$. 


\subsubsection{HIPOCAMPO}

Nossos dados de imuno-histoquímica no hipocampo revelaram um padrão de marcação puntiforme-granular para os anticorpos anti-SYN e anti-SYP. O anticorpo contra SYN marcou intensamente o hilo do DG, enquanto que o anticorpo contra SYP gerou um padrão de marcação menos denso com apenas alguns corpos celulares marcados no hilo. Para o anti-NFs, observamos um padrão de marcação ao longo dos axônios principalmente na camada polimórfica e alguma marcação na camada molecular, enquanto que o anti-MAP2 marcou a neurópila em todas as regiões do DG. O anticorpo contra GFAP também produziu um padrão de marcação bastante difuso, marcando processos astrocitários ao longo de todo o DG. Por outro lado, o anticorpo contra BDNF marcou basicamente corpos celulares nas camadas polimórfica e granular. Foi possível observar, através de uma análise subjetiva, aumentos da imunorreatividade para NFs e MAP2 em EX3, para SYN em EX7 e para GFAP em EX15. As imunorreatividades para SYP e BDNF, no entanto, não revelaram alterações notáveis após o exercício. Na Figura 2-7 encontram-se imagens digitais representativas do grupo sedentário e do grupo experimental que revelou maior alteração da imunorreatividade para cada anticorpo.

Os dados do Western blotting no hipocampo revelaram aumentos nos níveis protéicos de NF68 e MAP2 em EX3 $(p<0,05)$, de SYN em EX7 $(p<0,05)$ e de GFAP em EX15 ( $p<0,01)$ (Fig.2-8). As análises de PCR em tempo real, contudo, revelaram apenas um aumento na expressão do RNAm para MAP2 em EX7 ( $p<0,05)$ (Fig.2-9). Não foi possível observar alterações significativas para os transcritos dos demais genes utilizados. Os resultados das análises dos níveis protéicos e da expressão dos RNAm encontram-se resumidos na Tabela 2. 


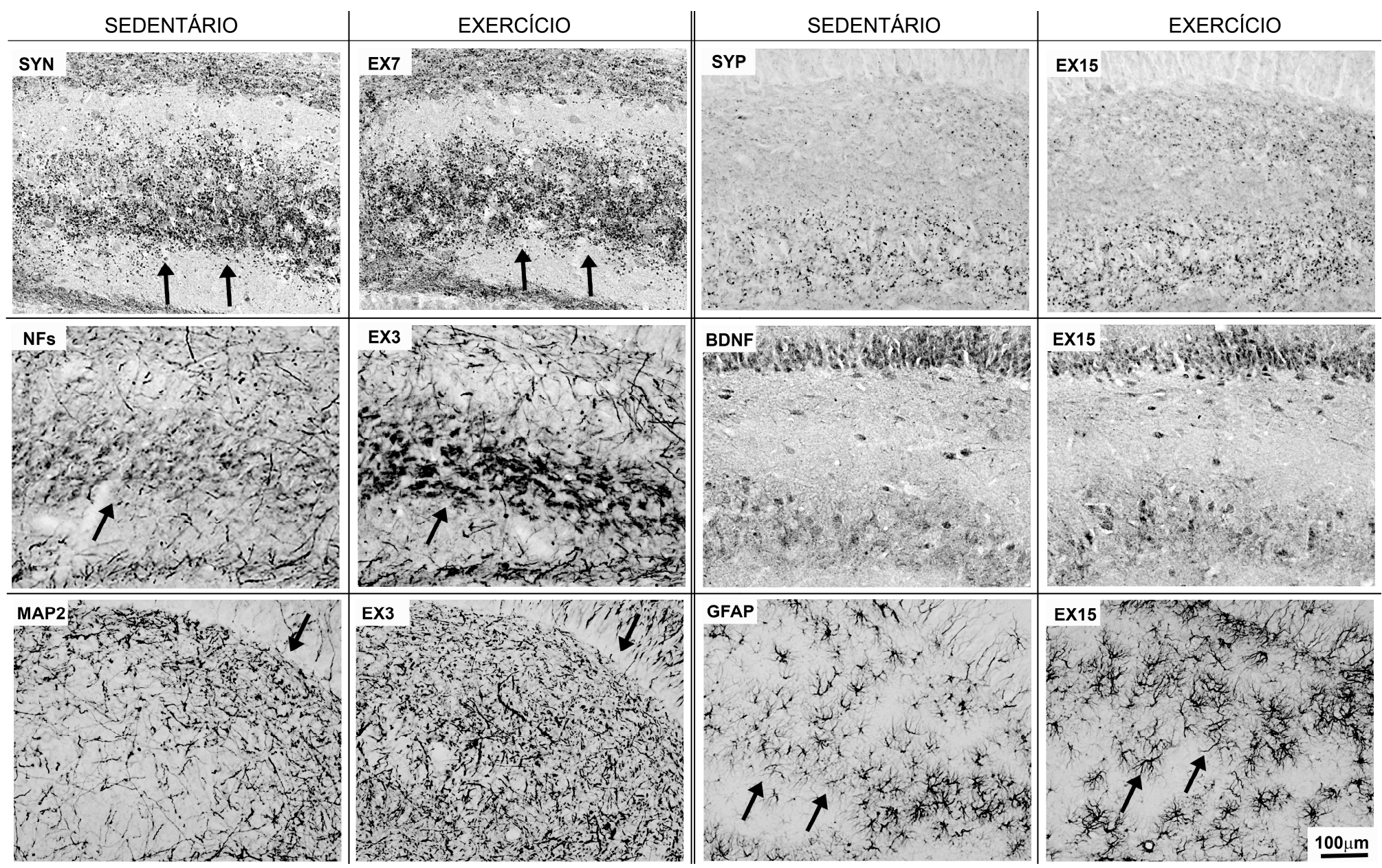

Figura 2-7. Imagens digitais de cortes coronais de encéfalo de rato ilustrando o padrão de marcação para SYN, SYP, BDNF, NFs, MAP2 e GFAP no hipocampo. É possível observar aumentos da imunorreatividade para SYN, NFs, MAP2 e GFAP (setas). 
A

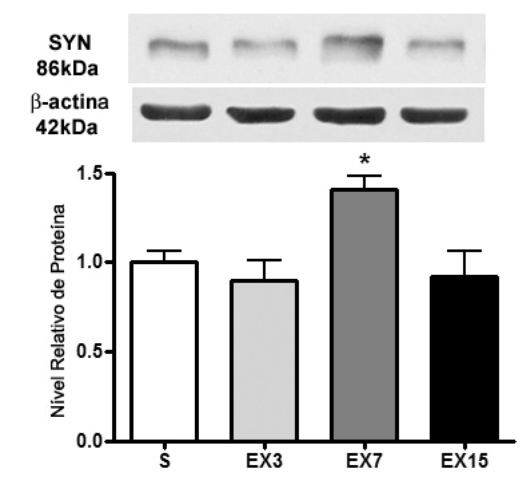

C

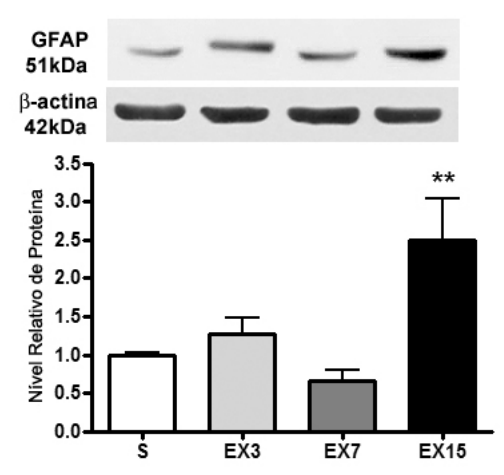

B

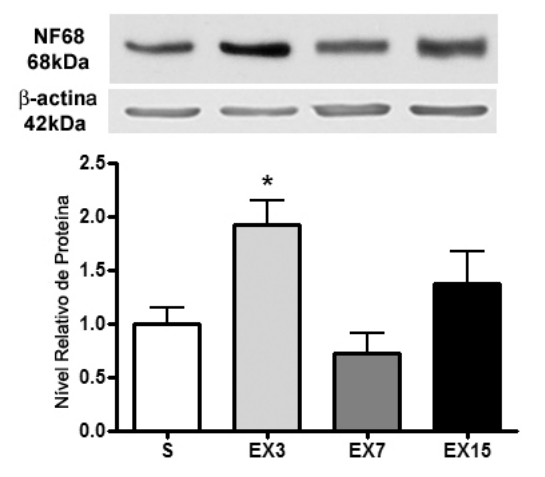

D

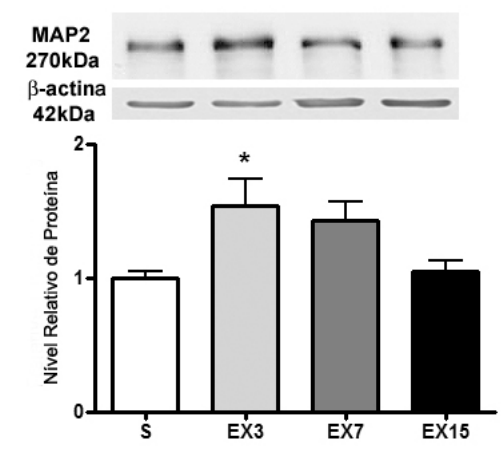

Figura 2-8. Efeitos do exercício sobre as proteínas SYN (A), NF68 (B), GFAP (C) e MAP2 (D) no hipocampo. Os gráficos representam a média da razão entre a densidade óptica das bandas das proteínas de interesse e da $\beta$-actina. Os dados estão normalizados pelos respectivos grupos sedentários e as bandas ilustradas são exemplos típicos de cada immunoblot. S: sedentário; EX3: 3 dias de exercício; EX7: 7 dias de exercício; EX15: 15 dias de exercício; SYN: sinapsina I; NF68: neurofilamento 68kDa; MAP2: proteína associada ao microtúbulo 2; GFAP: proteína glial fibrilar ácida ( ${ }^{*} p<0,05$; ${ }^{\star *} p<0,01$ vs. grupo sedentário).

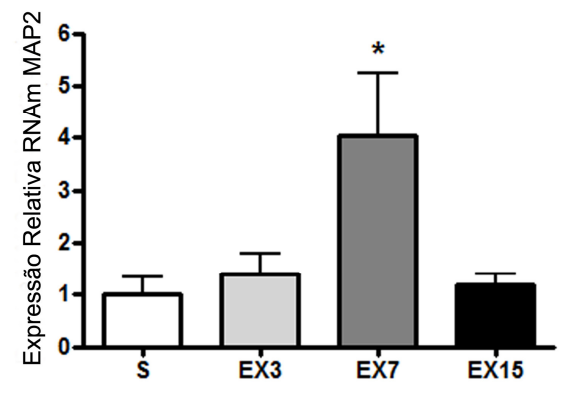

Figura 2-9. $\quad$ Efeitos do exercício sobre a expressão do RNAm para MAP2 no hipocampo. Expressão relativa do RNAm para MAP2 em cada condição é relativa ao grupo sedentário (normalizado). S: sedentário; EX3: 3 dias de exercício; EX7: 7 dias de exercício; EX15: 15 dias de exercício; MAP2: proteína associada ao microtúbulo 2 ( ${ }^{*} p<0,05$ vs. grupo sedentário). 
Tabela 2 - Níveis protéicos e de RNAm dos elementos sinápticos e estruturais no hipocampo após diferentes tempos de exercício moderado.

\begin{tabular}{|c|c|c|c|c|c|c|c|c|}
\hline \multirow{3}{*}{ PROTEÍNA } & \multicolumn{4}{|c|}{ WESTERN BLOTTING } & \multicolumn{4}{|c|}{ PCR em tempo real } \\
\hline & $\mathbf{S}$ & EX3 & EX7 & EX15 & $\mathbf{S}$ & EX3 & EX7 & EX15 \\
\hline & $\begin{array}{l}\text { MÉDIA } \\
( \pm \text { SEM) }\end{array}$ & $\begin{array}{l}\text { MÉDIA } \\
( \pm \text { SEM) }\end{array}$ & 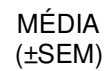 & $\begin{array}{l}\text { MÉDIA } \\
( \pm \text { SEM) }\end{array}$ & $\begin{array}{l}\text { MÉDIA } \\
( \pm \text { SEM) }\end{array}$ & $\begin{array}{l}\text { MÉDIA } \\
\text { ( } \pm \text { SEM })\end{array}$ & $\begin{array}{l}\text { MÉDIA } \\
( \pm \text { SEM) }\end{array}$ & $\begin{array}{l}\text { MÉDIA } \\
\text { (士SEM) }\end{array}$ \\
\hline SYN & $1( \pm 0,06)$ & $\begin{array}{c}0,89 \\
( \pm 0,12)\end{array}$ & $\begin{array}{c}1,41 \\
( \pm 0,07) *\end{array}$ & $\begin{array}{c}0,92 \\
( \pm 0,14)\end{array}$ & $1( \pm 0,79)$ & $\begin{array}{c}2,27 \\
( \pm 0,83)\end{array}$ & $\begin{array}{c}2,49 \\
( \pm 0,52)\end{array}$ & $\begin{array}{c}1,52 \\
( \pm 0,47)\end{array}$ \\
\hline SYP & $1( \pm 0,10)$ & $\begin{array}{c}1,18 \\
( \pm 0,11)\end{array}$ & $\begin{array}{c}1,10 \\
( \pm 0,16)\end{array}$ & $\begin{array}{c}0,96 \\
( \pm 0,16)\end{array}$ & $1( \pm 1,88)$ & $\begin{array}{c}5,62 \\
( \pm 2,68)\end{array}$ & $\begin{array}{c}4,59 \\
( \pm 1,14)\end{array}$ & $\begin{array}{c}2,76 \\
( \pm 1,15)\end{array}$ \\
\hline BDNF & $1( \pm 0,03)$ & $\begin{array}{c}0,94 \\
( \pm 0,08)\end{array}$ & $\begin{array}{c}1,06 \\
( \pm 0,11)\end{array}$ & $\begin{array}{c}0,77 \\
( \pm 0,07)\end{array}$ & $1( \pm 0,07)$ & $\begin{array}{c}1,1 \\
( \pm 0,11)\end{array}$ & $\begin{array}{c}1,16 \\
( \pm 0,10)\end{array}$ & $\begin{array}{c}1,12 \\
( \pm 0,10)\end{array}$ \\
\hline NF68 & $1( \pm 0,15)$ & $\begin{array}{c}1,92 \\
( \pm 0,23) \text { * }\end{array}$ & $\begin{array}{c}0,72 \\
( \pm 0,18)\end{array}$ & $\begin{array}{c}1,37 \\
( \pm 0,31)\end{array}$ & $1( \pm 0,20)$ & $\begin{array}{c}1 \\
( \pm 0,24)\end{array}$ & $\begin{array}{c}1,29 \\
( \pm 0,11)\end{array}$ & $\begin{array}{c}0,98 \\
( \pm 0,12)\end{array}$ \\
\hline NF160 & $1( \pm 0,07)$ & $\begin{array}{c}1,05 \\
( \pm 0,09)\end{array}$ & $\begin{array}{c}0,96 \\
( \pm 0,08)\end{array}$ & $\begin{array}{c}0,80 \\
( \pm 0,14)\end{array}$ & $1( \pm 0,09)$ & $\begin{array}{c}1,13 \\
( \pm 0,08)\end{array}$ & $\begin{array}{c}1,11 \\
( \pm 0,09)\end{array}$ & $\begin{array}{c}1,14 \\
( \pm 0,09)\end{array}$ \\
\hline NF200 & nd & nd & nd & nd & $1( \pm 0,16)$ & $\begin{array}{c}0,93 \\
( \pm 0,15)\end{array}$ & $\begin{array}{c}1 \\
( \pm 0,09)\end{array}$ & $\begin{array}{c}0,88 \\
( \pm 0,13)\end{array}$ \\
\hline MAP2 & $1( \pm 0,04)$ & $\begin{array}{c}1,54 \\
( \pm 0,20) \text { * }\end{array}$ & $\begin{array}{c}1,43 \\
( \pm 0,14)\end{array}$ & $\begin{array}{c}1,04 \\
( \pm 0,08)\end{array}$ & $1( \pm 0,33)$ & $\begin{array}{c}1,41 \\
( \pm 0,38)\end{array}$ & $\begin{array}{c}4,04 \\
( \pm 1,19) \text { * }\end{array}$ & $\begin{array}{c}1,18 \\
( \pm 0,21)\end{array}$ \\
\hline GFAP & $1( \pm 0,03)$ & $\begin{array}{c}1,27 \\
( \pm 0,21)\end{array}$ & $\begin{array}{c}0,66 \\
( \pm 0,13)\end{array}$ & $\begin{array}{c}2,49 \\
( \pm 0,55) \text { ** }\end{array}$ & $1( \pm 1,02)$ & $\begin{array}{c}2,68 \\
( \pm 1,05)\end{array}$ & $\begin{array}{c}3,44 \\
( \pm 0,58)\end{array}$ & $\begin{array}{c}2,77 \\
( \pm 1,01)\end{array}$ \\
\hline
\end{tabular}

S: sedentário; EX3: 3 dias de exercício; EX7: 7 dias de exercício; EX15: 15 dias de exercício; SYN: sinapsina I; SYP: sinaptofisina; BDNF: brain-derived neurotrophic factor; NF68: neurofilamento 68kDa; NF160: neurofilamento 160kDa; NF200: neurofilamento 200kDa; MAP2: proteína associada ao microtúbulo 2; GFAP: proteína glial fibrilar ácida; nd: não detectado $\left({ }^{*} p<0,05 ;{ }^{* \star} p<0,01 ;{ }^{* \star *}\right.$ $p<0,001$ vs. grupo sedentário).

\subsubsection{Neurogênese no hipocampo adulto}

$\mathrm{Na}$ análise dos níveis de proliferação celular na SGZ pela marcação por BrdU, observamos que o número de células marcadas aumentou significativamente em EX3 $(p<0,01)$, atingiu pico em EX7 $(p<0,001)$ e manteve-se aumento em EX15 $(p<0,05)$, porém com números menores que os tempos de corrida anteriores, como ilustrado na Figura 2-10 A e B. Já a análise do marcador de neurogênese, DCX, revelou um aumento progressivo do número de células marcadas $(p<0,001)$, sugerendo um aumento da proporção de fenótipo neuronal nestes grupos (Fig 2-10 C e D). Foi observada também a colocalização de uma parte das células marcadas para estes anticorpos como evidenciado pelas setas na Figura 2-10 E. 
A

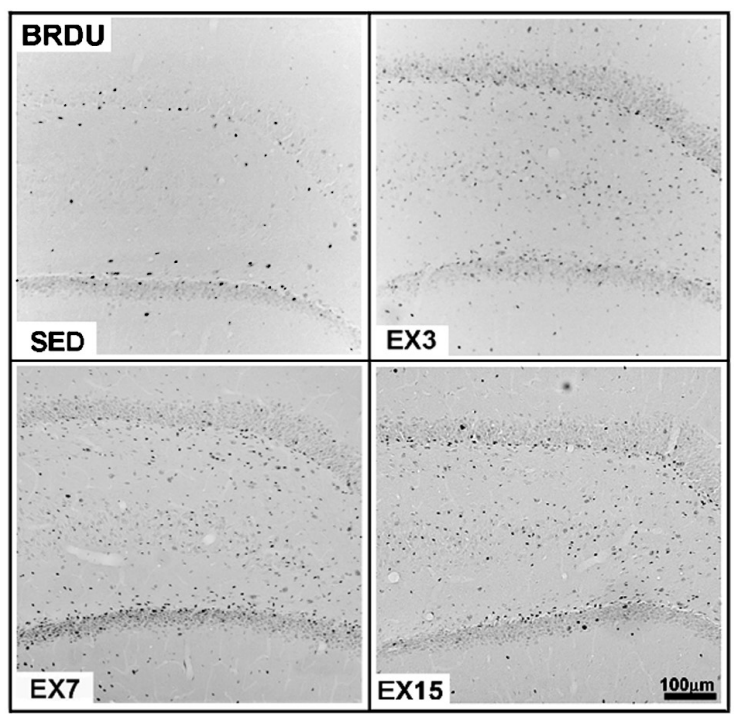

B

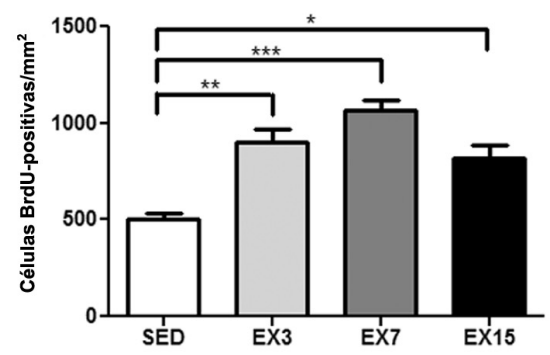

C

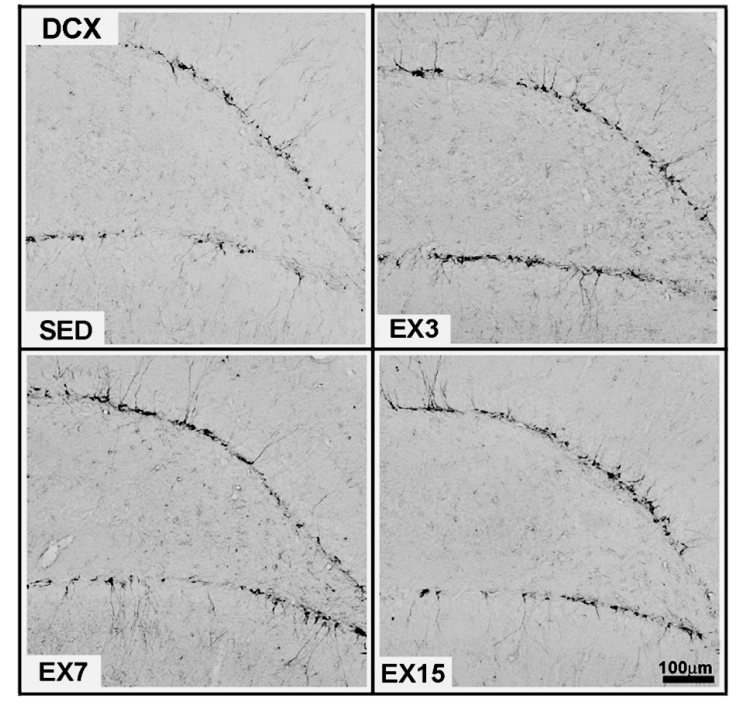

D

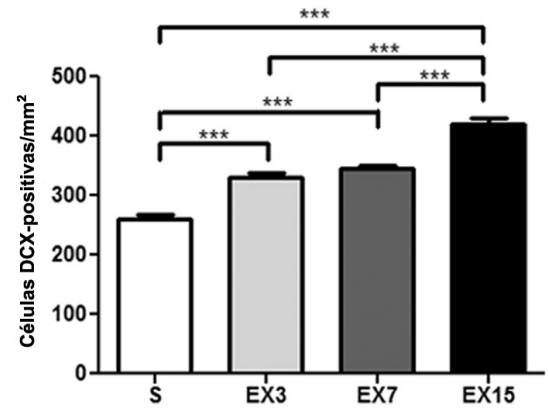

$\mathbf{E}$
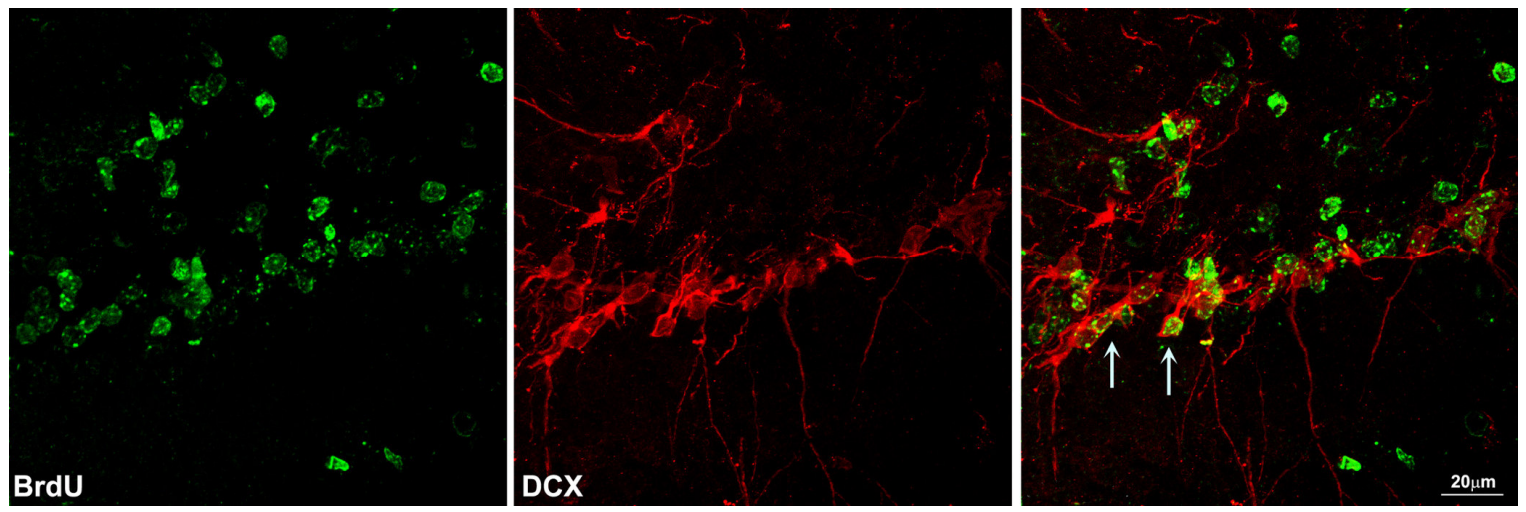

Figura 2-10. Efeitos do exercício sobre a proliferação celular e neurogënese no hipocampo. (A) Imagens digitais de cortes coronais de encéfalo de rato marcados para (A) BrdU e (C) DCX no giro denteado do hipocampo. (B) Número de células positivas para BrdU por $\mathrm{mm}^{2}$ na zona subgranular. (D) Número de células positivas para DCX por $\mathrm{mm}^{2}$ no giro denteado. (E) Z-Stack de $20 \mu \mathrm{m}$ de cortes coronais de encéfalo de rato ilustrando a colocalização entre as marcações para BrdU e DCX na imagem projetada (setas). BrdU: 5-bromo-2-deoxyuridine; DCX: doublecortin; S: sedentário; EX3: 3 dias de exercício ( ${ }^{* \star \star} p<0,001$ vs. grupo sedentário). 


\subsubsection{Regiões Motoras}

Para o estudo das regiões motoras, focamos nos efeitos do exercício sobre as proteínas de vesícula SYN e SYP e sobre os NFs. Nossos resultados das análises de imuno-histoquímica para SYN e SYP mostraram um padrão de marcação citoplasmático assim como um padrão puntiforme-granular em regiões de maior densidade sináptica e a marcação para NFs foi mais visível ao longo de processos, como se pode observar na Figura 2-11. Uma vez que a técnica de imunohistoquímica é considerada como semi-quantitativa, optamos por realizar uma análise subjetiva dos efeitos do exercício moderado sobre a imunorreatividade produzida pelos anticorpos aqui utilizados. Contudo, foi possível observar diferenças da imunorreatividade em diversas situações, como se pode observar nas imagens representativas das figuras que seguem. Apenas os dados do Western blotting e do PCR em tempo real foram, portanto, utilizados para avaliar quantitativamente os resultados dos diferentes grupos nas diferentes regiões do encéfalo que serão descritas a seguir. Estes resultados encontram-se resumidos na Tabela 3 onde os resultados descritos para o Western blotting são densidades ópticas relativas (proteína de interesse/ $\beta$-actina) e os valores para o PCR em tempo real correspondem a expressão relativa de RNAm (genes de interesse/housekeeping genes). Todos os valores e significâncias apresentados são referentes ao grupo sedentário. 


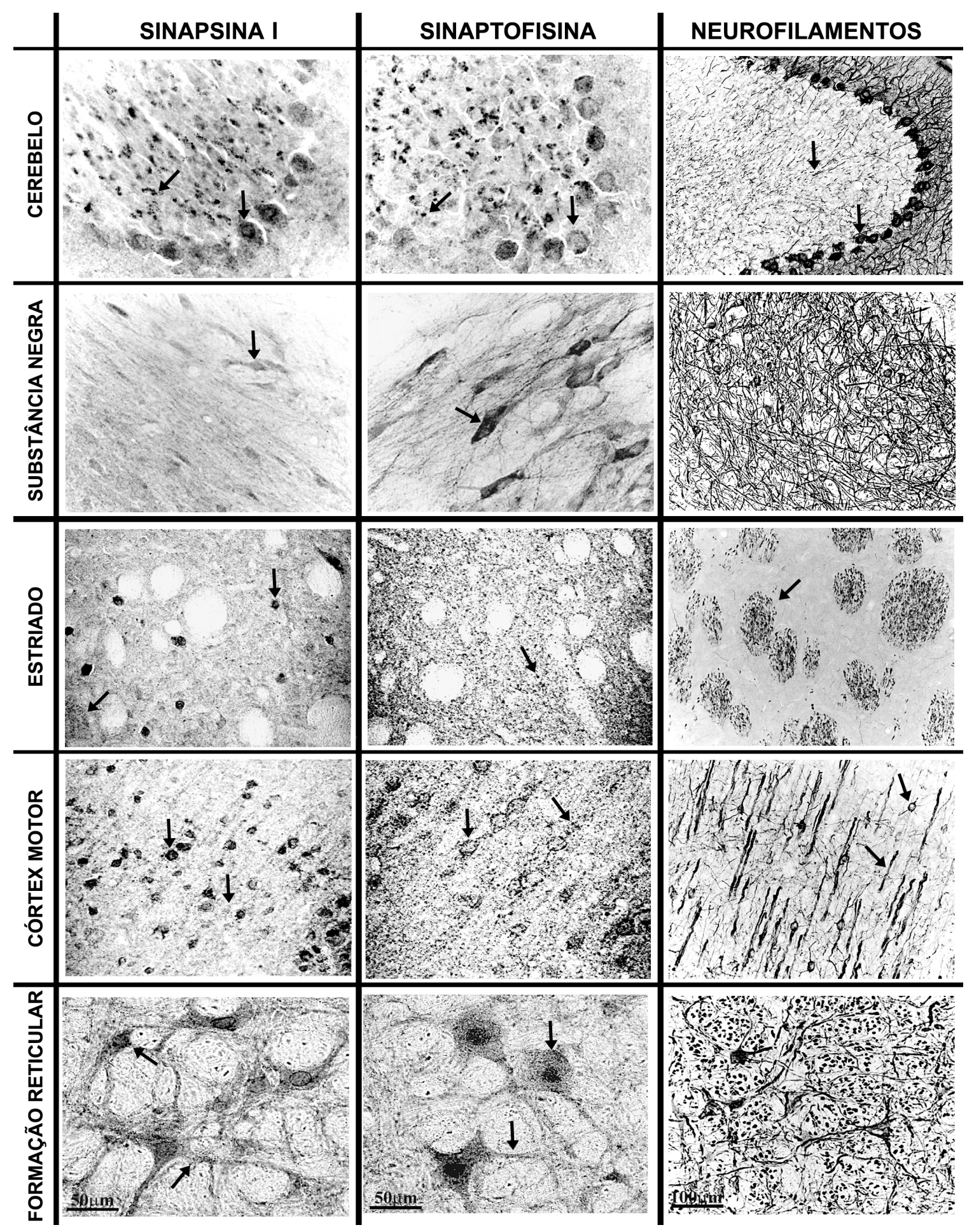

Figura 2-11. Imagens digitais de cortes coronais de encéfalo de rato ilustrando o padrão de marcação descrito no texto (setas) para sinapsina, sinaptofisina e neurofilamentos na folha cerebelar, substância negra, estriado rostral, córtex motor primário e formação reticular do tronco encefálico. 


\subsubsection{Cerebelo}

No cerebelo, todos os anticorpos utilizados produziram um padrão citoplasmático de marcação das células de Purkinje. Enquanto observamos padrões aglomerados de marcação na camada de células granulares para anti-SYN e antiSYP, para o anti-NFs observamos marcação ao longo de processos axonais e dendríticos tanto na camada granular quanto molecular (Fig.2-11). Esta análise qualitativa do cerebelo foi realizada apenas no plano entre 10 e $12 \mathrm{~mm}$ posterior ao bregma (Paxinos e Watson, 2005) onde foi possível observar discreto aumento da imunorreatividade para SYN (Fig.2-12) e NFs (Fig.2-13).

A análise por Western blotting do cerebelo revelou aumentos estatisticamente significativos em EX7 e EX15 dos níveis de SYN $(p<0,05)$ (Fig.2-12) e em EX3 dos níveis de NF68 $(p<0,05)$ (Fig.2-13), como descrito na Tabela 3. Não foi observada mudança na expressão dos RNAm avaliados no cerebelo.

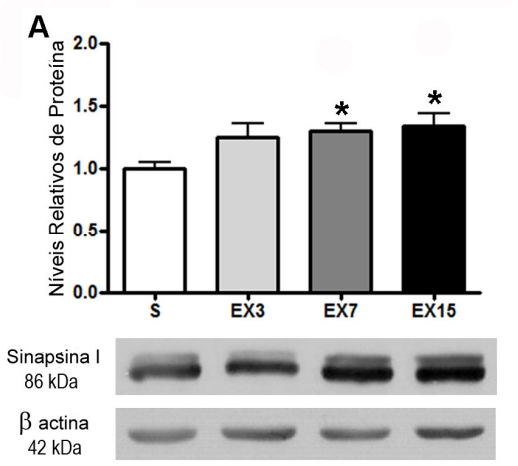

B

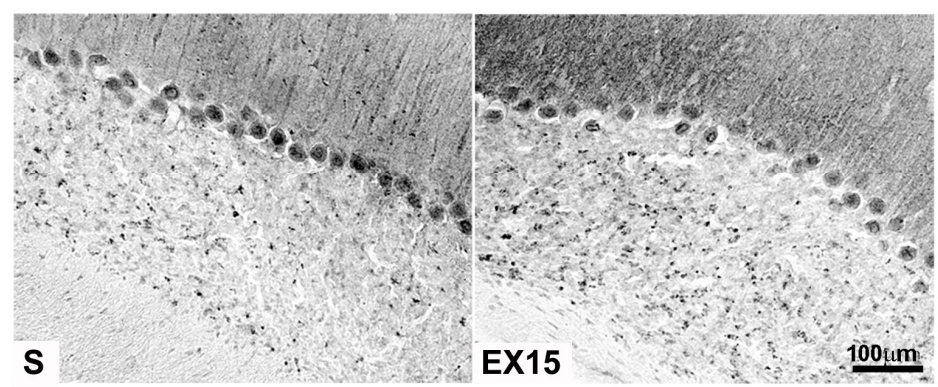

Figura 2-12. Efeitos do exercício sobre a proteína sinapsina I no cerebelo. (A) O gráfico representa a média da razão entre a densidade óptica das bandas das proteínas de interesse e da $\beta$-actina. Os dados estão normalizados pelo grupo sedentário e as bandas ilustradas são exemplos típicos de cada immunoblot. (B) Imagens digitais de cortes coronais de encéfalo de rato ilustrando discreto aumento da imunorreatividade para SYN. S: sedentário; EX3: 3 dias de exercício; EX7: 7 dias de exercício; EX15: 15 dias de exercício ( ${ }^{*} p<0.05$ vs. grupo sedentário). 

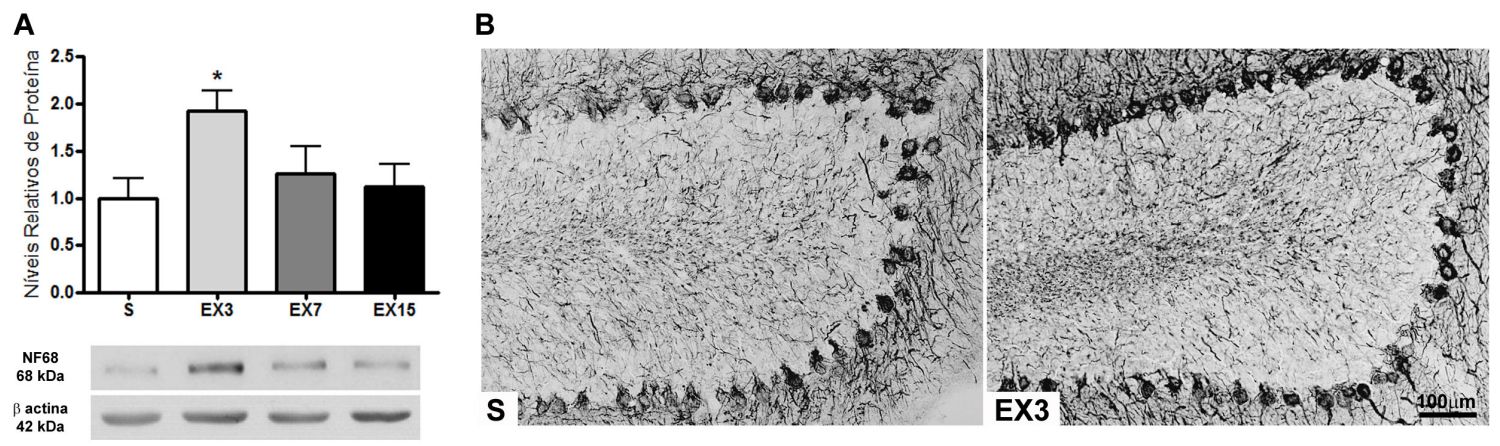

Figura 2-13. Efeitos do exercício sobre a proteína neurofilamento $68 \mathrm{kDa}$ no cerebelo. (A) O gráfico representa a média da razão entre a densidade óptica das bandas das proteínas de interesse e da $\beta$-actina. Os dados estão normalizados pelo grupo sedentário e as bandas ilustradas são exemplos típicos de cada immunoblot. (B) Imagens digitais de cortes coronais de encéfalo de rato ilustrando discreto aumento da imunorreatividade para NFs. S: sedentário; EX3: 3 dias de exercício; EX7: 7 dias de exercício; EX15: 15 dias de exercício ( ${ }^{*} p<0.05$ vs. grupo sedentário).

\subsubsection{Substância Negra}

Foi observada na substância negra uma exceção para o padrão de marcação para anti-SYN, que apresentou uma marcação muito fraca e difícil de identificar (Fig.2-11). Já para a SYP prevaleceu um padrão de marcação citoplasmático, enquanto que padrão para os NFs formou uma densa malha de processos (Fig.211). Este padrão de marcação foi observado de forma geral em ambas as principais subdivisões da substância negra (pars compacta e pars reticulata) e foi possível observar aumento da imunorreatividade para NFs (Fig.2-14).

Foi observado aumento do RNAm para SYN em EX3 $(p<0,05)$ e em EX7 $(p<0,01)$, enquanto que o RNAm para SYP estava aumentado apenas em EX3 $(p<0,001)$. Os níveis destas proteínas, contudo, permaneceram inalterados. Já as proteínas NF68 e NF160 sofreram aumento em EX3 ( $p<0,01)$ (Fig.2-14), enquanto que apenas o RNAm para NF68 aumentou neste mesmo período $(p<0,05)($ Tabela 3). 

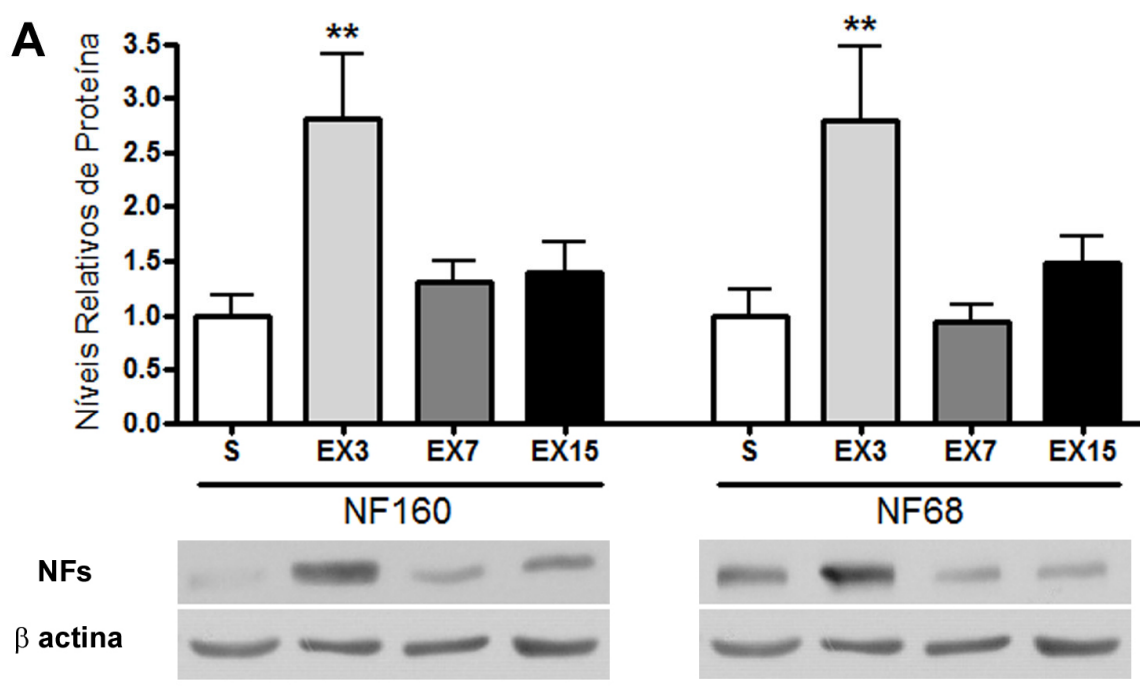

B
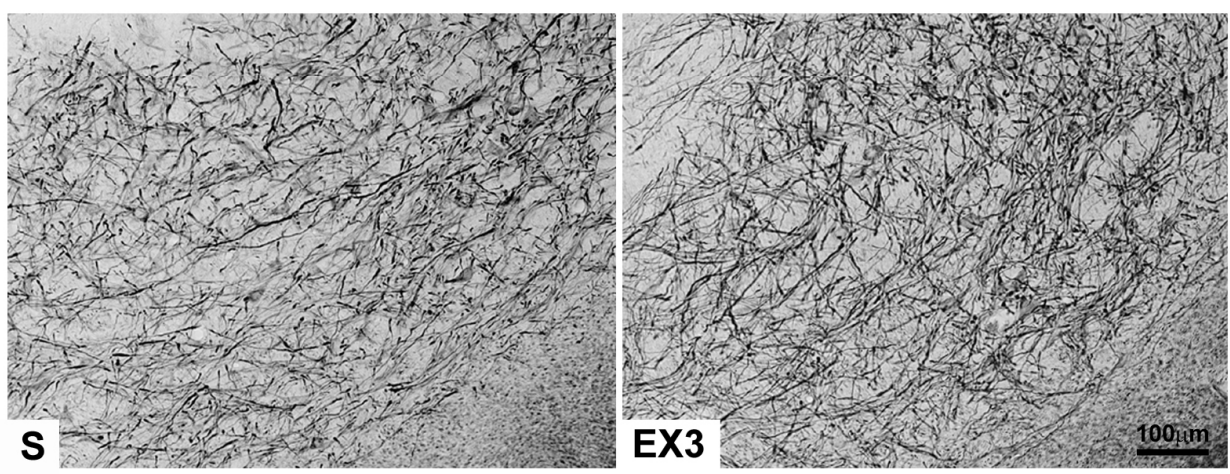

Figura 2-14. Efeitos do exercício sobre a proteínas neurofilamento $68 \mathrm{kDa}$ e $160 \mathrm{kDa}$ na substância negra. (A) Os gráficos representam a média da razão entre a densidade óptica das bandas das proteínas de interesse e da $\beta$-actina. Os dados estão normalizados pelos respectivos grupos sedentários e as bandas ilustradas são exemplos típicos de cada immunoblot. (B) Imagens digitais de cortes coronais de encéfalo de rato ilustrando aumento da imunorreatividade para NFs. S: sedentário; EX3: 3 dias de exercício; EX7: 7 dias de exercício; EX15: 15 dias de exercício ( ${ }^{* \star} p<0.01$ vs. grupo sedentário).

\subsubsection{Estriado}

No estriado rostral (entre 1 e $2 \mathrm{~mm}$ rostral ao bregma), o padrão de marcação observado para SYN e SYP foi bastante difuso e apenas anti-SYN marcou corpos celulares. Nesta região o padrão de marcação observado para NFs foi pontilhado coincidindo com as regiões de passagem de feixes (Fig.2-11). Foi possível observar aumento da imunorreatividade para SYN (Fig.2-15), SYP (Fig.2-16) e NFs (Fig.2-17) nestas regiões. 
Pode-se observar aumentos significativos da expressão do RNAm para SYN em EX3 $(p<0,05)$, enquanto que os níveis protéicos encontravam-se aumentados em EX3 e EX7 ( $p<0,05)$ (Fig.2-15). Já para a SYP, os níveis protéicos aumentaram em EX7 ( $p<0,05)$, mas o RNAm diminuiu sua expressão em EX15 $(p<0,05)$ (Tabela 3) (Fig.2-16).

Para os NFs, observamos um aumento dos níveis protéicos de NF68 em EX3 $(p<0,01)$ (Fig.2-17) seguido da redução da expressão do RNAm para NF200 em EX15 $(p<0,05)$ e para NF68 em EX7 $(p<0,05)$ e EX15 $(p<0,01)($ Tabela 3$)$.
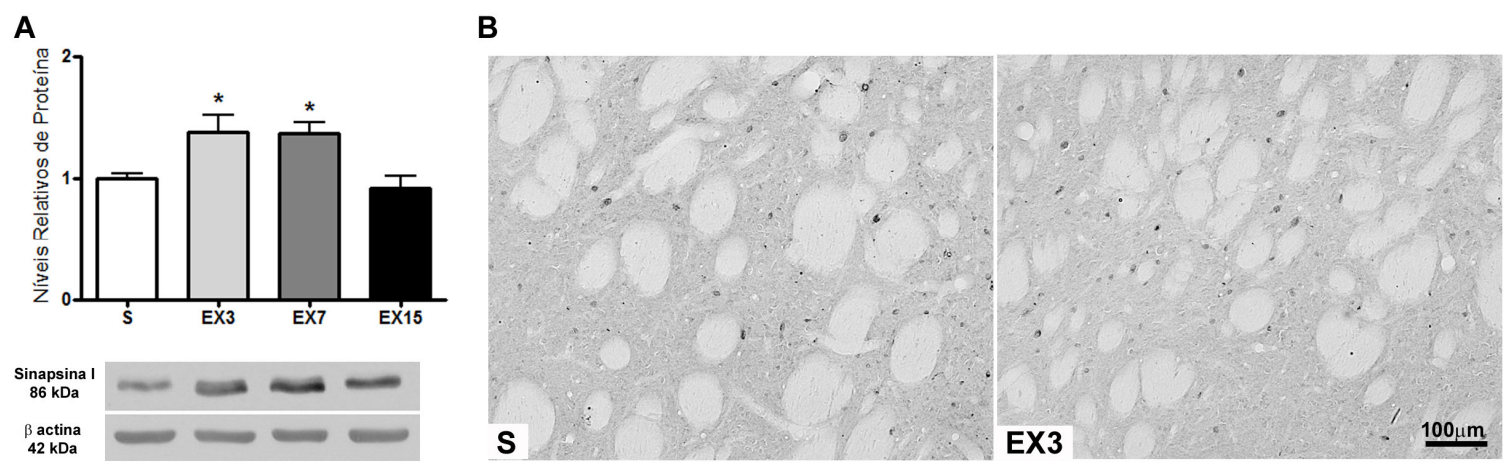

Figura 2-15. Efeitos do exercício sobre a proteína sinapsina I no estriado. (A) O gráfico representa a média da razão entre a densidade óptica das bandas das proteínas de interesse e da $\beta$-actina. Os dados estão normalizados pelo grupo sedentário e as bandas ilustradas são exemplos típicos de cada immunoblot. (B) Imagens digitais de cortes coronais de encéfalo de rato ilustrando discreto aumento da imunorreatividade para SYN. S: sedentário; EX3: 3 dias de exercício; EX7: 7 dias de exercício; EX15: 15 dias de exercício ( ${ }^{*} p<0.05$ vs. grupo sedentário).
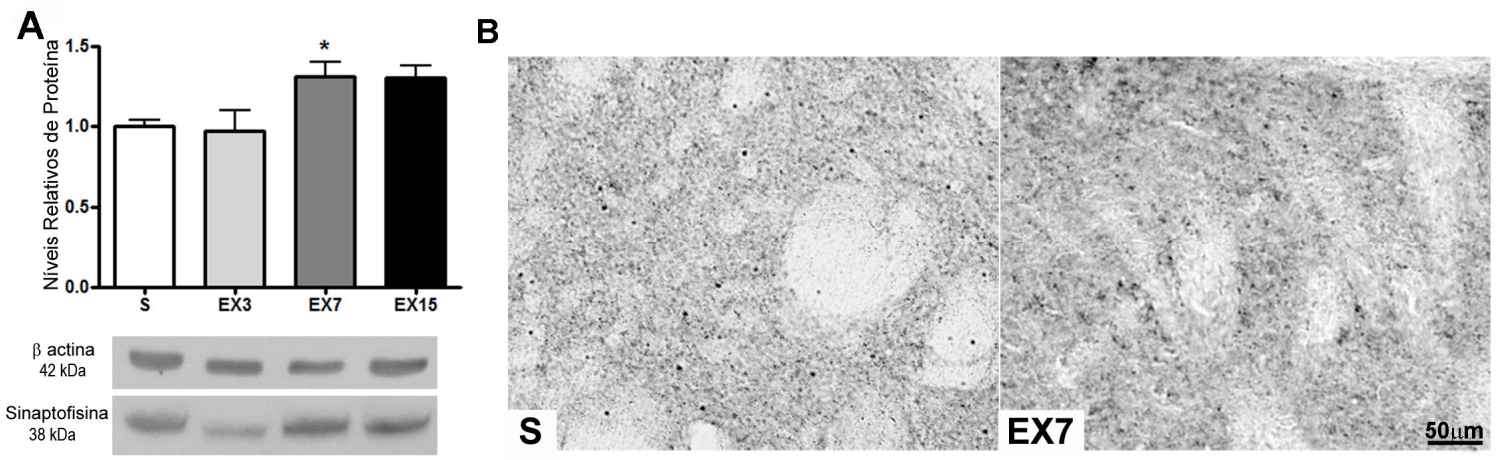

Figura 2-16. Efeitos do exercício sobre a proteína sinaptofisina no estriado. (A) O gráfico representa a média da razão entre a densidade óptica das bandas das proteínas de interesse e da $\beta$-actina. Os dados estão normalizados pelo grupo sedentário e as bandas ilustradas são exemplos típicos de cada immunoblot. (B) Imagens digitais de cortes coronais de encéfalo de rato ilustrando aumento da imunorreatividade para SYP. S: sedentário; EX3: 3 dias de exercício; EX7: 7 dias de exercício; EX15: 15 dias de exercício ( ${ }^{*} p<0.05$ vs. grupo sedentário). 
A

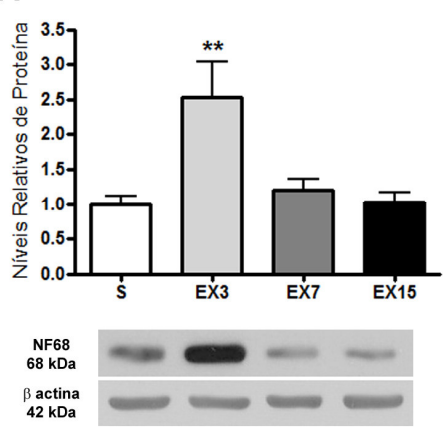

B

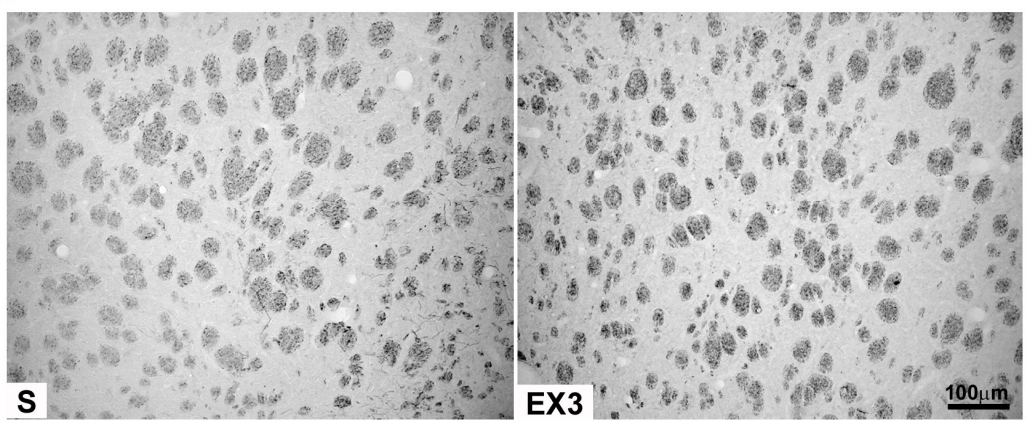

Figura 2-17. Efeitos do exercício sobre a proteína neurofilamento 68kDa no estriado. (A) O gráfico representa a média da razão entre a densidade óptica das bandas das proteínas de interesse e da $\beta$-actina. Os dados estão normalizados pelo grupo sedentário e as bandas ilustradas são exemplos típicos de cada immunoblot. (B) Imagens digitais de cortes coronais de encéfalo de rato ilustrando discreto aumento da imunorreatividade para NFs. S: sedentário; EX3: 3 dias de exercício; EX7: 7 dias de exercício; EX15: 15 dias de exercício ( ${ }^{*} p<0.01$ vs. grupo sedentário).

\subsubsection{Córtex Motor}

No córtex motor, a marcação para SYN e SYP também se apresentou de forma difusa com uma marcação citoplasmática densa, enquanto o padrão de marcação para os NFs foi similar ao padrão encontrado no cerebelo, marcando processos e corpos celulares (Fig.2-11). Esta análise foi centrada em uma região intermediária do córtex motor primário, entre 1 e $2 \mathrm{~mm}$ rostral ao bregma, onde foi possível observar aumento da imunorreatividade para NFs em EX15 (Fig.2-18).

Apenas os níveis protéicos dos NFs sofreram alteração neste protocolo. Houve uma redução dos níveis de NF160 e NF68 em EX3 $(p<0,05)$ seguido de um aumento dos níveis de NF68 em EX15 (p<0,05) (Fig.2-18) (Tabela 3). 

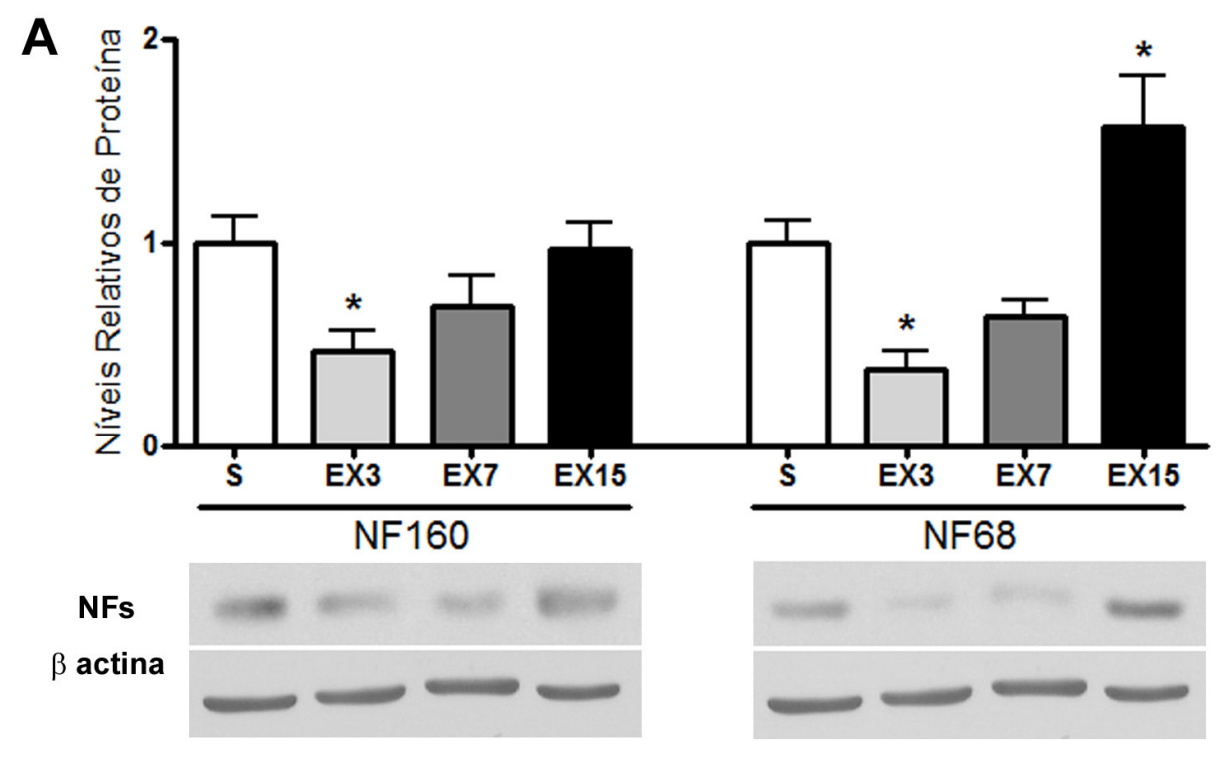

B

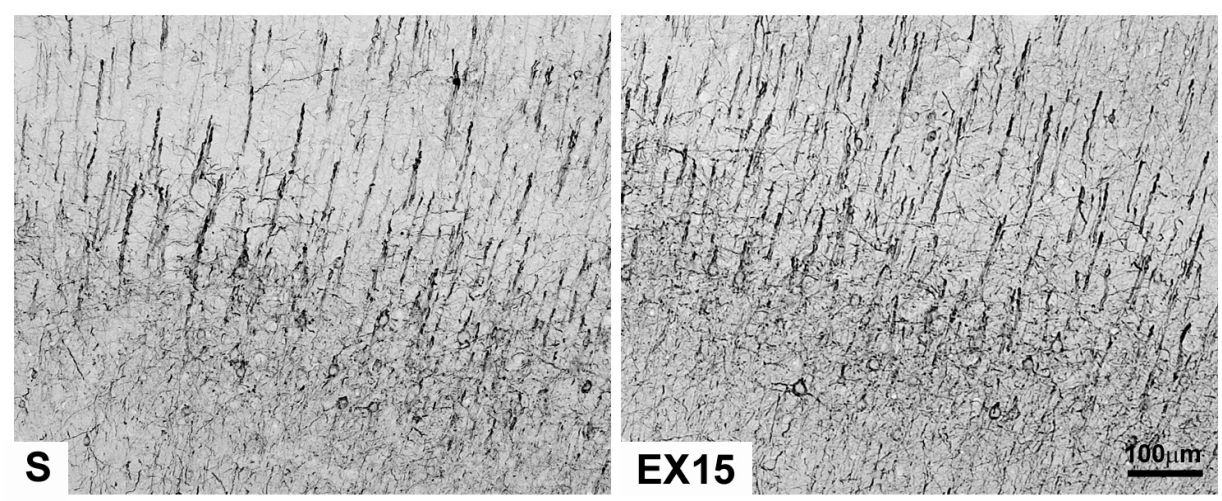

Figura 2-18. Efeitos do exercício sobre a proteínas neurofilamento $68 \mathrm{kDa}$ e $160 \mathrm{kDa}$ no córtex motor. (A) Os gráficos representam a média da razão entre a densidade óptica das bandas das proteínas de interesse e da $\beta$-actina. Os dados estão normalizados pelos respectivos grupos sedentários e as bandas ilustradas são exemplos típicos de cada immunoblot. (B) Imagens digitais de cortes coronais de encéfalo de rato ilustrando aumento da imunorreatividade para NFs. S: sedentário; EX3: 3 dias de exercício; EX7: 7 dias de exercício; EX15: 15 dias de exercício ( $p<0.05 ;{ }^{* \star} p<0.01 ;{ }^{* \star \star} p<0.001$ vs. grupo sedentário).

\subsubsection{Tronco Encefálico}

O padrão de marcação observado para SYN e SYP na formação reticular do tronco encefálico (mais especificamente, o núcleo gigantocelular e regiões adjacentes entre 10 e 12 posterior ao bregma) foi similar ao que foi observado no córtex motor, enquanto que a marcação para NFs foi observada em neurópila e 
pericária (Fig. 2-11). Nesta região também foi possível observar aumento da imunorreatividade para NFs em EX15 (Fig.2-19).

Apesar de não terem sido observadas mudanças nos níveis de SYN e SYP nem nos seus RNAm, foi observado aumento dos níveis dos três NFs em EX15 $(p<0,05)$ (Fig.2-19), aumento da expressão do RNAm para NF160 em todos os tempos de exercício ( $p<0,05$ em EX3, $p<0,001$ em EX7 e $p<0,01$ em EX15) e do RNAm para NF68 em EX7 ( $p<0,05)$ (Tabela 3).
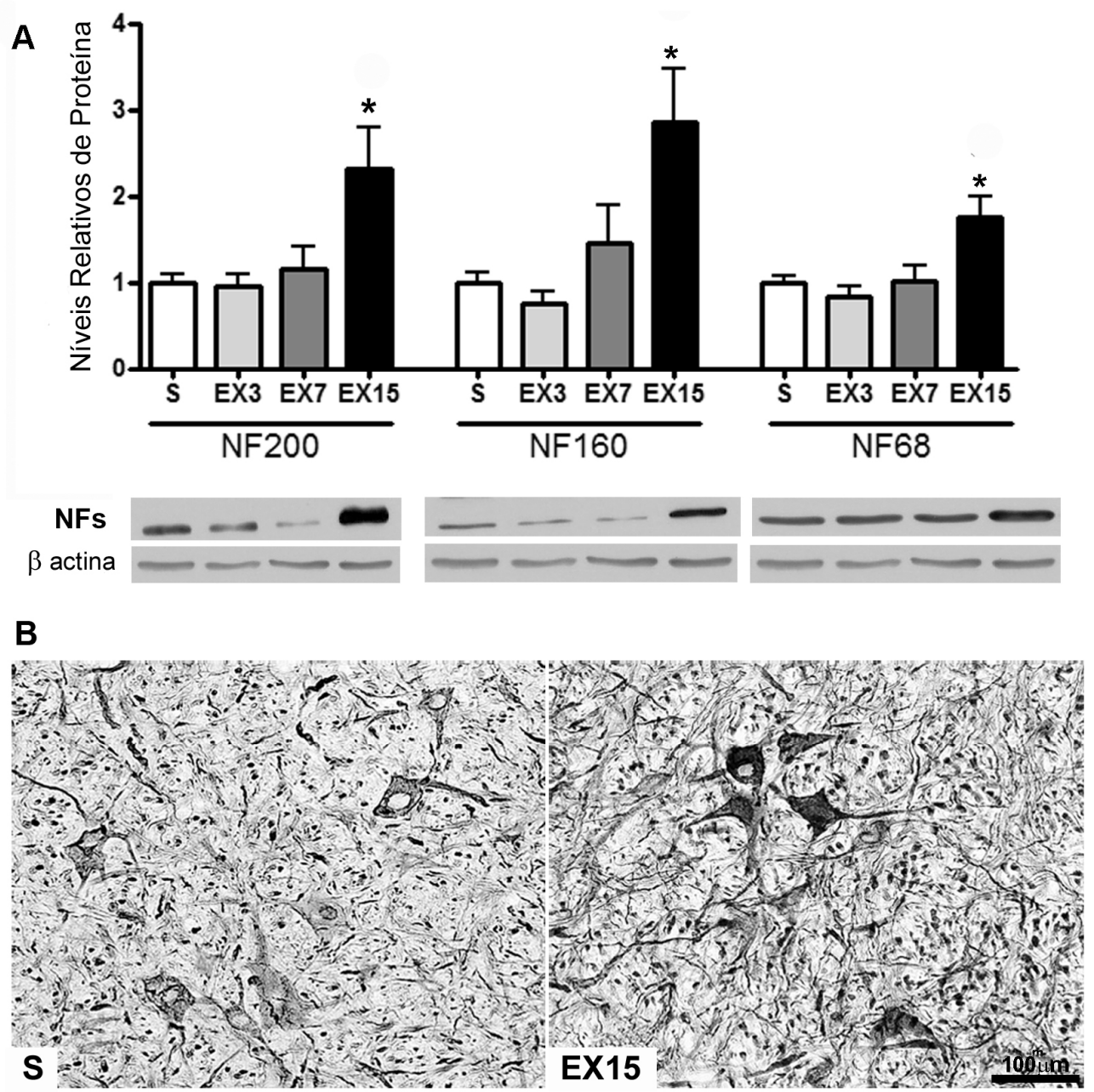

Figura 2-19. Efeitos do exercício sobre as proteínas neurofilamento 200kDa, 160kDa e 68kDa na formação reticular do tronco encefálico. (A) Os gráficos representam a média da razão entre a densidade óptica das bandas das proteínas de interesse e da $\beta$-actina. Os dados estão normalizados pelos respectivos grupos sedentários e as bandas ilustradas são exemplos típicos de cada immunoblot. (B) Imagens digitais de cortes coronais de encéfalo de rato ilustrando aumento da imunorreatividade para NFs. S: sedentário; EX3: 3 dias de exercício; EX7: 7 dias de exercício; EX15: 15 dias de exercício ( ${ }^{*} p<0,05$ vs. grupo sedentário). 
Tabela 3 - Níveis protéicos e de RNAm dos elementos sinápticos e estruturais nas regiões motoras após diferentes tempos de exercício moderado.

\begin{tabular}{|c|c|c|c|c|c|c|c|c|c|}
\hline \multirow{3}{*}{ 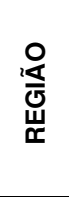 } & \multirow{3}{*}{ PROTEÍNA } & \multicolumn{4}{|c|}{ WESTERN BLOTTING } & \multicolumn{4}{|c|}{ PCR em tempo real } \\
\hline & & $\mathbf{S}$ & EX3 & EX7 & EX15 & $\mathbf{S}$ & EX3 & EX7 & EX15 \\
\hline & & $\begin{array}{l}\text { MÉDIA } \\
( \pm \text { SEM) }\end{array}$ & $\begin{array}{l}\text { MÉDIA } \\
\text { ( } \pm \text { SEM) }\end{array}$ & $\begin{array}{l}\text { MÉDIA } \\
( \pm \text { SEM) }\end{array}$ & $\begin{array}{l}\text { MÉDIA } \\
\text { (士SEM) }\end{array}$ & $\begin{array}{l}\text { MÉDIA } \\
( \pm \text { SEM) }\end{array}$ & $\begin{array}{l}\text { MÉDIA } \\
( \pm \text { SEM) }\end{array}$ & $\begin{array}{l}\text { MÉDIA } \\
\text { (士SEM) }\end{array}$ & $\begin{array}{l}\text { MÉDIA } \\
( \pm \text { SEM) }\end{array}$ \\
\hline \multirow{5}{*}{ 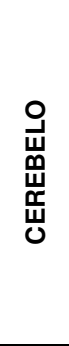 } & SYN & $\begin{array}{c}1 \\
( \pm 0,05)\end{array}$ & $\begin{array}{c}1,25 \\
( \pm 0,11)\end{array}$ & $\begin{array}{c}1,30 \\
( \pm 0,06)\end{array}$ * & $\begin{array}{c}1,34 \\
( \pm 0,10)\end{array}$ * & $\begin{array}{c}1 \\
( \pm 0,21)\end{array}$ & $\begin{array}{c}2,44 \\
( \pm 0,55)\end{array}$ & $\begin{array}{c}1,70 \\
( \pm 0,46)\end{array}$ & $\begin{array}{c}2,24 \\
( \pm 0,54)\end{array}$ \\
\hline & SYP & $\begin{array}{c}1 \\
( \pm 0,15)\end{array}$ & $\begin{array}{c}1,29 \\
( \pm 0,30)\end{array}$ & $\begin{array}{c}1,15 \\
( \pm 0,13)\end{array}$ & $\begin{array}{c}1,17 \\
( \pm 0,17)\end{array}$ & $\begin{array}{c}1 \\
( \pm 0,61)\end{array}$ & $\begin{array}{c}11,38 \\
( \pm 9,96)\end{array}$ & $\begin{array}{c}3,47 \\
( \pm 1,60)\end{array}$ & $\begin{array}{c}12,30 \\
( \pm 7,03)\end{array}$ \\
\hline & NF68 & $\begin{array}{c}1 \\
( \pm 0,21)\end{array}$ & $\begin{array}{c}1,92 \\
( \pm 0,21)\end{array}$ * & $\begin{array}{c}1,26 \\
( \pm 0,28)\end{array}$ & $\begin{array}{c}1,12 \\
( \pm 0,25)\end{array}$ & $\begin{array}{c}1 \\
( \pm 0,07)\end{array}$ & $\begin{array}{c}1,47 \\
( \pm 0,27)\end{array}$ & $\begin{array}{c}1,16 \\
( \pm 0,08)\end{array}$ & $\begin{array}{c}1,22 \\
( \pm 0,07)\end{array}$ \\
\hline & NF160 & $\begin{array}{c}1 \\
( \pm 0,18)\end{array}$ & $\begin{array}{c}1,68 \\
( \pm 0,34)\end{array}$ & $\begin{array}{c}1,31 \\
( \pm 0,32)\end{array}$ & $\begin{array}{c}1,01 \\
( \pm 0,12)\end{array}$ & $\begin{array}{c}1 \\
( \pm 0,12)\end{array}$ & $\begin{array}{c}0,97 \\
( \pm 0,06)\end{array}$ & $\begin{array}{c}0,98 \\
( \pm 0,06)\end{array}$ & $\begin{array}{c}1,18 \\
( \pm 0,13)\end{array}$ \\
\hline & NF200 & nd & nd & nd & nd & $\begin{array}{c}1 \\
( \pm 0,09)\end{array}$ & $\begin{array}{c}1,13 \\
( \pm 0,10)\end{array}$ & $\begin{array}{c}1,00 \\
( \pm 0,18)\end{array}$ & $\begin{array}{c}0,95 \\
( \pm 0,12)\end{array}$ \\
\hline \multirow{5}{*}{ 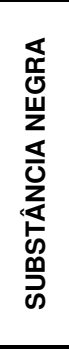 } & SYN & $\begin{array}{c}1 \\
( \pm 0,19)\end{array}$ & $\begin{array}{c}1,18 \\
( \pm 0,27)\end{array}$ & $\begin{array}{c}1,49 \\
( \pm 0,43)\end{array}$ & $\begin{array}{c}0,95 \\
( \pm 0,15)\end{array}$ & $\begin{array}{c}1 \\
( \pm 0,62)\end{array}$ & $\begin{array}{c}2,92 \\
( \pm 0,36)\end{array}$ * & $\begin{array}{c}3,18 \\
( \pm 0,42)\end{array}$ ** & $\begin{array}{c}2,21 \\
( \pm 0,30)\end{array}$ \\
\hline & SYP & $\begin{array}{c}1 \\
( \pm 0,12)\end{array}$ & $\begin{array}{c}1,06 \\
( \pm 0,17)\end{array}$ & $\begin{array}{c}1,66 \\
( \pm 0,35)\end{array}$ & $\begin{array}{c}1,10 \\
( \pm 0,13)\end{array}$ & $\begin{array}{c}1 \\
( \pm 0,44)\end{array}$ & $\begin{array}{c}4,26 \\
( \pm 1,07)^{\star \star \star}\end{array}$ & $\begin{array}{c}0,51 \\
( \pm 0,05)\end{array}$ & $\begin{array}{c}0,68 \\
( \pm 0,16)\end{array}$ \\
\hline & NF68 & $\begin{array}{c}1 \\
( \pm 0,23)\end{array}$ & $\begin{array}{c}2,80 \\
( \pm 0,68) \text { ** }\end{array}$ & $\begin{array}{c}0,95 \\
( \pm 0,15)\end{array}$ & $\begin{array}{c}1,47 \\
( \pm 0,26)\end{array}$ & $\begin{array}{c}1 \\
( \pm 0,10)\end{array}$ & $\begin{array}{c}2,32 \\
( \pm 0,36)\end{array}$ * & $\begin{array}{c}1,71 \\
( \pm 0,24)\end{array}$ & $\begin{array}{c}1,39 \\
( \pm 0,33)\end{array}$ \\
\hline & NF160 & $\begin{array}{c}1 \\
( \pm 0,19)\end{array}$ & $\begin{array}{c}2,82 \\
( \pm 0,59)\end{array}$ ** & $\begin{array}{c}1,31 \\
( \pm 0,20)\end{array}$ & $\begin{array}{c}1,40 \\
( \pm 0,27)\end{array}$ & $\begin{array}{c}1 \\
( \pm 0,17)\end{array}$ & $\begin{array}{c}1,48 \\
( \pm 0,19)\end{array}$ & $\begin{array}{c}1,12 \\
( \pm 0,10)\end{array}$ & $\begin{array}{c}1,13 \\
( \pm 0,18)\end{array}$ \\
\hline & NF200 & nd & nd & nd & nd & $\begin{array}{c}1 \\
( \pm 0,16)\end{array}$ & $\begin{array}{c}1,69 \\
( \pm 0,24)\end{array}$ & $\begin{array}{c}1,52 \\
( \pm 0,24)\end{array}$ & $\begin{array}{c}1,77 \\
( \pm 0,11)\end{array}$ \\
\hline \multirow{5}{*}{ 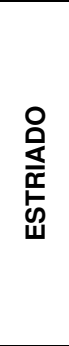 } & SYN & $\begin{array}{c}1 \\
( \pm 0,04)\end{array}$ & $\begin{array}{c}1,37 \\
( \pm 0,14)\end{array}$ * & $\begin{array}{c}1,37 \\
( \pm 0,09) \text { * }\end{array}$ & $\begin{array}{c}0,92 \\
( \pm 0,10)\end{array}$ & $\begin{array}{c}1 \\
( \pm 0,14)\end{array}$ & $\begin{array}{c}1,49 \\
( \pm 0,13)\end{array}$ * & $\begin{array}{c}1,31 \\
( \pm 0,09)\end{array}$ & $\begin{array}{c}0,82 \\
( \pm 0,12)\end{array}$ \\
\hline & SYP & $\begin{array}{c}1 \\
( \pm 0,04)\end{array}$ & $\begin{array}{c}0,97 \\
( \pm 0,13)\end{array}$ & $\begin{array}{c}1,31 \\
( \pm 0,09) \text { * }\end{array}$ & $\begin{array}{c}1,30 \\
( \pm 0,08)\end{array}$ & $\begin{array}{c}1 \\
( \pm 0,17)\end{array}$ & $\begin{array}{c}1,26 \\
( \pm 0,11)\end{array}$ & $\begin{array}{c}1,24 \\
( \pm 0,16)\end{array}$ & $\begin{array}{c}0,44 \\
( \pm 0,11) \text { * }\end{array}$ \\
\hline & NF68 & $\begin{array}{c}1 \\
( \pm 0,12)\end{array}$ & $\begin{array}{c}2,53 \\
( \pm 0,51)\end{array}$ ** & $\begin{array}{c}1,19 \\
( \pm 0,16)\end{array}$ & $\begin{array}{c}1,03 \\
( \pm 0,13)\end{array}$ & $\begin{array}{c}1 \\
( \pm 0,15)\end{array}$ & $\begin{array}{c}0,82 \\
( \pm 0,07)\end{array}$ & $\begin{array}{c}0,62 \\
( \pm 0,07) \text { * }\end{array}$ & $\begin{array}{c}0,44 \\
( \pm 0,06)\end{array}$ ** \\
\hline & NF160 & nd & nd & nd & nd & $\begin{array}{c}1 \\
( \pm 0,08)\end{array}$ & $\begin{array}{c}1,07 \\
( \pm 0,12)\end{array}$ & $\begin{array}{c}1,08 \\
( \pm 0,12)\end{array}$ & $\begin{array}{c}1,11 \\
( \pm 0,09)\end{array}$ \\
\hline & NF200 & nd & nd & nd & nd & $\begin{array}{c}1 \\
( \pm 0,15) \\
\end{array}$ & $\begin{array}{r}1,15 \\
( \pm 0,10) \\
\end{array}$ & $\begin{array}{c}0,96 \\
( \pm 0,05) \\
\end{array}$ & $\begin{array}{c}0,50 \\
( \pm 0,07) \text { * } \\
\end{array}$ \\
\hline \multirow{5}{*}{ 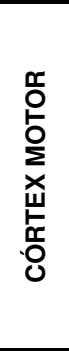 } & SYN & $\begin{array}{c}1 \\
( \pm 0,19)\end{array}$ & $\begin{array}{c}1,02 \\
( \pm 0,10)\end{array}$ & $\begin{array}{c}1,03 \\
( \pm 0,09)\end{array}$ & $\begin{array}{c}0,94 \\
( \pm 0,18)\end{array}$ & $\begin{array}{c}1 \\
( \pm 0,05)\end{array}$ & $\begin{array}{c}0,60 \\
( \pm 0,13)\end{array}$ & $\begin{array}{c}0,93 \\
( \pm 0,14)\end{array}$ & $\begin{array}{c}0,99 \\
( \pm 0,16)\end{array}$ \\
\hline & SYP & $\begin{array}{c}1 \\
( \pm 0,13)\end{array}$ & $\begin{array}{c}0,97 \\
( \pm 0,16)\end{array}$ & $\begin{array}{c}0,95 \\
( \pm 0,05)\end{array}$ & $\begin{array}{c}1,07 \\
( \pm 0,23)\end{array}$ & $\begin{array}{c}1 \\
( \pm 0,07)\end{array}$ & $\begin{array}{c}0,97 \\
( \pm 0,21)\end{array}$ & $\begin{array}{c}0,75 \\
( \pm 0,11)\end{array}$ & $\begin{array}{c}0,86 \\
( \pm 0,11)\end{array}$ \\
\hline & NF68 & $\begin{array}{c}1 \\
( \pm 0,11)\end{array}$ & $\begin{array}{c}0,37 \\
( \pm 0,10)\end{array}$ * & $\begin{array}{c}0,64 \\
( \pm 0,08)\end{array}$ & $\begin{array}{c}1,57 \\
( \pm 0,25) \text { * }\end{array}$ & $\begin{array}{c}1 \\
( \pm 0,12)\end{array}$ & $\begin{array}{c}1,02 \\
( \pm 0,23)\end{array}$ & $\begin{array}{c}1,16 \\
( \pm 0,14)\end{array}$ & $\begin{array}{c}1,48 \\
( \pm 0,17)\end{array}$ \\
\hline & NF160 & $\begin{array}{c}1 \\
( \pm 0,13)\end{array}$ & $\begin{array}{c}0,47 \\
( \pm 0,10)\end{array}$ * & $\begin{array}{c}0,69 \\
( \pm 0,15)\end{array}$ & $\begin{array}{c}0,97 \\
( \pm 0,13)\end{array}$ & $\begin{array}{c}1 \\
( \pm 0,11)\end{array}$ & $\begin{array}{c}1,10 \\
( \pm 0,15)\end{array}$ & $\begin{array}{c}1,28 \\
( \pm 0,14)\end{array}$ & $\begin{array}{c}1,55 \\
( \pm 0,22)\end{array}$ \\
\hline & NF200 & nd & nd & nd & nd & $\begin{array}{c}1 \\
( \pm 0,04)\end{array}$ & $\begin{array}{c}0,79 \\
( \pm 0,13)\end{array}$ & $\begin{array}{c}0,92 \\
( \pm 0,13)\end{array}$ & $\begin{array}{c}1,15 \\
( \pm 0,12)\end{array}$ \\
\hline \multirow{5}{*}{ 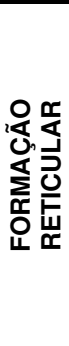 } & SYN & $\begin{array}{c}1 \\
( \pm 0,15)\end{array}$ & $\begin{array}{c}1,06 \\
( \pm 0,09)\end{array}$ & $\begin{array}{c}1,20 \\
( \pm 0,06)\end{array}$ & $\begin{array}{c}1,02 \\
( \pm 0,10)\end{array}$ & $\begin{array}{c}1 \\
( \pm 0,10)\end{array}$ & $\begin{array}{c}1,34 \\
( \pm 0,34)\end{array}$ & $\begin{array}{c}1,58 \\
( \pm 0,25)\end{array}$ & $\begin{array}{c}1,38 \\
( \pm 0,32)\end{array}$ \\
\hline & SYP & $\begin{array}{c}1 \\
( \pm 0,10)\end{array}$ & $\begin{array}{c}1,07 \\
( \pm 0,05)\end{array}$ & $\begin{array}{c}1,02 \\
( \pm 0,06)\end{array}$ & $\begin{array}{c}0,99 \\
( \pm 0,08)\end{array}$ & $\begin{array}{c}1 \\
( \pm 0,14)\end{array}$ & $\begin{array}{c}1,63 \\
( \pm 0,66)\end{array}$ & $\begin{array}{c}1,04 \\
( \pm 0,23)\end{array}$ & $\begin{array}{c}1,63 \\
( \pm 0,44)\end{array}$ \\
\hline & NF68 & $\begin{array}{c}1 \\
( \pm 0,07)\end{array}$ & $\begin{array}{c}0,83 \\
( \pm 0,12)\end{array}$ & $\begin{array}{c}1,02 \\
( \pm 0,17)\end{array}$ & $\begin{array}{c}1,76 \\
( \pm 0,23) \text { * }\end{array}$ & $\begin{array}{c}1 \\
( \pm 0,07)\end{array}$ & $\begin{array}{c}1,18 \\
( \pm 0,09)\end{array}$ & $\begin{array}{c}1,38 \\
( \pm 0,06) \text { * }\end{array}$ & $\begin{array}{c}1,07 \\
( \pm 0,10)\end{array}$ \\
\hline & NF160 & $\begin{array}{c}1 \\
( \pm 0,12)\end{array}$ & $\begin{array}{c}0,76 \\
( \pm 0,13)\end{array}$ & $\begin{array}{c}1,45 \\
( \pm 0,45)\end{array}$ & $\begin{array}{c}2,86 \\
( \pm 0,62) \text { * }\end{array}$ & $\begin{array}{c}1 \\
( \pm 0,07)\end{array}$ & $\begin{array}{c}1,41 \\
( \pm 0,06) \text { * }\end{array}$ & $\begin{array}{c}1,56 \\
( \pm 0,04)^{\star \star \star}\end{array}$ & $\begin{array}{c}1,39 \\
( \pm 0,09) \text { ** }\end{array}$ \\
\hline & NF200 & $\begin{array}{c}1 \\
( \pm 0,09)\end{array}$ & $\begin{array}{c}0,95 \\
( \pm 0,15)\end{array}$ & $\begin{array}{c}1,15 \\
( \pm 0,26)\end{array}$ & $\begin{array}{c}2,31 \\
( \pm 0,48) \text { * }\end{array}$ & $\begin{array}{c}1 \\
( \pm 0,07)\end{array}$ & $\begin{array}{c}1,15 \\
( \pm 0,11) \\
\end{array}$ & $\begin{array}{c}1,17 \\
( \pm 0,16) \\
\end{array}$ & $\begin{array}{c}1,01 \\
( \pm 0,08) \\
\end{array}$ \\
\hline
\end{tabular}

S: sedentário; EX3: 3 dias de exercício; EX7: 7 dias de exercício; EX15: 15 dias de exercício; SYN: sinapsina I; SYP: sinaptofisina; NF68: neurofilamento 68kDa; NF160: neurofilamento 160kDa; NF200: neurofilamento 200kDa; nd: não detectado ( ${ }^{*} p<0,05 ;{ }^{* *} p<0,01 ;{ }^{* * *} p<0,001$ vs. grupo sedentário). 


\subsection{DISCUSSÃO}

\subsubsection{Protocolo de Exercício e Corticosterona Plasmática}

A utilização de protocolos de exercícios tem sido intensamente explorada em pesquisas do sistema nervoso central com inúmeros objetivos, sendo os principais a detecção de alterações em áreas ligadas ao controle cardiovascular (Higa-Taniguchi et al., 2007; Jackson et al., 2005) e de alterações em áreas relacionadas à memória, aprendizado e cognição de forma geral (Ding et al., 2006a; Ishide et al., 2005; Kushner et al., 2005). O enfoque em áreas relacionadas ao controle motor, contudo, é mais limitado.

A grande maioria dos estudos que avaliam alterações decorrentes do exercício em regiões cognitivas, como o hipocampo, utiliza protocolos de exercício voluntário, ou seja, é disponibilizada para o animal uma roda, onde o animal escolhe quando se exercitar, em que velocidade e por quanto tempo (Arida et al., 2004b; Vaynman et al., 2006; van Praag et al., 2005). No nosso protocolo, o exercício é caracterizado como forçado, uma vez que o animal é colocado sobre uma esteira e esta é ligada na velocidade programada, independente da vontade do animal (Arida et al., 2004b). O exercício em esteira tem a vantagem de se assemelhar ao que é praticado por muitos indivíduos (Winter et al., 2007) e por ser um componente chave em muitos programas de reabilitação neurológica (Holschneider et al., 2007). Foi demostrado que o exercício voluntário e o exercício forçado podem ativar vias de sinalização distintas (Chen et al., 2007), o que pode explicar diferenças entre alguns relatos da literatura e nossos achados. Preocupamos-nos em minimizar fatores estressantes, excluindo a fase de teste de esforço do protocolo, iniciando os procedimentos por uma fase de adaptação à esteira, onde o animal tem os primeiros contatos com o equipamento, e utilizando uma velocidade de treinamento moderada $(0,6 \mathrm{~km} / \mathrm{h})$ (Ferreira et al., 2010; Real et al., 2010), uma vez que foram observados altos níveis de cortisol em ratos submetidos a treinamento monitorado e com velocidades mais altas (Ploughman et al., 2005). Um protocolo de corrida estressante (1h a $25 \mathrm{~m} / \mathrm{min}$ ) e familiarização insuficiente dos ratos à esteira e ao ambiente onde serão realizados os exercícios podem resultar em ratos altamente estressados como indicado pelo aumento da resposta da amígdala (Timofeeva et al., 
2003; Vissing et al., 1996). Protocolos de exercício de alto volume e alta intensidade que podem elevar os níveis de corticosterona podem ir contra os efeitos benéficos do BDNF, inibindo a neurogênese (Cosi et al., 1993; Gould et al., 1992); contudo, níveis basais de glicocorticóides parecem ser necessários para a manutenção da neurogênese no encéfalo (Sloviter et al., 1993). Nós medimos os níveis plasmáticos de corticosterona de nossos animais e observamos níveis aumentados em EX3 e EX7. As alterações plásticas encontrados para estes dois grupos devem portanto ser analisadas com cuidado. No entanto, aumentos dos níveis plasmáticos de corticosterona são frequentemente relatados e considerados como representativos de estresse fisiológico (Huang et al., 2006).

Nossa escolha por protocolos de exercício mais curtos se deu pelas fortes evidências que, para alguns processos que ocorrem no sistema nervoso, exercícios de curta duração apresentam mais benefícios que os de longa duração. Foi observado que ratos que correram por períodos mais curtos, cerca de 9 dias, e apresentaram aumento da neurogênese hipocampal, apresentaram também um aumento da fosforilação de CREB na zona subgranular do hipocampo. Esta fosforilação parece regular a neurogênese hipocampal (Nakagawa et al., 2002). Por outro lado, glicocorticoides reduzem os níveis de CREB fosforilada (Yu et al., 2004), levando-nos a crer que alguns protocolos de exercício mais prolongados, e considerados mais estressantes, potencialmente reduzem os níveis de neurogênese. Soya et al. (2007) observaram que exercícios de intensidades baixas já foram capazes de induzir ativação neuronal (avaliada por c-fos), sendo que apenas esta intensidade induziu o aumento da expressão de BDNF no hipocampo sem produzir aumentos de ACTH e adrenalina, que ocorrem no exercício intenso (Soya et al., 2007b). A maioria dos modelos experimentais de exercício em animais utiliza programas diários, porém humanos raramente se exercitam com esta frequência, geralmente realizando apenas níveis modestos de atividade física (Folsom et al., 2000).

Por estas e outras evidências, optamos por avaliar um protocolo de exercício forçado, de curta duração, para avaliar o efeito do exercício de intensidade abaixo do limiar de lactato ao longo do tempo. Optamos por utilizar um biotério com ciclo claro/escuro invertido já que roedores são animais noturnos e normalmente exibem atividade física intensa durante o ciclo escuro. Foi observado que animais permitidos a correr durante outros períodos circadianos, que não o seu período ativo, não 
apresentaram aumento da neurogênese decorrente do exercício (Holmes et al., 2004). Em outro estudo foi observado que ratos submetidos a protocolos de exercício durante o ciclo claro desenvolveram dessincronismo interno, semelhante a trabalhadores noturnos (Salgado-Delgado et al., 2008).

\subsubsection{EfEITOS do Exercício no Hipocampo de RATOS}

O protocolo de exercício moderado de curta duração utilizado induziu aumentos dos níveis protéicos de SYN, NF68, MAP2 e GFAP no hipocampo de ratos. O único efeito transcricional detectado foi um aumento do RNAm que codifica MAP2. As demais proteínas e RNAm estudados permaneceram inalterados nesta região, enquanto que o número de células BrdU-positivas e DCX-positivas aumentou.

Correlações entre o BDNF e proteínas do terminal nervoso sugerem que este fator neurotrófico aumenta a sinaptogênese (Ying et al., 2008). O BDNF modula a plasticidade sináptica no encéfalo adulto (Lo, 1995) e tem a capacidade de modificar a função sináptica no hipocampo, modulando a eficácia da liberação de neurotransmissores (Kang e Schuman, 1995). O BDNF também está relacionado com a indução de LTP (Kramar et al., 2004; van Praag et al., 1999a) e com alterações morfológicas de células e dendritos (Eadie et al., 2005; Griesbach et al., 2004; Lou et al., 2008). Apesar dos inúmeros relatos de aumento deste fator neurotrófico em resposta a variados protocolos de exercício (Vaynman et al., 2003, 2004a, b, 2006; Griesbach et al., 2004b; Ding et al., 2006a), nós não observamos mudanças dos níveis protéicos ou da expressão de RNAm após o protocolo de exercício por nós utilizado. Isso sugere que as mudanças observadas nas outras proteínas, algumas das quais são reguladas pelo BDNF, podem ser reguladas por outros fatores tróficos além do BDNF neste protocolo. Alternativamente, é possível que a sinalização do BDNF esteja aumentada pela sensibilização ou regulação positiva do seu receptor, o que não foi avaliado no presente estudo. Também é possível que os aumentos nos níveis de corticosterona observados nos nossos ratos exercitados tenham interferido no efeito benéfico do exercício nos níveis de BDNF (Cosi et al., 1993; Gould et al., 1992), apesar de não ter inibido como um todo a ocorrência de processos plásticos. 
O BDNF está envolvido na síntese (Wang et al., 1995) e fosforilação da SYN (Jovanovic et al., 2000). Apesar dos níveis de BDNF inalterados nos nossos ratos, observamos aumentos dos níveis de SYN em EX7, sugerindo que esta proteína pode ser regulada por outros fatores. A SYN é frequentemente utilizada como uma preditora de botões pré-sinápticos e do número de sinapses (Cabalka et al., 1992; Goto e Hirano, 1990; Heinonen et al., 1995; Masliah et al., 1995, 1994, 1993). O exercício eleva os níveis de SYN, que está envolvida na aglomeração de vesículas no terminal, liberação de neurotransmissores, alongamento axonal e manutenção de contatos sinápticos (Brock e O'Callaghan, 1987; Jovanovic et al., 1996; Wang et al., 1995). Estes estudos, assim como muitos outros, apóiam nossos achados de aumento da SYN induzido pelo exercício. Não observamos, contudo, mudanças na segunda proteína de vesícula que estudamos, a SYP, apesar de haver relatos de que esta proteína se altera na mesma proporção que a SYN após o exercício (Vaynman et al., 2006). As funções da SYP são menos conhecidas, mas esta proteína parece estar envolvida na biogênese de vesículas sinápticas, fusão da vesícula no terminal e endocitose (Daly et al., 2000; Tartaglia et al., 2001).

As proteínas estruturais estudadas também foram afetadas pelo execício. MAP2 é um marcador sensível e precoce de dano neuronal pós lesão traumática do encéfalo (Huh et al., 2003) e ainda não foi associado a alterações plásticas induzidas pelo exercício. Pode-se observar uma redução de MAP2 após a oclusão reversível da artéria cerebral média seguida de um aumento 1 semana após a reperfusão (Popa-Wagner et al., 1999). Já foi observado que a idade avançada reduz a imunorreatividade para MAP2 (Di Stefano et al., 2006; Himeda et al., 2005). Áreas do encéfalo envolvidas na aquisição e consolidação da memória sofrem uma significativa redução da integridade estrutural e da plasticidade dependente de MAP2 com o envelhecimento (Di Stefano et al., 2001). Acredita-se, portanto, que essas regiões onde ocorre maior plasticidade são mais vulneráveis ao envelhecimento (Di Stefano et al., 2006). Também foi observada redução drástica de MAP2 no giro denteado do hipocampo humano na doença de Alzheimer (Li et al., 2008), em um modelo animal de lesão encefálica (Huh et al., 2003) e no corno de Amon e no giro denteado na presença de cortisol elevado, situação sob a qual também se observa redução de NFs (Cereseto et al., 2006). Apesar de os NFs não serem alvo frequente de estudos experimentais, Reinés et al. (2008) demonstraram que ocorre uma redução do NF68 no modelo de depressão por desamparo 
aprendido. Esta redução parece ser duradoura, uma vez que os níveis de NF68 não voltaram aos níveis basais após tratamento (Reinés et al., 2008).

Por outro lado, aumentos da expressão do RNAm para MAP2 nos dendritos de células granulares tem sido associados à indução de LTP na via perfurante / sinapses de células granulares do hipocampo de ratos (Roberts et al., 1998) e a algumas formas de memória mediadas pelo hipocampo (Fanara et al., 2010).

Nossos resultados revelaram aumentos dos níveis das proteínas MAP2 e NF68, enquanto que apenas o RNAm para MAP2 teve sua expressão aumentada. Aumentos do comprimento de dendritos já foram observados (Stranahan et al., 2007), porém, até o momento, nossos dados são as primeiras evidências de alterações nos níveis protéicos de NFs e MAP2 em resposta ao exercício. Estes dados, assim como os que se encontram na literatura, podem ser interpretados como um efeito plástico benéfico do exercício. Inclusive, acredita-se que aumentos nos níveis protéicos de NFs no corpo cellular são respostas neuroprotetoras no caso de doeças como a esclerose lateral amiotrófica, já que os NFs estão associados a proteínas ligantes de cálcio (revisado por Julien, 1999).

Foi interessante observar nos nossos resultados que o aumento dos níveis protéicos de MAP2 precederam o aumento do RNAm para MAP2. Mudanças dos níveis protéicos na ausência de mudanças da expressão do RNAm podem ser explicadas pelo acúmulo de proteínas devido ao aumento da estabilidade protéica e/ou pela redução da degradação destas (Alberts et al., 2002), o que também se aplica aos nossos dados para SYN e GFAP. Por outro lado, aumento da expressão de RNAm na ausência de níveis protéicos aumentados pode ser explicado, por exemplo, pela influência de microRNAs nos RNAms, inibindo a síntese protéica (Dahm et al., 2007; Gebauer e Hentze, 2004).

Mudanças nos astrócitos induzidas pelo exercício também já foram reportadas anteriormente. Foi observado que a densidade astrocítica, assim como os níveis da proteína GFAP, encontravam-se aumentados após 3 e 6 semanas de exercício em esteira ( $\mathrm{Li}$ et al., 2005). Na SGZ, ocorre um aumento de células que expressam GFAP após 7 dias de exercício em roda de correr (Komitova et al., 2005). Acredita-se que a associação da astrocitose e da angiogênese induzidas pelo exercício fortalece a unidade neurovascular e consequentemente a barreira hematoencefálica, que desempenha funções protetoras, especialmente após lesões encefálicas ( $\mathrm{Li}$ et al., 2005). Considerando os dois estudos mencionados acima, 
nosso trabalho parece ser um dos poucos a observar plasticidade astrocítica após o exercício, uma vez que demostramos aumento dos níveis de GFAP após 15 dias de exercício.

Nós também detectamos um aumento importante da neurogênese adulta induzida pelo exercício. Tem sido mostrado que o exercício voluntário aumenta a neurogênese e melhora o desempenho cognitivo (van Praag, 2008). Nós demostramos aqui que 3 dias de exercício moderado em esteira foram suficientes para induzir um aumento do número de células BrdU-positivas e DCX-positivas no DG de animais exercitados. Uma vez que injetamos BrdU uma única vez nestes animais, este resultado reflete o aumento de proliferação celular em EX3, mas não podemos fazer qualquer inferência sobre a migração e sobrevivência destas células. Outros autores têm relatado aumento de neurogênese após 3 dias de exercício, porém estes utilizaram protocolo de exercício voluntário e não comentaram a distância percorrida pelos camundongos por noite (Kronenberg et al., 2006), portanto limitando possíveis comparações com os nossos resultados. Enquanto que o número de células positivas para BrdU atingiram um pico em EX7 ainda se mantendo acima dos níveis do grupo sedentário após 15 dias de exercício, o aumento do número de células marcadas para DCX foi progressivo. A DCX, ou doublecortin, é uma proteína que promove a polimerização do microtúbulo e que está presente em neuroblastos em migração e em neurônios jovens (von Bohlen Und Halbach, 2007). Nossos achados, portanto, sugerem que o exercício induziu aumento da proliferação celular e induziu aumento dos níveis de neurogênese, aumentando possivelmente a proporção do fenótipo neuronal.

Apesar dos aumentos de corticosterona plasmática encontrados nos nossos grupos EX3 e EX7, ainda assim pudemos observar aumentos dos níveis de NF68 e MAP2 em EX3, acompanhados do aumento da proliferação celular na SGZ. Acreditamos que os aumentos dos níveis de corticosterona observados foram fisiológicos (Huang et al., 2006) e tiveram apenas impacto limitado na plasticidade hipocampal, apesar do estresse ser um dos mais potentes inibidores da neurogênese adulta (Cosi et al., 1993; Gould et al., 1992) e do cortisol aumentado reduzir os níveis de NFs e MAP2 (Cereseto et al., 2006). O aumento de SYN em EX7 corrobora com a hipótese de que o aumento da corticosterona não anulou a plasticidade hipocampal. 
Em conclusão, as mudanças que observamos nos níveis protéicos de SYN, NF68, MAP2 e GFAP como resultado de diferentes tempos de exercício sugerem um efeito positivo do exercício moderado em esteira por curtos períodos na plasticidade hipocampal, que ocorreu, de forma geral, independentemente de regulação transcricional e de regulação positiva do BDNF. Além disso, este protocolo se mostrou suficiente para aumentar a neurogênese hipocampal adulta após apenas 3 dias de exercício.

\subsubsection{Efeitos do Exercício em Regiões Motoras do EncÉfalo de Ratos}

Com o objetivo de estudar proteínas sinápticas e do citoesqueleto em regiões motoras do encéfalo, observamos que o protocolo de exercício moderado de curta duração utilizado induziu aumentos dos níveis protéicos de todas as proteínas estudadas (SYN, SYP e NFs) nestas regiões e que os efeitos foram diferentes entre as proteínas, região estudada e curso temporal do exercício. Considerando as funções destas proteínas (resumidas anteriormente), nossos dados podem sugerir que as mudanças de SYN e SYP podem estar relacionadas a ajustes da eficiência sináptica, enquanto que as mudanças dos NFs podem refletir um remodelamento neuronal que pode estar relacionado à plasticidade e eficiência sináptica. Nossos resultados apontam para ajustes do sistema nervoso pela reorganização funcional de circuitos motores, possivelmente envolvendo processos de remodelamento sináptico e neuronal mediados pela regulação positiva e negativa da síntese, degradação e tráfego de proteínas.

De forma geral, pudemos observar que nas regiões motras estudadas, o exercício promoveu mais alterações nos períodos mais curtos de exercício. Isso pode ser devido à adaptação ao protocolo no período mais tardio e/ou à novidade da intervenção nos períodos mais curtos. Houve, contudo, mudanças de RNAms mais tardias no estriado e no córtex, mas estas mudanças podem ser compensatórias após mudanças dos níveis protéicos nos períodos mais curtos. A principal exceção para esta regra foi a formação reticular do tronco encefálico, onde observamos as principais alterações após longos períodos de exercício e todas as alterações foram restritas aos NFs. Nos parágrafos a seguir, cada região motora será discutida separadamente com o intuito de identificar efeitos específicos do exercício sobre essas regiões envolvidas no controle motor. 


\subsubsection{Cerebelo}

Dentre as funções do cerebelo está a integração sômato-sensorial (Manzoni, 2007) e a sinalização para o córtex sobre os movimentos em andamento (BonnefoiKyriacou et al., 1998). Um estudo que avaliou as células de Purkinje demonstrou que ratos submetidos a exercício em esteira durante suas vidas (do $5^{\circ}$ ao $23^{\circ}$ mês de vida, duas vezes por dia por 20 minutos a $20 \mathrm{~m} / \mathrm{min}$ ) tinham o mesmo número de células que ratos jovens, enquanto que os ratos que envelheciam sem exercício apresentavam $11 \%$ menos células e o soma destas células encontrava-se reduzido em 9\% (Larsen et al., 2000). Um aumento de FSC também foi observado no cerebelo de ratos que faziam exercício em esteira (Holschneider et al., 2003).

Algumas formas de aprendizado motor dependem da depressão de longo prazo (LTD) do cerebelo (Ito, 1989), que geralmente envolve a modulação de receptores de glutamato tipo AMPA (Matsuda et al., 2000). Foi observado que o exercício em esteira preservou a coordenação motora até um certo ponto após oclusão transiente da artéria cerebral média, e promoveu aumento da proteína associada ao sinaptossoma $25-\mathrm{kDa}$ e da proteína GFAP no cerebelo de ratos. Estes resultados apóiam a hipótese de que ocorre angiogênese e remodelamento de conexões sinápticas induzidas pelo exercício (Mizutani et al., 2010). Nossos resultados no cerebelo mostraram aumento dos níveis das proteínas SYN e NF68, que apontam para um possível aumento da atividade sináptica no cerebelo e sugerem que o exercício pode promover processos plásticos além da LTD. No entanto, não observamos mudanças na expressão do RNAm para os genes estudados, sugerindo que os aumentos de proteína observados podem ser devido a mudanças na metabolização das proteínas.

\subsubsection{Substância Negra}

A substância negra e suas conexões com os demais núcleos da base via estriado são de fundamental importância para a manutenção do movimento normal. Os aumentos dos níveis protéicos do NF68 e NF160 em EX3 podem indicar uma regulação positiva da síntese protéica seguida do remodelamento axonal após períodos mais longos de exercício. Observamos também aumentos da expressão do RNAm para SYN e SYP, sugerindo fortemente um aumento da plasticidade nesta região, sem diferenças detectáveis dos níveis protéicos. Estas mudanças podem ter 
ocorrido nas conexões da substância negra pars compacta com o estriado ou da substância negra pars reticulata com o tálamo, colículo superior ou núcleo pedúnculo-pontino (Paxinos, 2004). É importante ressaltar que apenas alguns circuitos dos núcleos da base tem funções estritamente motoras, enquanto que outros estão envolvidos em aspectos da memória e funções cognitivas, que também pode ser influenciados pelo exercício.

\subsubsection{Estriado}

O estriado é responsável pelo aprendizado do sequenciamento motor e pelo automatismo de movimentos em fases tardias (Doyon et al., 2009; Holschneider et al., 2003, 2007). Há evidências da ativação do estriado após exercício em esteira (7 dias, $20 \mathrm{~min} /$ dia a $36 \mathrm{~m} / \mathrm{min}$ ), revelado pelo aumento da expressão da proteína Fos na maioria das regiões do estriado (Liste et al., 1997). Utilizando outro protocolo de exercício (exercício em esteira por 2 semanas, $20 \mathrm{~min} /$ dia a $60 \%$ do consumo máximo de $\mathrm{O}_{2}$ ), contudo, não possível identificar mudanças no sistema antioxidante celular ou nos níveis de BDNF no estriado ou em outras regiões do encéfalo (Cechetti et al., 2008). Estes estudos apóiam nossa hipótese de que para alguns sistemas, períodos mais curtos de exercício provocam adaptações mais intensas, sugerindo a participação destes sistemas na plasticidade de curto prazo.

Como visto em outras regiões analisadas, as mudanças ocorridas no estriado após períodos mais curtos de exercício confirmam nossa idéia de que o exercício promove plasticidade em períodos mais curtos de exercício seguido da adaptação à condição do exercício, estacionando assim os processos plásticos. Nós observamos que os aumentos dos níveis das proteínas SYN em EX3 e EX7 foi acompanhado pelo aumento da expressão do seu RNAm apenas em EX3, o que pode indicar que este sistema já está retornando a níveis basais em EX7 devido à adaptação ao estímulo. Diante de um aumento da síntese protéica nos períodos iniciais do exercício, o sistema pode ter reduzido a expressão de RNAm para contrabalancear o aumento dos níveis de proteína, retornando a síntese protéica para níveis basais. Outros achados que apóiam esta hipótese são o nível aumentado de SYP em EX7 seguido da redução da expressão do seu RNAm em EX15 e o nível aumentado de NF68 em EX3 seguido da redução da expressão do seu RNAm em EX7 e EX15. Este aumento dos níveis de SYP no estriado pode ter ocorrido devido a uma 
liberação aumentada de glutamato que está diretamente ligada à fosforilação da SYP, sugerindo uma possível LTP (Evans e Cousin, 2005). É importante ressaltar que, além da mudança da expressão do RNAm para SYP na substância negra, o estriado foi a única outra região analisada em que observamos mudanças da SYP. Isso possivelmente indica que a SYP pode não estar envolvida diretamente nos processos plásticos afetados por este protocolo de exercício em outras regiões do encáfalo. Alternativamente, as técnicas empregadas aqui podem não ter sido sensíveis o suficiente para detectar mudanças da SYP em algumas áreas.

\subsubsection{Córtex Motor}

Não esperávamos encontrar muitas mudanças no nível cortical, já que o exercício em esteira deve ser automatizado relativamente rápido e deve estimular predominantemente outras regiões motoras (Marder e Bucher, 2001). Todavia, existem evidências de aumento do FSC no córtex motor e sômato-sensorial após exercício em esteira (Holschneider et al., 2003), assim como do aumento da atividade neuronal em áreas motoras durante o exercício (Vissing et al., 1996). De acordo com Holschneider e Maarek (2008), o exercício aumenta a atividade do córtex olfatório, piriforme e motor secundário, assim como de áreas amigdalóides. Esta ativação sugere que imediatamente após a colocação do rato na esteira, ocorre um aumento da atenção focada na novidade olfativa, do exploratório associado e do componente emocional. Por outro lado, a possível atenuação da ativação do córtex motor em períodos mais tardios pode ter ocorrido devido à habituação. Ao invés disso, observamos aqui uma redução de NF68 e NF160 em EX3, seguida do aumento apenas da proteína NF68 em EX15, o que pode ser explicado pelo remodelamento e mudanças no estado de fosforilação destas proteínas na ausência de mudança na expressão de RNAms. As implicações funcionais destes achados ainda não são claras.

\subsubsection{Formação reticular do tronco encefálico}

A grande variedade anátomo-funcional de núcleos nesta região (Brodal, 1981) provavelmente diluiu possíveis variações dos níveis das proteínas de vesículas estudadas. Por outro lado, os níveis protéicos de todos os NFs aumentaram significativamente em EX15. Este efeito mais tardio do exercício nesta região 
encefálica provavelmente se deve a função de algumas estruturas da formação reticular na manutenção do tônus, equilíbrio e postura, especialmente durante movimentos (Ángeles Fernández-Gil et al., 2010; Jahn e Zwergal, 2010). Já as mudanças dos RNAms para estas proteínas ocorreram de forma geral mais cedo, possivelmente representando uma ação antecipatória para preparar o remodelamento que se seguiu. O RNAm para NF160 aumentou em todos os períodos do exercício, implicando uma maior participação desta subunidade no remodelamento ocorrido na formação reticular decorrente do exercício. Já o RNAm para NF68 aumentou apenas em EX7.

As alterações observadas nos níveis protéicos e na expressão de RNAm para SYN, SYP e NFs indicam que o exercício moderado de curta duração pode induzir plasticidade em regiões do encéfalo ligadas à função motora e que são comumente afetadas por doenças neurodegenerativas ou lesões do sistema nervoso. Identificar mecanismos responsáveis por estes efeitos nas diversas regiões do encéfalo pode ser de grande utilidade no planejamento de estratégias terapêuticas. 


\section{* CAPÍTULO 3}

\section{AVALIAÇÃO DOS EFEITOS DO EXERCÍCIO FÍSICO SOBRE A UNIDADE/COMUNICAÇÃO NEUROVASCULAR NO ENCÉFALO DE RATOS}

\subsection{ATIVAÇÃO NEURONAL E O FLUXO SANGUÍNEO CEREBRAL (FSC)}

Diante dos inúmeros efeitos benéficos que o exercício proporciona ao encéfalo, pode-se postular que ele pode promover ativação neuronal não só em regiões diretamente ligadas a atividade motora, mas também em regiões sem relação direta com a função motora como, por exemplo, o hipocampo (Nishijima e Soya, 2006). Neurônios em atividade precisam receber um aporte adequado de oxigênio e de glicose, porém de forma restrita em relação ao tempo e ao local onde ocorre o aumento da atividade (Filosa et al., 2004). Foi observado que ocorre um aumento na atividade metabólica no hipocampo de ratos submetidos a protocolos de exercício, ocorrendo aumento na utilização de glicose pelo encéfalo em diversas regiões, sendo que no hipocampo este aumento foi de $29 \%$ (Vissing et al., 1996). A ativação neuronal foi observada também através de marcação para c-Fos (marcador de atividade neuronal) onde observou-se que exercícios de maior intensidade promovem maior atividade neuronal; porém, em um protocolo de exercício leve, a expressão de c-Fos aumentou apenas até $07^{0}$ dia de corrida, decaindo subsequentemente (Lee et al., 2003).

Considerando a teoria primeiramente descrita por Roy e Sherrington (1890) de que a atividade neuronal está diretamente associada ao FSC, supõe-se que ocorre hiperemia funcional (aumento de FSC em resposta à ativação neuronal) no hipocampo de ratos durante o exercício. Utilizando fluxometria laser-Doppler, Osborne (1997) observou aumento do FSC no hipocampo de ratos durante atividades comportamentais e durante o exercício. Nishijima e Soya (2006) confirmaram esta hipótese demonstrando aumento do FSC no hipocampo de ratos submetidos a um protocolo de corrida leve em esteira. Para confirmar que este aumento do FSC ocorreu devido à ativação neuronal, foi infundido um bloqueador de canal para $\mathrm{Na}^{2+}$ por microdiálise e este bloqueador suprimiu completamente o 
aumento do FSC no local da infusão. Também foi observado que ratos submetidos a exercícios em esteira apresentaram maior radioatividade tecidual relacionada ao FSC em áreas motoras (como córtex motor primário, estriado dorsolateral, tálamo ventrolateral e cerebelo) no córtex sômato-sensorial e no córtex visual secundário (Holschneider et al., 2003).

Há duas hipóteses a respeito de como a ativação neuronal provoca alterações no FSC. A primeira considera o controle direto dos neurônios sobre o FSC através da extensa inervação presente nos vasos sanguíneos cerebrais (Reinhard et al., 1979; Vaucher e Hamel, 1995; Krimer et al., 1998). A microvasculatura parenquimal é inervada por interneurônios e terminais neuronais de origem central (inervação intrínseca) (Cohen et al., 1996; ladecola, 1998), enquanto os vasos extracerebrais são inervados por nervos periféricos (inervação extrínseca) (Gulbenkaian et al., 2001).

Já a segunda hipótese considera que a dilatação local de arteríolas em resposta à alta atividade neuronal se deve primordialmente à ativação de astrócitos pela liberação local de neurotransmissores (Zonta et al., 2003). Uma das principais funções dos astrócitos é rapidamente coletar transmissores que são liberados por neurônios na fenda sináptica durante a transmissão de sinal. Porém astrócitos também expressam receptores para neurotransmissores e respondem à atividade neuronal com aumentos na concentração citosólica de $\mathrm{Ca}^{2+}\left(\left[\mathrm{Ca}^{2+}\right] \mathrm{i}\right)$ (Anderson e Nedergaard, 2003).

Esta segunda hipótese se baseia nas seguintes observações: os astrócitos fazem contato próximo tanto com as sinapses quanto com as arteríolas cerebrais (Fig.3-1); os astrócitos respondem à liberação sináptica de glutamato (pela ativação de receptores metabotrópicos de glutamato - mGluRs) com oscilações na concentração intracelular de cálcio $\left(\left[\mathrm{Ca}^{2+}\right]_{\mathrm{i}}\right)$; e as elevações na $\left[\mathrm{Ca}^{2+}\right]_{i}$ nos astrócitos ativam a liberação de substâncias vasoativas (Zonta et al., 2003). Foi observado por Zonta et al. (2003) que, na presença de antagonistas de mGluRs (LY367385 ou MPEP), as elevações da [ $\left.\mathrm{Ca}^{2+}\right]_{i}$ nos astrócitos, mas não nos neurônios, são inibidas, sendo também comprometida a vasodilatação dependente de atividade neuronal. Observaram também que a ativação da elevação da $\left[\mathrm{Ca}^{2+}\right]_{i}$ nos astrócitos pelo uso de agonistas de mGluRs (t-ACPD) promoveu dilatação das arteríolas, mesmo na presença de um bloqueador de atividade neuronal (TTX - tetrodotoxina) e de um bloqueador da liberação de neurotransmissor (TeNT - toxina tetânica). Esta foi a 
primeira evidência in situ de que o aumento $\left[\mathrm{Ca}^{2+}\right]_{i}$ no astrócito liga a atividade sináptica ao controle do tônus microvascular (Zonta et al., 2003). Este conjunto de achados confirma que o astrócito desempenha papel fundamental no controle do FSC.

Além disso, foi observado por Filosa et al. (2004) que o aumento de $\mathrm{Ca}^{2+}$ mediado pela atividade neuronal, em astrócitos corticais, depende de canais de $\mathrm{Ca}^{2+}$ voltagem-dependentes presentes na membrana celular e no retículo endoplasmático. Após demonstrarem pela primeira vez a sinalização rápida do neurônio para o vaso in situ, consistente com a hiperemia funcional in vivo, observaram que o aumento da $\left[\mathrm{Ca}^{2+}\right]_{i}$ no astrócito se deve a liberação de estoques de $\mathrm{Ca}^{2+}$ intracelular mediada por receptores de inositol trisfosfato $\left(\mathrm{IP}_{3} \mathrm{R}\right)$ (Filosa et al., 2004). Observaram também que os canais de $\mathrm{Ca}^{2+}$ dependentes de voltagem do tipo L podem modular a comunicação neurônio-vaso (Filosa et al., 2004).

A ativação dos astrócitos via mGluRs diminui significativamente a frequência das oscilações de $\mathrm{Ca}^{2+}$ em arteríolas parenquimais, diminuindo a vasomotricidade destas (Filosa et al., 2004). Os astrócitos atuam sobre os vasos pelos pés terminais liberando substância vasoativas, como NO, prostaciclinas, ácidos graxos saturados, glutamato, adenosina, ATP e K ${ }^{+}$(Filosa et al., 2004). Estas substâncias apresentam papéis variáveis na dependência da região do encéfalo onde são liberadas. O NO, por exemplo, desempenha papel crucial no acoplamento neuro-vascular no cerebelo (Yang et al., 1999), enquanto que no córtex atua apenas como fator modulador (Lindauer et al., 1999). O mecanismo de ação destas substâncias também é variado. Por exemplo, $\circ \mathrm{K}^{+}$, quando apresenta elevações modestas da sua concentração extracelular, ativa canais de $\mathrm{K}^{+}$retificadores ocasionando hiperpolarização do potencial de membrana das células do músculo liso de arteríolas intracerebrais, induzindo vasodilatação e supressão das oscilações da $\left[\mathrm{Ca}^{2+}\right]_{i}$ na célula muscular lisa (Filosa et al., 2006). 


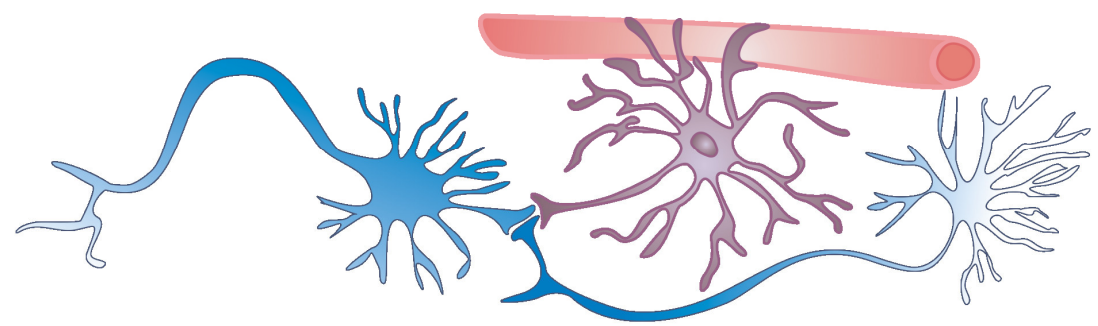

Figura 3-1. Ilustração dos componentes básicos da unidade neurovascular: neurônios (azul), astrócito perivascular e seus pés terminais (roxo) e arteríola (rosa).

FONTE: adaptado de Allen e Barres, 2009.

\subsection{ASTRÓcITOS}

Centralmente, a glia é formada pela macroglia (oligodendrócitos e astrócitos) e pela microglia (Haydon, 2001). Os astrócitos constituem cerca de $50 \%$ das células gliais (Kimelberg, 1983), contribuindo para a homeostasia e para a regulação de concentrações de íons $\mathrm{K}^{+}$(Araque et al., 2001; Perea e Araque, 2002). Este equilíbrio entre os níveis aquosos e de íons $\mathrm{K}^{+}$se dá pela ação coordenada de canais Kir e de aquaporinas (Aqp4), prevenindo o acúmulo prejudicial de $\mathrm{K}^{+} \mathrm{e}$ glutamato no meio extracelular e dissipando estas moléculas pelas gap junctions (Seifert et al., 2006).

Diversas evidências têm demonstrado a existência de interação entre astrócitos e neurônios (Araque et al., 2001; Perea e Araque, 2002). Astrócitos protoplásmaticos (presentes na massa cinzenta) estão associados com o corpo celular neuronal e sinapses, enquanto que astrócitos fibrosos (presentes na massa branca) estão associados aos axônios neuronais (Allen e Barres, 2009). Algumas destas evidências são baseadas em estudos empregando células em cultura e mostraram que neurotransmissores liberados por neurônios induzem, nos astrócitos, aumento dos níveis intracelulares de $\mathrm{Ca}^{2+}$, com consequente liberação de glutamato. O glutamato, uma vez liberado, modula a excitabilidade neuronal e facilita a transmissão sináptica (Haydon, 2001). Além da ativação por mGluRs, ocorre também aumento na $\left[\mathrm{Ca}^{2+}\right]_{i}$ nos astrócitos através da ativação de iGluRs, GABA-B e receptores de acetilcolina (Seifert et al., 2006). Os astrócitos também realizam a remoção de neurotransmissores liberados por neurônios ativos. No caso do glutamato, esta remoção é realizada por dois transportadores gliais específicos: 
EAAT1 ou GLAST e EAAT2 ou GLT1 (Seifert et al., 2006). Foi demonstrado também que por seus processos finos os astrócitos conseguem atingir milhares de sinapses sincronizando padrões de disparo (Seifert et al., 2006). Os astrócitos se comunicam por ondas de $\mathrm{Ca}^{2+}$, propagando informação para longas distâncias. A estimulação de um astrócito pode causar respostas em uma população vizinha de astrócitos e não em outra, indicando a existência de redes de astrócitos distintas. Estas células são ligadas entre si por gap junctions (Allen e Barres, 2009).

A participação dos astrócitos na comunicação neuro-vascular sugere, portanto, um novo e importante papel dos astrócitos na função do sistema nervoso (Zonta et al., 2003).

\subsection{SISTEMA ENDOTELINÉRGICO NOS ASTRÓCITOS}

Os astrócitos influenciam a circulação cerebral, porém do lado da adventícia as endotelinas também atuam nos vasos sanguíneos cerebrais (Ehrenreich et al., 1999). Endotelina 1 (ET-1) é um potente vasoconstrictor, mas também induz a produção de um potente vasodilatador, o óxido nítrico (NO). Ao se ligar ao receptor de endotelina tipo $B\left(E T_{B} R\right)$ em células endoteliais, a ET-1 inicia uma cascata de sinalização que leva à produção de NO que, por sua vez, inibe a ET-1 no nível da sua transcrição. $\mathrm{Na}$ ausência da ativação dos receptores de endotelinas, o NO provoca vasodilatação. Quando ocorre ativação dos receptores de endotelina, há formação de IP3, o que causa a liberação de $\mathrm{Ca}^{2+}$ pelo retículo sarcoplasmático (Klabunde, 2004).

A ET-1 e a ET-3 foram identificadas no encéfalo de humanos e ratos por autoradiografia e RT-PCR (Blomstrand et al., 1999). No encéfalo, estes peptídeos são produzidos por células endoteliais e neurônios, mas são expressos em astrócitos em algumas situações como astrócitos ativados in vivo e em astrócitos em cultura (Blomstrand et al., 1999). Os sítios de ligação das endotelinas (ETs) encontram-se amplamente distribuídos no encéfalo, porém em maiores concentrações na formação hipocampal e no cerebelo (Blomstrand et al., 1999). Os efeitos da ET-1 e ET-3 sobre o sistema nervoso central envolvem o aumento do consumo de glicose, aumento do efluxo de glutamato, estimulação de proliferação e mitogênese, aumento da expressão de c-fos e NGF, regulação da atividade de 
canais iônicos, mobilização de várias vias de transdução e desencadeamento de ondas intracelulares de $\mathrm{Ca}^{2+}$ (Blomstrand et al., 1999).

Mais especificamente nos astrócitos, as ETs atuam alterando padrões de sinalização do $\mathrm{Ca}^{2+}$, desencadeando ondas intracelulares de $\mathrm{Ca}^{2+}$ e inibindo a permeabilidade de gap junctions e a propagação de sinais (Blomstrand et al., 1999). Os níveis de comunicação intercelular entre astrócitos podem ser "desligados" quando os níveis de ETs se encontram elevados no encéfalo (Blomstrand et al., 1999). Tanto ET-1 quanto ET-3 podem modular a função astrocítica por alterações sutis do padrão de sinalização do $\mathrm{Ca}^{2+}$ (Ehrenreich, 1999), podendo ocorrer ativação, proliferação e diferenciação mediadas por aumentos de $\mathrm{Ca}^{2+}$ no citosol (Ehrenreich et al.,1999). Estes peptídeos geram padrões de resposta diferentes e podem influenciar a comunicação astrocítica, por exemplo promovendo homeostase metabólica, propagação de sinais apoptóticos ou modulação da eficiência e direção da transcrição gênica (Ehrenreich, 1999).

A ET-3 age sobre o receptor de endotelina tipo $B\left(E T_{B} R\right)$ e a ET-1 pode agir tanto sobre o $E T_{B} R$ quanto sobre o receptor de endotelina tipo $A\left(E T_{A} R\right)$ (Ehrenreich, 1999), ambos receptores ligados a proteína G (Barton e Yanagisawa, 2008) (Fig.32). $O E T_{A} R$ é mediador de vasoconstricção, é expresso principalmente em células vasculares e tem maior afinidade pela ET-1 (ET-1 $\geq$ ET-2 >> ET-3) (Blomstrand et al., 1999). Já o $E T_{B} R$ é mediador de vasodilatação, é expresso principalmente em células gliais (Blomstrand et al., 1999) e tem afinidade por todas as endotelinas (Blomstrand et al., 1999; Barton e Yanagisawa, 2008). Este é responsável por elevações rápidas no $\left[\mathrm{Ca}^{2+}\right]_{i}$, contrabalanceia a vasoconstricção mediada pelo $\mathrm{ET}_{\mathrm{A}} \mathrm{R}$ e inibe a atividade da enzima conversora de endotelina (ECE) (Ehrenreich et al., 1999). No sistema vascular, o $E T_{B} R$ inibe o crescimento celular e a vasoconstricção, atuando também como um receptor de clearance, uma vez que faz o clearance da ET-1 circulante (Barton e Yanagisawa, 2008).

No trauma neurológico, observa-se diminuição da expressão de $E T_{B} R$ vascular acompanhada pela diminuição da vasodilatação mediada por endotelinas e paralelamente ocorre um aumento da expressão de $\mathrm{ET}_{\mathrm{B}} \mathrm{R}$ em astrócitos (Ehrenreich, 1999). O aumento de $E T_{B} R$ nos astrócitos serve de alvo para os elevados níveis extracelulares de ET-1 e ET-3 (Ehrenreich, 1999). Em ratos deficientes de ET $R$, observa-se aumento da atividade da ECE-1 e do nível extracelular de ET-1 (até $356 \%$ ). Nestes animais, em condições basais os níveis de $\left[\mathrm{Ca}^{2+}\right]_{\mathrm{i}}$ nos astrócitos não 
se encontravam alterados, porém quando se acrescentava ET-1, estes níveis encontravam-se mais elevados quando comparados aos dos ratos wild-type (Ehrenreich et al.,1999).

Devido à multiplicidade das funções do sistema endotelinérgico no encéfalo, incluindo neurotransmissão, neuromodulação e angiogênese, nós avaliamos os efeitos do exercício sobre a potencial ação destes peptídeos na unidade neurovascular.

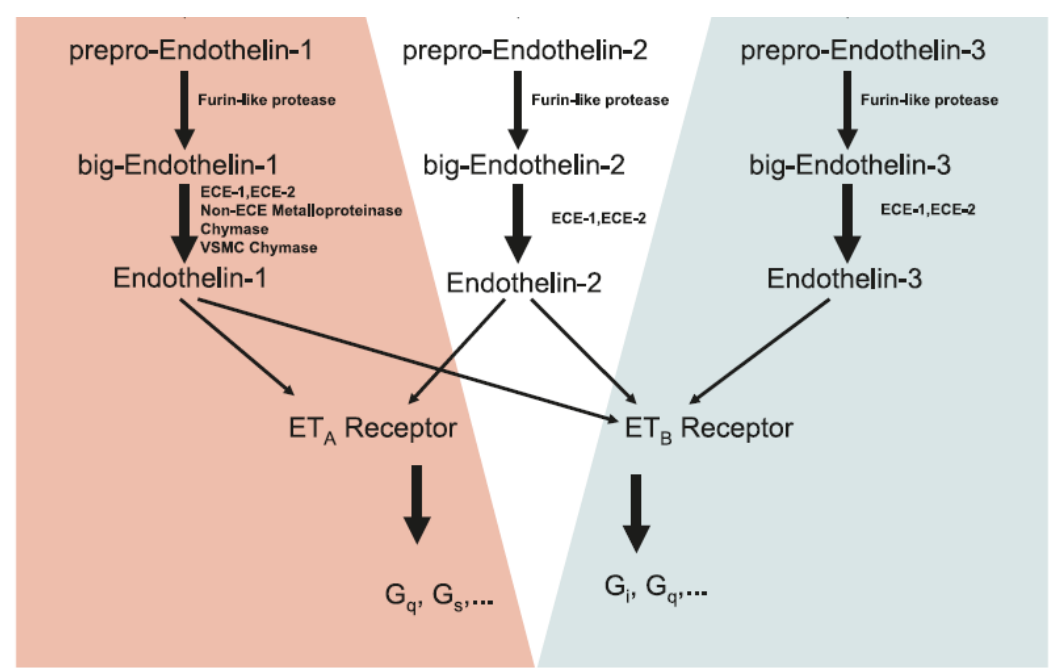

Figura 3-2. Esquema ilustrativo da conversão das endothelinas e a ação destas sobre receptores específicos.

FONTE: adaptado de Barton e Yanagisawa, 2008.

\subsection{JUSTIFICATIVA E OBJETIVOS}

Tendo em vista que o exercício físico traz inúmeros benefícios para o sistema nervoso e que a sua prática promove, por maior ativação neuronal, um aumento do FSC local mediado por astrócitos, o estudo de sinapses funcionalmente mais ativas e seus efeitos sobre os astrócitos e consequentemente sobre o FSC local podem contribuir para a compreensão dos mecanismos pelos quais o exercício beneficia o sistema nervoso central.

Os objetivos deste estudo visaram determinar se o exercício físico moderado de curto período resulta em alterações funcionais e estruturais da unidade neurovascular pela avaliação da dinâmica do $\mathrm{Ca}^{+2}$ no sistema endotelinérgico dos astrócitos corticais, da estrutura da unidade neurovascular com relação à densidade 
dos processos dos astrócitos e à densidade vascular, e a expressão de GFAP e de receptores $\mathrm{ET}_{\mathrm{B}}$ no córtex de ratos.

\subsection{MATERIAL E MÉTODOS}

\subsubsection{ANImais}

Foram utilizados nos experimentos ratos machos da linhagem Wistar (28 \pm 2 dias de idade) fornecidos pelo biotério do Medical College of Georgia (Augusta, GA, EUA). Os animais foram mantidos em uma sala com temperatura constante de $23^{\circ} \mathrm{C}$ e ciclo claro / escuro artificialmente controlado de 12/12h, tendo livre acesso à alimentação e água. Todos os procedimentos foram realizados de acordo com o comitê de ética para pesquisa animal do Medical College of Georgia e com o guia de cuidados com animais do National Institutes of Health (NIH/EUA).

\subsubsection{Protocolo de EXERcícIo}

Após um período de adaptação de 3 dias à esteira para ratos (Animal treadmill Exer 3/6: Columbus Instruments, Columbus, OH, EUA) (Fig.3-3), os ratos que se adaptaram bem à esteira foram divididos em grupo controle $(C)$ e grupo exercício (EX). Durante o período de adaptação, os animais eram colocados na esteira para explorar o equipamento e em seguida esta era ligada por 15 minutos, iniciando com velocidade de $0,3 \mathrm{~km} / \mathrm{h}$ e evoluindo até $0,5 \mathrm{~km} / \mathrm{h}$. Após este período, o grupo EX correu por 45 minutos por dia a $0,6 \mathrm{~km} / \mathrm{h}(10 \mathrm{~m} / \mathrm{min})$ por duas semanas, 5 dias por semana. Ao final do protocolo os animais tinham 42 a 46 dias de idade. Todos os treinamentos foram realizados no início do ciclo ativo dos animais (entre $18 \mathrm{pm}$ e 20pm) enquanto os animais sedentários eram apenas manuseados, permanecendo em suas caixas ao lado da esteira. 


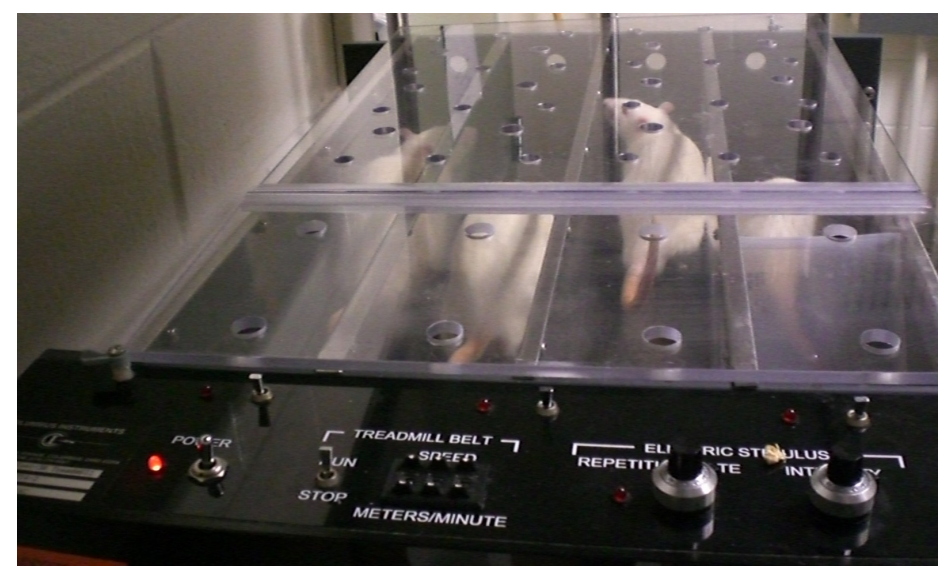

Figura 3-3. Esteira para ratos (Animal treadmill Exer 3/6: Columbus Instruments, Columbus, $\mathrm{OH}$, EUA).

\subsubsection{Protocolo de Fatias}

Os animais foram anestesiados com pentobarbital (100mg/kg i.p.) e rapidamente sacrificados por decapitação. Os encéfalos foram rapidamente removidos e posicionados sobre um vibrátomo (Leica VT 1200S - Leica Microsystems, Wetzlar, Germany) utilizado para cortar fatias coronais de aproximadamente $250 \mu \mathrm{m}$ de espessura em líquido cérebro-espinhal artificial (aCSF) a uma temperatura de $4^{\circ} \mathrm{C}$ a $6^{\circ} \mathrm{C}$. A composição do aCSF (em mmol/L) consta de 3 $\mathrm{KCl}, 120 \mathrm{NaCl}, 1 \mathrm{MgCl}_{2}, 26 \mathrm{NaHCO}_{3}, 1,25 \mathrm{NaH}_{2} \mathrm{PO}_{4}, 10$ glicose, 2,4 $\mathrm{CaCl}_{2}$, e 400 $\mu \mathrm{mol} / \mathrm{L}$ ácido $\mathrm{L}$-ascórbico (osmolaridade final de $\approx 300 \mathrm{mosM}$ ), equilibrado com $95 \%$ de $\mathrm{O}_{2}$ e $5 \%$ de $\mathrm{CO}_{2}$. O ácido ascórbico foi adicionado à solução para reduzir o edema celular associado ao estresse oxidativo. As fatias foram imediatamente incubadas a temperatura ambiente em aCSF equilibrado com $95 \%$ de $\mathrm{O}_{2}$ e $5 \%$ de $\mathrm{CO}_{2}, \mathrm{pH} \approx 7.45$, até o uso (Filosa et al., 2004).

\subsubsection{Protocolo de Imageamento de $\mathrm{CA}^{2+}$}

Imagens de $\mathrm{Ca}^{2+}$ foram obtidas utilizando o sistema Andor Technology Revolution (câmera iXON EMCCD com a unidade de escaneamento confocal Yokogawa CSU10). A unidade confocal foi acoplada a um microscópio Zeiss (Axioscope 2FS). As fatias corticais foram incubadas à temperatura ambiente em aCSF contendo Fluo-4 AM $(4 \mu \mathrm{l} / \mathrm{ml})$ e ácido plurônico $(2,5 \mu \mathrm{l} / \mathrm{ml})$ (ambos da Invitrogen - Molecular Probes, Inc., Eugene, OR, EUA). Após um período de incubação de 2 
horas, as fatias foram lavadas e mantidas em aCSF a temperatura ambiente até uso. Utilizando este protocolo de carregamento das fatias com Fluo-4 AM foi possível visualizar transientes de $\mathrm{Ca}^{2+}$ em astrócitos, uma vez que os neurônios não carregam o suficiente para detecção de $\mathrm{Ca}^{2+}$ neste protocolo (Peters et al., 2003) (Fig.3-4). No momento do experimento, uma fatia foi transferida para uma câmara de perfusão no microscópio, fixada com uma tela de nylon e constantemente perfundida com aCSF mantido a uma temperatura de $33^{\circ} \mathrm{C}$ a $35^{\circ} \mathrm{C}$. Os astrócitos foram visualizados utilizando uma objetiva $63 X$ de imersão em água. Imagens fluorescentes foram obtidas utilizando estimulação por laser de kriptônio/argônio a $488 \mathrm{~nm}$ e a emissão de luz coletada a $>495 \mathrm{~nm}$. As imagens foram obtidas a 1 quadro por segundo por um período de 5 minutos.

Os experimentos de imageamento de $\mathrm{Ca}^{2+}$ foram analisados utilizando um programa criado pelo Dr. Adrian D. Bonev do Departamento de Farmacologia da Universidade de Vermont, Burlington (Filosa et al., 2004) e em seguida os dados gerados por este programa foram plotados no Axograph X (Sydney, Australia) para análise cinética dos eventos de $\mathrm{Ca}^{2+}$. A fração de fluorescência $\left(F / F_{0}\right)$ foi obtida pela divisão da intensidade da fluorescência na região de interesse $(F)$ pelo valor de fluorescência basal $\left(F_{0}\right)$ determinado a partir de 50 imagens que demonstravam ausência de atividade. A frequência das oscilações de $\mathrm{Ca}^{2+}$ e a amplitude destas foi

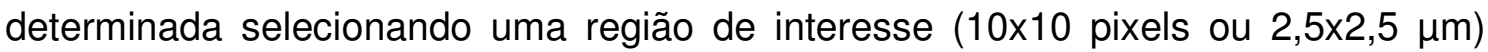
sobre cada célula que apresentou oscilações de $\mathrm{Ca}^{2+}$. Foram considerados os picos com uma faixa de oscilação que ultrapasse um determinado limiar $\left(>1.15 \mathrm{~F} / \mathrm{F}_{\mathrm{o}}\right)$.

Para avaliação do sistema endotelinérgico astrocítico foram utilizados para estimulação dos astrócitos os peptídeos ET-1 e ET-3 (American Peptide Company Inc., Sunnyvale, CA, EUA) e o agonista do receptor $E T_{B} R$, a sarafotoxina 6c (S6c) (Calbiochem - EMD Chemicals Inc. Gibbstown, NJ, EUA). Após 1 minuto de perfusão com aCSF na câmara de perfusão (para registro da linha de base), cada fatia cortical foi perfundida com uma das drogas a 100nM em aCSF por 1 minuto. 


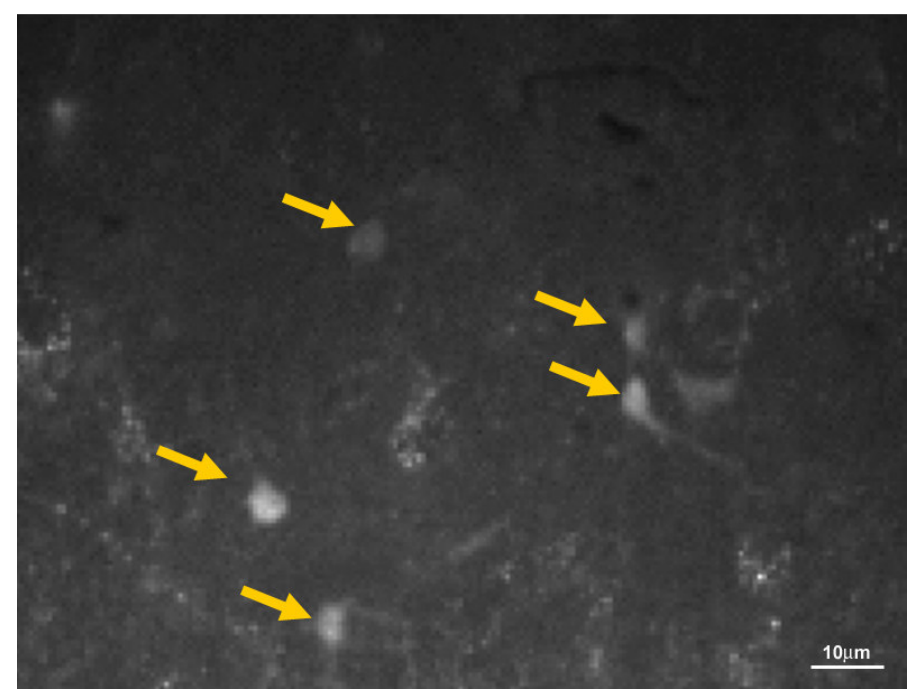

Figura 3-4. Imagem de astrócitos corticais carregados com Fluo-4 AM adquirida através do sistema Andor Technology Revolution.

\subsubsection{INJEÇÕES DE FLUORESCEIN ISOTHIOCYANATE-DEXTRAN (FITC-DEXTRAN)}

Injeções de FITC-Dextran (FD-2000S, Sigma-Aldrich Corp. St. Louis, MO, EUA) foram aplicadas na veia jugular esquerda segundo protocolo adaptado de Cavaglia et al. (2001). O marcador foi diluído a $50 \mathrm{mg} / \mathrm{mL}$ e a dose aplicada de acordo com o peso do rato $(1,43 \mu \mathrm{L} / \mathrm{g})$ que estava profundamente anestesiado com pentobarbital (100mg/kg i.p.). Após aplicada lentamente a injeção, o animal permanecia vivo com o marcador circulando por 8 minutos e em seguida era sacrificado por decapitação. Os encéfalos foram rapidamente coletados, pós-fixados em PFA $4 \%$ por 48 horas, crioprotegidos em sacarose $30 \%$ por 48 horas, secos e congelados a $-80^{\circ} \mathrm{C}$ até serem seccionados em criostato $(50 \mu \mathrm{m})$.

\subsubsection{Imunofluorescência para Estudo de Densidade Vascular e de Processos Astrocíticos}

Os tecidos dos animais injetados com FITC-Dextran foram lavados em PB (3x10 min) e pré-incubados por 1 hora em soro normal de cavalo (Vector Laboratories, Inc. Burlingame, CA, EUA). Em seguida, os tecidos foram incubados com o anticorpo primário monoclonal contra GFAP (1:10.000) (Millipore, Temecula, CA, EUA) por 48 horas a temperatura ambiente, lavados em PB (3x10min) e incubados com anticorpo secundário anti-camundongo feito em burro conjugado Cy3 
(1:400) (Jackson ImmunoResearch, West Grove, PA, EUA) por 4 horas a temperatura ambiente para marcar os processos dos astrócitos. Por último, os tecidos foram incubados por 15 minutos com o marcador nuclear TOTO-3 iodide (1:10.000) (Molecular Probes, Inc., Eugene, OR, EUA) apenas para facilitar a identificação das camadas corticais a serem estudadas.

\subsubsection{ImUNOFLUORESCÊNCIA PARA EstUdo de COLOCALIZAÇÃo do RECEPTOR ET ${ }_{B} R$ COM} Astrócitos e Vasos

Os encéfalos de animais não-injetados com FITC-Dextran foram rapidamente coletados, pós-fixados em PFA $4 \%$ por 48 horas, crioprotegidos em sacarose $30 \%$ por 48 horas, secos e congelados a $-80^{\circ} \mathrm{C}$ até serem seccionados em criostato $(30 \mu \mathrm{m})$. Após serem lavados em PB (3×10 min), os tecidos foram pré-incubados por 1 hora em soro normal de cavalo (Vector Laboratories, Inc. Burlingame, CA, EUA). Foram utilizados os seguintes anticorpos primários para incubação overnight (14 a 20h): anticorpo monoclonal contra GFAP (1:10.000) (Millipore, Temecula, CA, EUA) e anticorpo S100ß (1:1000) (Millipore, Temecula, CA, EUA) para marcar os processos e corpos dos astrócitos, respectivamente, e anticorpo contra $E T_{B} R$ (1:500) (Alomone Labs Ltd., Jerusalem, Israel). Os tecidos foram então lavados (3x10min) com PB e incubados por 4 horas com os anticorpos secundários anti-camundongo feito em burro conjugado com Cy5 (1:50) e anti-coelho feito em burro conjugado Cy3 (1:250) (Jackson ImmunoResearch, West Grove, PA, EUA). Em seguida, os tecidos foram incubados overnight com o marcador de endotélio isolectin 488 (1:100) (Invitrogen - Molecular Probes, Inc., Eugene, OR, EUA).

\subsubsection{Protocolo de WESTERN BLOTTING}

O córtex dos animais dos grupos exercício e controle foram rapidamente coletados, congelados em nitrogênio líquido e armazenados a $-80^{\circ} \mathrm{C}$ até uso. As amostras foram homogeneizadas em tampão de extração RIPA (Tris- $\mathrm{HCl} 50 \mathrm{mM}$, $\mathrm{NaCl}$ 150mM, NP-40 1\%, Na-deoxycholate 0,25\%) com inibidores de proteases (PMSF 1mM, Leupeptin, Aprotinin, Pepstatin) e fosfatases $\left(\mathrm{Na}_{3} \mathrm{VO}_{4} 1 \mathrm{mM}, \mathrm{NaF} 1 \mathrm{mM}\right)$ para extração das proteínas. O conteúdo protéico foi quantificado utilizando um kit BCA (Pierce - Thermo Fisher Scientific Inc., Rockford, IL, EUA) e as amostras foram

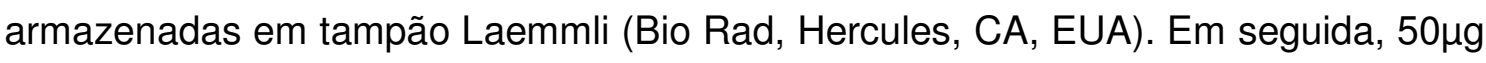


de proteína de cada amostra foram carregadas e separadas em gel SDS-PAGE 8\% e transferidas para membrana de nitrocelulose. As membranas foram bloqueadas por 1 hora em leite desnatado ou BSA $5 \%$ e incubadas overnight a $4^{\circ} \mathrm{C}$ com os mesmos anticorpos primários contra GFAP (1:10.000) e $\mathrm{ET}_{\mathrm{B}} \mathrm{R}$ (1:4.000) utilizados para a técnica de imunofluorescência. As membranas foram então lavadas e incubadas com anticorpos secundários marcador com HRP, anti-camundongo e anticoelho, respectivamente, por 1 hora a temperatura ambiente, lavadas, incubadas com o kit de quimioluminescência e as bandas detectadas pela exposição das membranas ao filme de raio X. A densidade óptica das bandas detectadas foi avaliada utilizando o programa Scion Image for Windows.

\subsubsection{ANÁLISE ESTATíSTICA}

Os dados foram expressos como média \pm SEM. A análise estatística foi realizada utilizando ANOVA de uma via associada ao pós-teste de Tukey para os dados de Imageamento de $\mathrm{Ca}^{2+}$, com exceção dos dados de porcentagens de células onde foi empregado qui-quadrado, e teste t de Student não-pareado para os dados de densidade vascular e de processos astrocíticos, assim como para os dados dos níveis protéicos. Foram considerados estatisticamente significantes os valores de $p<0,05$.

\subsection{RESULTADOS}

\subsubsection{IMAGEAMENTO DE $\mathrm{CA}^{2+}$}

As alterações de $\mathrm{Ca}^{2+}$ nos astrócitos induzidas pelas ETs foram observadas tanto sob forma de aumento sustentado como de aumento oscilatório, porém com predomínio (>90\% das respostas) de aumento sustentado (Fig.3-5 e 3-6). As atividades tanto do $\mathrm{ET}_{\mathrm{A}} \mathrm{R}$ quanto do $\mathrm{ET}_{\mathrm{B}} \mathrm{R}$ foram avaliadas utilizando $\mathrm{ET}-1, \mathrm{ET}-3$ e o agonista específico do $\mathrm{ET}_{\mathrm{B}} \mathrm{R}$, a sarafotoxina 6c (S6c) (Fig.3-6). Inicialmente já foi possível observar que as células de ambos os grupos respondiam mais à $\mathrm{S6c}$ e à ET-3 do que à ET-1 (Fig.3-7). Em relação ao número de células responsivas, observamos também que mais células por fatia respondiam às drogas no grupo exercício em relação ao grupo controle (Fig.3-7). Já na análise cinética das respostas de $\mathrm{Ca}^{2+}$ obtidas, observamos que no grupo que havia realizado exercício, 
a resposta à S6c apresentou maior amplitude do pico da resposta do $\mathrm{Ca}^{2+}$ (Fig.3-8), uma ascensão mais rápida para o pico e uma maior sustentabilidade da resposta (maior área sob a curva da resposta) (Fig.3-9) com relação ao grupo controle. Podese observar também que as respostas do grupo exercício à ET-1 apresentaram-se mais tardias em relação ao grupo controle (Fig.3-10).

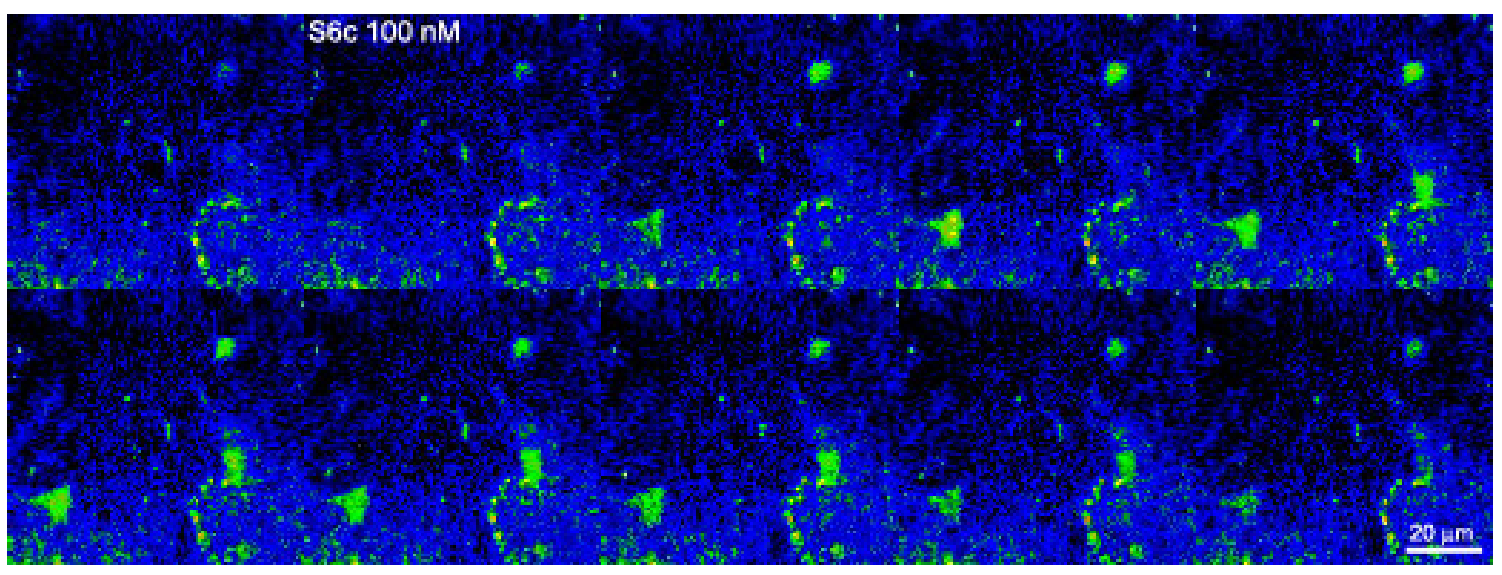

Figura 3-5. Sequência parcial de imagens em pseudo-cor de astrócitos carregados com Fluo-4 AM adquiridas através do sistema Andor Technology Revolution enquanto a fatia cortical era perfundida por aCSF e S6c 100nM por 1 minuto. Pode-se observar o aumento do sinal devido ao aumento de $\mathrm{Ca}^{2+}$ intracelular nos astrócitos e em seguida o início do retorno a níveis basais.

AUMENTO SUSTENTADO DE CÁLCIO

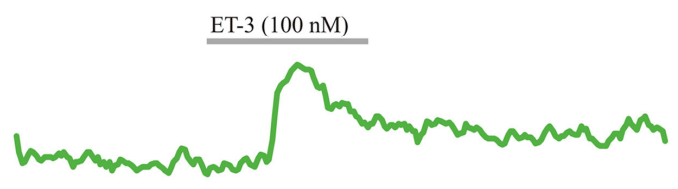

AUMENTO OSCILATÓRIO DE CÁLCIO

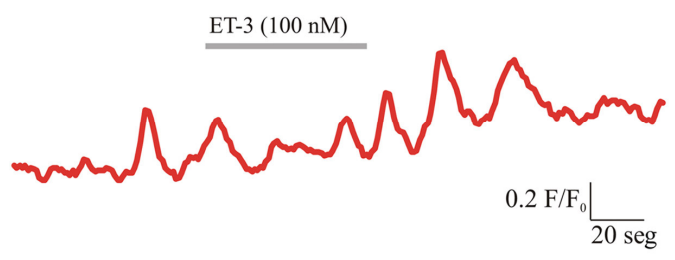

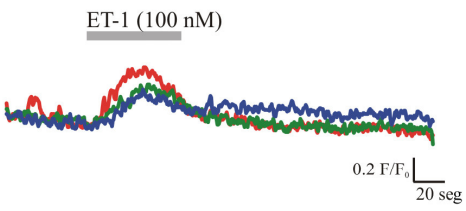
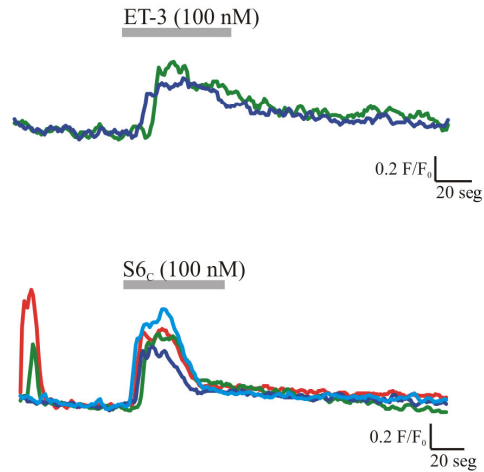

Figura 3-6. Exemplos de padrões de traçados obtidos com as análises de astrócitos estimulados, onde se observa padrão de aumento sustentado de $\mathrm{Ca}^{2+}$ intracelular e padrão oscilatório dos picos de $\mathrm{Ca}^{2+}$ intracelular. Apenas os aumentos sustentados de $\mathrm{Ca}^{2+}$ foram analisados e pode-se observar diferenças na cinética das respostas para as diferentes drogas. ET: endothelina; S6c: sarafotoxina 6c. 
A

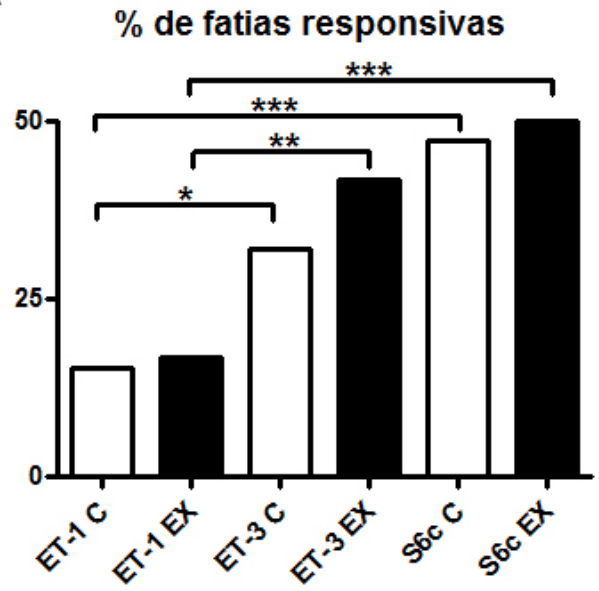

B

$\%$ Células responsivas / fatia

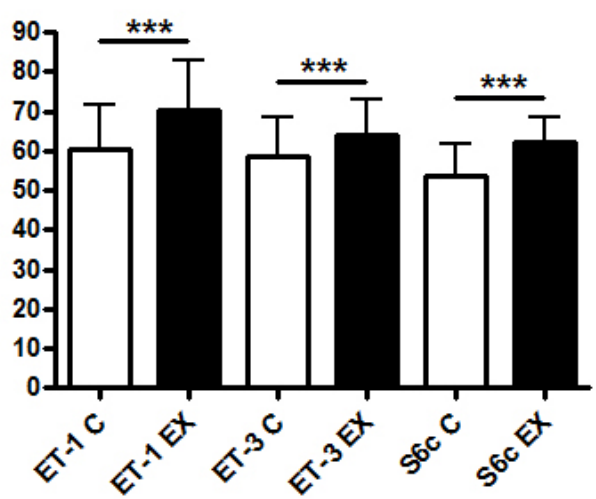

Figura 3-7. Análise quantitativa do número de respostas obtidas nos experimentos de imageamento de $\mathrm{Ca}^{2+}$. (A) Gráfico representando a porcentagem de fatias utilizadas nos experimentos que contínham células responsivas às drogas. Pode-se observar que as células de ambos os grupos respondiam mais à $S 6 c$ e à ET-3 do que à ET-1 ( ${ }^{*} \mathrm{p}<0,05$; ${ }^{* *} p<0,01 ;{ }^{* * *} p<0,001$ ). (B) Gráfico representando porcentagem de células por fatia responsivas e não-responsivas à cada droga. Pode-se observar que mais células por fatia respondiam à todas as drogas no grupo EX que no grupo C. C: grupo controle; EX: grupo exercício; ET: endothelina; S6c: sarafotoxina 6c. $\left({ }^{* * *} p<0,001\right)$.

\section{Amplitude do Pico máximo da resposta do $\mathrm{Ca}^{2+}$}

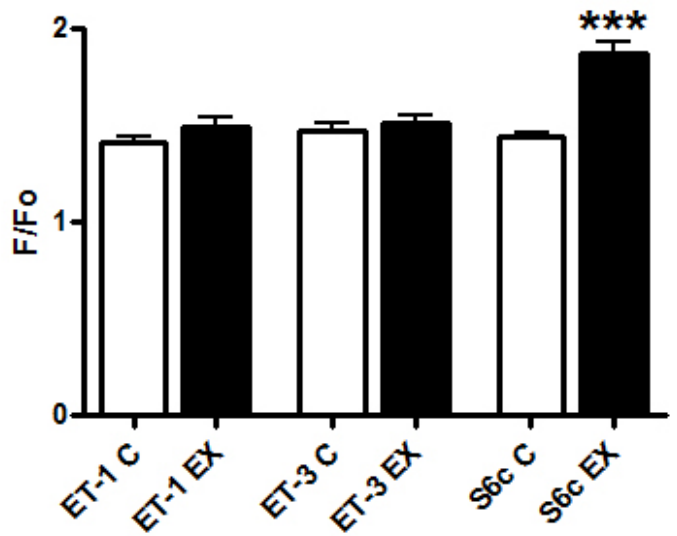

Figura 3-8. Médias das amplitudes máximas atingidas pelo aumento de $\mathrm{Ca}^{2+}$ intracelular em resposta às drogas utilizadas para estimulação. Observa-se que no grupo EX, a S6c provocou aumento de $\mathrm{Ca}^{2+}$ intracelular com amplitudes significativamente maiores que no grupo C. C: grupo controle; EX: grupo exercício; ET: endothelina; S6c: sarafotoxina $\left.6 c .{ }^{\star * \star} p<0,001\right)$. 
A

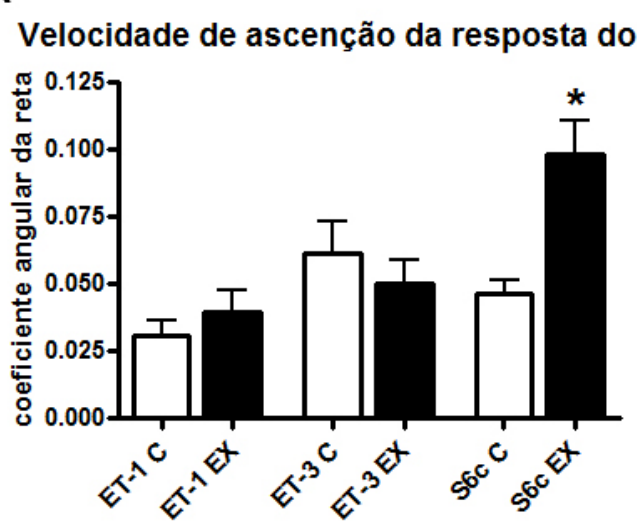

B

Área sob a curva do início da resposta-2min

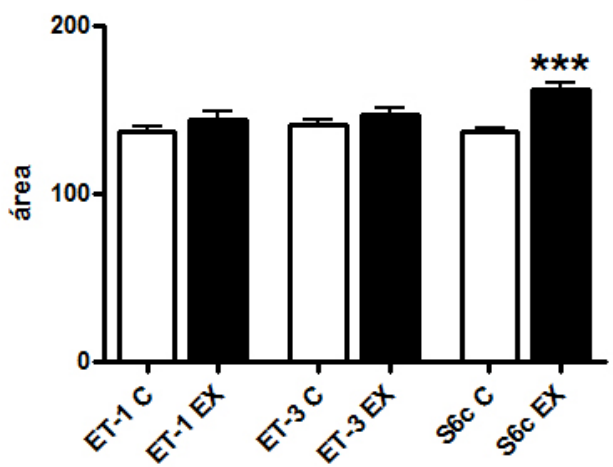

Figura 3-9. Análise cinética das respostas do C intracelular. (A) Gráfico representando a inclinação da ascenção da curva da resposta do $\mathrm{Ca}^{2+}$. Observa-se que os níveis de $\mathrm{Ca}^{2+}$ subiram de forma significativamente mais rápida em resposta à $S 6 c$ no grupo $E X\left({ }^{*} p<0,05\right)$. (B) Gráfico representando a área sob as curvas das respostas do $\mathrm{Ca}^{2+}$ do momento em que se inicia a resposta até 2 minutos após o início da resposta. Observa-se que as áreas das respostas à S6c no grupo EX foram significativamente maiores que no grupo C. C: grupo controle; EX: grupo exercício; ET: endothelina; S6c: sarafotoxina 6c. $\left({ }^{* * *} \mathrm{p}<0,001\right)$.
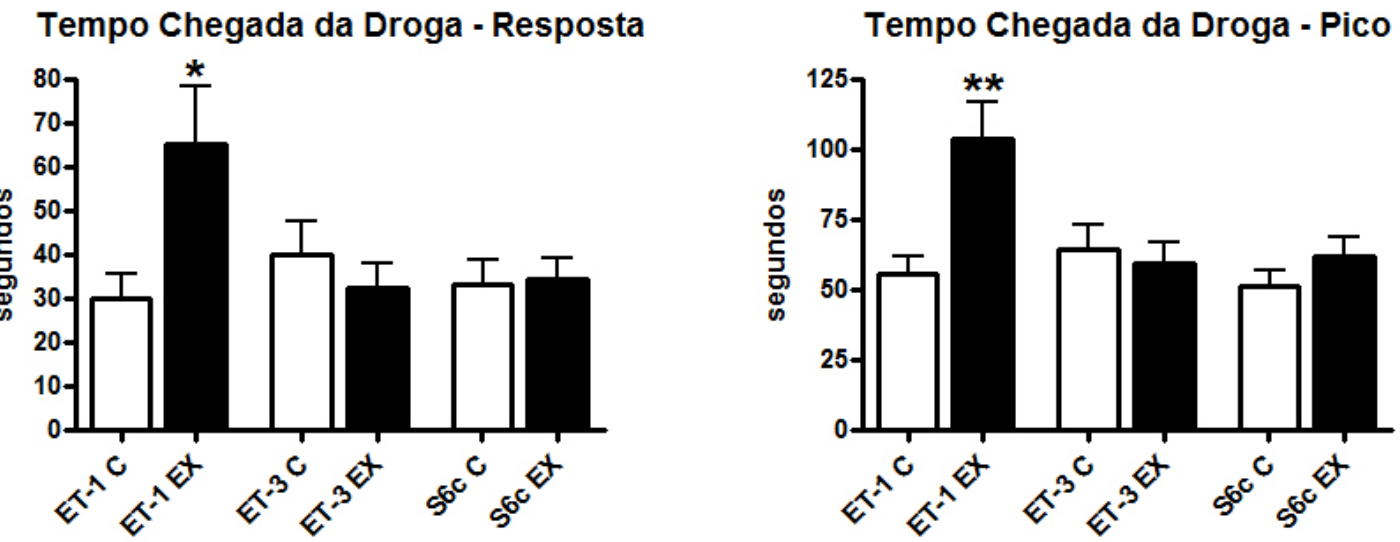

Figura 3-10. Análise temporal dos eventos de $\mathrm{Ca}^{2+}$ intracelular tomando como referência os momentos em que a droga atingiu a câmara, o momento em que a célula inicia a resposta e o momento em que ocorre o pico da resposta do $\mathrm{Ca}^{2+}$. Observa-se que as células do grupo EX responderam de forma mais tardia à ET-1. C: grupo controle; EX: grupo exercício; ET: endothelina; S6c: sarafotoxina 6c. $\left({ }^{*} p<0,05 ;{ }^{* \star} p<0,01\right)$.

\subsubsection{IMUNOFLUORESCÊNCIA}

A análise da densidade vascular e de processos astrocíticos das camadas corticais I e II (Fig.3-11) revelou aumento na densidade de processos astrocíticos na camada cortical II do grupo que realizou exercício $(p<0,05)$ (Fig.3-12), porém não foi 
observada qualquer diferença na densidade vascular destas camadas entre os dois grupos (Fig.3-13). Para a avaliação da colocalização do $\mathrm{ET}_{\mathrm{B}} \mathrm{R}$ com vasos (Isolectin 488) e astrócitos (GFAP+S100ß) (Fig.3-14) foi realizada uma análise subjetiva da distribuição deste receptor nas duas estruturas, porém não foi possível observar diferenças entre os grupos.

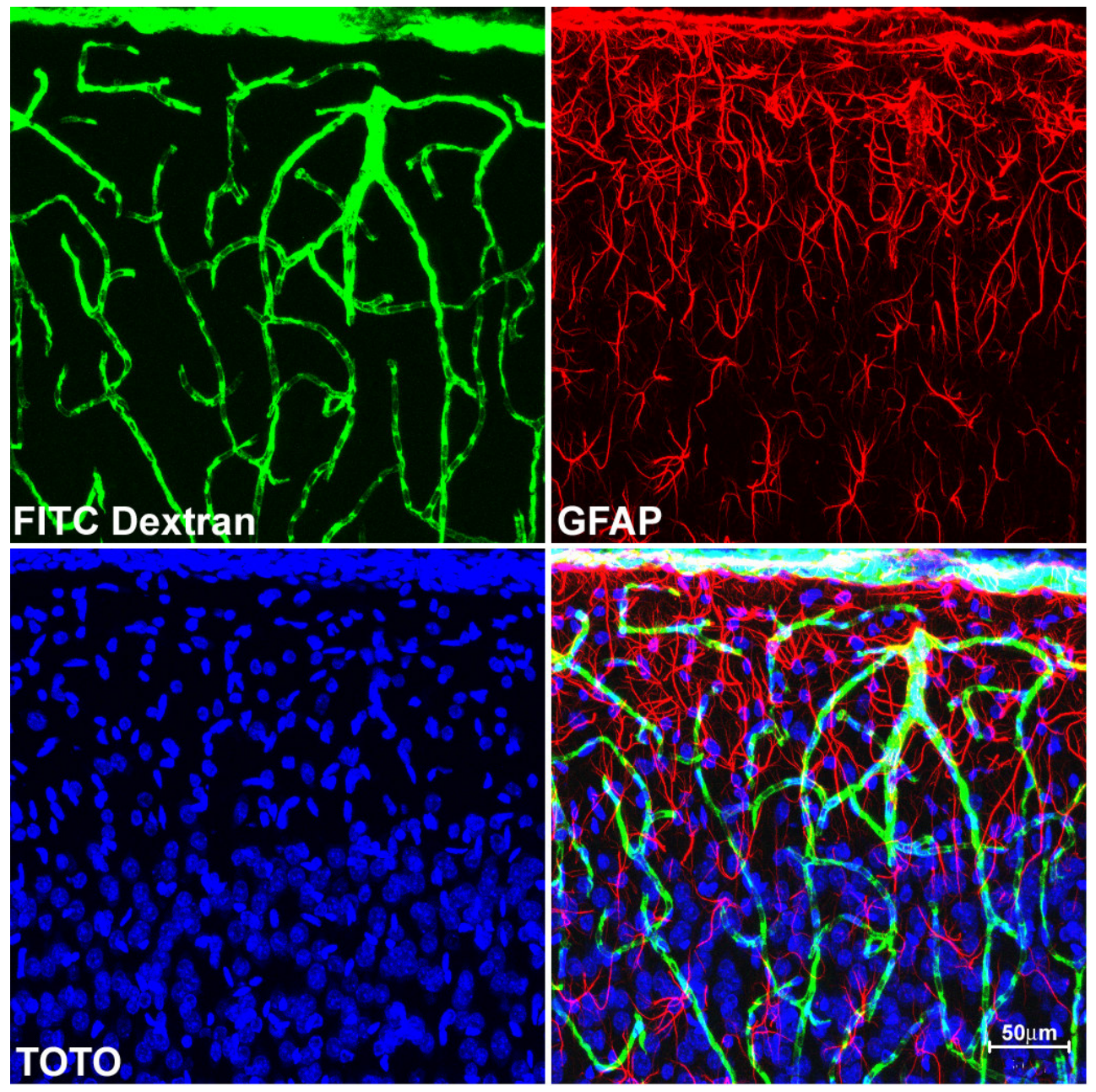

Figura 3-11. Z-Stack de $50 \mu \mathrm{m}$ (intervalo de $1 \mu \mathrm{m}$ ) das camadas corticais I e II. FITC Dextran (verde), GFAP (vermelho) e TOTO (azul) seguidos da projeção dos três canais. 


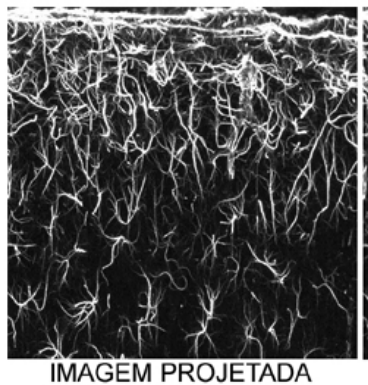

IMAGEM PROJETADA

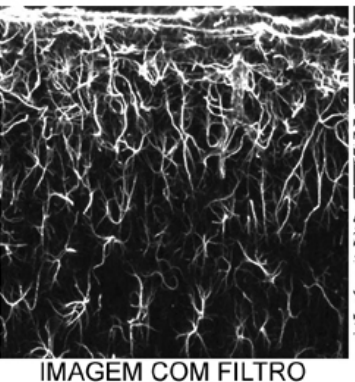

IMAGEM COM FILTRO

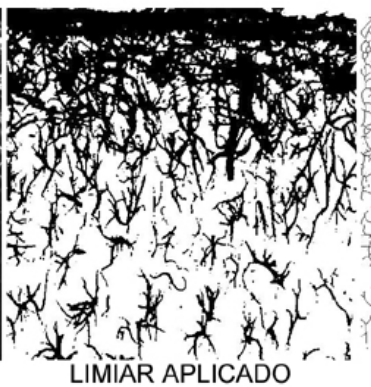

DENSIDADE GFAP

CAMADA II

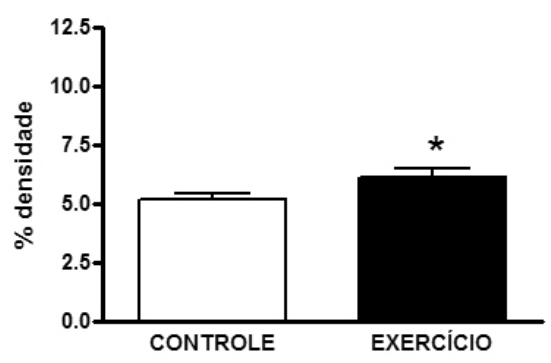

Figura 3-12. Análise da densidade de processos astrocíticos utilizando o programa Image $\mathrm{J}$ e gráficos representando as densidades obtidas para as camadas corticais I e II. Foi observado um aumento na densidade de GFAP na camada cortical II $(p<0,05)$.

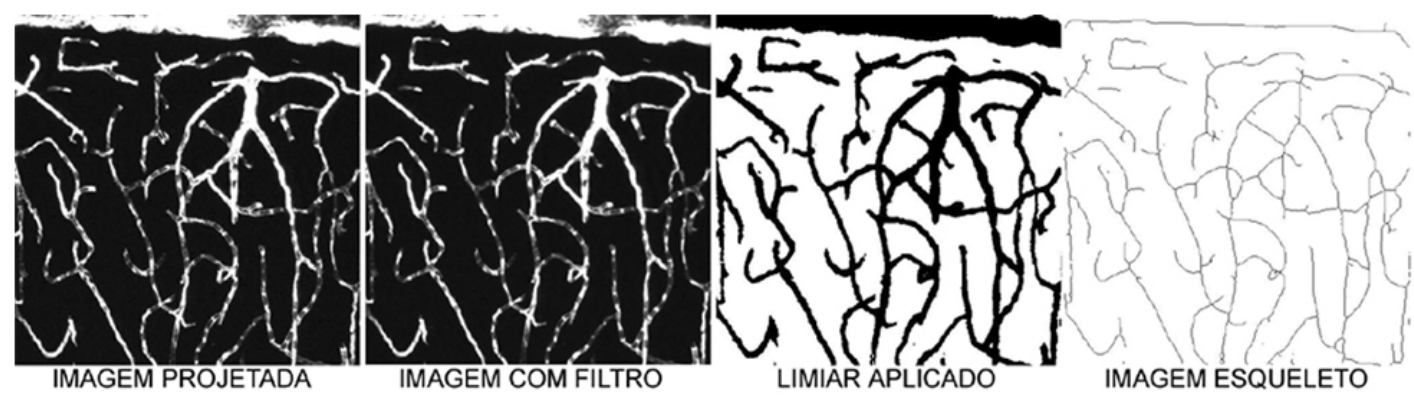

DENSIDADE VASCULAR CAMADA I

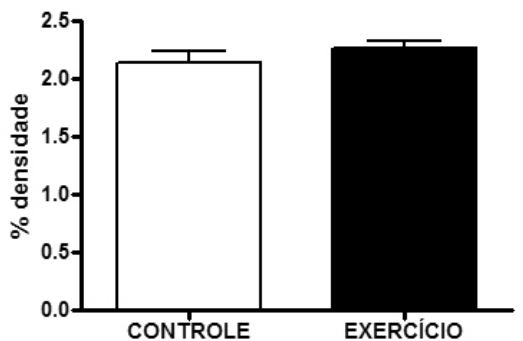

DENSIDADE VASCULAR CAMADA II

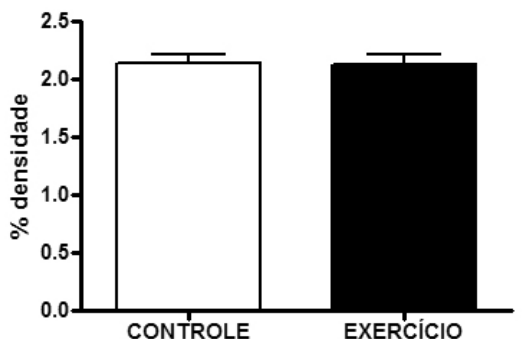

Figura 3-13. Análise da densidade vascular utilizando 0 programa Image $\mathrm{J}$ e gráficos representando as densidades obtidas para as camadas corticais I e II. Não foram observadas diferenças significativas entre os grupos. 

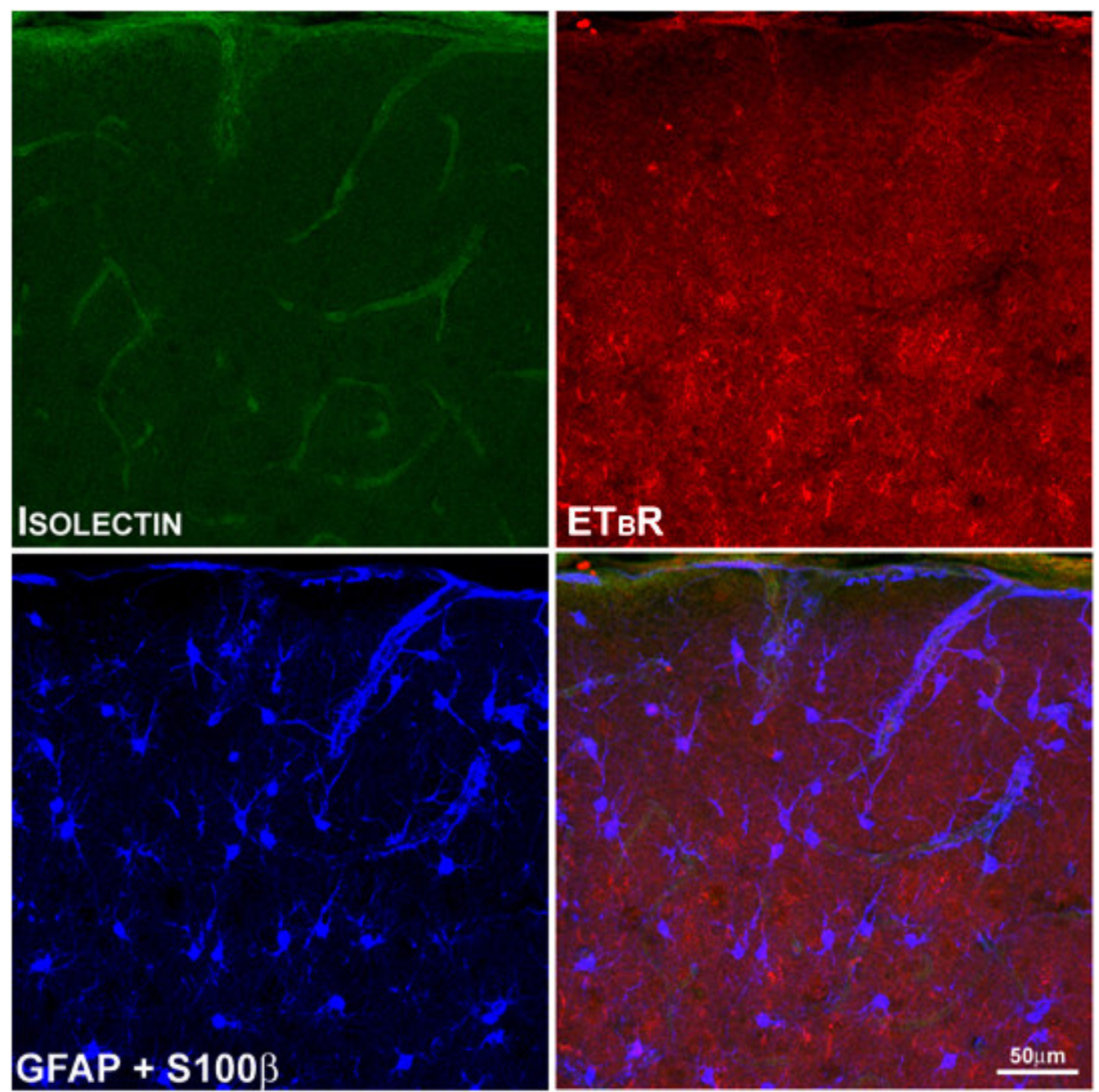

Figura 3-14. Z-Stack de $30 \mu \mathrm{m}$ (intervalo de $1 \mu \mathrm{m}$ ) das camadas corticais I e II. Isolectin (verde), $\mathrm{ET}_{\mathrm{B}} \mathrm{R}$ (vermelho) e GFAP+S100ß (azul) seguidos da projeção dos três canais.

\subsubsection{WESTERN BLOTTING}

Foram analisadas a expressão de $\mathrm{ET}_{\mathrm{B}} \mathrm{R}$ e GFAP no córtex de ratos que realizaram 2 semanas de exercício, porém não foram observadas diferenças significativas (Fig.3-15). 

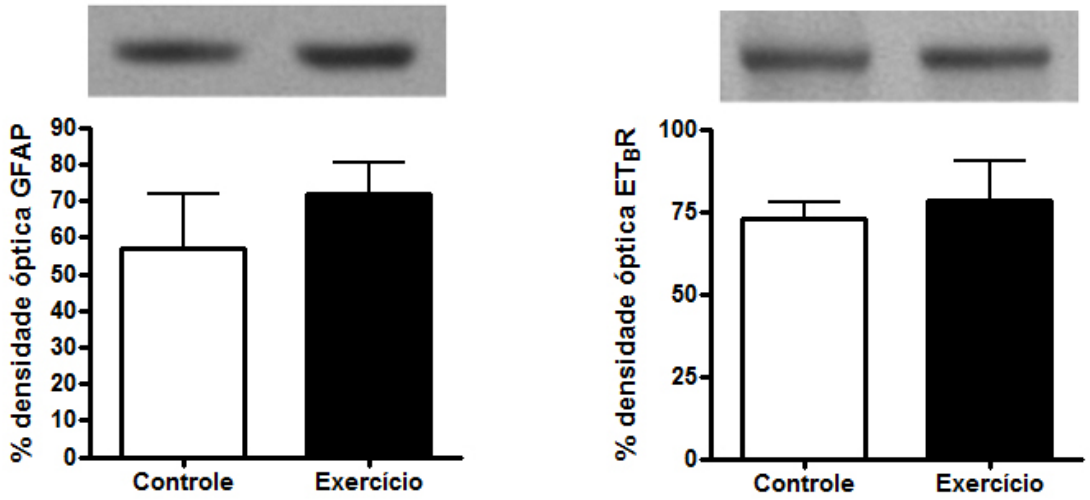

Figura 3-15. Expressão de GFAP e de $\mathrm{ET}_{\mathrm{B}} \mathrm{R}$ no córtex de ratos do grupo que realizou exercício por 2 semanas. Os gráficos representam a média da razão entre a densidade óptica das bandas das proteínas de interesse e da $\beta$-actina. Os dados estão normalizados pelos respectivos grupos sedentários e as bandas ilustradas são exemplos típicos de cada grupo. Não foi observada diferença significativa. GFAP: proteína glial fibrilar ácida; $\mathrm{ET}_{\mathrm{B}} \mathrm{R}$ : receptor de endotelina tipo $\mathrm{B}$.

\subsection{DISCUSSÃO}

\section{EFEITOS DO EXERCÍCIO NA UNIDADE NEUROVASCULAR DO ENCÉFALO DE}

\section{RATOS}

Nossos resultados demonstram que o exercício físico moderado de curta duração induziu a potencialização da resposta dos astrócitos à S6c quanto ao pico máximo das respostas de $\mathrm{Ca}^{2+}$, à velocidade de ascenção da resposta e à magnitude e sustentação do aumento intracelular de $\mathrm{Ca}^{2+}$. Acreditando-se que o $\mathrm{ET}_{\mathrm{B}} \mathrm{R}$ é responsável pelo influxo rápido de $\mathrm{Ca}^{2+}$ nos astrócitos (Ehrenreich et al., 1999), pode-se concluir que a potencialização da resposta do agonista seletivo deste receptor quanto à amplitude da resposta e à velocidade da resposta a atingir seu pico são indícios da maior sensibilidade ou maior expressão deste receptor nos astrócitos após o protocolo de exercício. Pôde-se observar também um retardo da resposta dos astrócitos à ET-1. Uma vez que este peptídio age preferencialmente sobre o $E T_{A} R$, promovendo vasoconstrição (Blomstrand et al., 1999), pode-se concluir que o exercício possivelmente promoveu uma inibição desta via, corroborando com os diversos achados que mostram os efeitos benéficos do exercício em casos de hipertensão (Dishman et al., 2006). 
Foi observado também um aumento da densidade do marcador GFAP na camada cortical II. Pode-se especular que o aumento na densidade de processos astrocíticos na ausência de um aumento da densidade vascular indica que os astrócitos podem atuar como precursores, guiando de certa forma a possível angiogênese decorrente do exercício físico.

Para identificação de uma possível alteração no padrão de distribuição do $E T_{B} R$ entre os vasos e os astrócitos e da expressão deste receptor no córtex, realizamos experimentos de imunofluorescência com tripla marcação e Western blotting. Nossa análise subjetiva não detectou alterações na distribuição deste receptor entre vasos e astrócitos e nos ensaios de Western blotting para análise da expressão de $\mathrm{ET}_{\mathrm{B}} \mathrm{R}$ no córtex também não foi observada diferença significativa. Os achados de Western blotting podem ser explicados devido ao fato de haver expressão deste receptor em concentrações variadas nas duas diferentes estruturas da unidade neurovascular. Por exemplo, foi observado que em algumas situações ocorre a redução da expressão do $\mathrm{ET}_{\mathrm{B}} \mathrm{R}$ no endotélio e o aumento da expressão do $E T_{B} R$ nos astrócitos (Ehrenreich, 1999; Sirén et al., 2000). Outra possível explicação seria baseada no aumento da sensibilidade do receptor causar a potenciação das respostas, e não o aumento da expressão deste. Além da análise da expressão de $E T_{B} R$, analisamos a expressão de GFAP no córtex de animais controle e exercitados, porém não observamos diferença significativa. Uma vez que observamos aumento da densidade de processos astrocíticos, a manutenção dos níveis protéicos pode ter ocorrido devido ao fato de que neste protocolo de exercício ocorreu apenas um remodelamento discreto dos processos dos astrócitos, não suficiente para alterar os níveis expressos em todas as camadas corticais.

Diante dos resultados obtidos até o momento, pode-se concluir que o exercício físico de intensidade moderada e de curta duração foi suficiente para induzir alterações plásticas nos astrócitos e discretas alterações estruturais, apesar de não ter alterado o nível de expressão de GFAP nem de $E_{B} R$. Conhecendo as funções dos astrócitos em mecanismos como a regulação da homeostase de água e $\mathrm{K}^{+}$, modulação da atividade neuronal e regulação do tônus vascular, acreditamos que o esclarecimento dos efeitos do exercício sobre os astrócitos é de fundamental importância. 


\section{* CAPÍTULO 4}

\section{CONCLUSÕES GERAIS}

Com base nos resultados obtidos neste trabalho, pode-se concluir que 0 exercício de curta duração e intensidade moderada abaixo do limiar de lactato é capaz de promover mudanças plásticas, como o aumento da quantidade de proteínas de vesícula e alterações de elementos estruturais de neurônios e astrócitos em diversas regiões do encéfalo de ratos, aumento da neurogênese hipocampal adulta, e alteração da sinalização dos astrócitos. Alterações nos níveis moleculares mudam a eficiência sináptica e seletividade para sinais, enquanto que alterações nos níveis celulares e de circuitos podem alterar e reparar estruturas no sistema nervoso (Azizi e Vendrame, 2007). Estes resultados podem contribuir para um melhor planejamento de protocolos de exercícios para pessoas incapazes de tolerar atividades físicas vigorosas, permitindo que estas obtenham benefícios com atividades mais adequadas para a sua condição. Além disso, pode-se considerar o exercício como uma abordagem terapêutica potencialmente eficaz em casos de disfunções de diversas áreas do sistema nervoso e que este estímulo promove alterações difusas, podendo levar a uma plasticidade robusta e um encéfalo mais saudável. 


\section{REFERÊNCIAS*}

Alberts B, Johnson A, Lewis J, Raff M, Roberts K, Walter P. Molecular Biology of the Cell. 4th ed. New York: Garland Publishing; 2002.

Allen NJ, Barres BA. Neuroscience: Glia - more than just brain glue. Nature. 2009; 457:675-7.

American College of Sports Medicine. Guidelines for exercise testing and prescription. 5th ed. Philadelphia: Lippincott Williams \& Wilkins; 2000.

Andersen P, Morris R, Amaral D, Bliss T,O'Keefe J. The Hippocampus Book. New York: Oxford University Press; 2007.

Anderson CM, Nedergaard M. Astrocyte-mediated control of cerebral microcirculation. Trends Neurosci. 2003;26:340-4.

Andersson U, Treebak JT, Nielsen JN, Smith KL, Abbott CR, Small CJ, Carling D, Richter EA. Exercise in rats does not alter hypothalamic AMP-activated protein kinase activity. Biochem Biophys Res Commun. 2005;329:719-25.

Angeles Fernandez-Gil M, Palacios-Bote R, Leo-Barahona M, Mora-Encinas JP. Anatomy of the brainstem: a gaze into the stem of life. Semin Ultrasound CT MR. 2010;31:196-219.

Araque A, Carmignoto G, Haydon PG. Dynamic signaling between astrocytes and neurons. Annu Rev Physiol. 2001;63:795-813.

Arida RM, Sanabria ER, da Silva AC, Faria LC, Scorza FA, Cavalheiro EA. Physical training reverts hippocampal electrophysiological changes in rats submitted to the pilocarpine model of epilepsy. Physiol Behav. 2004a;83:165-71.

Arida RM, Scorza CA, da Silva AV, Scorza FA, Cavalheiro EA. Differential effects of spontaneous versus forced exercise in rats on the staining of parvalbumin-positive neurons in the hippocampal formation. Neurosci Lett. 2004b;364:135-8. 
Arida RM, Scorza CA, Scorza FA, Gomes da Silva S, da Graca Naffah-Mazzacoratti $M$, Cavalheiro EA. Effects of different types of physical exercise on the staining of parvalbumin-positive neurons in the hippocampal formation of rats with epilepsy. Prog Neuropsychopharmacol Biol Psychiatry. 2007;31:814-22.

Armstrong DM, Marple-Horvat DE. Role of the cerebellum and motor cortex in the regulation of visually controlled locomotion. Can J Physiol Pharmacol. 1996;74:44355.

Artola A, von Frijtag JC, Fermont PC, Gispen WH, Schrama LH, Kamal A, Spruijt BM. Long-lasting modulation of the induction of LTD and LTP in rat hippocampal CA1 by behavioural stress and environmental enrichment. Eur J Neurosci. 2006;23:261-72.

Azizi SA, Vendrame M. Exercise: a workout for neuroregeneration. Neurosci Lett. 2007;418:211-2.

Barton M, Yanagisawa M. Endothelin: 20 years from discovery to therapy. Can J Physiol Pharmacol. 2008;86:485-98.

Bear MF, Connors BW, Paradiso MA. Neurociências: Desvendando o Sistema Nervoso. 2. ed. Porto Alegre: Artmed; 2002.

Berchtold NC, Chinn G, Chou M, Kesslak JP, Cotman CW. Exercise primes a molecular memory for brain-derived neurotrophic factor protein induction in the rat hippocampus. Neuroscience. 2005;133:853-61.

Berchtold NC, Kesslak JP, Cotman CW. Hippocampal brain-derived neurotrophic factor gene regulation by exercise and the medial septum. J Neurosci Res. 2002; 68:511-21.

Blomstrand F, Giaume C, Hansson E, Ronnback L. Distinct pharmacological properties of ET-1 and ET-3 on astroglial gap junctions and $\mathrm{Ca}(2+)$ signaling. $\mathrm{Am} \mathrm{J}$ Physiol. 1999;277:C616-27.

Bonnefoi-Kyriacou B, Legallet E, Lee RG, Trouche E. Spatio-temporal and kinematic analysis of pointing movements performed by cerebellar patients with limb ataxia. Exp Brain Res. 1998;119:460-6. 
Bradford MM. A rapid and sensitive method for the quantitation of microgram quantities of protein utilizing the principle of protein-dye binding. Anal Biochem. 1976; 72:248-54.

Brock TO, O'Callaghan JP. Quantitative changes in the synaptic vesicle proteins synapsin I and p38 and the astrocyte-specific protein glial fibrillary acidic protein are associated with chemical-induced injury to the rat central nervous system. J Neurosci. 1987;7:931-42.

Brodal A. Neurological Anatomy. In relation to Clinical Medicine. 3rd ed. New York: Oxford University Press; 1981.

Cabalka LM, Hyman BT, Goodlett CR, Ritchie TC, Van Hoesen GW. Alteration in the pattern of nerve terminal protein immunoreactivity in the perforant pathway in Alzheimer's disease and in rats after entorhinal lesions. Neurobiol Aging. 1992; 13:283-91.

Campbell K, Gotz M. Radial glia: multi-purpose cells for vertebrate brain development. Trends Neurosci. 2002; 25:235-8.

Carro E, Trejo JL, Busiguina S, Torres-Aleman I. Circulating insulin-like growth factor I mediates the protective effects of physical exercise against brain insults of different etiology and anatomy. J Neurosci. 2001; 21:5678-84.

Cavaglia M, Dombrowski SM, Drazba J, Vasanji A, Bokesch PM, Janigro D. Regional variation in brain capillary density and vascular response to ischemia. Brain Res. 2001; 910:81-93.

Cechetti F, Fochesatto C, Scopel D, Nardin P, Goncalves CA, Netto CA, Siqueira IR. Effect of a neuroprotective exercise protocol on oxidative state and BDNF levels in the rat hippocampus. Brain Res. 2008; 1188:182-8.

Cechetti F, Rhod A, Simao F, Santin K, Salbego C, Netto CA, Siqueira IR. Effect of treadmill exercise on cell damage in rat hippocampal slices submitted to oxygen and glucose deprivation. Brain Res. 2007; 1157:121-5.

Centers for Disease Control and Prevention. Prevalence of physical activity, including lifestyle activities among adults - United States, 2000-2001. Morb Mort Weekly Report. 2003; 52:764-769. 
Cereseto M, Reines A, Ferrero A, Sifonios L, Rubio M, Wikinski S. Chronic treatment with high doses of corticosterone decreases cytoskeletal proteins in the rat hippocampus. Eur J Neurosci. 2006; 24:3354-64.

Chang HC, Yang YR, Wang SG, Wang RY. Effects of treadmill training on motor performance and extracellular glutamate level in striatum in rats with or without transient middle cerebral artery occlusion. Behav Brain Res. 2009; 205:450-5.

Chen $\mathrm{H}$, Zhang SM, Schwarzschild MA, Hernan MA, Ascherio A. Physical activity and the risk of Parkinson disease. Neurology. 2005; 64:664-9.

Chen WQ, Viidik A, Skalicky M, Hoger H, Lubec G. Hippocampal signaling cascades are modulated in voluntary and treadmill exercise rats. Electrophoresis. 2007; 28:4392-400.

Chin LS, Li L, Ferreira A, Kosik KS, Greengard P. Impairment of axonal development and of synaptogenesis in hippocampal neurons of synapsin I-deficient mice. Proc Natl Acad Sci U S A. 1995; 92:9230-4.

Chiodera P, Volpi R, Maffei ML, Caiazza A, Caffarri G, Papadia C, Alfano F, Capretti $L$, Pagani D, Coiro V. Role of GABA and opioids in the regulation of the vasopressin response to physical exercise in normal men. Regul Pept. 1993; 49:57-63.

Christie BR, Swann SE, Fox CJ, Froc D, Lieblich SE, Redila V, Webber A. Voluntary exercise rescues deficits in spatial memory and long-term potentiation in prenatal ethanol-exposed male rats. Eur J Neurosci. 2005; 21:1719-26.

Chu CJ, Jones TA. Experience-dependent structural plasticity in cortex heterotopic to focal sensorimotor cortical damage. Exp Neurol. 2000; 166:403-14.

Cohen AD, Tillerson JL, Smith AD, Schallert T, Zigmond MJ. Neuroprotective effects of prior limb use in 6-hydroxydopamine-treated rats: possible role of GDNF. J Neurochem. 2003; 85:299-305.

Cohen Z, Bonvento G, Lacombe P, Hamel E. Serotonin in the regulation of brain microcirculation. Prog Neurobiol. 1996; 50:335-362.

Cosi C, Spoerri PE, Comelli MC, Guidolin D, Skaper SD. Glucocorticoids depress activity-dependent expression of BDNF mRNA in hippocampal neurones. Neuroreport. 1993; 4:527-30. 
Cotman CW, Berchtold NC. Exercise: a behavioral intervention to enhance brain health and plasticity. Trends Neurosci. 2002; 25:295-301.

Cotman CW. Axon Sprouting and Regeneration. In: Siegal GJ, Agranoff BW, Albers RW, Fisher SK, Uhler MD (editors). Basic Neurochemistry: Molecular, Cellular and Medical Aspects. 6th ed. Philadelphia: Lippincott, Williams \& Wilkins; 1999.

Cowen DS. Serotonin and neuronal growth factors - a convergence of signaling pathways. J Neurochem. 2007; 101:1161-71.

Dahm R, Kiebler M,Macchi P. RNA localisation in the nervous system. Semin Cell Dev Biol. 2007; 18:216-23.

Daly C, Sugimori M, Moreira JE, Ziff EB, Llinas R. Synaptophysin regulates clathrinindependent endocytosis of synaptic vesicles. Proc Natl Acad Sci U S A. 2000; 97:6120-5.

Deng W, Aimone JB, Gage FH. New neurons and new memories: how does adult hippocampal neurogenesis affect learning and memory? Nat Rev Neurosci. 2010; 11:339-50.

Denio LS, Drake ME, Jr., Pakalnis A. The effect of exercise on seizure frequency. J Med. 1989; 20:171-6.

Depreter M, Vandesompele J, Espeel M, Speleman F, Roels F. Modulation of the peroxisomal gene expression pattern by dehydroepiandrosterone and vitamin D: therapeutic implications. J Endocrinol. 2002; 175:779-92.

Deschenes MR, Maresh CM, Crivello JF, Armstrong LE, Kraemer WJ, Covault J. The effects of exercise training of different intensities on neuromuscular junction morphology. J Neurocytol. 1993; 22:603-15.

Di Stefano G, Casoli T, Fattoretti P, Balietti M, Grossi Y, Giorgetti B, Bertoni-Freddari C. Level and distribution of microtubule-associated protein-2 (MAP2) as an index of dendritic structural dynamics. Rejuvenation Res. 2006; 9:94-8. 
Di Stefano G, Casoli T, Fattoretti P, Gracciotti N, Solazzi M, Bertoni-Freddari C. Distribution of map2 in hippocampus and cerebellum of young and old rats by quantitative immunohistochemistry. J Histochem Cytochem. 2001; 49:1065-6.

Ding Q, Vaynman S, Akhavan M, Ying Z, Gomez-Pinilla F. Insulin-like growth factor I interfaces with brain-derived neurotrophic factor-mediated synaptic plasticity to modulate aspects of exercise-induced cognitive function. Neuroscience. 2006a; 140:823-33.

Ding Q, Vaynman S, Souda P, Whitelegge JP, Gomez-Pinilla F. Exercise affects energy metabolism and neural plasticity-related proteins in the hippocampus as revealed by proteomic analysis. Eur J Neurosci. 2006b; 24:1265-76.

Ding Y, Li J, Lai Q, Azam S, Rafols JA, Diaz FG. Functional improvement after motor training is correlated with synaptic plasticity in rat thalamus. Neurol Res. 2002; 24:829-36.

Ding Y, Li J, Luan X, Ding YH, Lai Q, Rafols JA, Phillis JW, Clark JC, Diaz FG. Exercise pre-conditioning reduces brain damage in ischemic rats that may be associated with regional angiogenesis and cellular overexpression of neurotrophin. Neuroscience. 2004; 124:583-91.

Dishman RK, Berthoud HR, Booth FW, Cotman CW, Edgerton VR, Fleshner MR, Gandevia SC, Gomez-Pinilla F, Greenwood BN, Hillman CH, Kramer AF, Levin BE, Moran TH, Russo-Neustadt AA, Salamone JD, Van Hoomissen JD, Wade CE, York DA,Zigmond MJ. Neurobiology of exercise. Obesity (Silver Spring). 2006;14:345-56.

Dishman RK. Brain monoamines, exercise, and behavioral stress: animal models. Med Sci Sports Exerc. 1997;29:63-74.

Doetsch F, Caille I, Lim DA, Garcia-Verdugo JM, Alvarez-Buylla A. Subventricular zone astrocytes are neural stem cells in the adult mammalian brain. Cell. 1999; 97:703-16.

Doyon J, Bellec P, Amsel R, Penhune V, Monchi O, Carrier J, Lehericy S, Benali H. Contributions of the basal ganglia and functionally related brain structures to motor learning. Behav Brain Res. 2009;199:61-75.

Dustman RE, Emmerson RY, Ruhling RO, Shearer DE, Steinhaus LA, Johnson SC, Bonekat HW, Shigeoka JW. Age and fitness effects on EEG, ERPs, visual sensitivity, and cognition. Neurobiol Aging. 1990;11:193-200. 
Eadie BD, Redila VA, Christie BR. Voluntary exercise alters the cytoarchitecture of the adult dentate gyrus by increasing cellular proliferation, dendritic complexity, and spine density. J Comp Neurol. 2005;486:39-47.

Edgerton VR, Tillakaratne NJ, Bigbee AJ, de Leon RD, Roy RR. Plasticity of the spinal neural circuitry after injury. Annu Rev Neurosci. 2004; 27:145-67.

Ehninger D, Kempermann G. Regional effects of wheel running and environmental enrichment on cell genesis and microglia proliferation in the adult murine neocortex. Cereb Cortex. 2003;13:845-51.

Ehrenreich H, Oldenburg J, Hasselblatt M, Herms J, Dembowski C, Loffler BM, Bruck W, Kamrowski-Kruck H, Gall S, Siren AL, Schilling L. Endothelin B receptor-deficient rats as a subtraction model to study the cerebral endothelin system. Neuroscience. 1999; 91:1067-75.

Ehrenreich $\mathrm{H}$. The astrocytic endothelin system: toward solving a mystery focus on "distinct pharmacological properties of ET-1 and ET-3 on astroglial gap junctions and Ca(2+) signaling". Am J Physiol. 1999;277:C614-5.

Elmariah SB, Hughes EG, Oh EJ, Balice-Gordon RJ. Neurotrophin signaling among neurons and glia during formation of tripartite synapses. Neuron Glia Biol. 2005;1:111.

Eng LF, Vanderhaeghen JJ, Bignami A, Gerstl B. An acidic protein isolated from fibrous astrocytes. Brain Res. 1971;28:351-4.

Eriksen HR, Ellertsen B, Gronningsaeter H, Nakken KO, Loyning Y, Ursin H. Physical exercise in women with intractable epilepsy. Epilepsia. 1994;35:1256-64.

Evans GJ, Cousin MA. Tyrosine phosphorylation of synaptophysin in synaptic vesicle recycling. Biochem Soc Trans. 2005;33:1350-3.

Fabel K, Tam B, Kaufer D, Baiker A, Simmons N, Kuo CJ,Palmer TD. VEGF is necessary for exercise-induced adult hippocampal neurogenesis. Eur J Neurosci. 2003; 8:2803-12. 
Fabel K, Kempermann G. Physical activity and the regulation of neurogenesis in the adult and aging brain. Neuromolecular Med. 2008;10:59-66.

Fanara $\mathrm{P}$, Husted $\mathrm{KH}$, Selle K, Wong PY, Banerjee J, Brandt R, Hellerstein MK. Changes in microtubule turnover accompany synaptic plasticity and memory formation in response to contextual fear conditioning in mice. Neuroscience. 2010; 168:167-78.

Farmer J, Zhao X, van Praag H, Wodtke K, Gage FH, Christie BR. Effects of voluntary exercise on synaptic plasticity and gene expression in the dentate gyrus of adult male Sprague-Dawley rats in vivo. Neuroscience. 2004;124:71-9.

Farrell PA, Garthwaite TL, Gustafson AB. Plasma adrenocorticotropin and cortisol responses to submaximal and exhaustive exercise. J Appl Physiol. 1983;55:1441-4.

Felix JV, Michelini LC. Training-induced pressure fall in spontaneously hypertensive rats is associated with reduced angiotensinogen mRNA expression within the nucleus tractus solitarii. Hypertension. 2007;50:780-5.

Ferreira AF, Real CC, Rodrigues AC, Alves AS, Britto LR. Moderate exercise changes synaptic and cytoskeletal proteins in motor regions of the rat brain. Brain Res. 2010;1361:31-42.

Filosa JA, Bonev AD, Straub SV, Meredith AL, Wilkerson MK, Aldrich RW, Nelson MT. Local potassium signaling couples neuronal activity to vasodilation in the brain. Nat Neurosci. 2006;9:1397-1403.

Filosa JA, Bonev AD, Nelson MT. Calcium dynamics in cortical astrocytes and arterioles during neurovascular coupling. Circ Res. 2004;95:e73-81.

Fisher BE, Wu AD, Salem GJ, Song J, Lin CH, Yip J, Cen S, Gordon J, Jakowec M, Petzinger $G$. The effect of exercise training in improving motor performance and corticomotor excitability in people with early Parkinson's disease. Arch Phys Med Rehabil. 2008;89:1221-9.

Folsom AR, Kushi LH, Hong CP. Physical activity and incident diabetes mellitus in postmenopausal women. Am J Public Health. 2000;90:134-8. 
Fordyce DE, Wehner JM. Physical activity enhances spatial learning performance with an associated alteration in hippocampal protein kinase $\mathrm{C}$ activity in C57BL/6 and DBA/2 mice. Brain Res. 1993;619:111-9.

Freund TF, Buzsaki G. Interneurons of the hippocampus. Hippocampus. 1996; 6:347-470.

Galbo H. Exercise Physiology: humoral function. Sport Sci. Rev. 1992;1:65-93.

Garner CC, Tucker RP,Matus A. Selective localization of messenger RNA for cytoskeletal protein MAP2 in dendrites. Nature. 1988;336:674-7.

Gebauer F, Hentze MW. Molecular mechanisms of translational control. Nat Rev Mol Cell Biol. 2004;5:827-35.

Gentile AM, Beheshti Z, Held JM. Enrichment versus exercise effects on motor impairments following cortical removals in rats. Behav Neural Biol. 1987;47:321-32.

Girardi AC, Rocha RO, Britto LR, Reboucas NA. Upregulation of NHE3 is associated with compensatory cell growth response in young uninephrectomized rats. Am J Physiol Renal Physiol. 2002;283:F1296-303.

Goldshmit Y, Lythgo N, Galea MP, Turnley AM. Treadmill training after spinal cord hemisection in mice promotes axonal sprouting and synapse formation and improves motor recovery. J Neurotrauma. 2008;25:449-65.

Gomez-Pinilla F, Dao L, So V. Physical exercise induces FGF-2 and its mRNA in the hippocampus. Brain Res. 1997;764:1-8.

Gomez-Pinilla F, Ying Z, Roy RR, Molteni R, Edgerton VR. Voluntary exercise induces a BDNF-mediated mechanism that promotes neuroplasticity. J Neurophysiol. 2002; 88:2187-95.

Gomez-Pinilla F. Brain foods: the effects of nutrients on brain function. Nat Rev Neurosci. 2008;9:568-78.

Goto S, Hirano A. Synaptophysin expression in the striatum in Huntington's disease. Acta Neuropathol. 1990;80:88-91. 
Gotow T. Neurofilaments in health and disease. Med Electron Microsc. 2000;33:17399.

Gotze W, Kubicki S, Munter M, Teichmann J. Effect of physical exercise on seizure threshold (investigated by electroencephalographic telemetry). Dis Nerv Syst. 1967; 28:664-7.

Gould E, Cameron HA, Daniels DC, Woolley CS, McEwen BS. Adrenal hormones suppress cell division in the adult rat dentate gyrus. J Neurosci. 1992;12:3642-50.

Grace L, Hescham S, Kellaway LA, Bugarith K, Russell VA. Effect of exercise on learning and memory in a rat model of developmental stress. Metab Brain Dis. 2009; 24:643-57.

Grealy MA, Johnson DA, Rushton SK. Improving cognitive function after brain injury: the use of exercise and virtual reality. Arch Phys Med Rehabil. 1999;80:661-7.

Greenberg ME, Xu B, Lu B, Hempstead BL. New insights in the biology of BDNF synthesis and release: implications in CNS function. J Neurosci. 2009;29:12764-7.

Griesbach GS, Gomez-Pinilla F, Hovda DA. The upregulation of plasticity-related proteins following TBI is disrupted with acute voluntary exercise. Brain Res. 2004a; 1016:154-62.

Griesbach GS, Hovda DA, Molteni R, Wu A, Gomez-Pinilla F. Voluntary exercise following traumatic brain injury: brain-derived neurotrophic factor upregulation and recovery of function. Neuroscience. 2004b;125:129-39.

Gulbenkaian S, Uddman R, Edvinsson L. Neuronal messengers in the human cerebral circulation. Peptides. 2001; 22:995-1007.

Haheim LL, Holme I, Hjermann I, Leren P. Risk factors of stroke incidence and mortality. A 12-year follow-up of the Oslo Study. Stroke. 1993;24:1484-9.

Hart G. The O-GlcNAc Modification. In: Varki A, Cummings R, Esko J, Freeze H, Hart G, Marth J (editors). Essencials of Glycobiology. Plainview: Cold Spring Harbor Laboratory Press;1999. 
Haydon PG. GLIA: listening and talking to the synapse. Nat Rev Neurosci. 2001; 2:185-93.

Heinonen O, Soininen H, Sorvari H, Kosunen O, Paljarvi L, Koivisto E,Riekkinen PJ, Sr. Loss of synaptophysin-like immunoreactivity in the hippocampal formation is an early phenomenon in Alzheimer's disease. Neuroscience. 1995;64:375-84.

Higa-Taniguchi KT, Silva FC, Silva HM, Michelini LC, Stern JE. Exercise traininginduced remodeling of paraventricular nucleus (nor)adrenergic innervation in normotensive and hypertensive rats. Am J Physiol Regul Integr Comp Physiol. 2007; 292:R1717-27.

Hilfiker S, Benfenati F, Doussau F, Nairn AC, Czernik AJ, Augustine GJ, Greengard $P$. Structural domains involved in the regulation of transmitter release by synapsins. $J$ Neurosci. 2005; 25:2658-69.

Hillman $\mathrm{CH}$, Erickson $\mathrm{KI}$, Kramer AF. Be smart, exercise your heart: exercise effects on brain and cognition. Nat Rev Neurosci. 2008;9:58-65.

Himeda T, Mizuno K, Kato $\mathrm{H}$, Araki T. Effects of age on immunohistochemical changes in the mouse hippocampus. Mech Ageing Dev. 2005;126:673-7.

Holmes MM, Galea LA, Mistlberger RE, Kempermann G. Adult hippocampal neurogenesis and voluntary running activity: circadian and dose-dependent effects. $J$ Neurosci Res. 2004;76:216-22.

Holschneider DP, Maarek JM, Yang J, Harimoto J, Scremin OU. Functional brain mapping in freely moving rats during treadmill walking. J Cereb Blood Flow Metab. 2003;23:925-32.

Holschneider DP, Yang J, Guo Y, Maarek JM. Reorganization of functional brain maps after exercise training: Importance of cerebellar-thalamic-cortical pathway. Brain Res. 2007;1184:96-107.

Holschneider DP, Maarek JM. Brain maps on the go: functional imaging during motor challenge in animals. Methods. 2008;45:255-61.

Hori T, Fukuda M, Suzuki H, Yano S, Ono T. SART stress effects on lymphocytes in the thymus and spleen of normal, adrenalectomized, and sympathectomized mice. Clin Immunol Immunopathol. 1993;68:243-5. 
Huang Q, Timofeeva E, Richard D. Regulation of corticotropin-releasing factor and its types 1 and 2 receptors by leptin in rats subjected to treadmill running-induced stress. J Endocrinol. 2006;191:179-88.

Huh JW, Raghupathi R, Laurer HL, Helfaer MA, Saatman KE. Transient loss of microtubule-associated protein 2 immunoreactivity after moderate brain injury in mice. J Neurotrauma. 2003;20:975-84.

ladecola C. Neurogenic control of the cerebral microcirculation: is dopamine minding the strore? Nat Neurosci. 1998; 1:263-265.

Isaacs KR, Anderson BJ, Alcantara AA, Black JE, Greenough WT. Exercise and the brain: angiogenesis in the adult rat cerebellum after vigorous physical activity and motor skill learning. J Cereb Blood Flow Metab. 1992;12:110-9.

Ishide T, Hara Y, Maher TJ, Ally A. Glutamate neurotransmission and nitric oxide interaction within the ventrolateral medulla during cardiovascular responses to muscle contraction. Brain Res. 2000;874:107-15.

Ishide T, Nauli SM, Maher TJ, Ally A. Cardiovascular responses and neurotransmitter changes following blockade of nNOS within the ventrolateral medulla during static muscle contraction. Brain Res. 2003;977:80-9.

Ishide T, Preuss CV, Maher TJ, Ally A. Neurochemistry within ventrolateral medulla and cardiovascular effects during static exercise following eNOS antagonism. Neurosci Res. 2005;52:21-30.

Ito M. Long-term depression. Annu Rev Neurosci. 1989;12:85-102.

Jackson K, Silva HM, Zhang W, Michelini LC, Stern JE. Exercise training differentially affects intrinsic excitability of autonomic and neuroendocrine neurons in the hypothalamic paraventricular nucleus. J Neurophysiol. 2005;94:3211-20.

Jahn K, Zwergal A. Imaging supraspinal locomotor control in balance disorders. Restor Neurol Neurosci. 2010;28:105-14.

Jee YS, Ko IG, Sung YH, Lee JW, Kim YS, Kim SE, Kim BK, Seo JH, Shin MS, Lee $\mathrm{HH}$, Cho HJ, Kim CJ. Effects of treadmill exercise on memory and c-Fos expression 
in the hippocampus of the rats with intracerebroventricular injection of streptozotocin. Neurosci Lett. 2008;443:188-92.

Jin J, Jing H, Choi G, Oh MS, Ryu JH, Jeong JW, Huh Y, Park C. Voluntary exercise increases the new cell formation in the hippocampus of ovariectomized mice. Neurosci Lett. 2008;439:260-3.

Johansson CB, Momma S, Clarke DL, Risling M, Lendahl U, Frisen J. Identification of a neural stem cell in the adult mammalian central nervous system. Cell. 1999;96:2534.

Johnson GV, Jope RS. The role of microtubule-associated protein 2 (MAP-2) in neuronal growth, plasticity, and degeneration. J Neurosci Res. 1992;33:505-12.

Jonsdottir IH, Hoffmann P. The significance of intensity and duration of exercise on natural immunity in rats. Med Sci Sports Exerc. 2000;32:1908-12.

Jovanovic JN, Benfenati F, Siow YL, Sihra TS, Sanghera JS, Pelech SL, Greengard $P$, Czernik AJ. Neurotrophins stimulate phosphorylation of synapsin I by MAP kinase and regulate synapsin I-actin interactions. Proc Natl Acad Sci U S A. 1996;93:367983.

Jovanovic JN, Czernik AJ, Fienberg AA, Greengard P, Sihra TS. Synapsins as mediators of BDNF-enhanced neurotransmitter release. Nat Neurosci. 2000;3:323-9.

Julien JP. Neurofilament functions in health and disease. Curr Opin Neurobiol. 1999; 9:554-60.

Kajekar R, Chen CY, Mutoh T, Bonham AC. GABA(A) receptor activation at medullary sympathetic neurons contributes to postexercise hypotension. Am J Physiol Heart Circ Physiol. 2002;282:H1615-24.

Kang $\mathrm{H}$, Schuman EM. Long-lasting neurotrophin-induced enhancement of synaptic transmission in the adult hippocampus. Science. 1995;267:1658-62.

Kempermann G, Jessberger S, Steiner B, Kronenberg G. Milestones of neuronal development in the adult hippocampus. Trends Neurosci. 2004;27:447-52.

Kiernan J. Neuroanatomia Humana de Barr. 7. ed. Barueri: Manole;2003. 
Kimelberg HK. Primary astrocyte cultures--a key to astrocyte function. Cell Mol Neurobiol. 1983;3:1-16.

Kirchner L, Chen WQ, Afjehi-Sadat L, Viidik A, Skalicky M, Hoger H, Lubec G. Hippocampal metabolic proteins are modulated in voluntary and treadmill exercise rats. Exp Neurol. 2008;212:145-51.

Kitamura T, Mishina M, Sugiyama $H$. Enhancement of neurogenesis by running wheel exercises is suppressed in mice lacking NMDA receptor epsilon 1 subunit. Neurosci Res. 2003;47:55-63.

Klabunde R. Cardiovascular Physiology Concepts. Baltimore: Lippincott Williams \& Wilkins;2004.

Komitova M, Zhao LR, Gido G, Johansson BB, Eriksson P. Postischemic exercise attenuates whereas enriched environment has certain enhancing effects on lesioninduced subventricular zone activation in the adult rat. Eur $\mathrm{J}$ Neurosci. 2005; 21:2397-405.

Kozorovitskiy Y, Gross CG, Kopil C, Battaglia L, McBreen M, Stranahan AM, Gould E. Experience induces structural and biochemical changes in the adult primate brain. Proc Natl Acad Sci U S A. 2005;102:17478-82.

Kramar EA, Lin B, Lin CY, Arai AC, Gall CM, Lynch G. A novel mechanism for the facilitation of theta-induced long-term potentiation by brain-derived neurotrophic factor. J Neurosci. 2004;24:5151-61.

Kramer AF, Hahn S, Cohen NJ, Banich MT, McAuley E, Harrison CR, Chason J, Vakil E, Bardell L, Boileau RA, Colcombe A. Ageing, fitness and neurocognitive function. Nature. 1999;400:418-9.

Kramer JM, Plowey ED, Beatty JA, Little HR, Waldrop TG. Hypothalamus, hypertension, and exercise. Brain Res Bull. 2000;53:77-85.

Krimer LS, Muly EC, 3rd, Williams GV, Goldman-Rakic PS. Dopaminergic regulation of cerebral cortical microcirculation. Nat Neurosci. 1998;1:286-9. 
Kronenberg G, Bick-Sander A, Bunk E, Wolf C, Ehninger D, Kempermann G. Physical exercise prevents age-related decline in precursor cell activity in the mouse dentate gyrus. Neurobiol Aging. 2006;27:1505-13.

Kushner SA, Elgersma Y, Murphy GG, Jaarsma D, van Woerden GM, Hojjati MR, Cui Y, LeBoutillier JC, Marrone DF, Choi ES, De Zeeuw CI, Petit TL, Pozzo-Miller L, Silva AJ. Modulation of presynaptic plasticity and learning by the $\mathrm{H}$-ras/extracellular signalregulated kinase/synapsin I signaling pathway. J Neurosci. 2005;25:9721-34.

Laemmli UK. Cleavage of structural proteins during the assembly of the head of bacteriophage T4. Nature. 1970;227:680-5.

Lambert TJ, Fernandez SM, Frick KM. Different types of environmental enrichment have discrepant effects on spatial memory and synaptophysin levels in female mice. Neurobiol Learn Mem. 2005;83:206-16.

Larsen JO, Skalicky M, Viidik A. Does long-term physical exercise counteract agerelated Purkinje cell loss? A stereological study of rat cerebellum. J Comp Neurol. 2000;428:213-22.

Lau L, Huganir RL. Tyrosine Phosphorilation. In: Siegal GJ, Agranoff BW, Albers RW, Fisher SK, Uhler MD (editors). Basic Neurochemistry: Molecular, Cellular and Medical Aspects. 6th ed. Philadelphia: Lippincott, Williams \& Wilkins;1999.

Laurin D, Verreault R, Lindsay J, MacPherson K, Rockwood K. Physical activity and risk of cognitive impairment and dementia in elderly persons. Arch Neurol. 2001; 58:498-504.

Laywell ED, Rakic P, Kukekov VG, Holland EC, Steindler DA. Identification of a multipotent astrocytic stem cell in the immature and adult mouse brain. Proc Natl Acad Sci U S A. 2000;97:13883-8.

Lee TH, Jang MH, Shin MC, Lim BV, Kim YP, Kim H, Choi HH, Lee KS, Kim EH, Kim CJ. Dependence of rat hippocampal c-Fos expression on intensity and duration of exercise. Life Sci. 2003;72:1421-36.

Leggio MG, Mandolesi L, Federico F, Spirito F, Ricci B, Gelfo F, Petrosini L. Environmental enrichment promotes improved spatial abilities and enhanced dendritic growth in the rat. Behav Brain Res. 2005;163:78-90. 
Lent R. Neurociência da Mente e do Comportamento. Rio de Janeiro: Guanabara Koogan;2008.

Lewis MM, Slagle CG, Smith AB, Truong $Y$, Bai $P$, Mckeown MJ, Mailman RB, Belger $A$, Huang $X$. Task specific influences of Parkinson's disease on the striatothalamo-cortical and cerebello-thalamo-cortical motor circuitries. Neuroscience. 2007; 147:224-35.

Li B, Yamamori H, Tatebayashi Y, Shafit-Zagardo B, Tanimukai H, Chen S, Iqbal K, Grundke-lqbal I. Failure of neuronal maturation in Alzheimer disease dentate gyrus. J Neuropathol Exp Neurol. 2008;67:78-84.

Li J, Ding YH, Rafols JA, Lai Q, McAllister JP, 2nd, Ding Y. Increased astrocyte proliferation in rats after running exercise. Neurosci Lett. 2005;386:160-4.

Liang KY, Mintun MA, Fagan AM, Goate AM, Bugg JM, Holtzman DM, Morris JC, Head D. Exercise and Alzheimer's disease biomarkers in cognitively normal older adults. Ann Neurol. 2010;68:311-8.

Liepert J, Hamzei F, Weiller C. Lesion-induced and training-induced brain reorganization. Restor Neurol Neurosci. 2004;22:269-77.

Lindauer U, Megow D, Matsuda H, Dirnagl U. Nitric oxide: a modulator, but not a mediator, of neurovascular coupling in rat somatosensory cortex. Am J Physiol. 1999; 277:H799-811.

Liste I, Guerra MJ, Caruncho HJ, Labandeira-Garcia JL. Treadmill running induces striatal Fos expression via NMDA glutamate and dopamine receptors. Exp Brain Res. 1997;115:458-68.

Livingston S. Epilepsy and sports. Am Fam Physician. 1978;17:67-69.

Lo DC. Neurotrophic factors and synaptic plasticity. Neuron. 1995;15:979-81.

Lodish H, Berk A, Zipursky SL, Matsudaira P, Baltimore D, Darnell JE. Molecular Cell Biology. 4th ed. New York: W. H. Freeman \& Co.;2000.

Lou SJ, Liu JY, Chang $\mathrm{H}$, Chen PJ. Hippocampal neurogenesis and gene expression depend on exercise intensity in juvenile rats. Brain Res. 2008;1210:48-55. 
Lupinacci NS, Rikli RE, Jones CJ, Ross D. Age and physical activity effects on reaction time and digit symbol substitution performance in cognitively active adults. Res Q Exerc Sport. 1993;64:144-50.

Mabandla M, Kellaway L, St Clair Gibson A, Russell VA. Voluntary running provides neuroprotection in rats after 6-hydroxydopamine injection into the medial forebrain bundle. Metab Brain Dis. 2004;19:43-50.

Machado A. Neuroanatomia Funcional. Rio de Janeiro: Atheneu;1993.

Malatesta P, Hartfuss E, Gotz M. Isolation of radial glial cells by fluorescent-activated cell sorting reveals a neuronal lineage. Development. 2000;127:5253-63.

Manzoni D. The cerebellum and sensorimotor coupling: looking at the problem from the perspective of vestibular reflexes. Cerebellum. 2007; 6:24-37.

Marder E, Bucher D. Central pattern generators and the control of rhythmic movements. Curr Biol. 2001;11:R986-96.

Marin R, Williams A, Hale S, Burge B, Mense M, Bauman R, Tortella F. The effect of voluntary exercise exposure on histological and neurobehavioral outcomes after ischemic brain injury in the rat. Physiol Behav. 2003;80:167-75.

Masliah E, Mallory M, Ge N, Alford M, Veinbergs I, Roses AD. Neurodegeneration in the central nervous system of apoE-deficient mice. Exp Neurol. 1995;136:107-22.

Masliah E, Mallory M, Hansen L, DeTeresa R, Alford M, Terry R. Synaptic and neuritic alterations during the progression of Alzheimer's disease. Neurosci Lett. 1994;174:67-72.

Masliah E, Mallory M, Hansen L, DeTeresa R, Terry RD. Quantitative synaptic alterations in the human neocortex during normal aging. Neurology. 1993;43:192-7.

Mastorakos G, Pavlatou M, Diamanti-Kandarakis E, Chrousos GP. Exercise and the stress system. Hormones (Athens). 2005;4:73-89. 
Matsuda S, Launey T, Mikawa S, Hirai H. Disruption of AMPA receptor GluR2 clusters following long-term depression induction in cerebellar Purkinje neurons. Embo J. 2000;19:2765-74.

Mattson MP. Neuroprotective signaling and the aging brain: take away my food and let me run. Brain Res. 2000;886:47-53.

McArdle WD, Katch FI, Katch, VL. Fisiologia do Exercício: energia, nutrição e desempenho humano. 4. ed. Rio de Janeiro: Guanabara Koogan;1998.

McCann JC, Ames BN. Is docosahexaenoic acid, an n-3 long-chain polyunsaturated fatty acid, required for development of normal brain function? An overview of evidence from cognitive and behavioral tests in humans and animals. Am J Clin Nutr. 2005;82:281-95.

Medhurst AD, Harrison DC, Read SJ, Campbell CA, Robbins MJ, Pangalos MN. The use of TaqMan RT-PCR assays for semiquantitative analysis of gene expression in CNS tissues and disease models. J Neurosci Methods. 2000;98:9-20.

Meeusen R, Smolders I, Sarre S, de Meirleir K, Keizer H, Serneels M, Ebinger G, Michotte $Y$. Endurance training effects on neurotransmitter release in rat striatum: an in vivo microdialysis study. Acta Physiol Scand. 1997;159:335-41.

Mello PB, Benetti F, Cammarota M, Izquierdo I. Effects of acute and chronic physical exercise and stress on different types of memory in rats. An Acad Bras Cienc. 2008; 80:301-9.

Messing A, Brenner M. GFAP: functional implications gleaned from studies of genetically engineered mice. Glia. 2003;43:87-90.

Mizutani K, Sonoda S, Hayashi N, Takasaki A, Beppu H, Saitoh E, Shimpo K. Analysis of protein expression profile in the cerebellum of cerebral infarction rats after treadmill training. Am J Phys Med Rehabil. 2010;89:107-14.

Molteni R, Wu A, Vaynman S, Ying Z, Barnard RJ, Gomez-Pinilla F. Exercise reverses the harmful effects of consumption of a high-fat diet on synaptic and behavioral plasticity associated to the action of brain-derived neurotrophic factor. Neuroscience. 2004a;123:429-40. 
Molteni R, Ying Z, Gomez-Pinilla F. Differential effects of acute and chronic exercise on plasticity-related genes in the rat hippocampus revealed by microarray. Eur $\mathrm{J}$ Neurosci. 2002;16:1107-16.

Molteni R, Zheng JQ, Ying Z, Gomez-Pinilla F, Twiss JL. Voluntary exercise increases axonal regeneration from sensory neurons. Proc Natl Acad Sci U S A. 2004b;101:8473-8.

Nakagawa S, Kim JE, Lee R, Malberg JE, Chen J, Steffen C, Zhang YJ, Nestler EJ, Duman RS. Regulation of neurogenesis in adult mouse hippocampus by cAMP and the cAMP response element-binding protein. J Neurosci. 2002;22:3673-82.

Nauli SM, Maher TJ, Pearce WJ, Ally A. Effects of opioid receptor activation on cardiovascular responses and extracellular monoamines within the rostral ventrolateral medulla during static contraction of skeletal muscle. Neurosci Res. 2001a;41:373-83.

Nauli SM, Pearce WJ, Amer A, Maher TJ, Ally A. Effects of nitric oxide and GABA interaction within ventrolateral medulla on cardiovascular responses during static muscle contraction. Brain Res. 2001b;922:234-42.

Naylor AS, Persson AI, Eriksson PS, Jonsdottir IH, Thorlin T. Extended voluntary running inhibits exercise-induced adult hippocampal progenitor proliferation in the spontaneously hypertensive rat. J Neurophysiol. 2005;93:2406-14.

Neeper SA, Gomez-Pinilla F, Choi J, Cotman C. Exercise and brain neurotrophins. Nature. 1995;373:109.

Neeper SA, Gomez-Pinilla F, Choi J, Cotman CW. Physical activity increases mRNA for brain-derived neurotrophic factor and nerve growth factor in rat brain. Brain Res. 1996;726:49-56.

Nestler EJ, Greengard P. Serine and Threonine Phosphorylation. In: Siegal GJ, Agranoff BW, Albers RW, Fisher SK, Uhler MD (editors). Basic Neurochemistry: Molecular, Cellular and Medical Aspects. 6th ed. Philadelphia: Lippincott, Williams \& Wilkins;1999.

Nichol KE, Parachikova AI, Cotman CW. Three weeks of running wheel exposure improves cognitive performance in the aged Tg2576 mouse. Behav Brain Res. 2007; 184:124-32. 
Nieman D. Exercício e Saúde. São Paulo: Manole;1999.

Nishijima T, Soya $\mathrm{H}$. Evidence of functional hyperemia in the rat hippocampus during mild treadmill running. Neurosci Res. 2006;54:186-91.

Noctor SC, Flint AC, Weissman TA, Dammerman RS, Kriegstein AR. Neurons derived from radial glial cells establish radial units in neocortex. Nature. 2001; 409:714-20.

Numakawa T, Suzuki S, Kumamaru E, Adachi N, Richards M, Kunugi H. BDNF function and intracellular signaling in neurons. Histol Histopathol. 2010; 25:237-58.

Osborne PG. Hippocampal and striatal blood flow during behavior in rats: chronic laser Doppler flowmetry study. Physiol Behav. 1997;61:485-92.

Overton JM, Redding MW, Yancey SL, Stremel RW. Hypothalamic GABAergic influences on treadmill exercise responses in rats. Brain Res Bull. 1994;33:517-22.

Pacak K. Stressor-specific activation of the hypothalamic-pituitary-adrenocortical axis. Physiol Res. 2000;49(Suppl 1):S11-7.

Paxinos G, Watson C. The rat brain - in stereotaxic coordinates. 5th ed. Burlington: Elsevier Academic Press;2005.

Paxinos G. The Rat Nervous System. 3rd ed. Amsterdam: Elsevier Academic Press; 2004.

Perea G, Araque A. Communication between astrocytes and neurons: a complex language. J Physiol Paris. 2002;96:199-207.

Peters O, Schipke CG, Hashimoto Y, Kettenmann H. Different mechanisms promote astrocyte $\mathrm{Ca}^{2+}$ waves and spreading depression in the mouse neocortex. J Neurosci. 2003;23:9888-9896.

Ploughman M, Granter-Button S, Chernenko G, Tucker BA, Mearow KM, Corbett D. Endurance exercise regimens induce differential effects on brain-derived neurotrophic factor, synapsin-I and insulin-like growth factor I after focal ischemia. Neuroscience. 2005;136:991-1001. 
Popa-Wagner A, Schroder E, Schmoll H, Walker LC, Kessler C. Upregulation of MAP1B and MAP2 in the rat brain after middle cerebral artery occlusion: effect of age. J Cereb Blood Flow Metab. 1999;19:425-34.

Poulton NP, Muir GD. Treadmill training ameliorates dopamine loss but not behavioral deficits in hemi-parkinsonian rats. Exp Neurol. 2005;193:181-97.

Pradelles P, Grassi J, Maclouf J. Enzyme immunoassays of eicosanoids using acetylcholine esterase as label: an alternative to radioimmunoassay. Anal Chem. 1985;57:1170-3.

Quinlan RA, Brenner M, Goldman JE, Messing A. GFAP and its role in Alexander disease. Exp Cell Res. 2007;313:2077-87.

Radak Z, Sasvari M, Nyakas C, Kaneko T, Tahara S, Ohno H, Goto S. Single bout of exercise eliminates the immobilization-induced oxidative stress in rat brain. Neurochem Int. 2001;39:33-8.

Ramanathan D, Conner JM, Tuszynski MH. A form of motor cortical plasticity that correlates with recovery of function after brain injury. Proc Natl Acad Sci U S A. 2006; 103:11370-5.

Real CC, Ferreira AF, Hernandes MS, Britto LR, Pires RS. Exercise-induced plasticity of AMPA-type glutamate receptor subunits in the rat brain. Brain Res. 2010;1363:63-71.

Redila VA, Olson AK, Swann SE, Mohades G, Webber AJ, Weinberg J, Christie BR. Hippocampal cell proliferation is reduced following prenatal ethanol exposure but can be rescued with voluntary exercise. Hippocampus. 2006;16:305-11.

Redila VA, Christie BR. Exercise-induced changes in dendritic structure and complexity in the adult hippocampal dentate gyrus. Neuroscience. 2006; 137:1299307.

Reidman DA, Maher TJ, Chaiyakul P, Ally A. Modulation of extracellular glutamate and pressor response to muscle contraction during NMDA-receptor blockade in the rostral ventrolateral medulla. Neurosci Res. 2000;36:147-56. 
Reines A, Cereseto M, Ferrero A, Sifonios L, Podesta MF, Wikinski S. Maintenance treatment with fluoxetine is necessary to sustain normal levels of synaptic markers in an experimental model of depression: correlation with behavioral response. Neuropsychopharmacology. 2008;33:1896-908.

Reinhard Jr. JF, Liebmann JE, Schlosberg AJ, Moskowitz MA. Serotonin neurons project to small blood vessels in the brain. Science. 1979;206:85-7.

Reisi P, Babri S, Alaei H, Sharifi MR, Mohaddes G, Lashgari R. Effects of treadmill running on short-term pre-synaptic plasticity at dentate gyrus of streptozotocininduced diabetic rats. Brain Res. 2008;1211:30-6.

Roberts LA, Large CH, Higgins MJ, Stone TW, O'Shaughnessy CT,Morris BJ. Increased expression of dendritic mRNA following the induction of long-term potentiation. Brain Res Mol Brain Res. 1998;56:38-44.

Rodrigues L, Dutra MF, Ilha J, Biasibetti R, Quincozes-Santos A, Leite MC, Marcuzzo $S$, Achaval M, Goncalves CA. Treadmill training restores spatial cognitive deficits and neurochemical alterations in the hippocampus of rats submitted to an intracerebroventricular administration of streptozotocin. J Neural Transm. 2010; 117:1295-305.

Rojas Vega S, Abel T, Lindschulten R, Hollmann W, Bloch W, Struder HK. Impact of exercise on neuroplasticity-related proteins in spinal cord injured humans. Neuroscience. 2008;153:1064-70.

Roy CS, Sherrington CS. On the Regulation of the Blood-supply of the Brain. J Physiol. 1890;11:85-158.

Rozman KK, Doull J. Scientific foundations of hormesis. Part 2. Maturation, strengths, limitations, and possible applications in toxicology, pharmacology, and epidemiology. Crit Rev Toxicol. 2003;33:451-62.

Russo-Neustadt A, Beard RC, Cotman CW. Exercise, antidepressant medications, and enhanced brain derived neurotrophic factor expression. Neuropsychopharmacology. 1999;21:679-82.

Russo-Neustadt AA, Beard RC, Huang YM, Cotman CW. Physical activity and antidepressant treatment potentiate the expression of specific brain-derived neurotrophic factor transcripts in the rat hippocampus. Neuroscience. 2000;101:30512. 
Salgado-Delgado R, Angeles-Castellanos M, Buijs MR, Escobar C. Internal desynchronization in a model of night-work by forced activity in rats. Neuroscience. 2008;154:922-31.

Salonen JT, Puska P, Tuomilehto J. Physical activity and risk of myocardial infarction, cerebral stroke and death: a longitudinal study in Eastern Finland. Am J Epidemiol. 1982;115:526-37.

Sambrook J, Russel DW. Molecular cloning: a laboratory manual. 3rd ed. New York: Cold Spring Harbor Laboratory Press;2001.

Sanchez C, Diaz-Nido J, Avila J. Phosphorylation of microtubule-associated protein 2 (MAP2) and its relevance for the regulation of the neuronal cytoskeleton function. Prog Neurobiol. 2000;61:133-68.

Sarbadhikari SN, Saha AK. Moderate exercise and chronic stress produce counteractive effects on different areas of the brain by acting through various neurotransmitter receptor subtypes: a hypothesis. Theor Biol Med Model. 2006;3:33.

Scopel D, Fochesatto C, Cimarosti H, Rabbo M, Bello-Klein A, Salbego C, Netto CA, Siqueira IR. Exercise intensity influences cell injury in rat hippocampal slices exposed to oxygen and glucose deprivation. Brain Res Bull. 2006;71:155-9.

Secretary of Health and Human Services and the Secretary of Education. Promoting better health for young people through physical activity and sports. Centers for Disease Control and Prevention. 2007. Disponível em: http://www.cdc.gov/healthyyouth/physicalactivity/promoting_health [2008 Set 25].

Seifert G, Schilling K, Steinhauser C. Astrocyte dysfunction in neurological disorders: a molecular perspective. Nat Rev Neurosci. 2006;7:194-206.

Shen K, Cowan CW. Guidance molecules in synapse formation and plasticity. Cold Spring Harb Perspect Biol. 2009;2:a001842.

Sherwin CM. Voluntary wheel running: a review and novel interpretation. Anim Behav. 1998;56:11-27. 
Sim YJ, Kim H, Kim JY, Yoon SJ, Kim SS, Chang HK, Lee TH, Lee HH, Shin MC, Shin MS, Kim CJ. Long-term treadmill exercise overcomes ischemia-induced apoptotic neuronal cell death in gerbils. Physiol Behav. 2005;84:733-8.

Siren AL, Knerlich F, Schilling L, Kamrowski-Kruck H, Hahn A, Ehrenreich H. Differential glial and vascular expression of endothelins and their receptors in rat brain after neurotrauma. Neurochem Res. 2000;25:957-69.

Sloviter RS, Dean E, Neubort S. Electron microscopic analysis of adrenalectomyinduced hippocampal granule cell degeneration in the rat: apoptosis in the adult central nervous system. J Comp Neurol. 1993;330:337-51.

Soya $\mathrm{H}$, Mukai A, Deocaris CC, Ohiwa N, Chang H, Nishijima T, Fujikawa T, Togashi $\mathrm{K}$, Saito T. Threshold-like pattern of neuronal activation in the hypothalamus during treadmill running: establishment of a minimum running stress (MRS) rat model. Neurosci Res. 2007a;58:341-8.

Soya $H$, Nakamura $T$, Deocaris CC, Kimpara A, limura M, Fujikawa $T$, Chang $H$, McEwen BS, Nishijima T. BDNF induction with mild exercise in the rat hippocampus. Biochem Biophys Res Commun. 2007b;358:961-7.

Steward O, Wallace CS. mRNA distribution within dendrites: relationship to afferent innervation. J Neurobiol. 1995;26:447-9.

Stranahan AM, Khalil D, Gould E. Running induces widespread structural alterations in the hippocampus and entorhinal cortex. Hippocampus. 2007;17:1017-22.

Stummer W, Weber K, Tranmer B, Baethmann A, Kempski O. Reduced mortality and brain damage after locomotor activity in gerbil forebrain ischemia. Stroke. 1994; 25:1862-9.

Sutoo D, Akiyama K. Regulation of brain function by exercise. Neurobiol Dis. 2003; 13:1-14.

Swain RA, Harris AB, Wiener EC, Dutka MV, Morris HD, Theien BE, Konda S, Engberg K, Lauterbur PC, Greenough WT. Prolonged exercise induces angiogenesis and increases cerebral blood volume in primary motor cortex of the rat. Neuroscience. 2003;117:1037-46. 
Tartaglia N, Du J, Tyler WJ, Neale E, Pozzo-Miller L, Lu B. Protein synthesisdependent and -independent regulation of hippocampal synapses by brain-derived neurotrophic factor. J Biol Chem. 2001;276:37585-93.

Timofeeva E, Huang Q, Richard D. Effects of treadmill running on brain activation and the corticotropin-releasing hormone system. Neuroendocrinology. 2003;77:388405.

Tong L, Shen H, Perreau VM, Balazs R, Cotman CW. Effects of exercise on geneexpression profile in the rat hippocampus. Neurobiol Dis. 2001;8:1046-56.

Tucker RP, Garner CC, Matus A. In situ localization of microtubule-associated protein mRNA in the developing and adult rat brain. Neuron. 1989;2:1245-56.

Tucker RP. The roles of microtubule-associated proteins in brain morphogenesis: a review. Brain Res Brain Res Rev. 1990;15:101-20.

Uda M, Ishido M, Kami K, Masuhara M. Effects of chronic treadmill running on neurogenesis in the dentate gyrus of the hippocampus of adult rat. Brain Res. 2006; 1104:64-72.

US Department of Health and Human Services. Healthy People 2010. 2000. Disponível em: http://www.healthypeople.gov/Document [2008 Set 25].

Uysal N, Tugyan K, Kayatekin BM, Acikgoz O, Bagriyanik HA, Gonenc S, Ozdemir D, Aksu I, Topcu A, Semin I. The effects of regular aerobic exercise in adolescent period on hippocampal neuron density, apoptosis and spatial memory. Neurosci Lett. 2005;383:241-5.

van Praag H, Christie BR, Sejnowski TJ, Gage FH. Running enhances neurogenesis, learning, and long-term potentiation in mice. Proc Natl Acad Sci U S A. 1999a; 96:13427-31.

van Praag H, Kempermann G, Gage FH. Running increases cell proliferation and neurogenesis in the adult mouse dentate gyrus. Nat Neurosci. 1999b;2:266-70.

van Praag H, Schinder AF, Christie BR, Toni N, Palmer TD, Gage FH. Functional neurogenesis in the adult hippocampus. Nature. 2002;415:1030-4. 
van Praag $\mathrm{H}$, Shubert $\mathrm{T}$, Zhao $\mathrm{C}$, Gage $\mathrm{FH}$. Exercise enhances learning and hippocampal neurogenesis in aged mice. J Neurosci. 2005;25:8680-5.

van Praag $\mathrm{H}$. Neurogenesis and exercise: past and future directions. Neuromolecular Med. 2008;10:128-40.

Vasuta C, Caunt C, James R, Samadi S, Schibuk E, Kannangara T, Titterness AK, Christie BR. Effects of exercise on NMDA receptor subunit contributions to bidirectional synaptic plasticity in the mouse dentate gyrus. Hippocampus. 2007; 17:1201-8.

Vaucher E, Hamel E. Cholinergic basal forebrain neurons project to cortical microvessels in the rat: electron microscopic study with anterogradely transported Phaseolus vulgaris leucoagglutinin and choline acetyltransferase immunocytochemistry. J Neurosci. 1995;15:7427-41.

Vaynman S, Ying Z, Yin D, Gomez-Pinilla F. Exercise differentially regulates synaptic proteins associated to the function of BDNF. Brain Res. 2006;1070:124-30. Vaynman S, Ying Z, Gomez-Pinilla F. Exercise induces BDNF and synapsin I to specific hippocampal subfields. J Neurosci Res. 2004a;76:356-62.

Vaynman S, Ying Z, Gomez-Pinilla F. Hippocampal BDNF mediates the efficacy of exercise on synaptic plasticity and cognition. Eur J Neurosci. 2004b;20:2580-90.

Vaynman S, Ying Z, Gomez-Pinilla F. Interplay between brain-derived neurotrophic factor and signal transduction modulators in the regulation of the effects of exercise on synaptic-plasticity. Neuroscience. 2003;122:647-57.

Vaynman S, Gomez-Pinilla F. License to run: exercise impacts functional plasticity in the intact and injured central nervous system by using neurotrophins. Neurorehabil Neural Repair. 2005;19:283-95.

Vissing $\mathrm{J}$, Andersen $\mathrm{M}$, Diemer $\mathrm{NH}$. Exercise-induced changes in local cerebral glucose utilization in the rat. J Cereb Blood Flow Metab. 1996;16:729-36.

von Bohlen Und Halbach O. Immunohistological markers for staging neurogenesis in adult hippocampus. Cell Tissue Res. 2007; 329,409-20.

von Duvillard SP. Exercise lactate levels: simulation and reality of aerobic and anaerobic metabolism. Eur J Appl Physiol. 2001;86:3-5. 
Vrba R. Significance of glutamic acid in metabolic processes in the rat brain during physical exercise. Nature. 1955;176:1258-61.

Wang RY, Yang YR, Yu SM. Protective effects of treadmill training on infarction in rats. Brain Res. 2001;922:140-3.

Wang $\mathrm{T}$, Xie K, Lu B. Neurotrophins promote maturation of developing neuromuscular synapses. J Neurosci. 1995;15:4796-805.

Wasserman K, Whipp BJ, Koyl SN, Beaver WL. Anaerobic threshold and respiratory gas exchange during exercise. J Appl Physiol. 1973;35:236-43.

Williams CA, Gopalan R, Nichols PL, Brien PL. Fatiguing isometric contraction of hind-limb muscles results in the release of immunoreactive neurokinins from sites in the rostral medulla in the anesthetized cat. Neuropeptides. 1995;28:209-18.

Wilmore JH, Costil D. Fisiologia do Esporte e do Exercício. São Paulo: Manole;2001.

Winter B, Breitenstein C, Mooren FC, Voelker K, Fobker M, Lechtermann A, Krueger K, Fromme A, Korsukewitz C, Floel A, Knecht S. High impact running improves learning. Neurobiol Learn Mem. 2007;87:597-609.

Witkowski S, Hagberg JM. Progenitor cells and age: can we fight aging with exercise? J Appl Physiol. 2007;102:834-5.

Wu A, Ying Z, Gomez-Pinilla F. Omega-3 fatty acids supplementation restores mechanisms that maintain brain homeostasis in traumatic brain injury. J Neurotrauma. 2007;24:1587-95.

Yamamoto $\mathrm{T}$, Ohkuwa $\mathrm{T}$, Itoh $\mathrm{H}$, Sato $\mathrm{Y}$, Naoi M. Relation between voluntary physical activity and oxidant/antioxidant status in rats. Comp Biochem Physiol C Toxicol Pharmacol. 2003;135:163-8.

Yang G, Chen G, Ebner TJ, ladecola C. Nitric oxide is the predominant mediator of cerebellar hyperemia during somatosensory activation in rats. Am J Physiol. 1999; 277:R1760-70. 
Ying Z, Roy RR, Edgerton VR, Gomez-Pinilla F. Exercise restores levels of neurotrophins and synaptic plasticity following spinal cord injury. Exp Neurol. 2005; 193:411-9.

Ying Z, Roy RR, Zhong H, Zdunowski S, Edgerton VR, Gomez-Pinilla F. Brainderived neurotrophic factor-exercise interactions in the recovery of symmetrical stepping after a cervical hemisection in rats. Neuroscience. 2008;155:1070-1078.

Yoon MC, Shin MS, Kim TS, Kim BK, Ko IG, Sung YH, Kim SE, Lee HH, Kim YP, Kim CJ. Treadmill exercise suppresses nigrostriatal dopaminergic neuronal loss in 6hydroxydopamine-induced Parkinson's rats . Neurosci Lett. 2007; 423:12-17.

Yu IT, Lee SH, Lee YS, Son H. Differential effects of corticosterone and dexamethasone on hippocampal neurogenesis in vitro. Biochem Biophys Res Commun. 2004;317:484-90.

Zhao C, Deng W, Gage FH. Mechanisms and functional implications of adult neurogenesis. Cell. 2008;132:645-60.

Zhu H, Dahlstrom A. Glial fibrillary acidic protein-expressing cells in the neurogenic regions in normal and injured adult brains. J Neurosci Res. 2007;85:2783-92.

Zonta M, Angulo MC, Gobbo S, Rosengarten B, Hossmann KA, Pozzan T, Carmignoto G. Neuron-to-astrocyte signaling is central to the dynamic control of brain microcirculation. Nat Neurosci. 2003;6:43-50. 


\section{ANEXO A - Artigo Publicado}

Ferreira AF, Real CC, Rodrigues AC, Alves AS, Britto LR. Moderate exercise changes synaptic and cytoskeletal proteins in motor regions of the rat brain. Brain Res. 2010; 1361:31-42. 
Provided for non-commercial research and education use. Not for reproduction, distribution or commercial use.

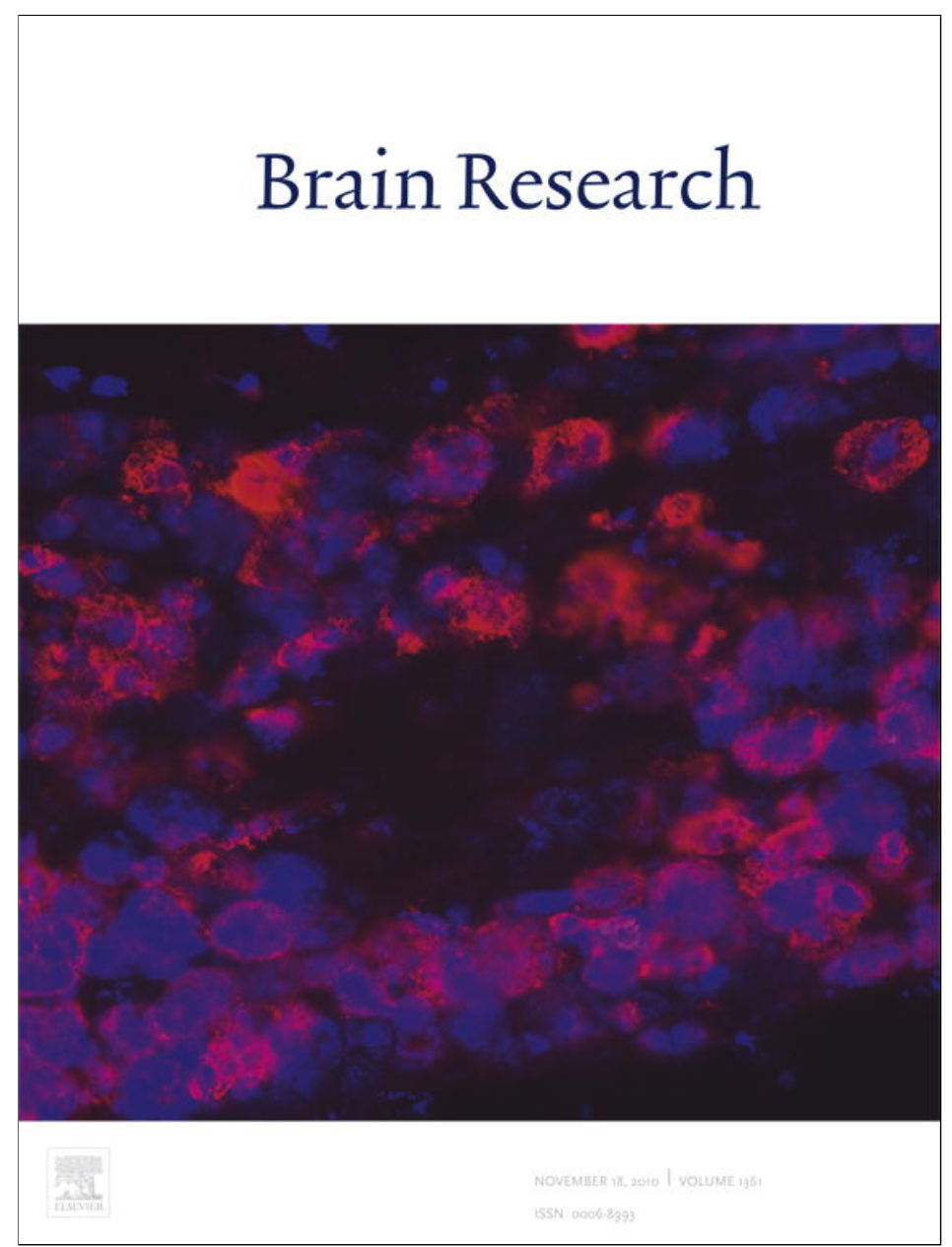

This article appeared in a journal published by Elsevier. The attached copy is furnished to the author for internal non-commercial research and education use, including for instruction at the authors institution and sharing with colleagues.

Other uses, including reproduction and distribution, or selling or licensing copies, or posting to personal, institutional or third party websites are prohibited.

In most cases authors are permitted to post their version of the article (e.g. in Word or Tex form) to their personal website or institutional repository. Authors requiring further information regarding Elsevier's archiving and manuscript policies are encouraged to visit:

http://www.elsevier.com/copyright 


\title{
Research Report
}

\section{Moderate exercise changes synaptic and cytoskeletal proteins in motor regions of the rat brain}

\author{
Ana F.B. Ferreira ${ }^{a, *}$, Caroline C. Real ${ }^{a}$, Alice C. Rodrigues ${ }^{b}$, \\ Adilson S. Alves ${ }^{a}$, Luiz R.G. Britto ${ }^{a}$ \\ ${ }^{a}$ Department of Physiology and Biophysics, Institute of Biomedical Sciences, University of São Paulo, São Paulo, SP, Brazil \\ ${ }^{\mathrm{b}}$ Department of Clinical and Toxicological Analysis, Faculty of Pharmaceutical Sciences, University of São Paulo, São Paulo, SP, Brazil
}

\section{A R T I C L E I N F O}

Article history:

Accepted 14 September 2010

Available online 19 September 2010

Keywords:

Physical exercise

Plasticity

Synapsin I

Synaptophysin

Neurofilaments

\begin{abstract}
A B S T R A C T
Physical exercise is known to enhance brain function in several aspects. We evaluated the acute effects of a moderate forced exercise protocol on synaptic proteins, namely synapsin I (SYN) and synaptophysin (SYP), and structural proteins (neurofilaments, NFs) in rat brain regions related to motor function and often affected by neurodegenerative disorders. Immunohistochemistry, Western blotting and real-time PCR were used to analyze the expression of those proteins after 3, 7 and 15 days of exercise (EX3, EX7 and EX15). In the cerebellum, increase of SYN was observed at EX7 and EX15 and of NF68 at EX3. In the substantia nigra, increases of protein levels were observed for NF68 and NF160 at EX3. In the striatum, there was an increase of SYN at EX3 and EX7, of SYP at EX7 and of NF68 at EX3. In the cortex, decreased levels of NF68 and NF160 were observed at EX3, followed by an increase of NF68 at EX15. In the reticular formation, all NF proteins were increased at EX15. The mRNA data for each time-point and region also revealed significant exercise-related changes of SYN, SYP and NF expression. These results suggest that moderate physical exercise modulates synaptic and structural proteins in motor brain areas, which may play an important role in the exercisedependent brain plasticity.
\end{abstract}

(c) 2010 Elsevier B.V. All rights reserved.

\section{Introduction}

Increasing evidence shows that various forms of physical exercise are beneficial to the central nervous system (CNS) of humans (Dustman et al., 1990; Kramer et al., 1999; Lupinacci et al., 1993) and animals (Gomez-Pinilla et al., 2002; Marin et al., 2003; Molteni et al., 2002; Vaynman et al., 2004; Ying et al., 2005). Exercise enhances brain function by improving neuroplasticity, learning, memory and cognition (Lambert et al., 2005; Molteni et al., 2002, 2004; Neeper et al., 1995; van
Praag et al., 2005; Vaynman et al., 2004) and has been associated with structural changes such as angiogenesis (Isaacs et al., 1992), synaptogenesis and neurogenesis (Eadie et al., 2005; Redila and Christie, 2006; Redila et al., 2006; van Praag et al., 1999, 2002). Protective effects against several neurological diseases (Dishman et al., 2006) including Parkinson's disease (Smith and Zigmond, 2003), Alzheimer's disease (Cotman and Berchtold, 2002; Mirochnic et al., 2009), and ischemic stroke (Stummer et al., 1994) have been suggested, along with the reduction of the number and severity of

\footnotetext{
* Corresponding author. Laboratory of Cellular Neurobiology, Department of Physiology and Biophysics, Institute of Biomedical Sciences, University of São Paulo, Av. Prof. Lineu Prestes, 1524 São Paulo, SP 05508-900, Brazil. Fax: +55 1130917426.

E-mail address: anafferreira@usp.br (A.F.B. Ferreira).
} 
seizures in animal models of epilepsy (Arida et al., 2007). Exercise also provides a neuroprotective effect against the mental decline associated with aging (Laurin et al., 2001) and against injuries to the CNS (Cotman and Berchtold, 2002; Gentile et al., 1987), facilitating the recovery as well (Edgerton et al., 2004; Grealy et al., 1999; Mattson, 2000). The reorganization of the sensory and motor cortices, for example, is an important component of recovery after neural injury and as a result of learning (Kleim et al., 2002; Nudo et al., 1996; Xerri et al., 1998). Cortical reorganization is believed to reflect the

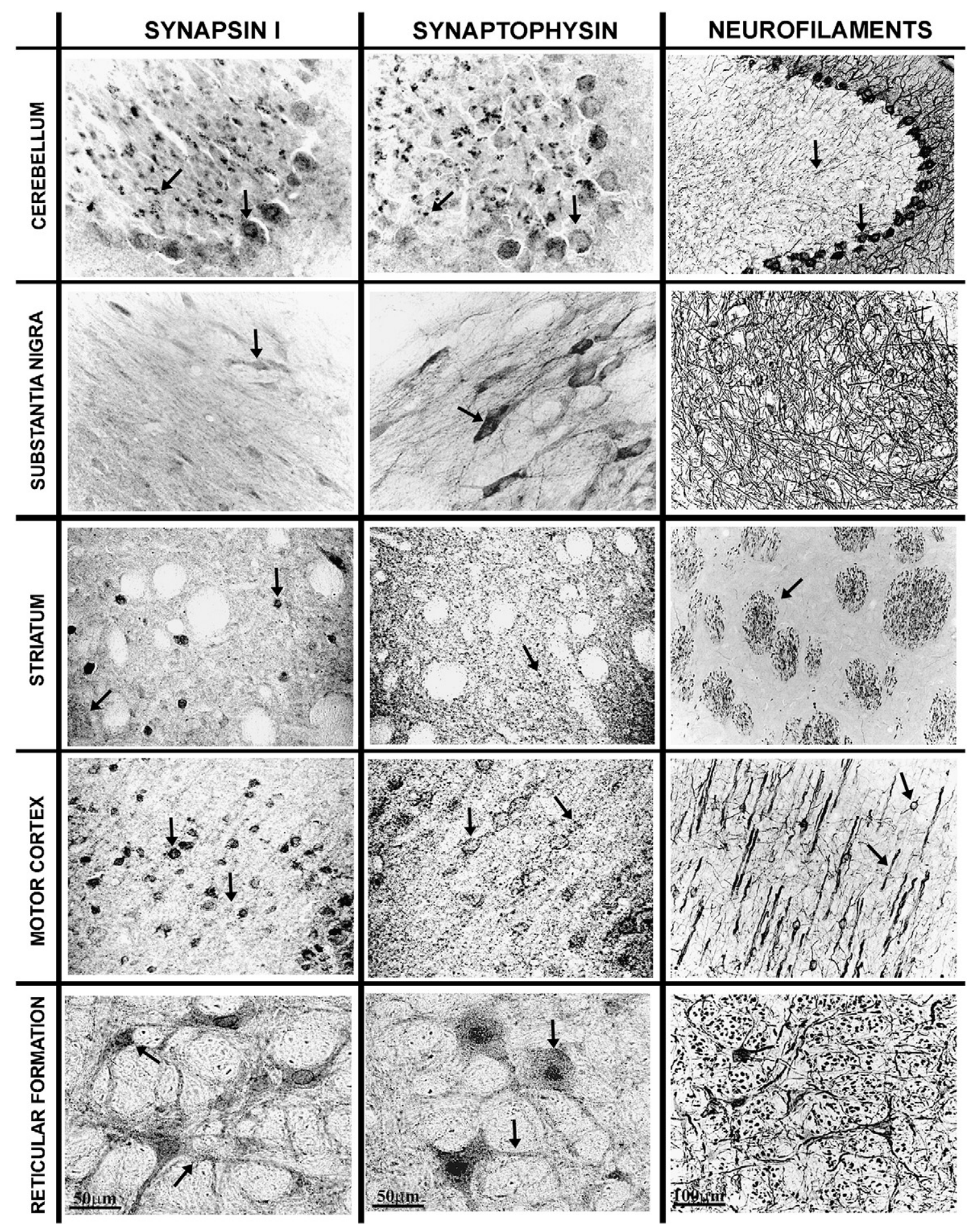

Fig. 1 - Digital images of coronal sections illustrating the staining pattern for synapsin I, synaptophysin and neurofilaments in the cerebellum, substantia nigra, striatum, motor cortex and reticular formation. Note perikarya staining in Purkinje cells, motor cortex and reticular formation for all three antibodies, in the substantia nigra for SYN and SYP and in the striatum for SYN (arrows). Neuropil staining was also observed in several instances (arrows). 
integration of several plasticity processes over large populations of neurons (Florence et al., 1998; Kilgard and Merzenich, 1998; Pons et al., 1991; Sanes and Donoghue, 2000).

But what is a viable exercise program in a condition of neurological deficit? In cases of injuries or neurological diseases, the intervention requires light to moderate intensity exercise protocols depending on the extent of the deficit (Ferrer-Alcon et al., 2008; Lui and Byl, 2009; Ridgel et al., 2009). Significant functional improvements are seen in most cases, but the amount of improvement that was actually due to the exercise intervention is not known, since the brain has the ability to partially recover on its own after an injury (Sadowsky and McDonald, 2009). Even for normal individuals, the recommended guideline for physical exercise is at least $30 \mathrm{~min}$ of moderate-intensity physical activity on most days of the week (Hillman et al., 2008).

We tried to approach these issues by evaluating how an animal model of moderate exercise protocol could influence the brain. Our choices of study were brain regions involved with the motor control and which are commonly affected by injuries or neurodegenerative disorders, namely the cerebellum, substantia nigra, striatum, motor cortex and reticular formation. It should be stressed that the literature lacks emphasis on the mechanisms involved in the plasticity of brain regions related to actual motor control, whereas the hippocampus and the brainstem cardiovascular control areas have been major targets of such studies. We narrowed our scope to investigate proteins considered as markers of synaptic density, such as the vesicle proteins synapsin I (SYN) and synaptophysin (SYP), and markers of neuronal structure, such as the cytoskeletal neurofilaments (NFs).

\section{Results}

Our immunohistochemistry results for anti-SYN and anti-SYP showed a cytoplasmic pattern of staining along with a puntiform-granular pattern of staining in regions with high synaptic density. NF staining was more visible along processes, as presented in Fig. 1. As the immunohistochemical reaction is hardly a quantitative technique, we preferred not to quantify the effects of moderate exercise on immunostaining and used only the protein and mRNA quantitative data to draw our conclusions. Nevertheless, it was possible to observe qualitative differences of immunostaining in several instances, as shown in the sample figures below. Western blotting and realtime PCR data were therefore used to quantitatively evaluate the results from different groups (sedentary: S; 3, 7 and 15 days of exercise training: EX3, EX7 and EX15, respectively) and in different brain regions, as follows. These results are summarized in Table 1 where the values described for Western blotting are relative optical densities (protein bands/ $\beta$-actin

Table 1 - Protein and mRNA levels for synaptic and structural elements after different periods of moderate exercise.

\begin{tabular}{|c|c|c|c|c|c|c|c|c|c|}
\hline \multirow[t]{3}{*}{ Brain region } & \multirow[t]{3}{*}{ Protein } & \multicolumn{4}{|c|}{ Western blotting } & \multicolumn{4}{|c|}{ Real-time PCR } \\
\hline & & S & EX3 & EX7 & EX15 & $\mathrm{S}$ & EX3 & EX7 & EX15 \\
\hline & & $\begin{array}{c}\text { Mean } \\
( \pm \text { SEM })\end{array}$ & $\begin{array}{c}\text { Mean } \\
( \pm \text { SEM })\end{array}$ & $\begin{array}{c}\text { Mean } \\
( \pm \text { SEM })\end{array}$ & $\begin{array}{c}\text { Mean } \\
( \pm \text { SEM })\end{array}$ & $\begin{array}{c}\text { Mean } \\
( \pm \text { SEM })\end{array}$ & $\begin{array}{c}\text { Mean } \\
( \pm \text { SEM })\end{array}$ & $\begin{array}{c}\text { Mean } \\
( \pm \text { SEM })\end{array}$ & $\begin{array}{c}\text { Mean } \\
( \pm \text { SEM })\end{array}$ \\
\hline \multirow[t]{5}{*}{ Cerebellum } & SYN & $1( \pm 0.05)$ & $1.25( \pm 0.11)$ & $1.30( \pm 0.06)^{*}$ & $1.34( \pm 0.10)^{*}$ & $1( \pm 0.21)$ & $2.44( \pm 0.55)$ & $1.70( \pm 0.46)$ & $2.24( \pm 0.54)$ \\
\hline & SYP & $1( \pm 0.15)$ & $1.29( \pm 0.30)$ & $1.15( \pm 0.13)$ & $1.17( \pm 0.17)$ & $1( \pm 0.61)$ & $11.38( \pm 9.96)$ & $3.47( \pm 1.60)$ & $12.30( \pm 7.03)$ \\
\hline & NF68 & $1( \pm 0.21)$ & $1.92( \pm 0.21)^{*}$ & $1.26( \pm 0.28)$ & $1.12( \pm 0.25)$ & $1( \pm 0.07)$ & $1.47( \pm 0.27)$ & $1.16( \pm 0.08)$ & $1.22( \pm 0.07)$ \\
\hline & NF160 & $1( \pm 0.18)$ & $1.68( \pm 0.34)$ & $1.31( \pm 0.32)$ & $1.01( \pm 0.12)$ & $1( \pm 0.12)$ & $0.97( \pm 0.06)$ & $0.98( \pm 0.06)$ & $1.18( \pm 0.13)$ \\
\hline & NF200 & nd & nd & nd & nd & $1( \pm 0.09)$ & $1.13( \pm 0.10)$ & $1.00( \pm 0.18)$ & $0.95( \pm 0.12)$ \\
\hline \multirow[t]{5}{*}{ Substantia nigra } & SYN & $1( \pm 0.19)$ & $1.18( \pm 0.27)$ & $1.49( \pm 0.43)$ & $0.95( \pm 0.15)$ & $1( \pm 0.62)$ & $2.92( \pm 0.36)^{*}$ & $3.18( \pm 0.42)^{* *}$ & $2.21( \pm 0.30)$ \\
\hline & SYP & $1( \pm 0.12)$ & $1.06( \pm 0.17)$ & $1.66( \pm 0.35)$ & $1.10( \pm 0.13)$ & $1( \pm 0.44)$ & $4.26( \pm 1.07)^{* * *}$ & $0.51( \pm 0.05)$ & $0.68( \pm 0.16)$ \\
\hline & NF68 & $1( \pm 0.23)$ & $2.80( \pm 0.68)^{* *}$ & $0.95( \pm 0.15)$ & $1.47( \pm 0.26)$ & $1( \pm 0.10)$ & $2.32( \pm 0.36)^{*}$ & $1.71( \pm 0.24)$ & $1.39( \pm 0.33)$ \\
\hline & NF160 & $1( \pm 0.19)$ & $2.82( \pm 0.59)^{* *}$ & $1.31( \pm 0.20)$ & $1.40( \pm 0.27)$ & $1( \pm 0.17)$ & $1.48( \pm 0.19)$ & $1.12( \pm 0.10)$ & $1.13( \pm 0.18)$ \\
\hline & NF200 & nd & nd & nd & nd & $1( \pm 0.16)$ & $1.69( \pm 0.24)$ & $1.52( \pm 0.24)$ & $1.77( \pm 0.11)$ \\
\hline \multirow[t]{5}{*}{ Striatum } & SYN & $1( \pm 0.04)$ & $1.37( \pm 0.14)^{*}$ & $1.37( \pm 0.09) *$ & $0.92( \pm 0.10)$ & $1( \pm 0.14)$ & $1.49( \pm 0.13)^{*}$ & $1.31( \pm 0.09)$ & $0.82( \pm 0.12)$ \\
\hline & SYP & $1( \pm 0.04)$ & $0.97( \pm 0.13)$ & $1.31( \pm 0.09)$ * & $1.30( \pm 0.08)$ & $1( \pm 0.17)$ & $1.26( \pm 0.11)$ & $1.24( \pm 0.16)$ & $0.44( \pm 0.11)^{*}$ \\
\hline & NF68 & $1( \pm 0.12)$ & $2.53( \pm 0.51)^{* *}$ & $1.19( \pm 0.16)$ & $1.03( \pm 0.13)$ & $1( \pm 0.15)$ & $0.82( \pm 0.07)$ & $0.62( \pm 0.07)^{*}$ & $0.44( \pm 0.06)^{* *}$ \\
\hline & NF160 & nd & nd & nd & nd & $1( \pm 0.08)$ & $1.07( \pm 0.12)$ & $1.08( \pm 0.12)$ & $1.11( \pm 0.09)$ \\
\hline & NF200 & nd & nd & nd & nd & $1( \pm 0.15)$ & $1.15( \pm 0.10)$ & $0.96( \pm 0.05)$ & $0.50( \pm 0.07)^{*}$ \\
\hline \multirow[t]{5}{*}{ Motor cortex } & SYN & $1( \pm 0.19)$ & $1.02( \pm 0.10)$ & $1.03( \pm 0.09)$ & $0.94( \pm 0.18)$ & $1( \pm 0.05)$ & $0.60( \pm 0.13)$ & $0.93( \pm 0.14)$ & $0.99( \pm 0.16)$ \\
\hline & SYP & $1( \pm 0.13)$ & $0.97( \pm 0.16)$ & $0.95( \pm 0.05)$ & $1.07( \pm 0.23)$ & $1( \pm 0.07)$ & $0.97( \pm 0.21)$ & $0.75( \pm 0.11)$ & $0.86( \pm 0.11)$ \\
\hline & NF68 & $1( \pm 0.11)$ & $0.37( \pm 0.10)^{*}$ & $0.64( \pm 0.08)$ & $1.57( \pm 0.25)^{*}$ & $1( \pm 0.12)$ & $1.02( \pm 0.23)$ & $1.16( \pm 0.14)$ & $1.48( \pm 0.17)$ \\
\hline & NF160 & $1( \pm 0.13)$ & $0.47( \pm 0.10)^{*}$ & $0.69( \pm 0.15)$ & $0.97( \pm 0.13)$ & $1( \pm 0.11)$ & $1.10( \pm 0.15)$ & $1.28( \pm 0.14)$ & $1.55( \pm 0.22)$ \\
\hline & NF200 & nd & nd & nd & nd & $1( \pm 0.04)$ & $0.79( \pm 0.13)$ & $0.92( \pm 0.13)$ & $1.15( \pm 0.12)$ \\
\hline \multirow[t]{5}{*}{ Reticular formation } & SYN & $1( \pm 0.15)$ & $1.06( \pm 0.09)$ & $1.20( \pm 0.06)$ & $1.02( \pm 0.10)$ & $1( \pm 0.10)$ & $1.34( \pm 0.34)$ & $1.58( \pm 0.25)$ & $1.38( \pm 0.32)$ \\
\hline & SYP & $1( \pm 0.10)$ & $1.07( \pm 0.05)$ & $1.02( \pm 0.06)$ & $0.99( \pm 0.08)$ & $1( \pm 0.14)$ & $1.63( \pm 0.66)$ & $1.04( \pm 0.23)$ & $1.63( \pm 0.44)$ \\
\hline & NF68 & $1( \pm 0.07)$ & $0.83( \pm 0.12)$ & $1.02( \pm 0.17)$ & $1.76( \pm 0.23)^{*}$ & $1( \pm 0.07)$ & $1.18( \pm 0.09)$ & $1.38( \pm 0.06)^{*}$ & $1.07( \pm 0.10)$ \\
\hline & NF160 & $1( \pm 0.12)$ & $0.76( \pm 0.13)$ & $1.45( \pm 0.45)$ & $2.86( \pm 0.62)^{*}$ & $1( \pm 0.07)$ & $1.41( \pm 0.06)^{*}$ & $1.56( \pm 0.04)^{* * *}$ & $1.39( \pm 0.09)^{* *}$ \\
\hline & NF200 & $1( \pm 0.09)$ & $0.95( \pm 0.15)$ & $1.15( \pm 0.26)$ & $2.31( \pm 0.48)^{*}$ & $1( \pm 0.07)$ & $1.15( \pm 0.11)$ & $1.17( \pm 0.16)$ & $1.01( \pm 0.08)$ \\
\hline
\end{tabular}

S: sedentary; EX3: exercise training for 3 days; EX7: exercise training for 7 days; EX15: exercise training for 15 days; SYN: synapsin I; SYP: synaptophysin; NF68: neurofilament $68 \mathrm{kDa}$; NF160: neurofilament $160 \mathrm{kDa}$; NF200: neurofilament $200 \mathrm{kDa}$; nd: not detected $\left({ }^{*} p<0.05 ;{ }^{* *} p<0.01\right.$; ${ }^{* * *} p<0.001$ vs. sedentary groups). 
bands) and values for the real-time PCR correspond to the relative mRNA expression (genes of interest/housekeeping genes). All values and statistical significance are given in relation to the control, sedentary groups.

\subsection{Cerebellum}

In the cerebellum, all three antibodies used produced cytoplasmic staining of the Purkinje cells. Whereas for SYN and SYP we observed clusters in the granular cell layer, NF staining was seen along dendritic and axonal processes in both granular and molecular layers (Fig. 1). It should be stressed that we mainly analyzed the cerebellum between 10 and $12 \mathrm{~mm}$ behind the bregma (Paxinos and Watson, 2005).

Western blotting analysis of the cerebellum revealed statistically significant increases at EX7 and EX15 for the levels of SYN $(p<0.05)$ (Fig. 2) and at EX3 for the levels of NF68 $(p<0.05)$, as shown in Table 1 . There were no exercise-induced changes of any mRNA evaluated in the cerebellum.

\subsection{Substantia nigra}

An exception to the pattern of staining for anti-SYN was observed in the substantia nigra, which was very faint and difficult to identify (Fig. 1). As for SYP, a cytoplasmic labeling prevailed, whereas the staining for NFs formed a dense net of processes (Fig. 1). This pattern of staining was in general observed for both main subdivisions of the substantia nigra, namely the pars compacta and the pars reticulata.

SYN mRNA expression was increased at EX3 $(p<0.05)$ and EX7 $(p<0.01)$, whereas SYP mRNA was increased only at EX3 $(p<0.001)$, even though both protein levels remained unchanged. For the NFs, there was an increase of the protein levels of NF160 and NF68 at EX3 $(p<0.01)$, whereas only NF68 mRNA expression was increased at EX3 $(p<0.05)$ (Table 1$)$.

\subsection{Striatum}

In the rostral striatum (between 1 and $2 \mathrm{~mm}$ rostral to the bregma), the staining for SYN and SYP was very diffuse and only SYN appeared in perikarya, whereas for NFs we observed a punctuate pattern of staining (Fig. 1).

There were statistically significant increases of the expression of SYN mRNA at EX3 $(p<0.05)$, whereas the levels of SYN were increased at EX3 and EX7 $(p<0.05)$. As for SYP, protein levels increased at EX7 $(p<0.05)$, but its mRNA expression decreased at EX15 ( $p<0.05)$ (Table 1) (Fig. 3).

For the NFs, we observed decreases of the expression of NF200 mRNA at EX15 $(p<0.05)$ and of NF68 mRNA at EX7 and EX15 $(p<0.05$ and $p<0.01$, respectively), preceded by an increase of protein levels of NF68 at EX3 $(p<0.01)$ (Table 1).

\subsection{Motor cortex}

In the motor cortex, the labeling for SYN and SYP was also very diffuse with a dense cytoplasmic staining, whereas for NFs the pattern of staining was similar to the one found in the cerebellum, with labeling along processes and in perikarya (Fig. 1). This analysis was focused on an intermediate area of the primary motor cortex, between 1 and $2 \mathrm{~mm}$ rostral to the bregma.

As for the protein levels, we observed changes only for the NFs. There was a decrease of the levels of NF160 at EX3 $(p<0.05)$, and levels of NF68 decreased at EX3 $(p<0.05)$ and increased at EX15 $(p<0.05)$ (Table 1).

\subsection{Reticular formation}

The staining for SYN e SYP in the reticular formation (e.g., the gigantocellular nucleus and neighboring areas; between 10 and $12 \mathrm{~mm}$ behind the bregma) was very similar to what was observed in the motor cortex, whereas the staining for NFs appeared in neuropil and perikarya (Fig. 1).

Whereas there were no changes in the protein levels and mRNA expression of SYN and SYP, the reticular formation showed increased levels of all NFs at EX15 $(p<0.05)$ and increases of the NF160 mRNA expression at all exercise periods ( $p<0.05$ for EX3, $p<0.001$ for EX7 and $p<0.01$ for EX15) and of the NF68 mRNA expression at EX7 $(p<0.05)$ (Table 1) (Fig. 4).
A

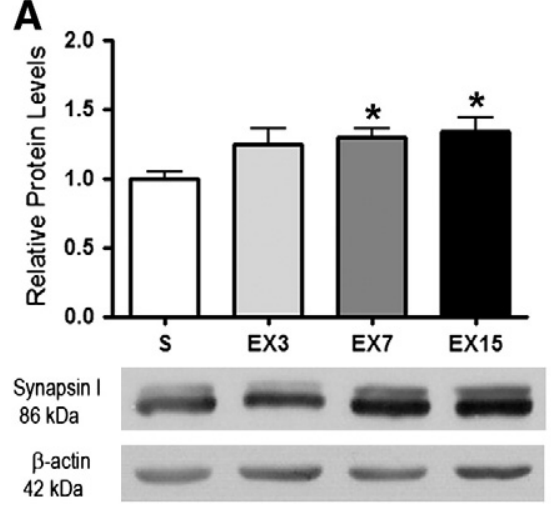

B

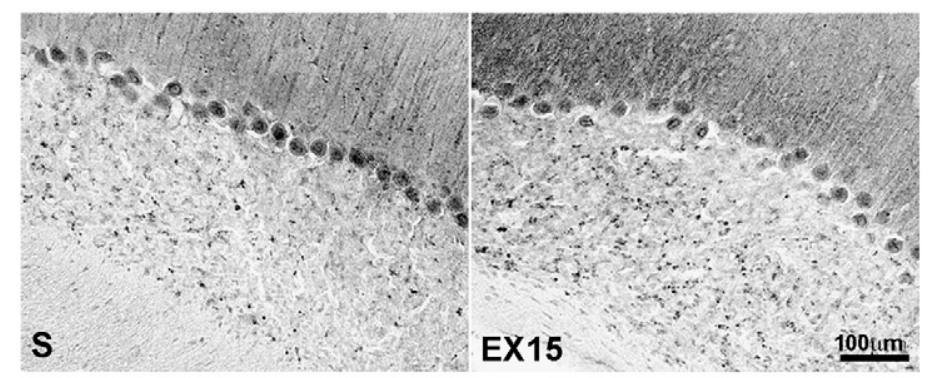

Fig. 2 - Sample figure illustrating the effects of treadmill running on SYN in the cerebellum. (A) Mean ratio of SYN/ $\beta$-actin densitometry density data relative to the sedentary group (normalized) and typical immunoblots in each condition. (B) Immunohistochemistry for SYN in the cerebellum showing an increased staining at EX15, especially in the granule cell and molecular layers. SYN: synapsin I; S: sedentary; EX3: exercise training for 3 days; EX7: exercise training for 7 days; EX15: exercise training for 15 days $\left({ }^{*} p<0.05\right)$. 

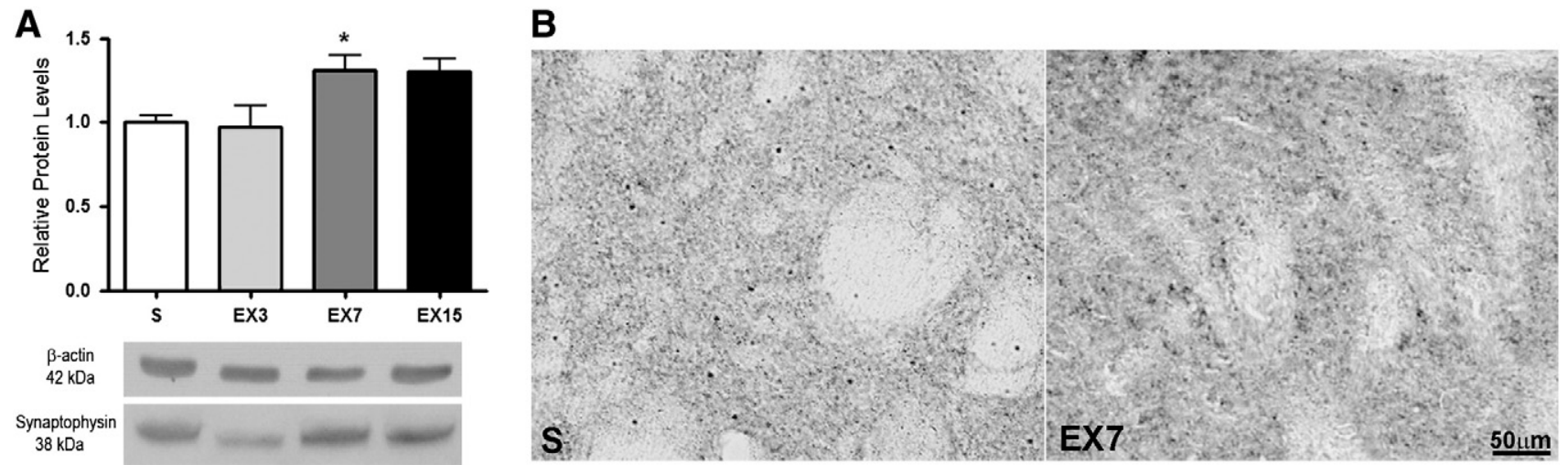

Fig. 3 - Sample figure illustrating the effects of treadmill running on SYP in the striatum. (A) Mean ratio of SYP/ $\beta$-actin densitometry density data relative to the sedentary group (normalized) and typical immunoblots in each condition.

(B) Immunohistochemistry for SYP in the striatum showing apparent increase of staining at EX7. SYP: synaptophysin; S: sedentary; EX3: exercise training for 3 days; EX7: exercise training for 7 days; EX15: exercise training for 15 days ( $p<0.05)$.

\section{Discussion}

In the present study, we aimed at analyzing the effects of moderate exercise on synaptic and cytoskeletal proteins in motor-related areas of the rat brain. Plastic changes were observed in those brain areas for all proteins studied, namely SYN, SYP and NFs, and the effects were different among the different proteins and areas. The synapsins are a family of neuronal phosphoproteins which modulate neurotransmitter
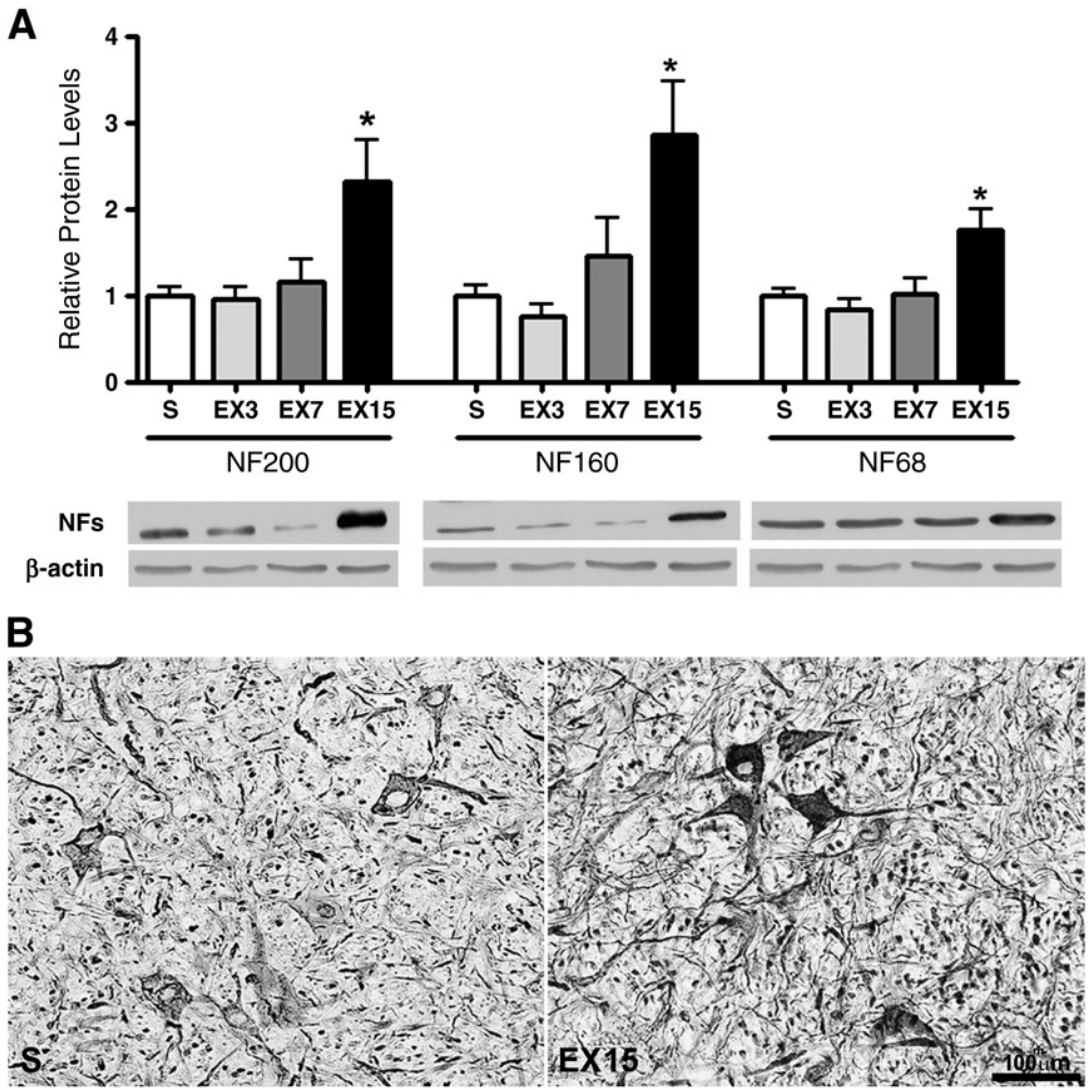

Fig. 4 - Sample figure illustrating the effects of treadmill running on NF200, NF160 and NF68 in the reticular formation. (A) Mean ratio of $\mathrm{NFs} / \boldsymbol{\beta}$-actin densitometry density data relative to the sedentary group (normalized) and typical immunoblots in each condition. (B) Immunohistochemistry for NFs in the reticular formation showing an increased staining at EX15. NFs: neurofilaments; NF200: neurofilament 200 kDa; NF160: neurofilament 160 kDa; NF68: neurofilament 68 kDa; S: sedentary; EX3: exercise training for 3 days; EX7: exercise training for 7 days; EX15: exercise training for 15 days $\left({ }^{*} p<0.05\right)$. 
release at the presynaptic terminal controlling the availability of synaptic vesicles by reversibly attaching them to the cytoskeleton. They are considered to be involved in synaptic vesicle docking, fusion and recycling (reviewed by Cesca et al., 2010). The synaptophysins, on the other hand, although abundant, have less clear functions. They appear to be involved in endocytosis and the recycling of synaptic vesicles (reviewed by Evans and Cousin, 2005). Neurofilaments appear to be involved in shaping neurons and in axonal transport (Hirokawa, 1991; Yuan et al., 2009). Our data, therefore, may suggest that SYN and SYP changes could be related to adjustments of synaptic efficacy induced by training, whereas NF changes could reflect neuronal remodeling which may also be related to synaptic plasticity and efficiency.

In this study we chose to use a treadmill for the exercise protocol, which is characterized as forced exercise, since the animal has to run at a predetermined speed (Arida et al., 2004). Treadmill exercise has the advantage of resembling what is practiced by humans (Winter et al., 2007), and is a key component of many neurological rehabilitation programs (Holschneider et al., 2007). In order to minimize stress, we started the exercise protocol with an adaptation period and used a predetermined running speed considered to be of low to moderate intensity (Felix and Michelini, 2007). Cortisol levels are increased in rats after higher speed exercise protocols (Ploughman et al., 2005). When submitted to stressful exercise protocols ( $1 \mathrm{~h}$ at $25 \mathrm{~m} / \mathrm{min}$ ) without familiarization to the treadmill, the rats became very stressed and showed increased responses of the amygdala (Timofeeva et al., 2003; Vissing et al., 1996). Nonetheless, whereas high-intensity exercise protocols may increase corticosterone levels and inhibit the beneficial effects of BDNF and neurogenesis (Cosi et al., 1993; Gould et al., 1992), basal levels of glucocorticoids are necessary to maintain neurogenesis (Sloviter et al., 1993). Soya et al. (2007) observed that low intensity exercise was capable of inducing neuronal activation (evaluated via c-fos expression) and that only this intensity of exercise could induce increases of the expression of BDNF in the hippocampus without producing increased levels of ACTH. We should mention that we have previously measured the corticosterone levels with the same protocol and found them to be increased at EX3 and EX7 (Real et al., in press). Therefore, the results for those two groups should be interpreted with caution. As reviewed by Kim and Diamond (2002), however, the hippocampus is much more sensitive to corticosterone increases than other brain regions.

Our option for short periods of exercise was based on evidence showing that for some specific processes that occur in the CNS, shorter periods of exercise induce greater changes than longer protocols. Molteni et al. (2002), for example, demonstrated that the SYN mRNA expression was increased in the hippocampus of rats submitted to 3 and 7 days of exercise, although the expression returned to basal levels after 28 days of exercise. The increase of SYN mRNA after short periods of exercise was also demonstrated by Vaynman et al. (2004). It was also observed that rats that exercised for short periods (9 days) presented increased neurogenesis and increased CREB phosphorylation (Nakagawa et al., 2002). On the other hand, glucocorticoids reduce the levels of phosphorylat- ed CREB (Yu et al., 2004), suggesting that longer periods of exercise, which are believed to be more stressful, potentially decrease the level of neurogenesis. This idea contrasts, however, with data from other studies that observed neurogenesis after longer periods of voluntary exercise in young and old mice (e.g., van Praag et al., 2005).

Berchtold et al. (2010) have suggested that the effects of exercise may depend on factors such as duration of exercise exposure, type of exercise performed and possibly other, still uncharacterized variables. In the paragraphs to follow, each brain region is discussed separately in an attempt to identify the specific effects of our exercise protocol on brain areas directly involved with the motor control. In general, our findings point to an adjustment of the CNS by the functional reorganization of the motor circuits after exercise, possibly involving synaptic and neuronal remodeling processes mediated by up- and down-regulation of protein synthesis, degradation and trafficking.

In general, we could observe that, for most regions analyzed, our exercise protocol promoted more changes for the shorter periods of exercise. This might be due to the adaptation to the protocol in late periods and/or to the novelty of the intervention in the early periods. There were, however, some mRNA changes in later periods in the striatum and motor cortex, but those changes could be compensatory changes after protein level changes at earlier periods. The main exception to this rule was the reticular formation, where we observed the most important changes after longer periods of exercise and all changes were restricted to the NFs, which we used as markers of structural plasticity and therefore more durable adaptations.

\subsection{Cerebellum}

Among the functions of the cerebellum are its participation in the somatosensory integration (Manzoni, 2007) and its signaling to the cortex about ongoing movements (Bonnefoi-Kyriacou et al., 1998). A study that observed Purkinje cells demonstrated that rats which exercised on a treadmill along their lives (from 5 to 23 months of age, twice a day for $20 \mathrm{~min}$ at $20 \mathrm{~m} / \mathrm{min}$ ) had the same number of cells as young rats, whereas rats that had aged without exercise exhibited $11 \%$ less cells and their somas were reduced by $9 \%$ (Larsen et al., 2000). An increased blood flow was also observed in the cerebellum of rats that exercised on a treadmill (Holschneider et al., 2003).

Some forms of motor learning depend on the long-term depression in the cerebellum (Ito, 1989), which usually involves modulation of AMPA-type glutamate receptors (e.g., Din et al., 2010; Matsuda et al., 2000). It was observed that treadmill exercise preserved motor coordination to some extent after transient middle cerebral artery occlusion, and enhanced $25-\mathrm{kDa}$ synaptosomal-associated protein and glial fibrillary acidic protein in the cerebellum of rats with treadmill training when compared to sedentary controls. These findings support the hypothesis of angiogenesis and remodeling of synaptic connections induced by exercise (Mizutani et al., 2010). Our results in the cerebellum showed increased protein levels of SYN and NF68, which point to a possible increase of synaptic activity and suggest that exercise might promote plasticity processes beyond long-term depression. 
There were, however, no changes of the mRNA expression of the genes studied here, suggesting that the increased protein synthesis could be due to changes of protein turnover.

\subsection{Substantia nigra}

The substantia nigra and its connections to other basal ganglia via the striatum are fundamentally important in maintaining normal movement. The increased protein levels of NF68 and NF160 at EX3 might indicate an upregulation of protein synthesis followed by remodeling after longer periods of exercise. This hypothesis is corroborated by the increased NF68 mRNA expression at EX3, even though NF160 mRNA remained unchanged. We also found an increased expression of SYN and SYP mRNAs in the substantia nigra, strongly suggesting enhanced plasticity in this region with no detectable differences of protein levels. These changes might have happened in the connections of the substantia nigra pars compacta with the striatum or the substantia nigra pars reticulata with the thalamus, superior colliculus or pedunculopontine nucleus (Paxinos, 2004). It is important to keep in mind that only some of the basal ganglia circuits have strictly motor functions, whereas others are involved in aspects of memory and cognitive functions, which may also be influenced by exercise.

\subsection{Striatum}

The striatum is responsible for motor sequence learning and automation of movement at late phases (Doyon et al., 2009; Holschneider et al., 2003, 2007). There is evidence of activation of the striatum after treadmill exercise (7 days for $20 \mathrm{~min} /$ day at $36 \mathrm{~m} / \mathrm{min}$ ), as shown by the increased expression of the Fos protein in most regions of the striatum (Liste et al., 1997). Using another exercise protocol (treadmill exercise for 2 weeks, $20 \mathrm{~min} /$ day at $60 \%$ of their maximal oxygen uptake), however, it was not possible to detect any changes in the cellular antioxidant systems nor in the levels of BDNF in the striatum and other brain regions (Cechetti et al., 2008). These studies support our hypothesis that for some systems, shorter periods of exercise induce larger adaptations, suggesting the involvement of those systems in short-term plasticity.

As seen in other regions analyzed, the striatal changes observed after short periods of exercise confirm our idea that exercise promoted plasticity in earlier periods which were followed by an adaptation to the exercise condition. We observed that the increased protein levels of SYN at EX3 and EX7 were accompanied by an increase in the SYN mRNA expression only at EX3, which might indicate that this system was already returning to basal levels at EX7 due to an adaptation to the stimulus. In face of an increased protein synthesis in earlier periods of exercise, the system may have decreased the mRNA expression to counterbalance the increased protein levels resetting the protein production to basal levels. In support of this hypothesis was the increased protein levels of SYP at EX7 followed by a decreased SYP MRNA at EX15 and increased protein levels of NF68 at EX3 followed by decreased NF68mRNA at EX7 and EX15. This increase of SYP in the striatum might have happened due to increases in glutamate release which is directly related to the phosphorylation of SYP, suggesting a possible long-term potentiation (Evans and Cousin, 2005). It is important to highlight that besides the changes of SYP mRNA expression in the substantia nigra, the striatum was the only region analyzed that showed any SYP changes. This possibly indicates that SYP may not be directly involved with the plastic mechanisms affected by the exercise protocol in other brain regions. Alternatively, the techniques employed here may not have been sensitive enough to detect SYP changes in some areas.

\subsection{Motor cortex}

We did not expect many changes in the cortical level, since treadmill exercise should be automated relatively fast and should predominantly stimulate other brain regions (Marder and Bucher, 2001). There is, however, evidence of increased blood flow in the motor and somatosensory cortex after treadmill exercise (Holschneider et al., 2003) along with increased neuronal activity in motor areas during exercise (Vissing et al., 1996). According to Holschneider and Maarek (2008), treadmill exercise increased activation of olfactory, piriform and secondary motor cortex, as well as of amygdaloid areas. This increased activation suggests that immediately following placement of the animal on the treadmill, there is increased attention being focused on olfactory novelty, its associated exploratory behavior and emotional arousal. On the other hand, possible attenuation of the activation of the motor cortex may have occurred at a later time due to habituation. Instead, we observed here a reduction of NF68 and NF160 protein levels at EX3 followed by an increase only for NF68 at EX15, which might be explained by remodeling and changes in the phosphorylation state of these proteins with no changes of mRNA expression. The functional implications of these findings are still obscure.

\subsection{Reticular formation}

The great variety of nuclei in this region (Brodal, 1981) most likely diluted any possible variation in the levels of the synaptic vesicle proteins studied here. The protein level of all the NFs, on the other hand, increased significantly at EX15. This delayed effect of exercise on this brain region is probably due to the function of some reticular formation structures in maintaining tone, balance, and posture, especially during body movements (Ángeles Fernández-Gil et al., 2010; Jahn and Zwergal, 2010). As for the mRNA expression, the effects occurred in general earlier, possibly representing an anticipatory action to prepare for the protein remodeling which followed. The NF160 mRNA increased at all exercise periods, implying that this specific reticular formation NF is more prone to be influenced by exercise. NF68 mRNA increased only at EX7.

\section{Conclusions}

The observed changes of protein levels and mRNA expression of SYN, SYP, and NFs indicate that short-term moderate physical exercise may trigger plasticity of brain regions that are related to motor function and that are often affected by neurodegenerative disorders. Identifying the mechanisms underlying the effects of a moderate intensity exercise protocol in various brain regions may be very useful in planning therapeutic 
strategies. Furthermore, we believe that changes occurring in motor regions are important to show how the effects of exercise on the CNS are diffuse and may lead to abundant plasticity and an overall healthier brain.

\section{Experimental procedures}

\subsection{Animals}

Male 2-month-old Wistar rats weighing ca. $250 \mathrm{~g}$ (obtained from the Animal Facility of the Institute of Biomedical Sciences of the University of São Paulo) were housed in groups in standard polyethylene cages with food and water ad libitum, room temperature of $23^{\circ} \mathrm{C}$ and a $12 / 12 \mathrm{~h}$ light-dark inverted cycle (Holmes et al., 2004). All protocols were approved by the Ethics Committee for Animal Research of the University of São Paulo and experimental procedures were performed in accordance with the guidelines of the Brazilian College for Animal Experimentation (COBEA) and the animal care guidelines of the National Institutes of Health (NIH).

\subsection{Exercise protocol}

The animals went through a 2-day adaptation period to a treadmill (KT 3000-IMBRAMED, adapted for rats) during which they were allowed to explore the equipment and the treadmill was turned on for $15 \mathrm{~min}(0.3$ to $0.5 \mathrm{~km} / \mathrm{h}$ ). Following the adaptation period, the animals were randomly divided in 4 groups: sedentary (S) and exercise for 3 days (EX3), 7 days (EX7) and 15 days (EX15). Each group exercised for $40 \mathrm{~min}$ a day at $10 \mathrm{~m} / \mathrm{min}$ in the middle of the active cycle (between 11am and $1 \mathrm{pm})$. The inverted cycle and this time of training were used to avoid the development of internal desynchronization, similar to night-shift workers, which was previously observed in rats that exercised during their light cycle (Salgado-Delgado et al., 2008). The animals which presented problems adapting to the treadmill or refused to run were excluded. Different groups of rats were used for immunohistochemistry, immunoblotting and real-time PCR assays.

\subsection{Immunohistochemistry}

\subsubsection{Tissue processing}

After the exercise period, the animals ( $n=8$ for each group) were deeply anesthetized (ketamine, $20 \mathrm{mg} / 100 \mathrm{~g}$ and xylazine, $2 \mathrm{mg} / 100 \mathrm{~g}$, i.m.) and perfused transcardially with $300 \mathrm{~mL}$ of $0.1 \mathrm{M}$ phosphate buffered saline (PBS) followed by $300 \mathrm{~mL}$ of $2 \%$ paraformaldehyde in $0.1 \mathrm{M}$ sodium phosphate buffer $(\mathrm{PB})$, $\mathrm{pH}$ 7.4. The brains were then removed and post-fixed for $4 \mathrm{~h}$ in the same fixative at $4{ }^{\circ} \mathrm{C}$ and cryoprotected in a $30 \%$ sucrose solution (in PB) for $48 \mathrm{~h}$. Coronal sections $(30 \mu \mathrm{m})$ were cut on dry ice using a sliding microtome. Sections were stored at $4{ }^{\circ} \mathrm{C}$ until use.

\subsubsection{Immunostaining}

Free-floating sections were stained using rabbit polyclonal antiSYN (1:1000) (Chemicon, Temecula, USA), rabbit polyclonal antiSYP (1:250) (DakoCytomation, Glostrup, Denmark) and mouse monoclonal anti-NFs (recognizing $68 \mathrm{kDa}, 160 \mathrm{kDa}$ and $200 \mathrm{kDa}$ neurofilaments) (1:2000) (Zymed Laboratories, San Francisco, CA, USA) antibodies. These antibodies have been previously tested (Kihara et al., 2008; Leonelli et al., 2009). The secondary antibodies were, respectively, biotinylated goat anti-rabbit, donkey anti-rabbit (both from Jackson Immuno Research Lab., Pennsylvania USA) and goat anti-mouse (Vector, Burlingame, CA, USA) antisera. The primary antibodies were diluted in PB with $0.3 \%$ Triton X-100 and 5\% normal goat serum (for anti-SYN and anti-NFs) or normal donkey serum (for anti-SYP) and the sections were incubated overnight (14-20 h) at room temperature (ca. $\left.24^{\circ} \mathrm{C}\right)$. After washing the sections $(3 \times 10 \mathrm{~min})$, they were incubated with the corresponding secondary antibodies, which were all diluted 1:200 in PB with 0.3\% Triton X-100 for $2 \mathrm{~h}$ at room temperature. Following additional washes $(3 \times 10 \mathrm{~min})$, the sections were incubated with an avidin-biotin-peroxidase complex (ABC Elite kit, Vector Labs., Burlingame, CA, USA) for $2 \mathrm{~h}$ at room temperature. Labeling was developed with $0.05 \%$ diaminobenzidine tetrahydrochloride (DAB) and $0.03 \%$ (final concentration) hydrogen peroxide in $\mathrm{PB}$.

After the staining procedure, the sections were mounted on glass slides and the staining was intensified with $0.05 \%$ osmium tetroxide in water. They were then dehydrated and coverslipped using Permount (Fisher, Pittsburg, PA, USA). The regions of interest were identified based on a stereotaxic atlas (Paxinos and Watson, 2005) and only subjectively analyzed.

\subsection{Western blotting}

The animals ( $n=8$ for each group) were decapitated and the regions of interest quickly collected, frozen in liquid nitrogen and stored at $-70{ }^{\circ} \mathrm{C}$ until use. The tissue was then homogenized at $4^{\circ} \mathrm{C}$ in extraction buffer (Tris, pH 7.4, 100 mM; EDTA 10 mM; PMSF $2 \mathrm{mM}$; aprotinin $0.01 \mathrm{mg} / \mathrm{ml}$ ). The homogenates were centrifuged at $12,000 \mathrm{rpm}$ at $4{ }^{\circ} \mathrm{C}$ for $20 \mathrm{~min}$, and the protein concentration of the supernatant was determined using a protein assay kit (BioRad, Hercules, CA, USA) (Bradford, 1976). The material was stored in sample buffer (Tris/HCl 125 mM, pH 6.8; 2.5\% (p/v) SDS; 2.5\% 2mercaptoethanol, $4 \mathrm{mM}$ EDTA and $0.05 \%$ bromofenol blue) (Laemmli, 1970) at $-70{ }^{\circ} \mathrm{C}$ until starting the assays. Seventy-five to $100 \mu$ g of total proteins in Laemmli buffer were boiled for $5 \mathrm{~min}$ and separated by $6.5 \%$ and $8 \%$ acrylamide SDS gels (Bio-Rad, USA) at $25 \mathrm{~mA}$ (Laemmli, 1970) and electrophoretically transferred to nitrocellulose membranes (Millipore) at $100 \mathrm{~V}$ for 80 min using a Trans-Blot cell system (Bio-Rad, USA). The membranes were then blocked for $2 \mathrm{~h}$ at room temperature with phosphate-buffered saline (PBS) containing 0.05\% Tween-20 (TTBS) and 5\% non-fat milk, and incubated overnight at $4{ }^{\circ} \mathrm{C}$ with the same primary antibodies used for immunohistochemistry at a concentration of 1:1000. The membranes were then incubated for $2 \mathrm{~h}$ with antirabbit-HRP IgG for SYN and SYP and anti-mouse-HRP IgG for NFs (Amersham, Little Chalfont, Buckinghamshire, UK) diluted 1:10,000 in TTBS with $1 \%$ non-fat milk. The probed proteins were developed by using a chemiluminescent kit (ECL, Amersham Biosciences, NJ, EUA). The membrane was then incubated for $30 \mathrm{~min}$ at room temperature with stripping buffer and an anti$\beta$-actin antibody (Sigma, St. Louis, MO) was used to quantify $\beta$ actin as a loading control. The bound antibodies were visualized using radiographic films which were placed in contact with the membranes, then developed and fixed. The quantification of 
band intensity was performed with Scion Image 4.0.2 (Scion Corporation, Frederick, MD).

\subsection{RNA isolation, cDNA synthesis and real-time PCR}

Tissue from the brain regions of interest were collected $(n=8$ for each group) and directly homogenized in $1 \mathrm{~mL}$ TRIzol (Invitrogen, Carlsbad, CA, USA) with a homogenizer and total RNA was isolated following the manufacturer's suggested protocol. Briefly, following one chloroform extraction step, RNA was precipitated with isopropanol and the pellet washed once in $70 \%$ ethanol. After air-drying, RNA was resuspended in DEPC-treated water and the concentration of each sample obtained from A260/ A280 nm measurements. Residual DNA was removed using DNase I (Invitrogen) by following the manufacturer's protocol. For each $20 \mu \mathrm{L}$ reverse transcription reaction, $4 \mu \mathrm{g}$ total RNA was mixed with $1 \mu \mathrm{L}$ oligodT primer $(0.5 \mu \mathrm{g} / \mu \mathrm{L}$; Invitrogen) and incubated for $10 \mathrm{~min}$ at $65^{\circ} \mathrm{C}$. After cooling on ice the solution was mixed with $4 \mu \mathrm{L} 5 \times$ first strand buffer, $2 \mu \mathrm{L}$ of $0.1 \mathrm{M} \mathrm{DTT}, 1 \mu \mathrm{L}$ of dATP, dTTP, dCTP and dGTP (10 mM each), and $1 \mu \mathrm{L}$ SuperScript III reverse transcriptase (200 U/ $\mu \mathrm{L}$; Invitrogen) and incubated for $60 \mathrm{~min}$ at $50^{\circ} \mathrm{C}$. Reaction was inactivated by heating at $70{ }^{\circ} \mathrm{C}$ for $15 \mathrm{~min}$, and the samples were diluted four times.

The real-time PCR reaction system included the following: 200 to $400 \mathrm{nM}$ primers, 5 ng cDNA samples, and 1X SYBR® Green PCR Master Mix (Applied Biosystems, Foster City, CA, USA). Using the Rotor-Gene 3000 Real-time PCR detection system (Corbett Research, Mortlake, NSW, Australia), PCR cycling conditions were set as follows: after initial activation at $50^{\circ} \mathrm{C}$ for $2 \mathrm{~min}$ and $95^{\circ} \mathrm{C}$ for $10 \mathrm{~min}, 40$ cycles of $95^{\circ} \mathrm{C}$ for $15 \mathrm{~s}$ and $60^{\circ} \mathrm{C}$ for $1 \mathrm{~min}$, then melt curve analysis was performed by heating samples from $65^{\circ} \mathrm{C}$ to $99^{\circ} \mathrm{C}\left(1^{\circ} \mathrm{C}\right.$ increment changes at $5 \mathrm{~s}$ intervals), in order to evaluate primer specificity. All sample measurements were performed in duplicate. Primers for the housekeeping genes were obtained from Depreter et al. (2002) and the primers for the genes of interest were designed using software primer express v3.0 (Applied Biosystems). The properties of the primers used are presented in Table 2 .

Relative quantification of target gene expression was performed using the comparative CT method as described in detail elsewhere (Medhurst et al., 2000). The dCT value was determined by subtracting the target CT of each sample from the respective hydroxymethylbilane synthase (HMBS) and hypoxanthine phosphoribosyltransferase 1 (HPRT1) mean values which were used as housekeeping genes. Calculation of ddCT involved the sedentary group mean dCT value as an arbitrary constant to subtract from all other $\mathrm{dCT}$ mean values. Fold-changes in gene expression of the target gene are equivalent to $2^{-\Delta \Delta C T}$.

\subsection{Statistical analysis}

Data are expressed as the mean \pm SEM. Statistical analyses were performed using one-way ANOVA with Tukey post hoc test for Western blotting and mRNA expression data.

\section{Acknowledgments}

This study was supported by FAPESP and CNPq (Brazil). The authors would like to thank Drs. Andréa S. Torrão, Rui Curi and Rhowena J. B. Matos for their helpful suggestions and support. A.F.B.F., C.C.R. and A.C.R. are the recipients of fellowships from FAPESP.

\section{REF ERENCES}

Ángeles Fernández-Gil, M., Palacios-Bote, R., Leo-Barahona, M., Mora-Encinas, J.P., 2010. Anatomy of the brainstem: a gaze into the stem of life. Semin. Ultrasound CT MR 31, 196-219.

Arida, R.M., Scorza, C.A., da Silva, A.V., Scorza, F.A., Cavalheiro, E.A., 2004. Differential effects of spontaneous versus forced exercise in rats on the staining of parvalbumin-positive neurons in the hippocampal formation. Neurosci. Lett. 364, 135-138.

Arida, R.M., Scorza, C.A., Scorza, F.A., Gomes da Silva, S., da Graca Naffah-Mazzacoratti, M., Cavalheiro, E.A., 2007. Effects of different types of physical exercise on the staining of parvalbumin-positive neurons in the hippocampal formation of rats with epilepsy. Prog. Neuropsychopharmacol. Biol. Psychiatry $31,814-822$

Table 2 - Description of primers used to study the genes of interest and the housekeeping genes*.

\begin{tabular}{|c|c|c|c|c|}
\hline Gene & Refseq & Primers sequence $\left(5^{\prime}\right.$ to $\left.3^{\prime}\right)$ & Amplicon length (bp) & Primer Efficiency \\
\hline NF68 & NM_031783.1 & $\begin{array}{l}\text { FW: AGA CAT CAG CGC CAT GCA } \\
\text { RV:TTC GTG CTT CGC AGC TCA T }\end{array}$ & 60 & 2.06 \\
\hline NF160 & NM_017029.1 & $\begin{array}{l}\text { FW: GGC TCC AGA CAT TGT ATT TTC CTT } \\
\text { RV: GGC ACC CTG AGC TTG CAT }\end{array}$ & 63 & 2.00 \\
\hline NF200 & NM_012607.2 & $\begin{array}{l}\text { FW: AGA GGA GTG GTT CCG AGT GAG A } \\
\text { RV: GCG CAT AGC ATC CGT GTT C }\end{array}$ & 70 & 1.98 \\
\hline SYN & NM_001110782.1 and NM_019137.1 & $\begin{array}{l}\text { FW: TTC AGC ATG GCA CGT AAT GG } \\
\text { RV: CCA GCA TAC TGC AGC CCA AT }\end{array}$ & 59 & 2.03 \\
\hline SYP & NM_012664.1 & $\begin{array}{l}\text { FW: CCC TTC AGG CTG CAC CAA } \\
\text { RV: TTG GTA GTG CCC CCT TTG AC }\end{array}$ & 62 & 2.18 \\
\hline HMBS* $^{*}$ & NM_013168 & $\begin{array}{l}\text { FW: TCT AGA TGG CTC AGA TAG CAT GCA } \\
\text { RV: TGG ACC ATC TTC TTG CTG AAC A }\end{array}$ & 76 & 2.09 \\
\hline HPRT1* & X62085 & $\begin{array}{l}\text { FW: GCG AAA GTG GAA AAG CCA AGT } \\
\text { RV: GCC ACA TCA ACA GGA CTC TTG TAG }\end{array}$ & 76 & 2.01 \\
\hline
\end{tabular}

NF68: neurofilament 68 kDa; NF160: neurofilament 160 kDa; NF200: neurofilament $200 \mathrm{kDa}$; SYN: synapsin I; SYP: synaptophysin; HMBS hydroxymethylbilane synthase; HPRT1: hypoxanthine phosphoribosyltransferase 1. 
Berchtold, N.C., Castello, N., Cotman, C.W., 2010. Exercise and time-dependent benefits to learning and memory. Neuroscience 167, 588-597.

Bonnefoi-Kyriacou, B., Legallet, E., Lee, R.G., Trouche, E., 1998. Spatio-temporal and kinematic analysis of pointing movements performed by cerebellar patients with limb ataxia. Exp. Brain Res. 119, 460-466.

Bradford, M.M., 1976. A rapid and sensitive method for the quantitation of microgram quantities of protein utilizing the principle of protein-dye binding. Anal. Biochem. 72, 248-254.

Brodal, A., 1981. Neurological Anatomy, In relation to Clinical Medicine, Third Ed. Oxford University Press, New York.

Cechetti, F., Fochesatto, C., Scopel, D., Nardin, P., Goncalves, C.A., Netto, C.A., Siqueira, I.R., 2008. Effect of a neuroprotective exercise protocol on oxidative state and BDNF levels in the rat hippocampus. Brain Res. 1188, 182-188.

Cesca, F., Baldelli, P., Valtorta, F., Benfenati, F., 2010. The synapsins: Key actors of synapse function and plasticity. Prog. Neurobiol. 91, 313-348.

Cosi, C., Spoerri, P.E., Comelli, M.C., Guidolin, D., Skaper, S.D., 1993. Glucocorticoids depress activity-dependent expression of BDNF mRNA in hippocampal neurones. Neuroreport 4, 527-530.

Cotman, C.W., Berchtold, N.C., 2002. Exercise: a behavioral intervention to enhance brain health and plasticity. Trends Neurosci. 25, 295-301.

Depreter, M., Vandesompele, J., Espeel, M., Speleman, F., Roels, F., 2002. Modulation of the peroxisomal gene expression pattern by dehydroepiandrosterone and vitamin $\mathrm{D}$ : therapeutic implications. J. Endocrinol. 175, 779-792.

Din, N., Ahmad, I., Ul Haq, I., Elahi, S., Hoessli, D.C., Shakoori, A.R., 2010. The function of GluR1 and GluR2 in cerebellar and hippocampal LTP and LTD is regulated by interplay of phosphorylation and O-GlcNAc modification. J. Cell. Biochem. 109, 585-597.

Dishman, R.K., Berthoud, H.R., Booth, F.W., Cotman, C.W., Edgerton, V.R., Fleshner, M.R., Gandevia, S.C., Gomez-Pinilla, F., Greenwood, B.N., Hillman, C.H., Kramer, A.F., Levin, B.E., Moran, T.H., Russo-Neustadt, A.A., Salamone, J.D., Van Hoomissen, J.D., Wade, C.E., York, D.A., Zigmond, M.J., 2006. Neurobiology of exercise. Obesity (Silver Spring) 14, 345-356.

Doyon, J., Bellec, P., Amsel, R., Penhune, V., Monchi, O., Carrier, J., Lehericy, S., Benali, H., 2009. Contributions of the basal ganglia and functionally related brain structures to motor learning. Behav. Brain Res. 199, 61-75.

Dustman, R.E., Emmerson, R.Y., Ruhling, R.O., Shearer, D.E., Steinhaus, L.A., Johnson, S.C., Bonekat, H.W., Shigeoka, J.W., 1990. Age and fitness effects on EEG, ERPs, visual sensitivity, and cognition. Neurobiol. Aging 11, 193-200.

Eadie, B.D., Redila, V.A., Christie, B.R., 2005. Voluntary exercise alters the cytoarchitecture of the adult dentate gyrus by increasing cellular proliferation, dendritic complexity, and spine density. J. Comp. Neurol. 486, 39-47.

Edgerton, V.R., Tillakaratne, N.J., Bigbee, A.J., de Leon, R.D., Roy, R.R., 2004. Plasticity of the spinal neural circuitry after injury. Annu. Rev. Neurosci. 27, 145-167.

Evans, G.J.O., Cousin, M.A., 2005. Tyrosine phosphorylation of synaptophysin in synaptic vesicle recycling. Biochem. Soc. Trans. 33, 1350-1353.

Felix, J.V., Michelini, L.C., 2007. Training-induced pressure fall in spontaneously hypertensive rats is associated with reduced angiotensinogen mRNA expression within the nucleus tractus solitarii. Hypertension 50, 780-785.

Ferrer-Alcon, M., Winkler-Hirt, C., Madani, R., Perrin, F.E., Kato, A.C., 2008. Low intensity exercise attenuates disease progression and stimulates cell proliferation in the spinal cord of a mouse model with progressive motor neuronopathy. Neuroscience 152, 291-295.
Florence, S.L., Taub, H.B., Kaas, J.H., 1998. Large-scale sprouting of cortical connections after peripheral injury in adult macaque monkeys. Science 282, 1117-1121.

Gentile, A.M., Beheshti, Z., Held, J.M., 1987. Enrichment versus exercise effects on motor impairments following cortical removals in rats. Behav. Neural Biol. 47, 321-332.

Gomez-Pinilla, F., Ying, Z., Roy, R.R., Molteni, R., Edgerton, V.R., 2002. Voluntary exercise induces a BDNF-mediated mechanism that promotes neuroplasticity. J. Neurophysiol. 88, 2187-2195.

Gould, E., Cameron, H.A., Daniels, D.C., Woolley, C.S., McEwen, B.S., 1992. Adrenal hormones suppress cell division in the adult rat dentate gyrus. J. Neurosci. 12, 3642-3650.

Grealy, M.A., Johnson, D.A., Rushton, S.K., 1999. Improving cognitive function after brain injury: the use of exercise and virtual reality. Arch. Phys. Med. Rehabil. 80, 661-667.

Hillman, C.H., Erickson, K.I., Kramer, A.F., 2008. Be smart, exercise your heart: exercise effects on brain and cognition. Nat. Rev. Neurosci. 9, 58-65.

Hirokawa, N., 1991. Molecular architecture and dynamics of the neuronal cytoskeleton. In: Burgoyne, R.D. (Ed.), The neuronal cytoskeleton. Wiley, New York, pp. 5-74.

Holmes, M.M., Galea, L.A., Mistlberger, R.E., Kempermann, G., 2004. Adult hippocampal neurogenesis and voluntary running activity: circadian and dose-dependent effects. J. Neurosci. Res. 76, 216-222.

Holschneider, D.P., Maarek, J.-M.I., 2008. Brain maps on the go: functional imaging during motor challenge. Methods 45 , 255-261.

Holschneider, D.P., Maarek, J.M., Yang, J., Harimoto, J., Scremin, O.U., 2003. Functional brain mapping in freely moving rats during treadmill walking. J. Cereb. Blood Flow Metab. 23, 925-932.

Holschneider, D.P., Yang, J., Guo, Y., Maarek, J.M., 2007. Reorganization of functional brain maps after exercise training: importance of cerebellar-thalamic-cortical pathway. Brain Res. 1184, 96-107.

Isaacs, K.R., Anderson, B.J., Alcantara, A.A., Black, J.E., Greenough, W.T., 1992. Exercise and the brain: angiogenesis in the adult rat cerebellum after vigorous physical activity and motor skill learning. J. Cereb. Blood Flow Metab. 12, 110-119.

Ito, M., 1989. Long-term depression. Annu. Rev. Neurosci. 12, 85-102.

Jahn, K., Zwergal, A., 2010. Imaging supraspinal locomotor control in balance disorders. Restor. Neurol. Neurosci. 28, 105-114.

Kihara, A.H., Santos, T.O., Paschon, V., Matos, R.J., Britto, L.R., 2008. Lack of photoreceptor signaling alters the expression of specific synaptic proteins in the retina. Neuroscience 151, 995-1005.

Kilgard, M.P., Merzenich, M.M., 1998. Cortical map reorganization enabled by nucleus basalis activity. Science 279, 1714-1718.

Kim, J.J., Diamond, D.M., 2002. The stressed hippocampus, synaptic plasticity and lost memories. Nat. Rev. Neurosci. 3, 453-462.

Kleim, J.A., Barbay, S., Cooper, N.R., Hogg, T.M., Reidel, C.N., Remple, M.S., Nudo, R.J., 2002. Motor learning-dependent synaptogenesis is localized to functionally reorganized motor cortex. Neurobiol. Learn. Mem. 77, 63-77.

Kramer, A.F., Hahn, S., Cohen, N.J., Banich, M.T., McAuley, E., Harrison, C.R., Chason, J., Vakil, E., Bardell, L., Boileau, R.A., Colcombe, A., 1999. Ageing, fitness and neurocognitive function. Nature 400, 418-419.

Laemmli, U.K., 1970. Cleavage of structural proteins during the assembly of the head of bacteriophage T4. Nature 227, 680-685.

Lambert, T.J., Fernandez, S.M., Frick, K.M., 2005. Different types of environmental enrichment have discrepant effects on spatial memory and synaptophysin levels in female mice. Neurobiol. Learn. Mem. 83, 206-216. 
Larsen, J.O., Skalicky, M., Viidik, A., 2000. Does long-term physical exercise counteract age-related Purkinje cell loss? A stereological study of rat cerebellum. J. Comp. Neurol. 428, 213-222.

Laurin, D., Verreault, R., Lindsay, J., MacPherson, K., Rockwood, K. 2001. Physical activity and risk of cognitive impairment and dementia in elderly persons. Arch. Neurol. 58, 498-504.

Leonelli, M., Martins, D.O., Kihara, A.H., Britto, L.R., 2009. Ontogenetic expression of the vanilloid receptors TRPV1 and TRPV2 in the rat retina. Int. J. Dev. Neurosci. 27, 709-718.

Liste, I., Guerra, M.J., Caruncho, H.J., Labandeira-Garcia, J.L., 1997. Treadmill running induces striatal Fos expression via NMDA glutamate and dopamine receptors. Exp. Brain Res. 115, 458-468.

Lui, A.J., Byl, N.N., 2009. A systematic review of the effect of moderate intensity exercise on function and disease progression in amyotrophic lateral sclerosis. J. Neurol. Phys. Ther. 33, 68-87.

Lupinacci, N.S., Rikli, R.E., Jones, C.J., Ross, D., 1993. Age and physical activity effects on reaction time and digit symbol substitution performance in cognitively active adults. Res. Q. Exerc. Sport 64, 144-150.

Manzoni, D., 2007. The cerebellum and sensorimotor coupling: looking at the problem from the perspective of vestibular reflexes. Cerebellum 6, 24-37.

Marder, E., Bucher, D., 2001. Central pattern generators and the control of rhythmic movements. Curr. Biol. 11, 986-996.

Marin, R., Williams, A., Hale, S., Burge, B., Mense, M., Bauman, R., Tortella, F., 2003. The effect of voluntary exercise exposure on histological and neurobehavioral outcomes after ischemic brain injury in the rat. Physiol. Behav. 80, 167-175.

Matsuda, S., Launey, T., Mikawa, S., Hirai, H., 2000. Disruption of AMPA receptor GluR2 clusters following long-term depression induction in cerebellar Purkinje neurons. EMBO J. 19, 2765-2774.

Mattson, M.P., 2000. Neuroprotective signaling and the aging brain: take away my food and let me run. Brain Res. 886, 47-53.

Medhurst, A.D., Harrison, D.C., Read, S.J., Campbell, C.A., Robbins, M.J., Pangalos, M.N., 2000. The use of TaqMan RT-PCR assays for semiquantitative analysis of gene expression in CNS tissues and disease models. J. Neurosci. Methods 98, 9-20.

Mirochnic, S., Wolf, S., Staufenbiel, M., Kempermann, G., 2009. Age effects on the regulation of adult hippocampal neurogenesis by physical activity and environmental enrichment in the APP23 mouse model of Alzheimer disease. Hippocampus 19, 1008-1018.

Mizutani, K., Sonoda, S., Hayashi, N., Takasaki, A., Beppu, H., Saitoh, E., Shimpo, K., 2010. Analysis of protein expression profile in the cerebellum of cerebral infarction rats after treadmill training. Am. J. Phys. Med. Rehabil. 89, 107-114.

Molteni, R., Ying, Z., Gomez-Pinilla, F., 2002. Differential effects of acute and chronic exercise on plasticity-related genes in the rat hippocampus revealed by microarray. Eur. J. Neurosci. 16, 1107-1116.

Molteni, R., Zheng, J.Q., Ying, Z., Gomez-Pinilla, F., Twiss, J.L., 2004. Voluntary exercise increases axonal regeneration from sensory neurons. Proc. Natl. Acad. Sci. U. S. A. 101, 8473-8478.

Nakagawa, S., Kim, J.E., Lee, R., Malberg, J.E., Chen, J., Steffen, C., Zhang, Y.J., Nestler, E.J., Duman, R.S., 2002. Regulation of neurogenesis in adult mouse hippocampus by cAMP and the cAMP response element-binding protein. J. Neurosci. 22, 3673-3682.

Neeper, S.A., Gomez-Pinilla, F., Choi, J., Cotman, C., 1995. Exercise and brain neurotrophins. Nature 373, 109.

Nudo, R.J., Milliken, G.W., Jenkins, W.M., Merzenich, M.M., 1996 Use-dependent alterations of movement representations in primary motor cortex of adult squirrel monkeys. J. Neurosci. 16, 785-807.

Paxinos, G., 2004. The Rat Nervous System, Third Ed. Elsevier Academic Press, Amsterdam.
Paxinos, G., Watson, C., 2005. The rat brain - in stereotaxic coordinates, Fifth Ed. Elsevier Academic Press, Burlington.

Ploughman, M., Granter-Button, S., Chernenko, G., Tucker, B.A., Mearow, K.M., Corbett, D., 2005. Endurance exercise regimens induce differential effects on brain-derived neurotrophic factor, synapsin-I and insulin-like growth factor I after focal ischemia. Neuroscience 136, 991-1001.

Pons, T.P., Garraghty, P.E., Ommaya, A.K., Kaas, J.H., Taub, E., Mishkin, M., 1991. Massive cortical reorganization after sensory deafferentation in adult macaques. Science 252, 1857-1860.

Real, C.C., Ferreira, A.F., Hernandes, M.S., Britto, L.R., Pires, R.S. in press. Exercise-induced plasticity of AMPA-type glutamate receptor subunits in the rat brain. Brain Res. doi:10.1016/j. brainres.2010.09.060.

Redila, V.A., Christie, B.R., 2006. Exercise-induced changes in dendritic structure and complexity in the adult hippocampal dentate gyrus. Neuroscience 137, 1299-1307.

Redila, V.A., Olson, A.K., Swann, S.E., Mohades, G., Webber, A.J., Weinberg, J., Christie, B.R., 2006. Hippocampal cell proliferation is reduced following prenatal ethanol exposure but can be rescued with voluntary exercise. Hippocampus 16, 305-311.

Ridgel, A.L., Vitek, J.L., Alberts, J.L., 2009. Forced, not voluntary, exercise improves motor function in Parkinson's disease patients. Neurorehabil. Neural Repair 23, 600-608.

Sadowsky, C.L., McDonald, J.W., 2009. Activity-based restorative therapies: concepts and applications in spinal cord injury-related neurorehabilitation. Dev. Disabil. Res. Rev. 15, 112-116.

Salgado-Delgado, R., Angeles-Castellanos, M., Buijs, M.R., Escobar, C., 2008. Internal desynchronization in a model of night-work by forced activity in rats. Neuroscience 154, 922-931.

Sanes, J.N., Donoghue, J.P., 2000. Plasticity and primary motor cortex. Annu. Rev. Neurosci. 23, 393-415.

Sloviter, R.S., Dean, E., Neubort, S., 1993. Electron microscopic analysis of adrenalectomy-induced hippocampal granule cell degeneration in the rat: apoptosis in the adult central nervous system. J. Comp. Neurol. 330, 337-351.

Smith, A.D., Zigmond, M.J., 2003. Can the brain be protected through exercise? Lessons from an animal model of parkinsonism. Exp. Neurol. 184, 31-39.

Soya, H., Nakamura, T., Deocaris, C.C., Kimpara, A., Iimura, M., Fujikawa, T., Chang, H., McEwen, B.S., Nishijima, T., 2007. BDNF induction with mild exercise in the rat hippocampus. Biochem. Biophys. Res. Commun. 358, 961-967.

Stummer, W., Weber, K., Tranmer, B., Baethmann, A., Kempski, O. 1994. Reduced mortality and brain damage after locomotor activity in gerbil forebrain ischemia. Stroke 25, 1862-1869.

Timofeeva, E., Huang, Q., Richard, D., 2003. Effects of treadmill running on brain activation and the corticotropin-releasing hormone system. Neuroendocrinology 77, 388-405.

van Praag, H., Christie, B.R., Sejnowski, T.J., Gage, F.H., 1999. Running enhances neurogenesis, learning, and long-term potentiation in mice. Proc. Natl. Acad. Sci. U. S. A. 96, 13427-13431.

van Praag, H., Schinder, A.F., Christie, B.R., Toni, N., Palmer, T.D. Gage, F.H., 2002. Functional neurogenesis in the adult hippocampus. Nature 415, 1030-1034.

van Praag, H., Shubert, T., Zhao, C., Gage, F.H., 2005. Exercise enhances learning and hippocampal neurogenesis in aged mice. J. Neurosci. 25, 8680-8685.

Vaynman, S., Ying, Z., Gomez-Pinilla, F., 2004. Hippocampal BDNF mediates the efficacy of exercise on synaptic plasticity and cognition. Eur. J. Neurosci. 20, 2580-2590.

Vissing, J., Andersen, M., Diemer, N.H., 1996. Exercise-induced changes in local cerebral glucose utilization in the rat. J. Cereb. Blood Flow Metab. 16, 729-736.

Winter, B., Breitenstein, C., Mooren, F.C., Voelker, K., Fobker, M., Lechtermann, A., Krueger, K., Fromme, A., Korsukewitz, C., Floel, A., Knecht, S., 2007. High impact running improves learning. Neurobiol. Learn. Mem. 87, 597-609. 
Xerri, C., Merzenich, M.M., Peterson, B.E., Jenkins, W., 1998. Plasticity of primary somatosensory cortex paralleling sensorimotor skill recovery from stroke in adult monkeys. J. Neurophysiol. 79, 2119-2148.

Ying, Z., Roy, R.R., Edgerton, V.R., Gomez-Pinilla, F., 2005. Exercise restores levels of neurotrophins and synaptic plasticity following spinal cord injury. Exp. Neurol. 193, 411-419.
Yu, I.T., Lee, S.H., Lee, Y.S., Son, H., 2004. Differential effects of corticosterone and dexamethasone on hippocampal neurogenesis in vitro. Biochem. Biophys. Res. Commun. 317, 484-490.

Yuan, A., Sasaki, T., Rao, M.V., Kumar, A., Kanumuri, V., Dunlop, D.S., Liem, R.K., Nixon, R.A., 2009. Neurofilaments form a highly stable stationary cytoskeleton after reaching a critical level in axons. J. Neurosci. 29, 11316-11329. 


\section{ANEXO B - Artigo Submetido}

Ferreira AF, Real CC, Rodrigues AC, Alves AS, Britto LR. Short-term, moderate exercise is capable of inducing BDNF-independent hippocampal plasticity. 


\section{SHORT-TERM, MODERATE EXERCISE IS CAPABLE OF INDUCING BDNF-INDEPENDENT HIPPOCAMPAL PLASTICITY}

Ana F. B. Ferreira ${ }^{1}$, Caroline C. Real ${ }^{1}$, Alice C. Rodrigues ${ }^{2}$, Adilson S. Alves ${ }^{1}$, Luiz R. G. Britto ${ }^{1}$

${ }^{1}$ Department of Physiology and Biophysics, Institute of Biomedical Sciences, University of São Paulo, São Paulo, SP, Brazil; ${ }^{2}$ Department of Clinical and Toxicological Analysis, Faculty of Pharmaceutical Sciences, University of São Paulo, São Paulo, SP, Brazil.

\section{ABSTRACT}

Exercise is known to improve cognitive functions and to induce neuroprotection, and at least part of these functions rely on the induction of structural changes such as synaptogenesis and neurogenesis. In this study we used a short-term, moderate intensity treadmill exercise protocol to investigate the effects of exercise on usual markers of hippocampal synaptic and structural plasticity, such as synapsin I (SYN), synaptophysin (SYP), neurofilaments (NF), microtubule-associated protein 2 (MAP2), glutamate receptor subunits GluR1 and GluR2/3, brain-derived neurotrophic factor (BDNF) and glial fibrillary acidic protein (GFAP). Immunohistochemistry, Western Blotting and real-time PCR were used. We also evaluated the number of cells positive for the neurogenesis marker 5-bromo2-deoxyuridine (BrdU) and the plasma corticosterone levels. Adult male Wistar rats were adapted to a treadmill and divided into 4 groups: sedentary (S), 3-day exercise (EX3), 7-day exercise (EX7) and 15-day exercise (EX15). The protein changes detected were increased levels of NF68 and MAP2 at EX3, of SYN at EX7 and of GFAP at EX15, accompanied by a decreased level of GluR1 at EX3. The real-time PCR analysis disclosed only an increase of MAP2 mRNA at EX7. We also observed a 2-fold increase of the number of BrdU-positive cells in the dentate gyrus at EX3 and increased corticosterone levels at EX3 and EX7. These results reveal a positive effect of short-term, moderate treadmill exercise on hippocampal plasticity. This effect was in general independent of transcriptional processes and of BDNF upregulation, and occurred even in the presence of increased corticosterone levels.

Keywords: physical exercise; synaptic plasticity; structural plasticity; neurogenesis; BDNF; corticosterone. 


\section{ANEXO C - Artigo em fase de preparação}

Ferreira AF, Britto LR, Filosa JA. Effects of exercise on calcium dynamics of the astrocytic endothelin system and structure of the neurovascular unit. 


\title{
EFFECTS OF EXERCISE ON CALCIUM DYNAMICS OF THE ASTROCYTIC ENDOTHELIN SYSTEM AND STRUCTURE OF THE NEUROVASCULAR UNIT
}

\author{
Ana F. B. Ferreira ${ }^{1,2}$, Luiz R. G. Britto ${ }^{1}$, Jessica A. Filosa ${ }^{2}$ \\ ${ }^{1}$ Department of Physiology and Biophysics, Institute of Biomedical Sciences, \\ University of São Paulo, São Paulo, SP, Brazil; '2Department of Physiology, Medical \\ College of Georgia, Augusta, GA, USA.
}

\begin{abstract}
Evidence shows that physical exercise is neuroprotective and enhances brain function. Exercise has also been associated with structural changes such as angiogenesis, synaptogenesis and neurogenesis. The aim of this study was to determine if a short-term exercise protocol alters $\mathrm{Ca}^{2+}$ dynamics in astrocytes, along with the structure and protein levels of constituents of the neurovascular unit (NVU). Given the multiplicity of functions of endothelin (ET) in the brain, including neurotransmission, neuromodulation and angiogenesis, among others, we evaluated the actions of this peptide in the NVU. 3 groups of adult male Wistar rats were subjected to treadmill exercise $(45 \mathrm{~min} /$ day, at $0.6 \mathrm{~km} / \mathrm{h}$ for 2 weeks, 5 days/week), by the end of which they were $42-46$ days old. Confocal $\mathrm{Ca}^{2+}$ imaging was performed in $200 \mu \mathrm{m}$-cortical slices loaded ( $2 \mathrm{hs}$ ) with $10 \mathrm{mM}$ Fluo-4 AM. Slices were excited with a solid-state laser at $488 \mathrm{~nm}$ and emitted light was collected at $>495 \mathrm{~nm}$. Images were acquired at 1 frame/s with an EMCCD camera. All experiments were performed at 33$35 \stackrel{\circ}{\circ}$. FITC-Dextran injections $(50 \mathrm{mg} / \mathrm{mL}, 8$ minutes) were performed into the left jugular vein and immunohistochemistry was performed by using an antibody against the astrocytic glial fibrillary acidic protein (GFAP) (1:10k) and the nuclear marker TOTO (1:10k). Western Blotting was conducted using antibodies against GFAP (1:10k) and endothelin B receptors $\left(E T_{B} R\right)(1: 4 k)$. Endothelin-induced $\mathrm{Ca}^{2+}$ changes in astrocytes were observed in the form of sustained and oscillatory increases, with predominant activity (> 90\%) in the form of sustained increase. Both $\mathrm{ET}_{A} R$ and $\mathrm{ET}_{\mathrm{B}} \mathrm{R}$ activities were evaluated using $\mathrm{ET}-1, \mathrm{ET}-3$ and the specific $E T_{B} R$ agonist sarafotoxin S6c. We observed that after exercise more cells responded to S6c and their responses had a steeper rise, a higher peak amplitude and the $\mathrm{Ca}^{2+}$ increase was more sustained $(p<0.001)$. On the other hand, the responses to ET-1 were delayed after exercise $(p<0.05)$. We also observed significant vascular density and GFAP density changes in most of the cortical layers analyzed. The immunoblotting analysis of $E T_{B} R$ and GFAP, however, showed no differences between the exercised and sedentary groups. These results suggest that short-term physical exercise alters astrocytic structural proteins and function in the motor cortex, increasing the responsiveness of astrocytic activity to S6c, likely via the activation of the $\mathrm{ET}_{\mathrm{B}} \mathrm{R}$ subtype. Exercise also appears to decrease the responsiveness to $E T-1$, likely via the down-regulation of the $E T_{A} R$ subtype.
\end{abstract}

Key-words: Exercise; Motor cortex; Astrocytes; Intracellular calcium signaling; Endothelins. 